\title{
REDUCTION OF ATMOSPHERIC POLLUTION
}

BY THE APPLICATION OF

FLUIDIZED-BED COMBUSTION

AND REGENERATION OF

SULFUR-CONTAINING ADDITIVES

\author{
Annual Report \\ July 1973 -June 1974
}

by

G. J. Vogel, W. M. Swift, J. F. Lenc,

P. T. Cunningham, W. I. Wilson, A. F. Panek,

F. G. Teats, and A. A. Jonke

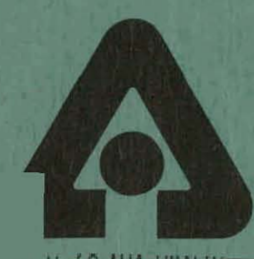




\section{DISCLAIMER}

This report was prepared as an account of work sponsored by an agency of the United States Government. Neither the United States Government nor any agency Thereof, nor any of their employees, makes any warranty, express or implied, or assumes any legal liability or responsibility for the accuracy, completeness, or usefulness of any information, apparatus, product, or process disclosed, or represents that its use would not infringe privately owned rights. Reference herein to any specific commercial product, process, or service by trade name, trademark, manufacturer, or otherwise does not necessarily constitute or imply its endorsement, recommendation, or favoring by the United States Government or any agency thereof. The views and opinions of authors expressed herein do not necessarily state or reflect those of the United States Government or any agency thereof. 


\section{DISCLAIMER}

Portions of this document may be illegible in electronic image products. Images are produced from the best available original document. 
The facilities of Argonne National Laboratory are owned by the United States Government. Under the terms of a contract (W-31-109-Eng-38) between the U. S. Atomic Energy Commission, Argonne Universities Association and The University of Chicago, the University employs the staff and operates the Laboratory in accordancewith policies and programs formulated, approved and reviewed by the Association.

\section{MEMBERS OF ARGONNE UNIVERSITIES ASSOCIATION}

The University of Arizona Carnegie-Mellon University Case Western Reserve University The University of Chicago University of Cincinnati Illinois Institute of Technology University of Illinois Indiana University Iowa State University The University of Iowa
Kansas State University The University of Kansas Loyola University Marquette University Michigan State University The University of Michigan University of Minnesota University of Missouri Northwestern University University of Notre Dame
The Ohio State University Ohio University The Pennsylvania State University Purdue University

Saint Louis University Southern Illinois University The University of Texas at Austin Washington University Wayne State University The University of Wisconsin

\section{NOTICE}

This report was prepared as an account of work sponsored by the United States Government. Neither the United States nor the United States Atomic Energy Commission, nor any of their employees, nor any of their contractors, subcontractors, or their employees, makes any warranty, express or implied, or assumes any legal liability or responsibility for the accuracy, completeness or usefulness of any information, apparatus, product or process disclosed, or represents that its use would not infringe privately-owned rights.

Printed in the United States of America

Available from

National Technical Information Service

U.S. Department of Commerce

5285 Port Royal Road

Springfield, Virginia 22151

Price: Printed Copy $\$ 5.45 ;$ Microfiche $\$ 2.25$ 
Environmental and Earth Sciences (UC-11)

ARGONNE NATIONAL LABORATORY

9700 South Cass Avenue

Argonne, Illinois 60439

\section{REDUCTION OF ATMOSPHERIC POLIUTION \\ BY THE APPLICATION OF FLUIDIZED-BED COMBUSTION \\ AND REGENERATION OF \\ SULFUR-CONTAINING ADDITIVES}

Annual Report

July 1973-June 1974

by

G. J. Vogel, W. M. Swift, J. F. Lenc,

P. T. Cunningham, W. I. Wilson, A. F. Panek,

F. G. Teats, and A. A. Jonke

Chemical Engineering Division

Work performed under an agreement between the

U. S. Atomic Energy Commission and

U. S. ENVIRONMENTAL PROTECTION AGENCY

OFFICE OF AIR PROGRAMS

DIVISION OF CONTROL SYSTEMS

EPA-IAG-149 (D)

and the

OFFICE OF COAL RESEARCH

U. S. DEPARTMENT OF INTERIOR

14-32-0001-1543

\section{Preceding Annual Reports}

ANL/ES-CEN-1001

ANL/ES-CEN-1002

ANL/ES-CEN-1004

ANL / ES-CEN-1005

ANL/ES-CEN-1006

$$
\begin{array}{lll}
\text { July } & 1968 \text { - June } & 1969 \\
\text { July } & 1969 \text {-June } & 1970 \\
\text { July } & 1970 \text { - June } & 1971 \\
\text { July } & 1971 \text { - June } & 1972 \\
\text { July } & 1972 \text { - June } & 1973
\end{array}
$$




\section{THIS PAGE \\ WAS INTENTIONALLY \\ LEFT BLANK}


ABSTRACT . . . . . . . . . . . . . . . . . 10

SUMMARY. . . . . . . . . . . . . . . . . . . 11

INTRODUCTION . . . . . . . . . . . . . . . . . 22

BENCH-SCALE, PRESSURIZED, FLUIDIZED-BED COMBUSTION

EXPERIMENTS. . . . . . . . . . . . . . . . . . . 25

Raw Materials... . . . . . . . . . . . 25

Coals. . . . . . . . . . . . . . . . 25

Additive . . . . . . . . . . . . . . . 25

Inert Bed Material'.. . . . . . . . . . 25

Bench-Scale Equipment . . . . . . . . . . . . . 26

Experimental Procedure. . . . . . . . . . . . . . .29

Combustion Experiments with Arkwright Coal. . . . . . 29

Sulfur Dioxide Retention . . . . . . . . . 32

Analysis of Variance of $\mathrm{SO}_{2}$ Data. . . . . . 32

Regression Analysis of $\mathrm{SO}_{2}$ Data . . . . . . . 33

Kinetics of $\mathrm{SO}_{2}$ Retention . . . . . . . . 34

Nitrogen Oxide Emissions . . . . . . . . . . . 38

Combustion Efficiency. . . . . . . . . . . . . 39

Combustible Carbon Hold-up in the Fluidized Bed. . . 42

Additive Utilization . . . . . . . . . . . . . 42

Removal of Additive from Combustor by Elutriation. - 45

Terminal Velocities of Additive Particles . . 45

Experimental Elutriation Rates. . . . . . . 45

Decrepitation of Tymochtee Dolomite . . . . . 48

Heat-Transfer Coefficients at the Combustor Wall . • 49

Solids Loading in the Flue Gas . . . . . . . . . . 52

Carbon, Sulfur, and Calclum Material Balancco. .. . 56

Particle-Size Distribution of Fluidized-Bed and

Elutriated Solids. . . . . . . . . . . . 56

Combustion-Side Corrosion of Internal Cooling

Coils. . . . . . . . . . . . . . . 58

Combustion of Low-Sulfur Subbituminous and Lignite Coals. 61

Operating Performance. . . . . . . . . . . 61

Sulfur Dioxide Retention . . . . . . . . . . 61

Nitrogen Oxide Emissions ............. 64

Combustion Efficiencies. . . . . . . . . . . . 64

Calcium Utilization. . . . . . . . . . . . . 64

Material Balances and Screen Analyses. ....... 64 
Effect of Combustor Pressure and Temperature on the Concentration of NO and Other Gases in the Flue Gas... . . 65

Pressure Effect on NO Levels in the Flue Gas. . . . 66

Pressure Effect on the Concentration of Flue-Gas Components Other Than NO.. . . . : . . . . . . . . Effect of Temperature on the Concentration of FlueGas Constituents............... 67

TRACE-ELEMENT DISTRIBUTION STUDIES. . . . . . . . . 70

Solids Sampling. . . . . . . . . . . . . . 71

Hilnp-fas Sampling. . . . . . . . . . . . . . 71

Analytical Melliuds .................. 73

Results....................... 73

Mercury Mass Balances . . . . . . . . . . 75

Iodine Monochloride Scrubbing Solution . . . . 77

Condensation of Mercury on Flue-Gas Ductwork . . 77

Efficiency of Mercury Sampling Apparatus . . . 77.

Retention of Mercury in Solid Products of Combustion. 78

Lead and Beryllium Mass Balances. . . . ...... 78

Preferential Concentration of Lead and Beryllium in

the Finer Particulate Matter. . . . . . . . . . 81

Fluoride Mass Balances. . . . . . . . . . . . 84

Neutrún Act1vation Analysis, Developmental Work . . 84

Sodium Concentrations in Flue-Gas Particulates. . . . 86

Photomicrographs of Flue-Gac Particulates . . . . X

KINETICS OF THE REACTION OF HALF-CALCINED DOLOMITE WITH SULFIIR

DIOXIDE $\ldots \ldots$

Experimental . . . . . . . . . . . . . . 90

Apparatus . . . . . . . . . . . . . . . 90

Materials . . . . . . . . . . .... 90

Procedure.. . . . . . . . . . . . . . . . 91

Results and Discussion... . . . . . . . . . 92

ACKNOWLEDGMENTS . . . . . . . . . . . . . . . . 97

REFERENCES. . . . . . . . . . . . . . . . . . 98 
$\underline{\text { Page }}$

APPENDIX A. Characteristics of Raw Materials Used in Fluidized-

Bed Combustion Experiments. . . . . . . . . . 101

APPENDIX B. Carbon, Sulfur, and Calclum Material Balances for

Combustion Experiments. . . . . . . . . 107

APPENDIX C. Screen Analysis Data. . . . . . . . . . . 121

APPENDIX. D. Concentration of Fine Particulate Matter in the Flue Gas Exhausted from the Fluidized-Bed Combustion System. 126

APPENDIX E. Trace-Element Analytical Procedures . . . . . . . . 129

APPENDIX F. Conversion Factors, English to Metric Units. . . . . . 134 


\section{LIST OF FIGURES}

No. $\underline{\text { Title }}$

Page

1. Simplified Equipment Flowsheet of Bench-Scale FluidizedBed Combustor and Associated Equipment. . . . . . . .

2. Detail Drawing of 6-in.-Dia, Pressurized Fluidized-Bed Combustor . . . . . . . . . . . . . . .

3. Effect of Ca/S Mole Ratio on $\mathrm{SO}_{2}$ Level in Flue Gas. . - 35

4. Effect of Superficial Gas Velocity on $\mathrm{SO}_{2}$ Level in Flue Gas................. . . . 36

5. Effect of Bed Temperature on $\mathrm{SO}_{2}$ Level 1n Flue Gas. . . . 37

6. NO Concentration in Flue Gas as a Function of $\mathrm{Ca} / \mathrm{S}$ Mole Ratio . . . . . . . . . . . . ... . . 40

7. Combustion Efficiency as a Function of Bed Temperature. . 41

8. Additive Ut1lization of Final Bed Material as a Function of Ca/S Mole Ratio. . .. . . . . . . . . . . . . 44

9. Terminal Gas Velocity of Solid Particles in a Gas Flow as a Function of Particle Diameter for Various Physical Situations.

10. Entrainment of Sulfated Dolomite as a Function of Superficlal Gas Velocity. . . . . . . . . . . .

11. Various Size Fractions of Primary Cycine Product Recovered during Combustion Experiment VAR-6-2R . . . .

12. Factors Considered in the Calculation of Heat-Transfer Coefficients at the Combustor Wall. . . . . . . . . .

13. The Effect of Velocity on Calculated Bed-to-Wall HeatTransfer Coefficients . . . . . . . . . . . . . .

14. Solids Loading of Flue Gas Leaving the Combustor as a Function of $\mathrm{Ca} / \mathrm{S}$ Mole Ratio and Gas Velocity. ..... .

15. Mean Particle Diameters of Solid Samples from the "VAR" Series of Combustion Experiments vs. Fluidizing-Gas Velocity.

16. Samples Number 3 and 11 , Showing Intergranular-Type Corrosion on the Bed-Side Wall of an Internal Cooling Coil Immersed in the Fluidized Bed. . . . . . . . . . . 
No. $\quad \underline{\text { Title }}$ Page

17. Photomicrograph and Electron Microprobe Scanning Images of Intergranular-Type Corrosion Found in Process-Gas Side of Sample Removed from an Internal Cooling Coil in the Freeboard Area (All Images $40 \times 50 \mu \mathrm{m}$ ). . . . . 60

18. Effect of Pressure on Concentration of NO in Flue Gas. - 66

19. Effect of Pressure on Concentration of Flue-Gas Components Other Than NO for Series NOX-I. . . . . 68

20. Effect of Pressure on Concentration of Flue-Gas Components Other Than NO for Series NOX-II . . . . . .

21. Effect of Temperature on Concentration of Flue-Gas Components . . . . . . . . . . . . . . . . . . .

22. Experimental Flow System for Flue-Gas Sampling . . . .

23. Flue-Gas Sampling Apparatus for Measuring Concentrations of $\mathrm{Hg}, \mathrm{F}^{-}$, and Entrained Particulate Matter. ... . .

24. Particle Size Distributions for Fly Ash Recovered by the Primary and Secondary Cyclones in Experiment TRACE-3 . .

25. Photomicrographs of Arkwright Coal and F1y Ash Recovered in Particulate Removal and Sampling Devices During Combustion Experiment TRACE-3. . . . . . . . . . .

26. Schematic Diagram of the TGA Apparatus . . . . . . 91

27. Percent Conversion vs. Time for Various $\mathrm{SO}_{2}$

Concentrations in the Reactant Gas at $750^{\circ} \mathrm{C} . . . . .$.

28. Initial Reaction Rate of $\mathrm{SO}_{2}$ with 1337 Dolomite as a Function of $\mathrm{SO}_{2}$ Concentration in the Presence of $\mathrm{H}_{2} \mathrm{O}$. .

29. Initial Reaction Rate of $\mathrm{SO}_{2}$ with 1337 Dolomite as a Function of $\mathrm{SO}_{2}$. Concentration in the Absence of $\mathrm{H}_{2} \mathrm{O}$. . .

30. Arrhenius Plot for the Reaction of $\mathrm{SO}_{2}$ with Half-Calcined 1337 Dolomite. . . . . . . . . . . . . . . .

31. Percent sulfation vs. Time for a) $[\mathrm{CaO}+\mathrm{MgO}]$; b) $\left[\mathrm{CaCO}_{3}\right.$ $+\mathrm{MgO}]$; and c) $\mathrm{MgO}$ at $750^{\circ} \mathrm{C}$............ 


\section{LIST OF TABLES}

No.

1. Designed Operating Conditions and Matrix Representation for the Eleven Experiments in the Latin-Square Experimental Design....................

2. Operating Conditions and Flue-Gas Analyses for the Eleven Experiments Investigating the Effects of Independent Operating Variables . . . . . . . . .

3. Analysis of Variance of $\mathrm{SO}_{2}$ Flue-Gas Levels in the $3 \times 3$ Latin-Square Designed Series of "VAR". Experiments . . . . 32

4. Comparisü Belween Ixperimental and Calculated Values fur Lhe $\mathrm{SO}_{2}$ Flue-Gas Levels in the "VAR" Experiments. • 34

5. Analysis of Variance of NO Flue-Gas Levels in the $3 \times 3$ Latin-Square Designed Series of "VAR" Experiments . . . . 38

6. Combustion Efficiencies for "VAR"-Series Experiments. • 41

7. Combustible Carbon Content of Final Bed Material for "VAR"-Series Experiments. . . . . . . . . . . . 43

8. Calcium Utilization in Solids Outlet Streams for the Combustion of Arkwright Coal in a Fluldized Bed of Tymnchtee Dolomite. . . . . . . . . . . . . . 43

9. Inventory of +45 Mesh Additive Entering and Leaving the Combustion System for the Eleven Experiments in the "VAR". Series of Combustion Experiments. . . . . . . . . 50

10. Heat-Transfer Coefficients for the "VAR" Series of Statistically Designed Combustion Experiments. . . . . . 53

11. Distribution of Flue-Gas Particulațes in "VAR"-Series Experiments Expressed in Units of Grains/scf. . . . . . . 54

12. Distribution of Flue-Gas Particulates in "VAR"-Series Experiments Expressed in Units of $1 \mathrm{~h} / 10^{6}$ BTU. . .. . . . 55

1J. Carbon, Sulfur, and Calcium Material Balances for "VAR" Series of Experiments . . . . . . . . . . . . .

14. Actual Operating Conditions and Flue-Gas Analysis for Combustion Experiments with Low-Sulfur Subbituminous and Lignite Coals . . . . . . . . . . . . . . . 
15. Potential Effect of the Calcium Content of Coals Tested on the Retention of Sulfur during Fluidized-Bed

Combustion. . . . . . . . . . . . . . 63

16. Trace Elements of Interest and Their Order of Priority

for Experimental Investigation. . . . . . . . . . 70

17. Summary of Average Operating Conditions and Flue-Gas Compositions for Trace-Element Experiments. . . . . . . . 74

18. Mercury Materia1 Balances for Trace-Element Combustion Experiments . . . . . . . . . . . . . .

19. Lead Material Balances for Trace-Element Combustion Experiments . . . . . . . . . . . . . . . .

20. Beryllium Material Balances for Trace-Element Combustion Experiments .. ... . . . . . . . . . . . .

21. Concentrations of Trace, Minor, and Major Elements in Particulate Matter Recovered at Various Stages of Removal frum Flue Gás . . . . . . . . . . . . . . . . .

22. Ratio of Lead to Beryllium in the Raw Materials and in the Particulate Matter Removed from the Flue Gas during the "TRACE" Experiments . . . . . . . . . . . . .

23. Fluoride Material Balances for Trace-Element Combustion Experiments . . . . . . . . . . . . . . . . . :

24. Neutron Activation Results on Samples from the TRACE-3 Trace-Element Experiment. . . . . . . . . . . .

25. Sodium Material Balances for Trace-Element Combustion Experiments . . . . . . . . . . . . . . . . 


\section{REDUCTION OF ATMOSPHERIC POLLUTION BY THE APPLICATION. OF FLUIDIZED-BED COMBUSTION AND REGENERATION OF SULFUR CONTAINING ADDITIVES}

Annual Report

July 1973-June 1974

by

G. J. Vogel, W. M. Swift, J. F. Lenc, P. T. Cunningham, W. I. Wilson, A. F. Panek, F. G. Teats, and A. A. Jonke

\section{ABSTRACT}

The Argonne National Laboratory (ANL) program for developing and demnntrating the feacibility of fluidizedbed combustion for possible use in power and steam-plant applications is divided into three studies: (a) the combustion of coal in a pressurized combustor; (b) a determination of the distribution of trace elements in the combustion products; and (c) a fundamental investigation of the kinetics of additive sulfation and regeneration reactions.

A bench-scale, fluidized-bed combustion pilot plant capable of operating at 10-atm pressure* was used to evaluate the effects of operating variables on response variables such as $\mathrm{SO}_{2}$ and No levels in the flue gas, combustion efficiency, additive utilization, and heat-transfer coetticients. High retentions of sulfur $(>90 \%)$ and low No leve1s ( $<150 \mathrm{ppm})$ werc achieved. The iumbustor was alsn surcesstully tectcd using a variecy of coals: a highly caking, high-volatile bituminuus coal, a high ash subbltuminous coal, and a low-heating-value lignite.

Data, in the form of material balances, are reported for the four trace elements of primary concern: $\mathrm{Hg}, \mathrm{Pb}$, $\mathrm{Be}$, and $\mathrm{F}$. $\Lambda$ lsn reported ate data on $\mathrm{Na}$ concentrations in the particulate matter entrained in the flue gas from the cumbustor.

The kinetics of the reaction of half-calcined dolomite with $\mathrm{SO}_{2}$ were studled at atmospheric pressure by thermogravimetric analysis. The reaction was found to be first order with respect to the $\mathrm{SO}_{2}$ concentration in the presence of $\mathrm{H}_{2} \mathrm{O}$ vapor and approximately three-fourths order in the absence of $\mathrm{H}_{2} \mathrm{O}$ vapor.

* For convenience, a table of English to metric unit conversion factors is provided at the end of this report in Appendix F. 


\section{SUMMARY}

Argonne National Laboratory is investigating pollution control aspects of pressurized, fluidized-bed combustion in a program funded by the Control Systems Laboratory of the Environmental Protection Agency and by the office of Coal Research, Department of Interior. The program consists of investigating (1) the effects of operating variables at elevated pressures (up to $10 \mathrm{~atm}$ ) on $\mathrm{SO}_{2}$ removal, NO suppression in the flue gas, combustion efficiency, additive utilization, solids entrainment, and heat-transfer coefficients, (2) the ability of the system to process a variety of coals including bituminous, subbituminous, and lignite coals, (3) the quantity and type of trace-element contaminants in the flue gas, and (4) the kinetics of the reaction between $\mathrm{SO}_{2}$ and sulfur-accepting additives.

In the combustion studies, coal is completely combusted in a fluidized bed of dolomite using an excess of oxygen. Sulfur contained in the coal is released during combustion as $\mathrm{SO}_{2}$, which in the excess-oxygen environment reacts with the $\mathrm{CaO}$ in the dolomite to form $\mathrm{CaSO}_{4}$.

The reaction kinetics between $\mathrm{SO}_{2}$ and dolomite were studied at atmospheric pressure using a thermal gravimetric analyzer (TGA) unit.

\section{Bench-Scale, Pressurized, Fluidized-Bed Combustion Experiments}

Materials. Combustion experiments were made using a variety of coals of differing rank. The principal coal tested was a highly caking, high-volatile bituminous, Pittsburg seam coal from the Consolidation Coal Company's Arkwright Mine. Also tested, although less extensively, were a subbituminous coal from the Western Coal Company's San Juan Mine in New Mexico and a lignite from the Consolidation Coal Company's Glenharold Mine in North Dakota. The coals were fed to the combustor as received.

Tymochtee dolomite obtained from C. E. Duff and Sons, Huntsville, Ohio, was used in the experiments reported here. The additive was air-dried and screened to $=14+100$ mesh.

Equipment. The ANL bench-scale equipment, designed for operation to 10 atm pressure, consists of a fluidized-bed combustor, a compressor for supplying fluidizing-combustion air, a preheater for the fluidizing-combustion air, coal and additive feeders, and an off-gas system (cyclones, filters, gas-sampling equipment, and pressure letdown valve). The system is thoroughly instrumented and equipped with an automatic data logging system.

The combustion unit consists of a 6-in.-dia pipe, $11 \mathrm{ft}$ long. The exterior of the pipe is wrapped with electrical heaters (to heat the bed from room temperature to the coal-ignition temperature at the start of an experiment) and cooling coils (to cool the bed during coal 
combustion). Additional cooling is provided by halrpin coils immersed in the fluidized bed. Coal and additive are conveyed pneumatically and continuously to the fluidized bed from weighed hoppers. Each hopper has a rotary valve at the bottom for metering the coal or additive to the air-conveying stream. A constant bed level is maintained in the combustor by, use of an internal overflow pipe.

Combustion Experiments with Arkwright Coal. A serles of statistically designed experiments were made to measure the effects of the independent operating variables, temperature, fluidizing-gas velocity, and $\mathrm{Ca} / \mathrm{S}$ mole ratio (ratio of calcium content of dolomite feed to sulfur content of coal feed), on response variables such as $\mathrm{SO}_{2}$ and $\mathrm{NO}$ suppression in the flue gas, additive utilization, additive entrainment and decrepitation, combustion efficiency, and heat-transfer coefficients. The three levels of the variables tested were (1) temperature at 1450 , 1550 , and $1650^{\circ} \mathrm{F}$; (2) $\mathrm{Ca} / \mathrm{S}$ mole ratlo at 1,2 , and 3 ; and (3) gas veloc1ty at $2.0,3.5$ and $5.0 \mathrm{ft} / \mathrm{sec}$. All of the experiments were made at a pressure of $8 \mathrm{~atm}$ absolute, a 3-ft fluidized-bed height, and $3 \%$ oxygen in the flue gas.

Sulfur Dioxide Retention. Sulfur dioxide levels in the flue gas ranged from $850 \mathrm{ppm}$ at a $\mathrm{Ca} / \mathrm{S}$ mole ratio of 1.0 , gas velocity of $4.9 \mathrm{ft} / \mathrm{sec}$, and bed temperature of $1665^{\circ} \mathrm{F}$ to a low of $120 \mathrm{ppm}$ at a $\mathrm{Ca} / \mathrm{S}$ mole ratio of 2.9 , gas velocity of $2.1 \mathrm{ft} / \mathrm{sec}$, and bed temperature of $1445^{\circ} \mathrm{F}$ ( $\mathrm{SO}_{2}$ level at zero removal is $\sim 2300 \mathrm{ppm}$ ). These $\mathrm{SO}_{2}$ levels correspond, respectively, to emission rates of 1.5 .7 and $0.23 \mathrm{Ib} \mathrm{SO}_{2} / 10^{6} \mathrm{BTU}$ as compared with the EPA emission standard of $1.2 \mathrm{lb} \mathrm{\textrm {SO } _ { 2 }} / 10^{6} \mathrm{BTU}$.

For $\mathrm{Ca} / \mathrm{S}$ ratios above 2.0 , the $\mathrm{SO}_{2}$ removal 1 s generally greater than $90 \%$. The level of $\mathrm{SO}_{2}$ in the flue gas increases rapidly, however, with decreasing $\mathrm{Ca} / \mathrm{S}$ ratio and with increasing gas velnsity at low $\mathrm{Ca} / \mathrm{S}$ ratios. The combustion or bed temperature appears to have very little effect over the range of conditions tested. The observed variable effects on the $\mathrm{SO}_{2}$ retention strongly support the theory that the rate of $\mathrm{SO}_{2}$ uptake by the sorbent is diffusion limited.

The results indicate that for this coal and additive, and at a gas velocity of less than $5 \mathrm{ft} / \mathrm{sec}$ and a bed temperature of less than $1650^{\circ} \mathrm{F}$, it should be possible to operate close to a $\mathrm{Ca} / \mathrm{s}$ mole ratio of 1.0 , and still meet the EPA emission standard of $1.21 \mathrm{~b}$ of $\mathrm{SO}_{2} / 10^{6}$ BTU.

Nitrogen Uxide Emissions. Nitrogen oxide levels in the flue gas were extremely low over the range of operating conditions tested. Values varied from $270 \mathrm{ppm}$ at a $\mathrm{Ca} / \mathrm{s}$ mole ratio of 3.2 , temperature of $1630^{\circ} \mathrm{F}$, and gas velocity of $3.6 \mathrm{ft} / \mathrm{sec}$ to $120 \mathrm{ppm}$ at a Ca/s mole ratio of 1.0 , temperature of $1.665^{\circ} \mathrm{F}$, and velocity of $4.9 \mathrm{ft} / \mathrm{sec}$. These NO concentrations correspond, respectively, to emissions of 0.40 and $0.15 \mathrm{lb} \mathrm{NO} \mathrm{N}_{2} / 10^{6} \mathrm{BTU}$, as compared with the EPA emission standard of $0.701 \mathrm{~b} \mathrm{NO} \mathrm{NO}_{2} / 10^{6} \mathrm{BTU}$. 
The only variable that appeared to have a significant effect on the NO levels was the $\mathrm{Ca} / \mathrm{S}$ mole ratio, with the NO level increasing with increasing $\mathrm{Ca} / \mathrm{S}$ mole ratio.

Combustion Efficiency. Combustion efficiency varied directly with the combustion temperature, ranging from $289 \%$ at $1450^{\circ} \mathrm{F}$ to $297 \%$ at $1650^{\circ} \mathrm{F}$. These efficiencies are comparable to previously reported efficiencies obtained in atmospheric combustion experiments.

Combustible Carbon Hold-Up in the Fluidized Bed. To provide a measure of the combustible carbon hold-up in the fluidized bed during combustion, samples of the final bed material from each experiment were analyzed for total carbon and carbon present as carbonate ion. The combustible carbon content was taken as the difference between these two values. For the eleven experiments, the combustible carbon in the samples ranged from $<0.01$ to $1.60 \%$ and was $51.0 \%$ in seven of the experiments. These levels of carbon are sufficiently low to ensure safe, stable operating performance.

Additive Utilization. Utilization of additive in the final bed samples was found to vary inversely with $\mathrm{Ca} / \mathrm{S}$ ratio and was relatively unaffected by fluidizing-gas velocity or bed temperature. Utilization ranged from $280 \%$ at a Ca/s ratio of 1 to $\sim 35 \%$ at a $\mathrm{Ca} / \mathrm{S}$ ratio of 3 .

Additive utilization was consistently higher for the final bed material than for the elutriated solids collected in the primary cyclone. In addition, calcium utilization for elutriated solids generally increased the farther downstream the particulate matter in the flue gas was collected. The latter result is attributed to increasing reactivity with decreasing particle size.

Additive Entrainment. Entrainment of additive from the combustor was found to vary directly with the superficial gas velocity. Entrainment increased from a low of $5 \%$ (of the additive being fed to the combustor) at $2 \mathrm{ft} / \mathrm{sec}$ to as high as $80 \%$ at $5 \mathrm{ft} / \mathrm{sec}$.

Theoretical consideration was given to the terminal velocities associated with different sizes of dolomite particles. For a sphericity factor of $0.6,5 \mathrm{ft} / \mathrm{sec}$ corresponds to the terminal velocity of $\sim 16$ mesh additive particles. Since $80-90 \%$ of the dolomite feed had a terminal velocity below $5 \mathrm{ft} / \mathrm{sec}$, it is understandable that $80 \%$ of the additive fed was elutriated from the combustion at a gas velocity of $5 \mathrm{ft} / \mathrm{sec}$. It should be emphasized, however, that in a commercial unit, the problem of additive elutriation would be reduced considerably by selection of a suitable sorbent particle size.

A semi-quantitative attempt was also made to determine the contribution of additive decrepitation followed by elutriation of the resulting fines to the high entrainment rates. The method chosen to provide a measure of additive decrepitation was to inventory the +45 mesh additive entering and leaving the combustor. 
Average recoveries determined by the above procedure for each level of the three independent operating variables ranged from 92 to $103 \%$. The average recovery for all the experiments was $96 \%$. The results suggest that very little decrepitation of the dolomite occurred over the range of conditions tested.

Heat-Transfer Coefficients at the Combustor Wall. Values of heattransfer coefficients at the combustor wall were calculated for the eleven experiments in the study and were found to vary directly with the gas velocity. The values ranged from $\sim 40 \mathrm{BTU} /(\mathrm{hr})\left(\mathrm{ft}^{2}\right)\left({ }^{\circ} \mathrm{F}\right)$ at a gas velocity of $2 \mathrm{ft} / \mathrm{sec}$ to $\sim 115 \mathrm{BTU} /(\mathrm{hr})\left(\mathrm{ft}^{2}\right)\left({ }^{\circ} \mathrm{F}\right)$ at $5 \mathrm{ft} / \mathrm{sec}$.

Solids Loading in the Flue Gas. Solids loading in the flue gas leaving the combustor (before any particulate removal) varied directly with both the fluidizing-gas velocity and the $\mathrm{Ca} / \mathrm{S}$ mole ratio. Loadings ranged from 4.1 grains $/ \mathrm{ft}^{3}\left(7.3 \mathrm{lb} / 10^{6} \mathrm{BTU}\right)$ at a $\mathrm{Ca} / \mathrm{s}$ mole ratio of 1 and velocIty of $2 \mathrm{ft} / \mathrm{sec}$ to $23 \mathrm{grains} / \mathrm{ft}^{3}\left(39.1 \mathrm{lb} / 10^{6} \mathrm{BTU}\right)$ at a $\mathrm{Ca} / \mathrm{s}$ mole ratio of 3 and velocity of $5 \mathrm{ft} / \mathrm{sec}$. At gas velocities of $2,3.5$, and $5 \mathrm{ft} / \mathrm{sec}$, increasing the $\mathrm{Ca} / \mathrm{S}$ mole ratio from 1 to 3 increased the solids loading by 60,80 , and $125 \%$, respectively. While these results suggest the desirability of maintaining low $\mathrm{Ca} / \mathrm{S}$ ratios to minimize solids loading from the additive, high $\mathrm{Ca} / \mathrm{S}$ ratios could still be used at suitably selected gas velocities and sorbent particle sizes. Thus, the loadings quoted here are not representative of what could be achieved.

Combustion-Side Corrosion of Internal Cooling Coils. Corrosion on the external (bed) side of an internal cooling coil was studied af ter it had seen an estimated $500 \mathrm{hr}$ of operating time. Samples taken from the cooling coil where it extended below the surface of the bed exhibited intergranular corrosion to a depth of $\sim 30 \mu \mathrm{m}$, sensitization, and sigmaphase formation. A sample taken in the freeboard area of the combustor, $241 / 2 \mathrm{ft}$ above the bed, from a cooling coil which had seen $\sim 1000 \mathrm{hr}$ of

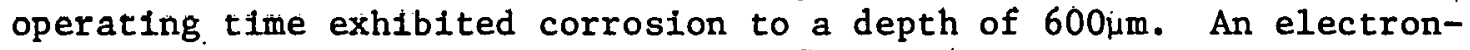
microprobe examination of the sample detected $\mathrm{Fe}$ and $\mathrm{Ni}$ depletion and the presence of sulfur along the grain boundaries to the depth of corrosion.

Combustion of Low-Sulfur Subbituminous and Lignite Coals. Experiments were made in the 6-in.-dia pressurized combustor to determine whether any difficulties would be encountered in processing a San Juan mine subbituminous coal with a high ash content of $17 \%$ and a Glenharold mine lignite with a low heating value of $7,625 \mathrm{BTU} / 1 \mathrm{~b}$. The nominal operating conditions for the two experiments were a bed temperature of. $1550^{\circ} \mathrm{F}$, gas velocity of $3.5 \mathrm{ft} / \mathrm{sec}$, and $0_{2}$ concentration of $3 \%$ in the dry flue gas ( $\sim 15 \%$ excess air). Due to the low sulfur content ( $<1$ wt. \%) of the western coals, a $\mathrm{Ca} / \mathrm{S}$ mole ratio of 1 was used for the experiments.

Operating Performance. As with the high-volatile bituminous Arkwright coal, the operating performance of the fluidized-bed combustor in processing the western coals was excellent, thus demonstrating the versatility of the fluidized-bed concept for processing coals of widely varying rank and quality. 
Sulfur Dioxide Retention. The $\mathrm{SO}_{2}$ levels of 250 and $120 \mathrm{ppm}$ observed for the combustion of the subbituminous and lignite coals, respectively, correspond to emissions of 0.45 and $0.21 \mathrm{lb} \mathrm{SO}_{2} / 10^{6}$ BTU. The combustion of Arkwright coal under similar operating conditions would have a projected $\mathrm{SO}_{2}$ emission of $610 \mathrm{ppm}$ or $1.2 \mathrm{lb}$ $\mathrm{SO}_{2} / 10^{6}$ BTU. The above emissions represent $\mathrm{SO}_{2}$ retentions of approximately 72,72 and $85 \%$ for the bituminous, subbituminous, and lignite coals, respectively.

The somewhat higher retention reported for the combustion experiment with lignite suggests that the calcium in the coal may be an active agent in helping to retain $\mathrm{SO}_{2}$ during combustion.

Nitrogen Oxide Emissions. The No levels of $150 \mathrm{ppm}$ and 130 ppm, respectively, for the combustion experiments with the subbituminous and lignite coals correspond to emissions of 0.19 and 0.18 Ib $\mathrm{NO}_{2} / 10^{6}$ BTU. The projected emission for the Arkwright coal (140 ppm) under similar conditions is also $0.191 \mathrm{~b} \mathrm{NO}_{2} / 10^{6} \mathrm{BTU}$.

Combustion Efficiencies. Combustion efficiencies for the two experiments were 94 and $97 \%$ for the San Juan and Glenharold coals, respectively. These values agree quite well with the combustion efficiency of $94 \%$ reported for the Arkwright coal at a combustion temperature of $1550^{\circ} \mathrm{F}$.

Dolomite Utizization. Calcium utilizations for the final-bed material of 74 and $71 \%$ for the combustion experiments with the San Juan and Glenharold coals, respectively, in Tymochtee dolomite at a $\mathrm{Ca} / \mathrm{S}$ mole ratio of 1.0 , are in relatively good agreement with the 76 to $83 \%$ utilizations reported above for combustion experiments with Arkwright coal using the same dolomite and the same mole ratio.

Effect of Combustor Pressure and Temperature on the Concentration of NO and Other Gases in the Flue Gas. Two series of experiments were conducted to specifically study the effect of combustor operating pressure on concentrations of NO and other gases in the flue gas. The NOX-I series involved the combustion of Arkwright coal in a fluidized bed of Alundum. In the NOX-II series, Arkwright coal was combusted in a fluidized bed of sulfated dolomite while feeding dolomite at a $\mathrm{Ca} / \mathrm{S}$ feed mole ratio of 1.5 . Nominal operating conditions in both series were a fluidized-bed temperature of $1550^{\circ} \mathrm{F}, 3 \% \mathrm{O}_{2}$ in the flue gas, and a fluidizing-gas velocity of $3.5 \mathrm{ft} / \mathrm{sec}$. Each of the two series of experiments consisted of six parts, with the combustor pressure ranging from 1 to $8 \mathrm{~atm}$. In a third series of experiments, the system pressure was maintained at $4 \mathrm{~atm}$, and the bed temperature was maintained at 1450,1550 , and $1650^{\circ} \mathrm{F}$.

In addition to the concentrations of gases ordinarily monitored in the flue gas $\left(\mathrm{O}_{2}, \mathrm{CO}_{2}, \mathrm{SO}_{2}, \mathrm{CO}\right.$, $\mathrm{NO}$, and $\left.\mathrm{CH}_{4}\right)$, instrumentation was installed for the continuous or intermittent determination of 
ammonia, hydrogen, and $\mathrm{C}_{2}-\mathrm{C}_{4}$ hydrocarbons.

Pressure Effect on NO Levels in the Flue Gas. In the absence of dolomite, the NO level in the flue gas increased from less than $200 \mathrm{ppm}$ at $8 \mathrm{~atm}$ to $21600 \mathrm{ppm}$ at $1 \mathrm{~atm}$. An NO level of $1600 \mathrm{ppm}$ is unusually high and may not be representative.

In the presence of dolomite (NOX-II series), an increase in NO is also observed at reduced pressures, although it is considerably less pronounced than in the first series of experiments. The level of NO increased from $\sim 200 \mathrm{ppm}$ at 8 atm to around $400 \mathrm{ppm}$ at $1 \mathrm{~atm}$.

Pressure Effect on Concentration of Flue-Gas Components Other Than NO, Analysis of the data from the NOX experiments can be summarized as follows:

1. The $\mathrm{SO}_{2}$. concentration is relatively unaffected by changes in system pressure.

2. Methane levels in the flue gas tend to increase moderately as the pressure is reduced from 8 to 6 atm and then increase rapidly (up to $400 \mathrm{ppm}$ ) as the pressure i.s reduced to $1 \mathrm{~atm}$.

3. In the presence of dolomite, Co levels increased from $170 \mathrm{ppm}$ at $8 \mathrm{~atm}$ to over $2000 \mathrm{ppm}$ at $1 \mathrm{~atm}$. In the absence of dolomite, the co level passed through a minimum ( $100 \mathrm{ppm})$ at about 4 atm pressure and increased rapidly with either increasing or decreasing pressure. This phenomenon remains unexplained. in pressure.

4. The level of $\mathrm{H}_{2}(35 \mathrm{ppm})$ is relatively unaffected by changes

5. The levels of the other gases $\left(\mathrm{NH}_{3}, \mathrm{C}_{2} \mathrm{H}_{4}, \mathrm{C}_{2} \mathrm{H}_{6}, \mathrm{C}_{2} \overline{\mathrm{H}}_{4}, \mathrm{C}_{3} \mathrm{H}_{8}\right)$ were below the detection limits of the analytical instrumentation.

Effect of Temperature on Flue-Gas Constituents. Under the conditions at which the experiments were performed, temperature variations from $1450^{\circ} \mathrm{F}$ to $1650^{\circ} \mathrm{F}$ have little or no effect on the composition of the various flue-gas components tested.

Trace-Element Distribution Studies

The emisstons of biologically toxic trace elements such as $\mathrm{Hg}$ and Be from coal-burning power plants are receiving increasing attention as potentially dangerous air pollutants. Relative to conventional boilers, the lower combustion temperature of the fluidized-bed boiler and the presence of additive for $\mathrm{SO}_{2}$ retention may serve to reduce the emissions of trace pollutants.

The elements of primary. concern in the investigation are $\mathrm{Hg}$, $\mathrm{Pb}, \mathrm{Be}$, and $\mathrm{F}$. The approach being taken is to make mass balances 
around the combustor for as many of the trace elements as possible within the economic limitations of the study. This involves sampling and analyzing all the solid materials charged to or recovered from the combustor, including particulate matter entrained in the flue gas from the unit. Analysis of the flue gas is also made for the more volatile traceelement species, $\mathrm{Hg}$ and $\mathrm{F}^{-}$.

Four combustion experiments were made for the specific purpose of investigating the behavior of trace elements during combustion. Experiments TRACE-3 and TRACE-4B were made at a. bed temperature of $1550^{\circ} \mathrm{F}$, a pressure of $10 \mathrm{~atm}$, and $4 \% \mathrm{O}_{2}$ in the off-gas. Experiments TRACE-5A and TRACE-6 were made at $1650^{\circ} \mathrm{F}, .8 \mathrm{~atm}$, and $3 \% .0_{2}$ in the flue gas. In each set of experiments, the first experiment involved the combustion of Arkwright coal in a fluldized bed of alumina, whereas the second experiment involved the combustion of Arkwright coal in a fluidized bed of Tymoehtec dolomito.

Mercury Balances. Mercury balances for experiments TRACE-3 and TRACE-4B Indicated $\mathrm{Hg}$ recoveries, expressed as the percentage of $\mathrm{Hg}$ entering the combustor which can be accounted for in the combustion products, of 56 and 43\%, respectively. For experiments TRACE-5A and TRACE-6, the respective recoveries were only 29 and $25 \%$. The lower recoveries for the latter two experiments resulted from the decreased recovery of volatilized $\mathrm{Hg}$ in the flue gas which was down by a factor of 6 ( 3 and $5 \%$ vs. 19 and $34 \%$ ) from the prior experiments.

Analysis of the solid materials from the combustion indicate that essentially no $\mathrm{Hg}$ was retained by the fluidized bed and that from 10 to $35 \%$ of the mercury which entered the combustion was retained by the fly ash and elutriated additive removed from the flue gas. Data for conventional coal-fired boilers indicate a $\mathrm{Hg}$ retention of $\sim 10 \%$ by the recovered ash products.

Attempts are being made to indentify the cause for the poor recov-. ery of $\mathrm{Hg}$ in the combustion products. Particular question areas that are being examined include the following:

(1) The inability to detect mercury in the ICI scrubbing solutions used in sampling the flue gas.

(2) The recovery efficiency of the mercury sampling equip-. ment.

(3) The possibility that mercury is plating out or condensing on the walls of the flue-gas ductwork before reaching the sampling zone.

Lead and Beryllium Mass Balances. Lead balances for the four trace-element experiments range from 78 to $125 \%$ recovery of the lead entering the combustor. Beryllium balances were somewhat lower, ranging from 56 to $87 \%$. 
The results indicate that lead is essentially retained by the particulate matter in the combustion products. Emissions of $\mathrm{Pb}$, therefore, will be controlled by the efficiency of particulate removal from the flue gas. However, because the concentration of $\mathrm{Pb}$ in particulate matter increases with decreasing particle size, it appears obvious that the efficiency of lead removal will be somewhat lower than the efficiency of particulate removal.

The beryllium mass balances, with the lower recoveries, suggest the possible volatilization of beryllium (or compounds of beryllium) during combustion.

Aside from material balance considerations, the results seem to indicate that both $\mathrm{Pb}$ and $\mathrm{Be}$ concentrate preferentially in the finer particulate matter leaving the combustor. The preferential concentration of relatively nonvolatile trace elements in particles of smaller diameter has been reported by others for samples taken from ambient air and from the flue gas of çoal-fired puwer plants. Tt is suggested that the lower trace-element concentrations in the larger particles are simply the result of dilution by unburned carbonaceous materia1s.

Fluoride Mass Balances. The indicated recovery of flunride for the experiments at $1550^{\circ} \mathrm{F}$ are 123 and $110 \%$, which are reasonably acceptable values. The recoveries of 208 and $276 \%$ reported for the experiments at $1650^{\circ} \mathrm{F}$, however, are unaccountably high. The only differences in sampling between the two sets of experiments were the use of considerably larger flue gas samples and $\mathrm{Na}_{2} \mathrm{CO}_{3}$ scruhbers Instead of $\mathrm{NaHCO}_{3}$ scrubbers for the experiments at $1650^{\circ} \mathrm{F}$.

Perhaps the most significant observation that ran be made from the $F^{-}$balances is that a significantly higher retention of the $F^{-}$ appears to occur in the solid products of combustion when additive is present. The recoveries of $\mathrm{F}^{-}$in the solid samples were relatively consistent, being 56 and $62 \%$ for combustion with additive and only 23 and $5 \%$ for combustion in an alumina bed. A possible explanation for such a phenomenon could be the formation of CaF, which is a relatively stable compound.

Neutron Activation Analysis, Developmental Work: The analytical method of neutron activation analysis is being considered as a possible instrumental method for expanding the trace-element study to includc elements of second- and third-priority interest (Cd, As, $\mathrm{N} 1,7 . \mathrm{n}, \mathrm{Cu}, \mathrm{Ba}$, $\mathrm{Sn}, \mathrm{P}, \mathrm{Li}, \mathrm{Mn}, \mathrm{Cr}, \mathrm{Se}$, and V). A preliminary testing of the method was made by irradiating samples from the TRACE-3 experiment in the ANL CP-5 test reactor. After the irradiation, periodic $\gamma$-ray counts were taken using a $\mathrm{Ge}(\mathrm{L} i)$ detector for the purpose of identifying activation products and their relative activity levels, Concentration data for seven additional minor and trace elements are reported on the basis of the preliminary results. 
Encouraged by the preliminary results, the remaining samples from the trace-element combustion experiments are being analyzed (including a reanalysis of the TRACE-3 samples) by this technique. Additional developmental work (see Appendix D) is also being done to increase both the number of elements detected and the accuracy.

Sodium Concentrations in Flue-Gas Particulates. Samples from three of the TRACE experiments have been analyzed for $\mathrm{Na}$ because of the considerable interest that has been expressed in $\mathrm{Na}$ as a source of corrosion in a combined-cycle power system, particularly to the blades of a high-temperature gas turbine. The results indicate that $\mathrm{Na}$ is retained by the particulate matter during combustion, and that the concentration of $\mathrm{Na}$ in the particulate matter increases with decreasing particle size. Concentrations generally varied from 0.5 wt \% for material removed in the primary cyclone to $1.5-2.0$ wt \% for material removed in the primary and secondary filters.

Photomicrographs of Flue-Gas Particulates. Solid samples of Arkwright coal and fly ash recovered from the cyclones and Brink impactor at the conclusion of experiment TRACE-3, were examined under a scanning electron microscope. Photomicrographs obtained for several of the samples are presented. Unlike the generally spherically shaped fly ash emitted from conventional coal-fired combustors, the photomicrographs depict the fly ash from the fluidized-bed combustor as a rather fragile and flake-like material.

Kinetics of the Reaction of Half-Calcined Dolomite with Sulfur Dioxide

The work reported here represents the initial results obtained by a small basic-chemistry support program associated with the development of fluidized-bed combustion.

The active material used in this program is half-calcined dolomite which reacts with $\mathrm{SO}_{2}$ as indicated in equation (s-1)

$$
\left\lfloor\mathrm{CaCO}_{3}+\mathrm{MgO}\right\rfloor+\mathrm{SO}_{2}+0.5 \mathrm{O}_{2} \rightarrow\left\lfloor\mathrm{CaSO}_{4}+\mathrm{MgO}\right\rfloor+\mathrm{CO}_{2}
$$

For economic and environmental reasons, it is desirable to regenerate the reactive material from the product by some scheme such as that indicated by equations $(s-2)$ and $(s-3)$.

$$
\begin{aligned}
& {\left[\mathrm{CaSO}_{4}+\mathrm{MgO}\right]+4 \mathrm{H}_{2} \rightarrow[\mathrm{CaS}+\mathrm{MgO}]+4 \mathrm{H}_{2} \mathrm{O}} \\
& {\left[\mathrm{CaSO}_{4}+\mathrm{MgO}\right]+4 \mathrm{CO} \rightarrow[\mathrm{CaS}+\mathrm{MgO}]+4 \mathrm{CO}_{2}} \\
& {[\mathrm{CaS}+\mathrm{MgO}]+\mathrm{H}_{2} \mathrm{O}+\mathrm{CO}_{2} \rightarrow\left[\mathrm{CaCO}_{3}+\mathrm{MgO}\right]+\mathrm{H}_{2} \mathrm{~S}}
\end{aligned}
$$

where the concentration of $\mathrm{H}_{2} \mathrm{~S}$ resulting from equation ( $\mathrm{S}-3$ ) is sufficlently high to allow sulfur recovery in a Claus plant. 
The goals of this program are i) to determine the detailed kinetics of equations $(S-1),(S-2)$, and $(S-3)$; ii) to elucidate plausible mechanisms for these reactions; and iii) to determine the conditions that optimize each of these reactions. Kinetic results obtained at atmospheric pressure for equation $(S-1)$ are presented here.

Experimental Apparatus and Procedure. The experimental apparatus consists of an Ainsworth thermal gravimetric analyzer (TGA) unit. An automatic recording balance provides for continuous monitoring of the sample weight with an accuracy of $0.1 \mathrm{mg}$. The sample is located in a platinum basket that is suspended from one arm of the balance and hangs in the heated region of a quartz reactor tube. The temperature of the reaction zone is controlled to about $+2^{\circ} \mathrm{C}$ over the range from ambient to $1000^{\circ} \mathrm{C}$. Reaction gases are premixed and introduced into the reactor from the bottom.

Commercial, reseaicli-grade cylinder gases were used to make up the reactant-gas stream. The stone used in these experiments is designated dolomite 1337 and is supplied by Charles Pfizer and Co., Gibsonburg, Ohio; the dolomite has an empirical formula $\mathrm{Ca}_{1.14} \mathrm{Mg}_{0.86}$ $\left(\mathrm{CO}_{3}\right)_{2}$.

In a typical experiment, $200^{\circ} \mathrm{mg}$ of the dolomite-1337 particles having diameters in a narrow range around $1.1 \mathrm{~mm}(-16,+18 \mathrm{U}$. S. Standard Screen) are placed in the apparatus under a flow of $\mathrm{N}_{2}$ and $\mathrm{CO}_{2}$ and heated to $800^{\circ} \mathrm{C}$ at a rate of about $25^{\circ} / \mathrm{min}$ to half-calcine the stone. Calcination is followed by observing the weight change of the sample. When half-calcination of the stone is complete (usually after about $45 \mathrm{~min}$ ), sample temperature is adjusted to that selected for the experiment, the sample is isolated under the $\mathrm{N}_{2}$ and $\mathrm{CO}_{2}$ atmosphere, and the reactant gas mixture adjusted to the appropriate composition and flowrate for the experiment while hypassing the reaction tube. At lime zero, the reactant gas is diverted through the reaction tube dild the welght change of the sample observed as a function of time. The reaction is followed until the rate of weight change is negligible.

Results. The reaction rate, and hence the extent of the reaction at a given time, is a function of $\mathrm{SO}_{2}$ concentration. A plot was made of the $10 \mathrm{~g}$ of the initial reaction rate (Initial rates were actually evaluated at $t=1 \mathrm{~min}$ because of scatter in the data near $t=0$ ) versus the $\log$ of $\mathrm{SO}_{2}$ concentration. The straight line thus obtained had a slope of 1.08 and indicates that the reaction is first order with respect to $\mathrm{SO}_{2}$ concentration in the reactant gas under the reaction conditions tested.

It was noticed in several experiments that the concentration of water vapor in the reactant gas appeared to influence the reaction rate. A result from a series of experiments in which the concentration of water in the reactant gas was varied while the concentration of other components was constant indicated, however, that the reaction 
was essentially zero order with respect to water concentration. Another series of experiments was made in which the reactant gas was dry and the concentration of $\mathrm{SO}_{2}$ was varied. Under these conditions, it was observed that the rate varied with the 0.77 power of $\mathrm{SO}_{2}$ concentration. Thus it would appear that the rate determining step is different depending on whether or not water is present in the reactant gas. With water present, the reaction is 0.22 order with respect to oxygen concentration in the reactant-gas stream.

The temperature dependence of the reaction rate in experiments with water present was examined over the range from 500 to $850^{\circ} \mathrm{C}$ (at higher temperatures, the concentration of $\mathrm{CO}_{2}$ necessary to prevent decomposition of $\mathrm{CaCO}_{3}$ could not be maintained with the present apparatus). The initial reaction rate increased significantly with temperature over this range. An Arrhenius plot of the data shows a linear dependence of rate on $1 / T$ and yields an apparent activation energy of $7.3 \mathrm{kcal} / \mathrm{mol}$. Such a value does not point conclusively to a mechanism in which some chemical reaction is rate controlling but is somewhat greater than one might expect if the reaction is diffusion controlled.

Experiments were also made to assess the extent to which Mgo undergoes sulfation. It was found that the extent of sulfation of $\mathrm{MgO}$ is not great and the reaction rate is much less than that for the half-calcined stone. 


\section{INTRODUCTION}

The combustion of fossil fuels in a fluidized bed of calcined limestone particles is a potentially efficient and economically attractive process for the generation of steam for electric power production and other uses. The process results in greatly reduced emissions of both sulfur oxide and nitrogen oxide pollutants. Development work, evaluations, and design studies are being carried out by various organizations under contract with the U. S. Environmental Protection Agency (EPA) and the Department of Interior's Office of Coal Research (OCR). The AEC's Argonne National Laboratory (ANL) is one of the principal participants in the development program under interagency agreements with EPA and OCR. Other participants in the program include the British National Coal Board, Combustion Power Utility Company, Pope, Evans, and Robbins, Inc., Exxon Research and Engineering Company, and Weotinghouse Electric.

The fluidized-bed principle has been used extensively in the petroleum and chemical-process industries. As applied to foosil-fue1 combustion, the fluidized bed consists of particles of partially sulfated lime or dolomite that are held in suspension by the combustion air which enters through a grid at the bottom of the combustor. Coal, or any fossil fuel, is injected and burns in the bed, which is at a temperature of $1600-1700^{\circ} \mathrm{F}$. The heat of combustion is partially removed by generation of steam in boiler tubes immersed in the bed. The steam can be used as process steam or to generate electrical power. The fiuidized-bed heat-transfer rate from the hot bed particles to the outside metal surfaces of boiler tubes in the bed is high. The sulfur dioxide released during the burning of the coal is reacted with lime and, in the presence of excess oxygen in the bed, forms calcium sulfate.

$$
\mathrm{CaCO}_{3}+\mathrm{SO}_{2}+1 / 2 \mathrm{O}_{2}+\mathrm{CaSO}_{4}+\mathrm{CO}_{2}
$$

Fresh, crushed limestone (or dolomite) is injectcd continuously inlu the bed and the sulfated lime is removed continuously to keep the level of the bed constant. The sulfated lime that is removed can either be regenerated to recover sulfur which is stored, and lime, which is reused in the combustor, or the sulfated lime can be discarded with the ash from lie combustor.

While various regeneration schemes have been proposed, two processes appear particularly promising. The first process is a one-step reductive decomposition of $\mathrm{CaSO}_{4}$ at $\sim 2000^{\circ} \mathrm{F}$

$$
\mathrm{CaSO}_{4}+\mathrm{CO} \rightarrow \mathrm{CaO}+\mathrm{SO}_{2}+\mathrm{CO}_{2}
$$

The second process is a two-step method involving the reduction of $\mathrm{CaSO}_{4}$ to $\mathrm{CaS}$ at $1600-1700^{\circ} \mathrm{F}$ followed by reaction of the $\mathrm{CaS}$ with $\mathrm{CO}_{2} / \mathrm{H}_{2} \mathrm{O}$ at $1000-1300^{\circ} \mathrm{F}$ to release $\mathrm{H}_{2} \mathrm{~S}$

$$
\begin{aligned}
& \mathrm{CaSO}_{4}+4 \mathrm{CO} \rightarrow \mathrm{CaS}+4 \mathrm{CO}_{2} \\
& \mathrm{CaS}+\mathrm{CO}_{2}+\mathrm{H}_{2} \mathrm{O} \rightarrow \mathrm{CaCO}_{3}+\mathrm{H}_{2} \mathrm{~S}
\end{aligned}
$$


Several variations of the fluidized-bed combustion concept are under investigation for power-plant applications. First is a unit in which coal is burned at atmospheric pressure. The combustion heat is transferred to steam tubes immersed in the bed and to heat-recovery units outside the bed. A second variation is a pressurized unit in which the coal is burned at elevated pressure $(e . g ., 135 \mathrm{psig})$ in a fluidized bed. Steam for operating a steam turbine is raised by steam tubes immersed in the fluidized bed. In addition, the flue gas is expanded through a gas turbine. Exit gas from the turbine is passed through heat-recovery units. This variation is intended to take advantage of the higher thermal efficiencies offered by a gas turbine-steam turbine combined cycle. A third version is a fluidizedbed combustor that is operated adiabatically at elevated pressure. The heat of combustion is removed from the bed by providing a large excess of air, $150 \%$. The flue gas is first expanded through a gas turbine and is then exhausted to an unfired heat-recovery boiler. No steam-raising tubes are present in the bed.

Argonne National Laboratory has been conducting a basic research and development program since 1968 to demonstrate the feasibility and potential of fluidized-bed combustion for reducing sulfur and nitric oxide emissions in accordance with environmental standards established by state and federal regulatory agencies. Previous annual reports in the series have presented comprehensive data on fluidized-bed combustion and regeneration at atmospheric pressure. More recently, an experimental program was initiated at ANL to develop advanced technology in pressurized fluidized-bed combustion. Objectives of the program are to optimize the combustion process with respect to sulfur dioxide retention in the fluidized bed of additive, nitrogen oxide suppression in the flue gas, and combustion efficiency; determine the behavior and operability of the system over a wide range of operating conditions and with a variety of coals including subbituminous and lignite; characterize the distribution and emission of polluting trace elements from fluidized-bed combustion systems and compare these emissions with commercial, pulverized-fuel power plants; and elucidate basic mechanisms of sulfation and regeneration reactions. The work reported here has consisted of the following experimental investigations:

1. A statistically designed series of combustion experiments was made to investigate the effects of the three independent operating variables of $\mathrm{Ca} / \mathrm{S}$ mole ratio (mole ratio of calcium in the additive to sulfur in the coal), combustion temperature, and superficial fluidizing-gas velocity on $\mathrm{SO}_{2}$ and $\mathrm{NO}$ levels in the flue gas, combustion efficiency, additive utilization, additive decrepitation and entrainment, and heat-transfer coefficients. Three levels of the independent variables were investigated: (1) $\mathrm{Ca} / \mathrm{S}$ mole ratios of 1,2 , and 3 ; (2) combustion temperatures of 1450,1550 , and $1650^{\circ} \mathrm{F}$; and (3) fluidizing-gas velocities of $2.0,3.5$, and $5.0 \mathrm{ft} / \mathrm{sec}$. All experiments were made in the ANL 6-in.-dia pressurized, fluidized-bed combustor using high-volatile, bituminous Arkwright coal and Tymochtee dolomite at a pressure of $8 \mathrm{~atm}$, a $3-\mathrm{ft}$ fluidized-bed height, and $\sim 15 \%$ excess combustion air ( $3 \% \mathrm{O}_{2}$ in the dry flue gas). 
2. Two experiments were conducted in the ANL 6-in.-dia combustor to evaluate the adaptability of pressurized, fluidized-bed combustion technology for the combustion of low-rank coals. A San Juan mine subbituminous coal containing $18 \%$ ash and a Glenharold mine lignite coal with a heating value of only $7,400 \mathrm{BTU} / \mathrm{lb}$ were combusted at a $\mathrm{Ca} / \mathrm{S}$ mole ratio of 1.0 , bed temperature of $1550^{\circ} \mathrm{F}$, fluidizing-gas velocity of $3.5 \mathrm{ft} / \mathrm{sec}$, combustor pressure of $8 \mathrm{~atm}$ abs, fluidized-bed height of $3 \mathrm{ft}$, and $\sim 15 \%$ excess combustion air $\left(3 \% \mathrm{O}_{2}\right.$ in the dry flue gas). The experiments were evaluated for $\mathrm{SO}_{2}$ and No levels in the flue gas, combustion efficiencies, and additive utilizations.

3. The effects of combustor pressure and temperature on the concentration of $\mathrm{SO}_{2}$, $\mathrm{NO}, \mathrm{CO}, \mathrm{CH}_{4}, \mathrm{NO}_{2}, \mathrm{NH}_{3}, \mathrm{H}_{2}$ and $\mathrm{C}_{2}-\mathrm{C}_{4}$ hydrocarbons were determined on the basis of three series of experiments in the 6-in.-dia combustor. The first series of experiments involved the combustion of Arkwright coal in a fluidized bed of inert solids (Alundum). In the second series, Arkwright coal was combusted in a fluidized bed of Tymochtee dolomite while fecding the dolomitc at a $\mathrm{Ca} / \mathrm{S}$ mole ratio of $1 . \overline{5}$. Operating conditions for both series were a combustion temperature of $1550^{\circ} \mathrm{F}$, a fluidizing-gas velocity of $3.5 \mathrm{ft} /$ sec and $3 \% \mathrm{O}_{2}$ in the flue gas. Each of the two series of experiments consisted of six parts with the combustor pressure ranging from 1 to 8 atm abs. In the third series of experiments, the system pressure was maintained at $\sim 4 \mathrm{~atm}$ abs and the bed temperature set at 1450, 1550, and $1650^{\circ} \mathrm{F}$.

4. Two sets of experiments were completed in the 6-in.-dia combustor to characterize the distribution and emission of trace elements from fluidized-bed combustion systems. Data were obtained for the biologically toxic trace elements, $\mathrm{Hg}, \mathrm{Pb}, \mathrm{F}$, and $\mathrm{Be}$, and for $\mathrm{Na}$. In each set of combustion experiments, Arkwright coal was first combusted in a fluidized bed of inert solids (Alundum) and then in a fluidized bed of Tymochtee dolomite under nominally similar operating conditions. The first set of experiments were made at a bed temperature of $1550^{\circ} \mathrm{F}$, combustor pressure of $10 \mathrm{~atm}$ abs, and $\sim 4 \% \mathrm{O}_{2}$ in the flue gas. The second set of experiments were made at $1650^{\circ} \mathrm{F}, 8$ atm abs, and $\sim 3 \% 0_{2}$ in the flue gas.

5. Reaction kinetics were also investigated using thermogravimetric analysis techniques. Results are presented on the effect of $\mathrm{SO}_{2}$ concentration on the rate of reaction between $\mathrm{SO}_{2}$ (in the absence and presence of $\mathrm{H}_{2} \mathrm{O}$ ) and half-calcined dolomite; on the effect of water vapor and oxygen on the sulfation rate of half-calcined dolomite; on the temperature dependence of the sulfation reaction with water vapor present; and on the reaction rate between $\mathrm{MgO}$ and reaction gases containing $\mathrm{SO}_{2}, \mathrm{O}_{2}$, and $\mathrm{H}_{2} \mathrm{O}$. 
BENCH-SCALE, PRESSURIZED, FLUIDIZED-BED COMBUSTION EXPERIMENTS

Experiments were performed in the ANL, 6-in.-dia, pressurized, fluidized-bed combustor to demonstrate the feasibility and potential of fluidized-bed combustion at elevated pressures (up to $10 \mathrm{~atm}$ ). Specific objectives of the experiments were to evaluate the effects of combustor operating variables on $\mathrm{SO}_{2}$ removal, NO suppression in the flue gas, combustion efficiency, additive utilization, solids entrainment, and heat-transfer coefficients. The results of these experiments are reported below. Also reported are the results of experiments made with low-rank coals and experiments made to measure the distribution and concentration levels of trace elements entering and leaving the combustion system.

$\underline{\text { Raw Materials }}$

Coals. Combustion experiments were made using a variety of coals of differing rank. The principal coal tested was a highly caking, high-volatile bituminous, Pittsburgh seam coal obtained from the Consolidation Coal Company's Arkwright mine. As received, the coal contained $2.82 \mathrm{wt} \% \mathrm{~S}$ and $7.68 \mathrm{wt} \%$ ash, had a heating value of $13,700 \mathrm{BTU} / 1 \mathrm{~b}$, and had an average particle size of $323 \mu \mathrm{m}$. Also tested, although less extensively, were a subbituminous coal obtained from the Western Coal Company's San Juan mine in New Mexico (provided by the Public Scrvice Company of New Mexico) and a lignite obtained from the Consolidation Coal Company's Glenharold mine in North Dakota. Respectively, the coals, as received, contained 0.78 and 0.53 wt $\% \mathrm{~S}$ and 17.0 and $6.11 \mathrm{wt} \%$ ash, had heating values of 9,620 and 7,620 $\mathrm{BTU} / 1 \mathrm{~b}$, and had average particle sizes of 340 and $353 \mu \mathrm{m}$. Complete data on the chemical and physical characteristics of the three coals are presented in Tables A-1 to A-3 in Appendix A. The coals were fed to the combustor as received.

Additive. A Tymochtee dolomite ( 250 wt $\% \mathrm{CaCO}_{3}$ and $\sim 30$ wt \% $\mathrm{MgCO}_{3}$ ) obtained from C. E. Duff and Sons, Huntsville, Ohio, was used in all of the experiments requiring a sulfur-accepting additive. Prior to its use in the combustor, the dolomite was a1r-dried dud duuble screened using 14- and 100-mesh screens. As fed to the combustor, the dolomite had an average particle size of $750 \mu \mathrm{m}$. Table A-4 in Appendix A summarizes the chemical characteristics and particle-size distribution of the Tymochtee dolomite.

Inert Bed Material. A high-purity Type 38 Alundum grain (electrically fused $\mathrm{Al}_{2} \mathrm{O}_{3}$ ) was obtained from the Norton Company for use in combustion experiments that required a fluidized-bed of chemically inert solids. The Alundum, which had a nomlnal grit size of 30 mesh, is typically analyzed at 99.5 wt $\% \mathrm{Al}_{2} \mathrm{O}_{3}$. A typical chemical analysis and particle-size distribution for the Alundum are given in Table A-5 of Appendix A. 
Bench-Scale Equipment

The experimental equipment and instrumentation consist of a 6-in.-dia, fluidized-bed combustor which can be operated at pressures up to $10 \mathrm{~atm}$, a compressor to provide fluidizing-combustion air, a preheater for the fluidizing-combustion air, peripheral-sealed rotary feeders for metering solids into an air stream entering the combustor, two cyclone separators and two filters in series for solids removal from the flue gas, associated heating and cooling arrangements and controls, and temperature and pressure sensing and display devices. A simplified schematic flowsheet of the combustion equipment is presented in Fig. 1.

Details nf the fluidized-bed combustor are illuslrated in F1g.'2. The reaction vessel consists of a 6-in.-dia, sched11. 40 pipe (Type $316 \mathrm{SS})$, approximately $11 \mathrm{ft}$ long. The reactor 1 s centrally contained inside a 9-ft section of 12-in.-dia schedule 10 pipe (Type 304 SS). A bellows expansion joint is incorporated into the outer shell to accommodate differential thermal expansion between the pipes. A bubble-type gas distributor is flanged to the bottom of the inner vessel. Fluidizing-air inlets, thermocouples for monitoring bed temperatures, solids feed lines, and solids removal lines are accommodated by the distributor. The coal and additive feed lines extend 2 in. above the top surface of the distributor plate and are angled $20^{\circ}$. from the vertical toward the longitudinal axis of the combustor. A constant bed height is maintained in the combustor by use of either a 36-in.- or 48-in.-high standpipe. The 6-in:-dia pipe is alternately wrapped with resistance-type heating elements and cooling coils onto which has been applied a layer of heat-conducting copper and then an overlay of oxidation-resistant stainless steel. Additional cooling capacity is provided by five internal, hairpin-shaped cooling coils which extend down from the flanged top of the combustor to within 12 in. of the top surface of the distributor. The coolant is water entrained in air.

Fluidizing-combustion air is supplied by a 75-hp, screw-type compressor capable of delivering $100 \mathrm{cfm}$ at $150 \mathrm{psig}$. The air can be heated to approximately $1000^{\circ} \mathrm{F}$ in a 6-in.-dia, 10-ft-tall preheater that has eight, 2700-watt, clam-she11-type heaters inside it to provide heat.

Coal and dolomite additive are pneumatically fed from hoppers to the combustor using two, 10-in.-dia rotary valve feeders. The feeders and hoppers are mounted on platform-type scales.

The flue gas is sampled continuously and is analyzed routinely for the components of primary importance. Continuous determinations of nitrogen oxide, sulfur dioxide, methane, and carbon monoxide are made using infrared analyzers. Oxygen is also monitored continuously using a paramagnetic analyzer. Intermittent carbon dioxide analyses of the flue gas are made by gas chromatography. Prior to and during each 


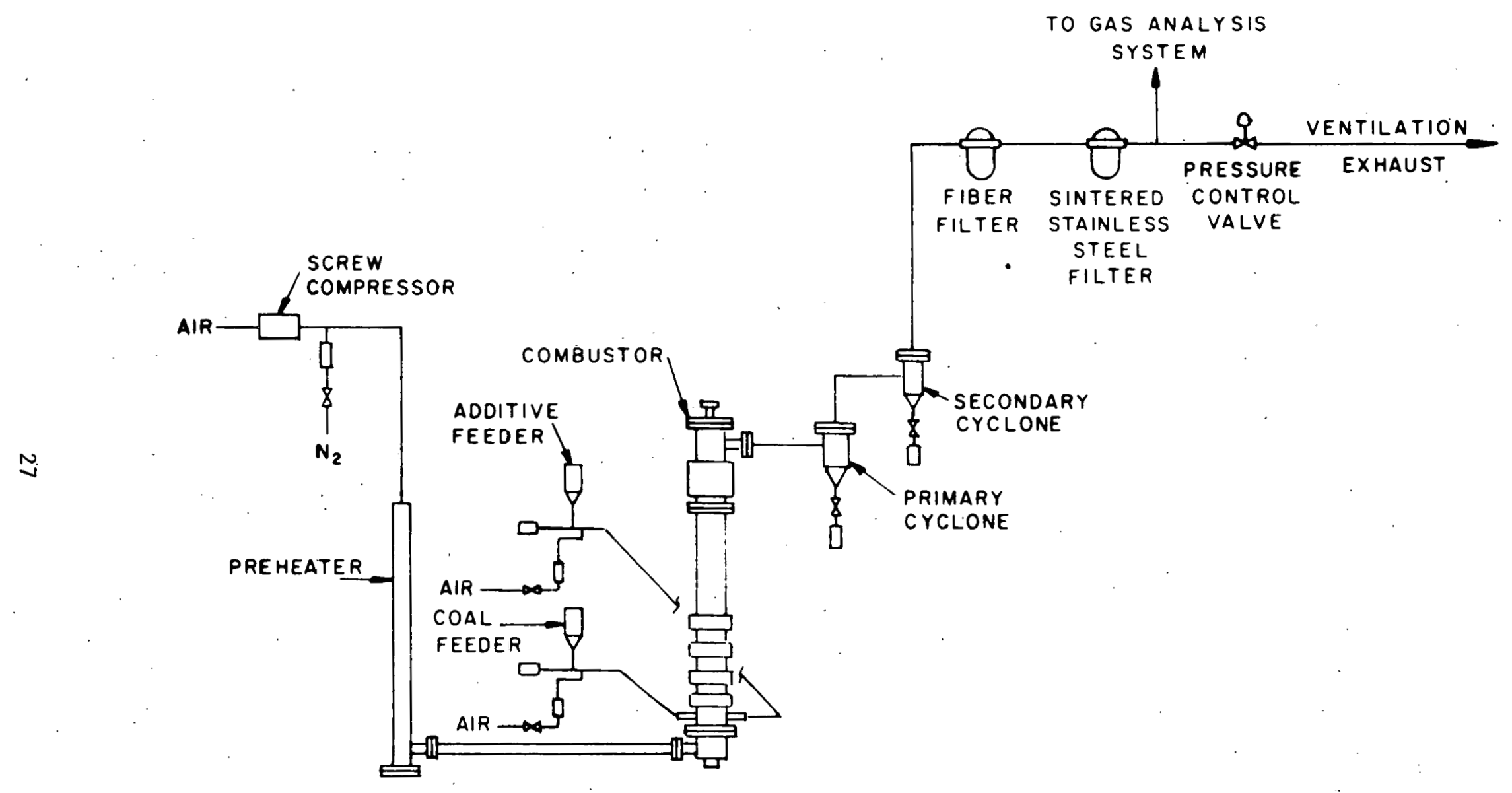

Figure 1. Simplified Equipment Flowsheet of Bench-Scale Fluidized-Bed Combustor and Associated Equipment 


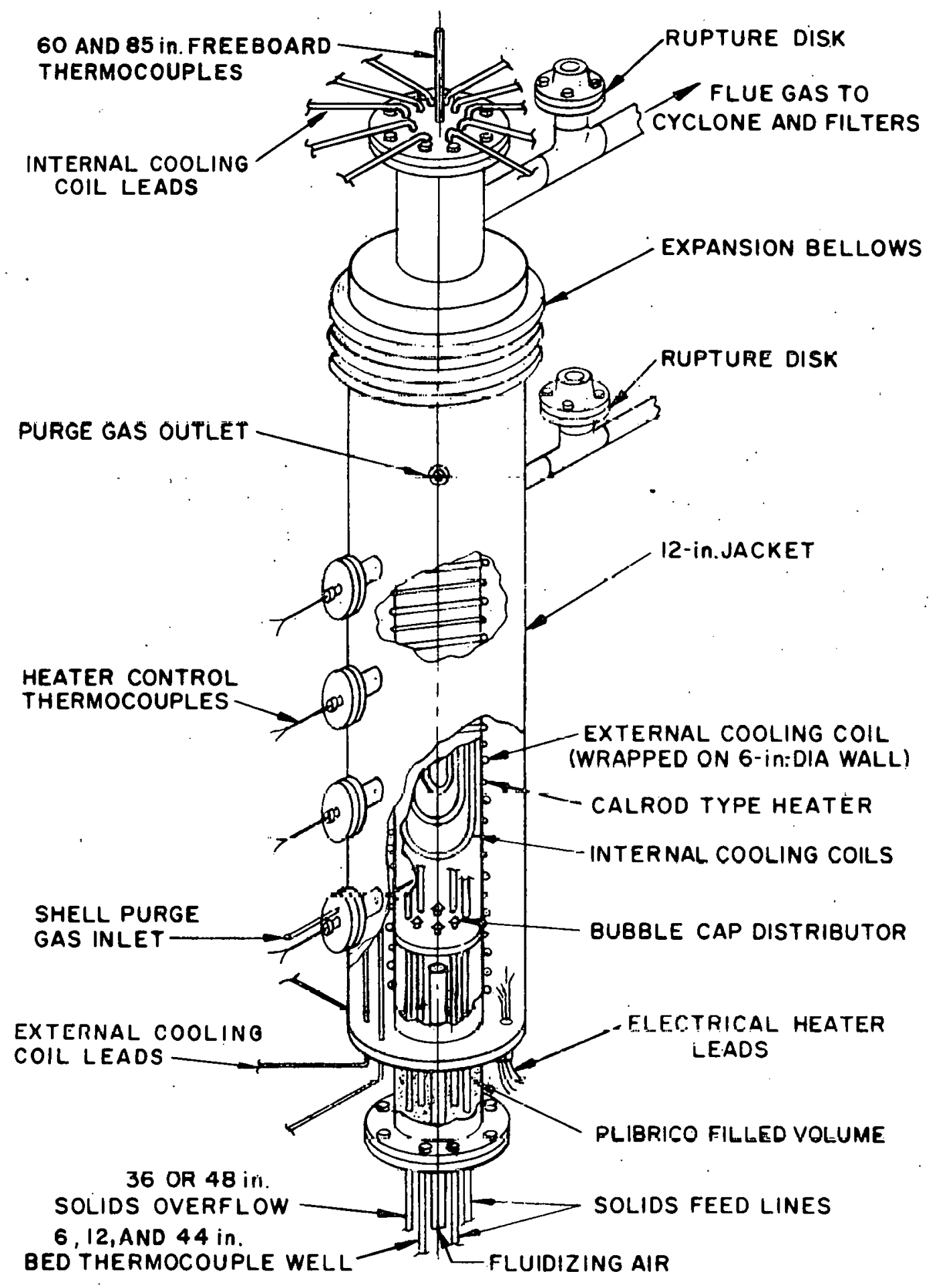

Figure 2. Detail Drawing of 6-in.-Dia, Pressurized Fluidized-Bed Combustor 
experiment, the response of each analytical instrument is checked using standard gas mixtures of flue-gas components in nitrogen. Batch samples of the flue gas can be taken and analyzed for components of secondary importance.

The combustion system is equipped with a Hewlett-Packard 2010C data acquisition system to monitor and record temperature, pressure, gas flow, and flue-gas concentration data for subsequent data handling and analysis.

\section{Experimental Procedure}

The experimental procedure, although subject to minor variations, was basically as follows. A preweighed amount ( $15 \mathrm{~kg}$ ) of either partially sulfated additive from a previous experiment or tabular alumina was charged to the reactor to provide an initial bed of material. The starting bed was then raised to about $800^{\circ} \mathrm{F}$ by passing fluidizing air, preheated to between 800 and $900^{\circ} \mathrm{F}$, through the combustor and simultaneously employing the resistance heaters on the combustor wall. Once the bed temperature reached $800^{\circ} \mathrm{F}$, the system was brought to the desired operating pressure and coal entrained in a transport air stream was injected into the bed. To prevent the possibility of carbon accumulation in the fluidized bed during startup, coal was initially injected in sma11, intermittent amounts until ignition and sustained combustion was confirmed by a rapidly increasing temperature and a changing flue-gas composition. Continuous injection of coal was then initiated and the bed temperature was raised to a selected combustion temperature. The bed temperature was maintained by use of the external and internal cooling coils.

Injection of the sulfur-accepting additive was initiated when the bed reached operating temperature. The air, coal, and dolomite feed rates were adjusted to give a specified mole ratio of calcium in the additive to sulfur in the coal, a specified superficial gas velocity, and a specified level of oxygen in the flue gas leaving the combustor. Sulfated additive was removed from the combustor by means of a standpipe to maintain a constant fluidized-bed level.

\section{Combustion Experiments with Arkwright Coal}

A series of nine experiments in a $3 \times 3$ latin-square experimental design ( $1 / 3$ replicate of a $3^{3}$ factorial design) plus 2 replicate experiments were made to measure the effects of the independent operating variables, temperature, fluidizing-gas velocity, and $\mathrm{Ca} / \mathrm{S}$ mole ratio, on response variables such as sulfur dioxide capture efficiency, nitrogen oxide levels in the flue gas, additive utilization, additive entrainment and decrepitation, combustion efficiency, and heat-transfer coefficients. The three levels of the variables tested were (1) temperature at 1450,1550 , and $1650^{\circ} \mathrm{F}$; (2) Ca/S mole ratio at 1,2 , and 3 ; and (3) gas velocity at 2.0,3.5, and $5.0 \mathrm{ft} / \mathrm{sec}$. All of the experiments were made at a pressure of 8 atm absolute, a $3-\mathrm{ft}$ fluidized-bed height, 
and $3 \%$ oxygen in the flue gas. Table 1 sumarizes the designed operating conditions and shows the matrix representation for the eleven experiments in the experimental design. The actual operating conditions and flue-gas compositions for the eleven experiments are given in Table 2 .

Table 1. Designed Operating Conditions and Matrix Representation for the Eleven Experiments in the Latin-Square Experimental Design

\begin{tabular}{ll}
\hline Equipment: & 6-in.-dia pressurized fluidized-bed combustor \\
Coal: & Arkwright (Consolidation Coal Company) \\
Additive: & Tymochtee dolomitc (C. E. Duff and Sons) \\
Pressure: & $8 \mathrm{~atm}$ abs \\
Fluidized-Bed Height: & $3 \mathrm{ft}$ \\
Excess A1r: & $.15 \%\left(3 \% \mathrm{U}_{2}\right.$ in the dry tlue gas) \\
&
\end{tabular}

Levels of Independent Variables

Variable Leve1 1 Level 2 Level 3

(T) Temperature, ${ }^{\circ} \mathrm{F}$ 1450 1.0 1550 1650

(R) $\mathrm{Ca} / \mathrm{S}$ Mole Ratio

2.0

2.0 3.0

(V) Gas Velocity, ft/sec

3.5

5.0

Matrix Representation of Experimental Combinations

\begin{tabular}{c|c|c|c|}
$\mathrm{T}_{1}$ & $\mathrm{~T}_{1}$ & $\mathrm{~T}_{3}$ \\
\cline { 2 - 3 } & $\begin{array}{c}\mathrm{T}_{2} \\
(\mathrm{VAR}-5)^{\mathrm{a}}\end{array}$ & $\begin{array}{c}\mathrm{V}_{1} \\
(\mathrm{VAR}-3)\end{array}$ & $\begin{array}{c}\mathrm{V}_{3} \\
(\mathrm{~V} A \mathrm{R}-9) \\
\mathrm{R}_{2}\end{array}$ \\
\hline $\begin{array}{c}\mathrm{V}_{3} \\
(\mathrm{VAR}-7)\end{array}$ & $\begin{array}{c}\mathrm{V}_{2} \\
(\mathrm{VAR}-6)\end{array}$ & $\begin{array}{c}\mathrm{V}_{1} \\
(\mathrm{VAR}-4)\end{array}$ \\
\hline $\mathrm{R}_{3}$ & $\begin{array}{c}\mathrm{V}_{3} \\
(\mathrm{VAR}-2)\end{array}$ & $\begin{array}{c}\mathrm{V}_{2} \\
(\mathrm{VAR}-8)\end{array}$ \\
\hline
\end{tabular}

\footnotetext{
axperiment number.

${ }^{b}$ Two replicate experiments made of this experimental combination; VAR-6-R, VAR-6-2R.
} 
Table 2. Operating Conditions and Flue-Gas Analyses for the Eleven Experiments Investigating the Effects of Independent Operating Variables

\begin{tabular}{|c|c|c|c|c|c|c|c|c|}
\hline \multirow[b]{3}{*}{ Experiment } & \multirow{3}{*}{$\begin{array}{l}\text { Combustion } \\
\text { Temp, }{ }^{\circ} \mathrm{F}\end{array}$} & \multirow{3}{*}{$\begin{array}{r}\begin{array}{r}\text { Fluidized } \\
\text { Syst }\end{array} \\
\begin{array}{c}\text { Ca/S Mole } \\
\text { Ratio }\end{array}\end{array}$} & $\begin{array}{r}\text { Coal: } \\
\text { Additive: } \\
\text { Bed Height: } \\
\text { m Pressure: }\end{array}$ & $\begin{array}{l}\text { Arkwr } \\
\text { Tymoct } \\
3 \mathrm{ft} \\
8 \mathrm{~atm}\end{array}$ & $\begin{array}{l}\text { ght }(2 \text {. } \\
\text { tee Dol } \\
\text { abs }\end{array}$ & $\begin{array}{l}2 \% \text { sulfur } \\
\text { mite }\end{array}$ & & \\
\hline & & & \multirow{2}{*}{$\begin{array}{c}\text { Gas } \\
\text { Velocity, } \\
\text { ft/sec }\end{array}$} & \multicolumn{5}{|c|}{ Flue-Gas Analysis ${ }^{a}$} \\
\hline & & & & $0_{2}, \%$ & $\mathrm{CO}_{2}, \%$ & $\mathrm{SO}_{2}, \mathrm{ppm}$ & $\mathrm{NO}, \mathrm{ppm}$ & $\mathrm{CO}, \mathrm{ppm}$ \\
\hline VAR-1 & 1445 & 2.9 & 2.1 & 2.7 & 17 & 120 & 190 & 100 \\
\hline VAR-2 & 1565 & 2.9 & 4.8 & 3.0 & 17 & 130 & 210 & 30 \\
\hline VAR-3 & 1575 & 1.1 & 2.1 & 3.0 & 15 & 350 & 140 & 30 \\
\hline VAR-4 & 1650 & 1.9 & 2.3 & 3.0 & 16 & 120 & 180 & 50 \\
\hline VAR-5 & 1460 & 1.0 & 3.4 & 3.0 & 15 & 680 & 150 & 7.60 \\
\hline VAR-6 & 1565 & 2.0 & 3.6 & 3.0 & 16 & 170 & 190 & 30 \\
\hline VAR-6-R & 1560 & 2.1 & 3.6 & 2.9 & 15 & 210 & 180 & 30 \\
\hline VAR-6-2R & 1550 & 2.0 & 3.5 & 3.0 & 16 & 190 & 160 & 30 \\
\hline VAR- 7 & 1460 & 2.2 & 4.2 & 2.7 & 16 & 260 & 150 & 90 \\
\hline VAR-8 & 1630 & 3.2 & 3.6 & 3.0 & 17 & 130 & 270 & 40 \\
\hline VAR-9 & 1665 & 1.0 & 4.9 & 2.9 & 16 & 850 & 120 & 40 \\
\hline
\end{tabular}

ary basis. 
Sulfur Dioxide Retention. Sulfur dioxide levels in the flue gas ranged from $850 \mathrm{ppm}$ at a Ca/S mole of 1.0 , gas velocity of $4.9 \mathrm{ft} / \mathrm{sec}$, and bed temperature of $1665^{\circ} \mathrm{F}$ to a low of $120 \mathrm{ppm}$ at a Ca/s mole ratio of 2.9 , gas velocity of $2.1 \mathrm{ft} / \mathrm{sec}$, and bed temperature of $1445^{\circ} \mathrm{F}\left(\mathrm{SO}_{2}\right.$ level at zero removal is about $2300 \mathrm{ppm}$ ). These sulfur dioxide levels correspond, respectively, to emission rates of 1.57 and $0.23 \mathrm{lb} \mathrm{s0} \mathrm{S}_{2} / 10^{6}$ $\mathrm{BTU}$ as compared with the EPA emission standard of $1.2 \mathrm{lb} \mathrm{SO}_{2} / 10^{6} \mathrm{BTU}$.

\section{Analysis of Variance of $\mathrm{SO}_{2}$ Data. An analysis of variance was} made on the $\mathrm{SO}_{2}$ levels in the flue gas and is presented in Table 3.

According to the F-test for significance at the $\alpha=0.1$ level, the $\mathrm{Ca} / \mathrm{S}$ mole ratio is the only significant source of variation in the observed experimental $\mathrm{SO}_{2}$ levels. However, the validity of the analysis of variance for the latin square experimental design (essentially a one-third replicate of a $3^{3}$ factorial design which does not confound main effects with each other) is based on the assumption that the controlled variables act independently of one another. This is expressed mathematically by the model equation for the latin square experimental design as follows:

$$
x_{i j k}=\mu+\alpha_{i}+\beta_{j}+\gamma_{k}+\varepsilon_{i j k}
$$

where $X_{i j k}$ denotes the observed response, $\mu$ equals the true mean of all possible responses, $\alpha_{i}, \beta_{j}$, and $\gamma_{k}$ equal the true treatment effects, and $\varepsilon_{i j k}$ equals the residual or error between the observed response and the expected response.

Table 3. Analysis of Variance of $\mathrm{SO}_{\text {? }}$ Flue-Gas Levels in the $3 \times 3$ Latin-Square Designed Series of "VAR" Experiments

\begin{tabular}{|c|c|c|c|c|c|}
\hline $\begin{array}{l}\text { Source of } \\
\text { Variation }\end{array}$ & $\begin{array}{l}\text { Sum of } \\
\text { Squares }\end{array}$ & $\begin{array}{c}\text { Degrees of } \\
\text { Freedom }\end{array}$ & $\begin{array}{l}\text { Mean } \\
\text { Square }\end{array}$ & $\mathrm{F}_{\mathbf{e}^{\mathrm{a}}}^{\mathrm{a}}$ & $\mathrm{F}_{0.1}$ \\
\hline $\begin{array}{l}\text { Ca/S Ratio } \\
\text { Velocity } \\
\text { Temperature } \\
\text { Error }\end{array}$ & $\begin{array}{l}4.434 \times 10^{5} \\
7.120 \times 10^{4} \\
3.780 \times 10^{4} \\
2.80 \times 10^{4}\end{array}$ & $\begin{array}{l}2 \\
2 \\
2 \\
2\end{array}$ & $\begin{array}{l}2.217 \times 10^{5} \\
3.56 \times 10^{4} \\
1.89 \times 10^{4} \\
1.40 \times 10^{4}\end{array}$ & $\begin{array}{r}15.8 \\
2.5 \\
1.4\end{array}$ & 9.00 \\
\hline Total & $5.804 \times 10^{5}$ & 8 & & & \\
\hline
\end{tabular}

${ }^{a_{F}}{ }_{e}=$ ratio of variable mean square to the error mean square. 
In practice, the assumption of independence is generally taken to mean that the interactions are not large compared to the main effects. When interactions are large, in addition to inflating the experimental error mean square, they confuse the effects required to be estimated and can give misleading F-tests for significance. Evidence that the error mean square has been inflated in the analysis of variance for the $\mathrm{SO}_{2}$ data is apparent in comparing the error mean square in the analysis of variance table $\left(1.4 \times 10^{4}\right)$ to the $\mathrm{SO}_{2}$ variance determined from the replicated experiments $\left(4.0 \times 10^{2}\right)$. Since both are estimates for $\sigma^{2}$, the variance of the response data, the difference between the two values seems large. The large error mean square in the analysis of variance table seems to indicate that interactions may be relatively large and that the model equation for the latin square analysis of variance does not hold for the $\mathrm{SO}_{2}$ data.

Regression Analysis of $\mathrm{SO}_{2}$ Data. Using nonlinear regression methods, the $\mathrm{SO}_{2}$ levels in the flue gas were correlated using the following power-curve-type equation:

$$
\ln \mathrm{SO}_{2}=\mathrm{A}+\mathrm{B}\left(\frac{\mathrm{V}^{1 / 2}}{\mathrm{RT}}\right)
$$

Where $\mathrm{SO}_{2}=$ level of $\mathrm{SO}_{2}$ observed in the flue gas, ppm $\mathrm{A}, \mathrm{B}=$ constants

$\mathrm{V}=$ superficial fluidizing-gas velocity, $\mathrm{ft} / \mathrm{sec}$

$\mathrm{R}=\mathrm{Ca} / \mathrm{S}$ mole ratio

$\mathrm{T}=$ Bed cemperature, ${ }^{\circ} \mathrm{R} \times 10^{-3}$

The values of the coefficients $A$ and $B$ were determined by the method of least squares to be $4.06 \pm 0.06$ and $2.53 \pm 0.10$, respectively. The nominal or designed levels of the independent operating variables were used for the correlation.

In Table 4, the calculated and experimental values for the eleven experiments in the "VAR" series are presented for comparison. Examination of the residuals indicates an excellent correlation of the data with the empirical equation. It should be emphasized that the correlation equation is not represented as a functional explanation for the dependence of the $\mathrm{SO}_{2}$ flue-gas concentration on the operating parameters.

Figures 3, 4, and 5 illustrate, respectively, the effect of $\mathrm{Ca} / \mathrm{S}$ mole ratio, superficial fluidizing-gas velocity, and bed temperature on the $\mathrm{SO}_{2}$ flue-gas concentration. The solid lines in the figures are based on the empirical correlation of the data given above. The experimental data, corrected where necessary for the effect of the third independent variable, are plotted along with the correlation curves. For $\mathrm{Ca} / \mathrm{S}$ ratios above 2.0 , the $\mathrm{SO}_{2}$ removal is generally greater than $90 \%$. The level of $\mathrm{SO}_{2}$ in the flue gas increases rapidly, however, with decreasing $\mathrm{Ca} / \mathrm{S}$ ratio and with increasing gas velocity at low $\mathrm{Ca} / \mathrm{S}$ ratios. The combustion temperature appears to have very little effect over the range of conditions investigated. This is 
considerably different from the temperature effect observed in atmospheric-pressure combustion experiments which showed a maximum sulfur dioxide removal (hence a minimum sulfur dioxide level) at a combustion temperature of $1550^{\circ} \mathrm{F} .{ }^{1}$

Table 4. Comparison Between Experimental and Calculated Values for the $\mathrm{SO}_{2}$ Flue-Gas Levels in the "VAR" Experiments

\begin{tabular}{llcr} 
& \multicolumn{2}{c}{$\begin{array}{l}\text { Levels of } \mathrm{SO}_{2} \text { in } \\
\text { the Flue } \mathrm{Gas}_{\text {PPm }}\end{array}$} & \\
\cline { 2 - 4 } Experiment & Experimental & Calculated & Residual \\
\hline & & & \\
VAR-1 & 118 & 1.10 & -8 \\
VAR-2 & 129 & 145 & 16 \\
VAR-3 & 351 & 340 & -11 \\
VAR-4 & 122 & 135 & 13 \\
VAR-5 & 681 & 690 & 9 \\
VAR-6 & 169 & 185 & 16 \\
VAR-7 & 262 & 255 & -7 \\
VAR-8 & 131 & 120 & -11 \\
VAR-9 & 846 & 845 & -1 \\
VAR-6-R & 209 & 185 & -24 \\
VAR-6-2R & 190 & 185 & -5 \\
\hline
\end{tabular}

The results indicate that for this coal and additive it should be possible to operate close to a $\mathrm{Ca} / \mathrm{S}$ mole ratio of 1.0 and still meet the EPA emissions limitation of $1.21 \mathrm{~b}$ of sulfur dioxide per $10^{6}$ b'l'U. It should be emphasized, however, that the effects reported here are based on a minimum number of observations. Since the sulfur dioxide level in the flue gas is so highly responsive between a $\mathrm{Ca} / \mathrm{S}$ mole ratio of 1.0 and 2.0 , additional data in this range are needed to provide a greater degree of reliability to the effects observed abnve.

Kinetics of $\mathrm{SO}_{2}$ Retention. The pronounced effect of the $\mathrm{Ca} / \mathrm{S}$ mole ratio on the $\mathrm{SO}_{2}$ flue-gas concentration (Fig. 3) suggests that the rate of $\mathrm{SO}_{2}$ uptake by the additive is diffusion limited. At high $\mathrm{Ca} / \mathrm{S}$ ratios ( 22.0 ), sufficient additive surface area is available for high $\mathrm{SO}_{2}$ removal ( $290 \%$ or better). As the $\mathrm{Ca} / \mathrm{S}$ ratio approaches unity, however, diffusion of reactants and products to and from the internal surfaces of the additive particle becomes increasingly important for high removal rates. The relatively poor removal rates obtained at a $\mathrm{Ca} / \mathrm{S}$ mole ratio of 1.0 suggest, therefore, a diffusionlimited process.

Examination of Fig. 4 also supports the theory that the $\mathrm{SO}_{2}$ dolomite reaction is diffusion limited. In a diffusion-controlled 


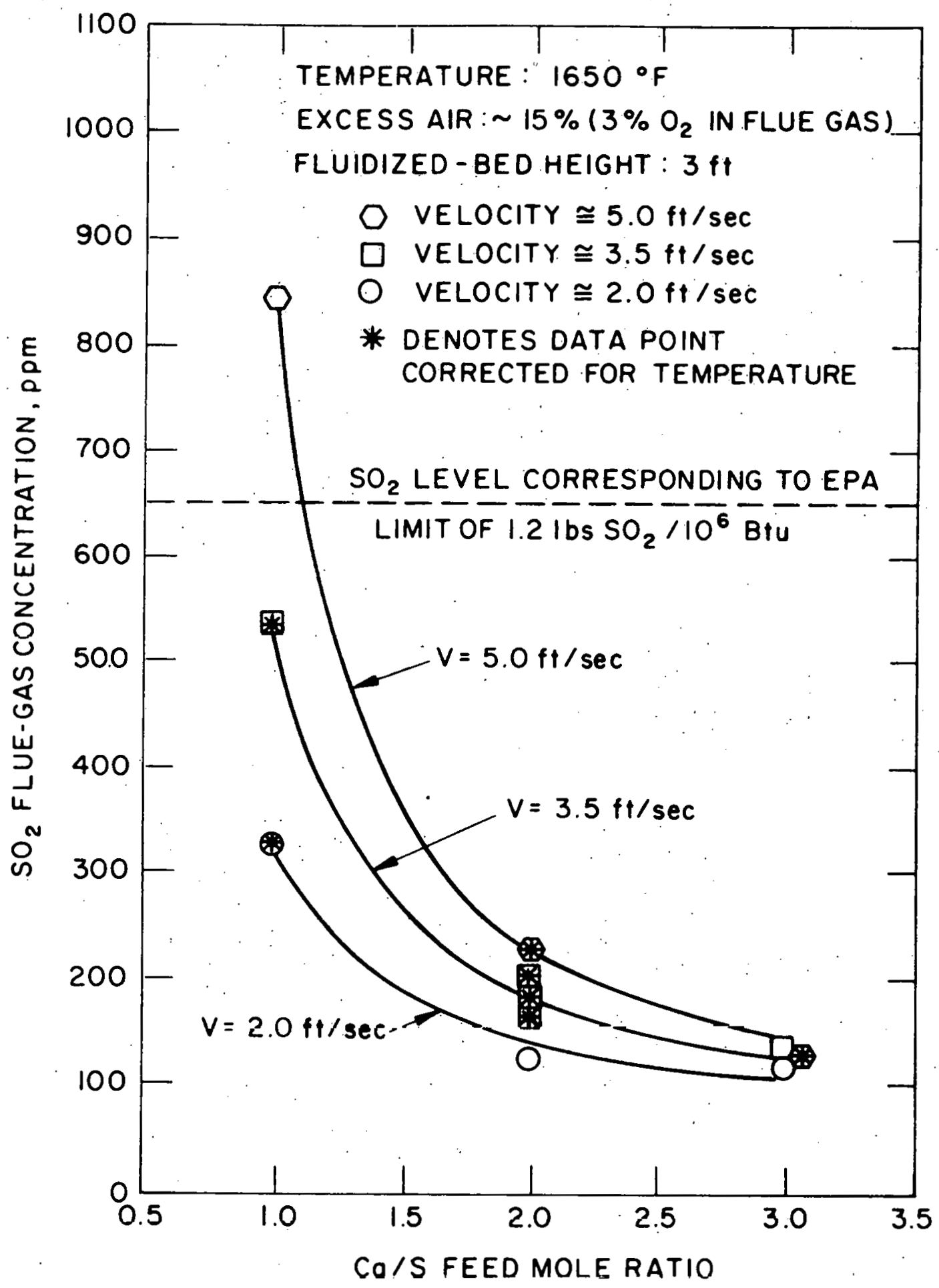

Figure 3. Effect of $\mathrm{Ca} / \mathrm{S}$ Mole Ratio on $\mathrm{SO}_{2}$ Level in Flue Gas 


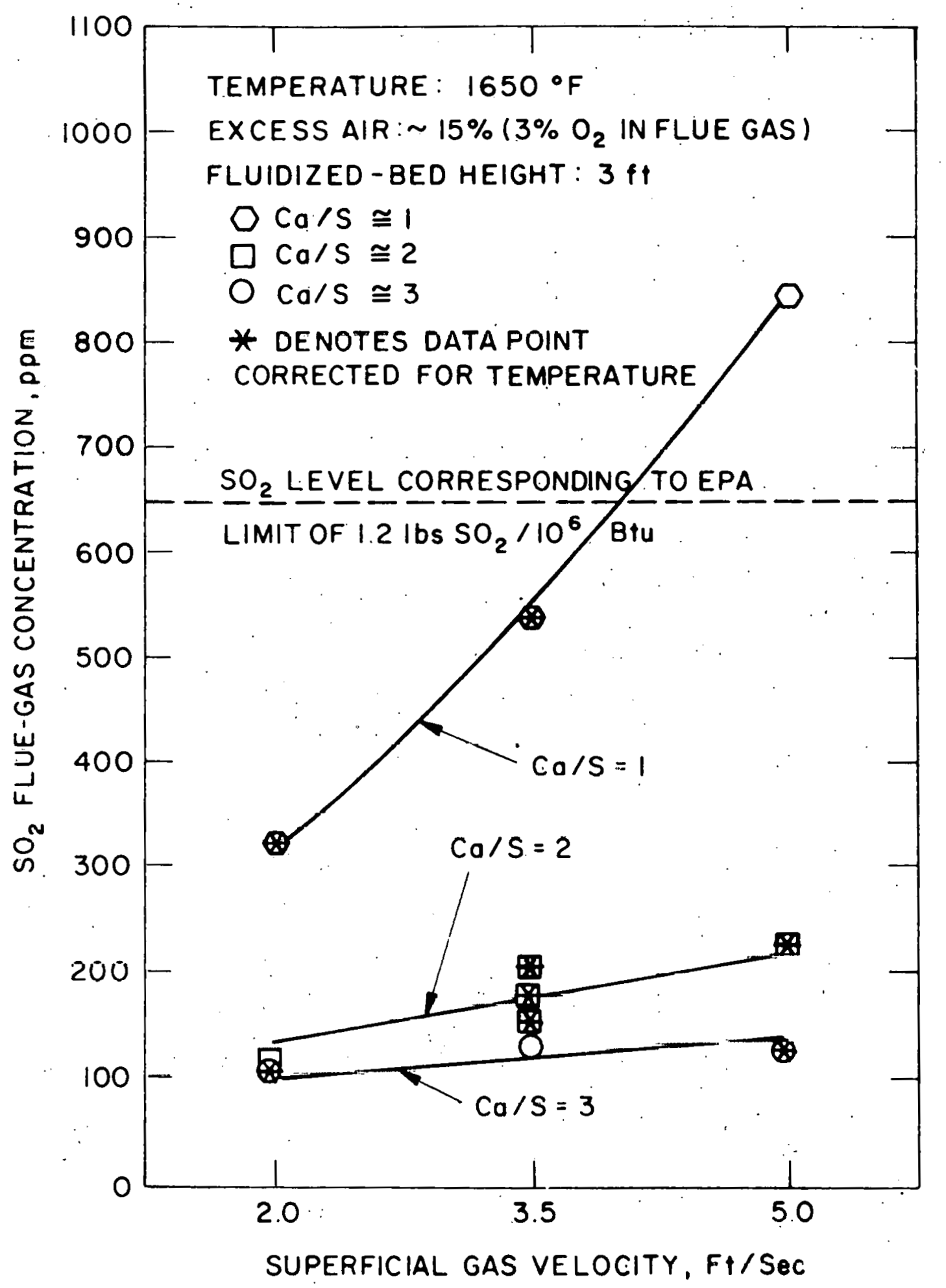

Figure 4. Effect of Superficial Gas Velocity on $\mathrm{SO}_{2}$ Level in Flue Gas 


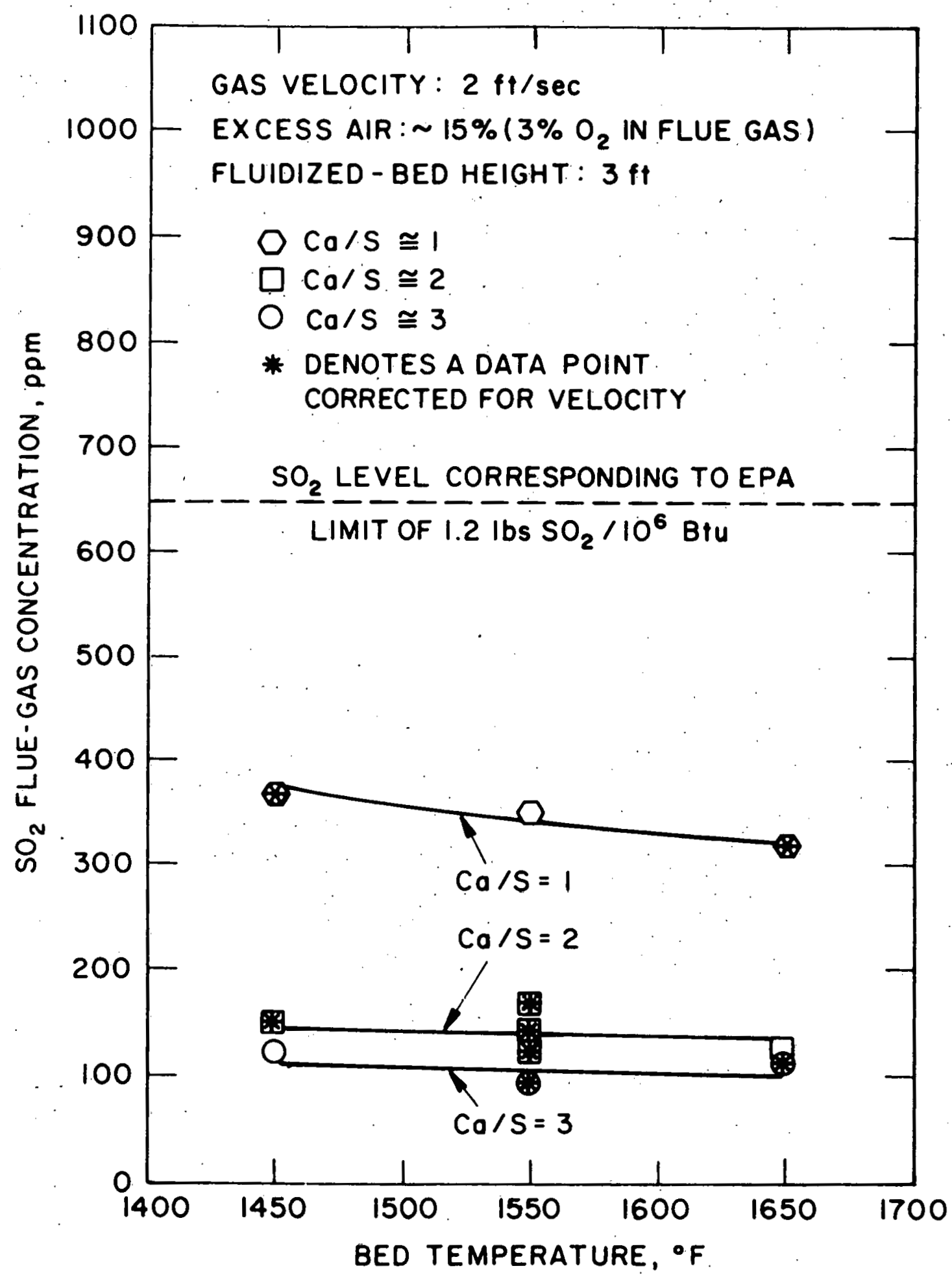

Figure 5. Effect of Bed Temperature on $\mathrm{SO}_{2}$ Level in Flue Gas 
situation, the smaller particles are more reactive than the larger particles because of their significantly greater external surface area per unit mass. Increasing the superficial, fluidizing-gas velocity through the bed in effect reduces the reactor residence time of the smaller, more reactive particles by increasing the rate of their elutriation from the reactor. At the high $\mathrm{Ca} / \mathrm{S}$ ratios, loss of the finer particles is less significant because of the relatively large quantity of dolomite available to react with the sulfur. At the lower $\mathrm{Ca} / \mathrm{S}$ ratio of 1.0 , however, the loss of the finer, more reactive particles becomes more noticeable.

The relatively small effect of temperature on the $\mathrm{SO}_{2}$ removal, as shown in Fig. 5, again suggests a diffusion-controlled process. Reaction-controlled processes should show a strong temperature dependence.

Nitrogen Oxide Emissions. Nitrogen oxide levels in the flue gas were extremely low over the entirc rangc of operating conditions tested. Values ranged from $270 \mathrm{ppm}$ at a Ca/S mole ratio of 3.2 , combustion temperature of $1630^{\circ} \mathrm{F}$, and fluidizing-gas velocity of 3.6 $\mathrm{ft} / \mathrm{sec}$ to $120 \mathrm{ppm}$ at a Ca/S mole ratio of $\dot{1} .0$, temperature of $1665^{\circ} \mathrm{F}$, and veloctty of $4.9 \mathrm{ft} / \mathrm{sec}$. These nitrogen oxide concentrations correspond, respectively, to emissions of 0.40 and $0.151 \mathrm{~b} \mathrm{NO} \mathrm{N}_{2} / 10^{6}$ BTU, as compared with the EPA emission standard of $0.701 \mathrm{~b} \mathrm{NO} \mathrm{N}_{2} / 10^{6}$ BTU.

An analysis of variance was made for the No data as for the $\mathrm{SO}_{2}$ data, and is presented in lable 5. The only apparently significant effect on the No level in the flue gas was the $\mathrm{Ca} / \mathrm{S}$ ratio. It would appear from the analysis of variance that the problem of interaction between the independent operating variables was not as serious as in the analysis of variance for the $\mathrm{SO}_{2}$ data. The error mean square of 412 compares well with the variance of 272 determined for the No data from the three replicate experiments.

Table 5. Analysis of Variance of NO Flue-Gas Levels in the 3 × 3 Latin-Square Designed Series of "VAR" Experiments

\begin{tabular}{|c|c|c|c|c|c|}
\hline $\begin{array}{l}\text { Source of } \\
\text { Variation }\end{array}$ & $\begin{array}{l}\text { Sum of } \\
\text { Squares }\end{array}$ & $\begin{array}{c}\text { Degrees of } \\
\text { Freedum }\end{array}$ & $\begin{array}{l}\text { Mean } \\
\text { Square }\end{array}$ & $\mathrm{F}_{\mathrm{e}}$ & $F_{0.1}$ \\
\hline $\mathrm{Ca} / \mathrm{S}$ Ratio & 11,494 & 2 & 5,747 & 13.9 & 9.00 \\
\hline Temperature & 1,425 & 2 & 712 & 1.7 & \\
\hline Velocity & 2,627 & 2 & 1,314 & 3.2 & \\
\hline Error & 823 & 2 & 412 & & \\
\hline Total & 16,369 & 8 & & & \\
\hline
\end{tabular}


In Fig. 6, the experimental values of the nitrogen oxide levels in the flue gas are plotted as a function of the $\mathrm{Ca} / \mathrm{s}$ mole ratio. The broken lines in Fig. 6, which connect data from experiments performed under nominally similar combustion temperatures, suggest a possible temperature dependence, but the results are inconclusive on that point. The observed correlation with $\mathrm{Ca} / \mathrm{S}$ mole ratio is consistent with the reported correlation of NO with $\mathrm{SO}_{2}$ levels during fluidizedbed combustion. Reduced mole ratios of $\mathrm{Ca} / \mathrm{S}$ correspond to high levels of $\mathrm{SO}_{2}$ in the fluidized bed of partially sulfated additive, which in turn has been shown to correspond with low No levels in the fluegas. 2,3

The nitrogen oxide levels reported here for combustion at 8 atm are considerably below the 300 to $550 \mathrm{ppm}$ values previously obtained during atmospheric combustion studies. 1 The pressure effect on nitrogen oxide emissions has been observed by other investigators. 4

Combustion Efficiency. Combustion efficiencies, expressed as the percentage of the total combustible carbon fed to the combustor that was converted to carbon dioxide, have been determined for the eleven experiments in the combustor variable study. Results of the calculations are listed in Table 6.

Combustion efficiencies for the eleven experiments ran from 88 to $97 \%$. In the analysis of variance, combustion temperature was the only variable indicated to have a significant effect at the $\alpha=0.1$ level. At a given gas velocity, the data indicate that the combustion efficiency increases with increasing temperature. The only anomaly in the combustion efficiency data is the low value of $91 \%$ for Experiment VAR-9. A value nearer $95 \%$ or $96 \%$ for this particular experiment would have been more.consistent with the other values reported.

The data also suggest that, at a given temperature, the combustion efficiency may decrease slightly with increasing gas velocity. This can also be seen in Fig. 7, which graphically illustrates the temperature dependence of combustion efflclency. The spread of the data indicates that increasing the velocity may result in slightly lower combustion efficiencies at a given temperature, owing perhaps to slightly shorter hold-up times for the combustible material in the fluidized bed. If the effect is real, however, it was too small to be indicated as significant by the analysis of variance.

The combustion efficiencies reported here are comparable with previously reported efficiencies obtained for atmospheric combustion experiments. ${ }^{1}$ In the previuus experiments, an Illinois No. 6 coal. containing 4.5 wt \% sulfur was burned in a limestone bed at combustion temperatures between 1550 and $1650^{\circ} \mathrm{F}$, a fluidizing-gas velocity of $3 \mathrm{ft} / \mathrm{sec}$, excess oxygen in the flue gas between 2.0 and $3.0 \%$, and $\mathrm{Ca} / \mathrm{S}$ mole ratios between 0 and 4.2. Measured combustion efficiencies for those experiments ranged from 94 to $97 \%$. Whereas 10 to $20 \%$ of the 


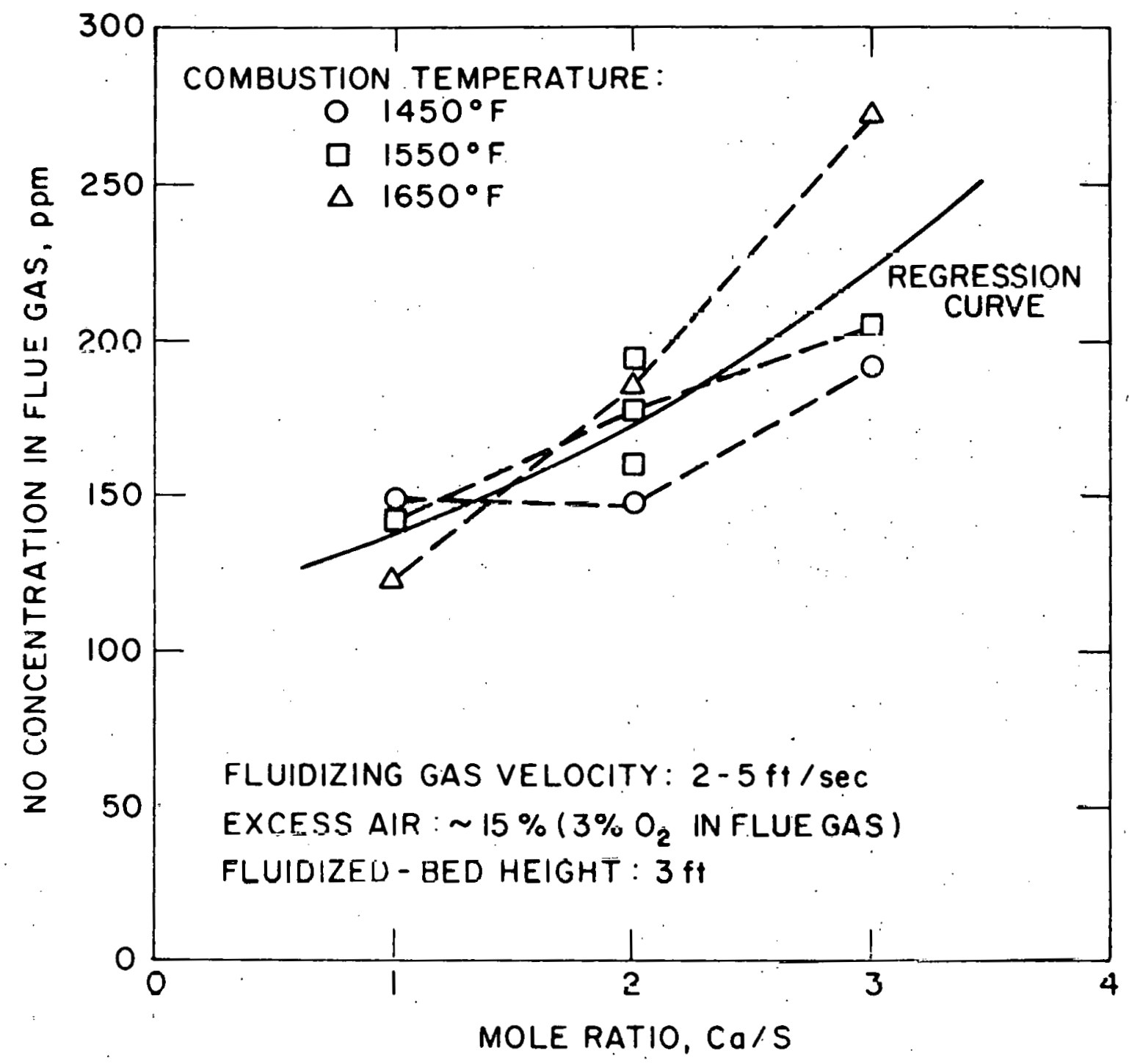

Figure 6, NO Concentration in Fluc Gas as a Function of $\mathrm{Ca} / \mathrm{S}$ Mole Ratio. 
Table 6. Combustion Efficiencies for "VAR"-Series Experiments

\begin{tabular}{|c|c|c|c|}
\hline \multirow[b]{2}{*}{ Experiment } & \multicolumn{2}{|c|}{ Nominal } & \multirow{2}{*}{$\begin{array}{c}\text { Combustion } \\
\text { Efficiency, } \\
\%\end{array}$} \\
\hline & $\begin{array}{c}\text { Bed Temp, } \\
{ }^{\circ} \mathrm{F}\end{array}$ & $\begin{array}{c}\mathrm{Ca} / \mathrm{S} \\
\text { Mole Ratio }\end{array}$ & \\
\hline Gas velocity, $2.0 \mathrm{ft} / \mathrm{sec}$ & & & \\
\hline $\begin{array}{l}\text { VAR-1 } \\
\text { VAR-3 } \\
\text { VAR-4 }\end{array}$ & $\begin{array}{l}1450 \\
1550 \\
1650\end{array}$ & $\begin{array}{l}3.0 \\
1.0 \\
2.0\end{array}$ & $\begin{array}{l}90 \\
96 \\
97\end{array}$ \\
\hline \multicolumn{4}{|l|}{ Gas velocity, $3.5 \mathrm{ft} / \mathrm{sec}$} \\
\hline $\begin{array}{l}\text { VAR-5 } \\
\text { VAR-6 } \\
\text { VAR-6-R } \\
\text { VAR-6-2R } \\
\text { VAR-8 }\end{array}$ & $\begin{array}{l}1450 \\
1550 \\
1550 \\
1550 \\
1650\end{array}$ & $\begin{array}{l}1.0 \\
2.0 \\
2.0 \\
2.0 \\
3.0\end{array}$ & $\begin{array}{l}89 \\
94 \\
94 \\
94 \\
96\end{array}$ \\
\hline \multicolumn{4}{|l|}{ Gas velocity, $5.0 \mathrm{ft} / \mathrm{sec}$} \\
\hline $\begin{array}{l}\text { VAR-7 } \\
\text { VAR-2 } \\
\text { VAR-9 }\end{array}$ & $\begin{array}{l}1450 \\
1550 \\
1650\end{array}$ & $\begin{array}{l}2.0 \\
3.0 \\
1.0\end{array}$ & $\begin{array}{l}88 \\
94 \\
91\end{array}$ \\
\hline
\end{tabular}

a Defined as the percentage of the total combustible carbon fed that was completely burned to $\mathrm{CO}_{2}$.

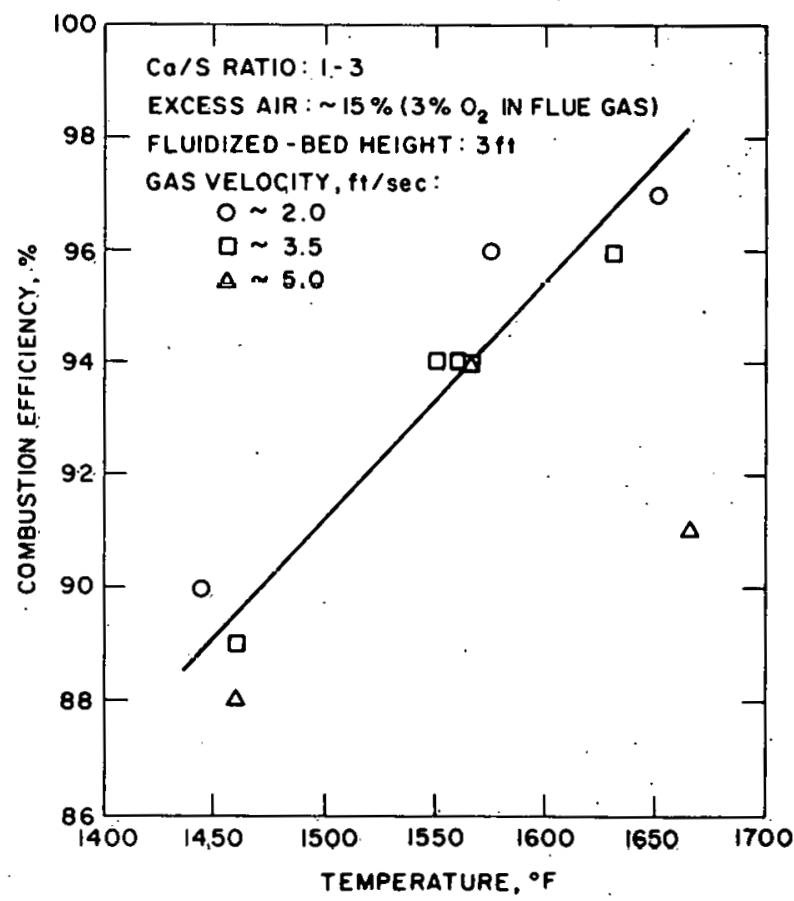

Figure 7. Combustion Efficiency as a Function of Bed Temperature 
unburned carbon was in the form of carbon monoxide and methane in the flue gas for the atmospheric pressure experiments, only 0.2 to $1.3 \%$ of the unburned carbon was present as carbon monoxide and methane in the flue gas for the experiments at $8 \mathrm{~atm}$. The major carbon loss in the tests at $8 \mathrm{~atm}$ occurred as the result of the elutriation of fine, unburned carbon particles from the fluidized bed.

In an application of the fluidized-bed combustion concept, the fly ash containing the unburned carbon will be fed to a second fluidized bed to complete the combustion. Earlier work has shown that combustion efficiencies of over $99 \%$ are then readily achieved. 5

Combustible Carbon Hold-up in the Fluidized Bed. Related to combustion efficiency is the combustible carbon hold-up in the fluidized bed. High carbon inventories in the fluidized bed could present highly unstable and hazardous operating conditions, particularly during start-up and shut-down of a unit.

To provide a measure of the combustible carbon hold-up in the fluidized bed during combustion, samples of the final bed material from the experiments in the variable study were analyzed for total carbon and for carbon present as carbonate ton. The combustible carbon content was taken as the difference between these two values. The results of these calculations are presented in Table 7 .

For the eleven experiments, the combustible carbon in the final bed material ranged from $<0.01$ to $1.60 \%$ and was $\leq 1.0 \%$ in seven of the experiments. These levels of carbon are sufficiently low to ensure safe, stable operating performance. The analysis of varlance Indicates no significant effects of the operating conditions on the combustible carbon levels in the final bed samples.

Additive Utilization. Of considerable economic importance is the level of additive utilization that can be achieved for a given sulfur removal. Additive utilization, or degree of sulfation, is defined as the percentage of the total moles of calcium in the additive converted to calcium sulfate. As the ratio of calcium in the additive to the sulfur in the coal decreases, the additive utilization increases. 'Ihis is accompanied, however, by a net decrease in the amount of sulfur retained by the additive and results in higher sulfur dioxide emissions. For the Arkwright coal, for example, the EPA emission standard requires approximately $71 \%$ sulfur removal. It should be theoretically possible, therefore, to meet the requirement.s using a $\mathrm{Ca} / \mathrm{S}$ ratio of 0.71 , assuming $100 \%$ utilization of the additive.

Table 8 lists the calculated calcium utilization values for the solid samples recovered from the bed, two cyclones, and a filter at the conclusion of each experiment. The entrained solid samples represent solids recovered from the flue gas during the entire experiment, including startup. The startup time was relatively short compared with the total time of the experiment, and run times were of 
Table 7. Combustible Carbon Content of Final Bed Material for "VAR"-Series Experiments

\begin{tabular}{|c|c|c|c|}
\hline \multirow[b]{2}{*}{ Experiment } & \multicolumn{2}{|c|}{ Nominal } & \multirow[b]{2}{*}{$\begin{array}{l}\text { Final Bed Com- } \\
\text { bustible Carbon, a } \\
\text { wt } \% .\end{array}$} \\
\hline & $\begin{array}{c}\text { Gas Velocity, } \\
\mathrm{ft} / \mathrm{sec}\end{array}$ & $\begin{array}{c}\mathrm{Ca} / \mathrm{S}, \text { mole } \\
\text { ratio }\end{array}$ & \\
\hline \multicolumn{4}{|c|}{ Bed temp, $1450^{\circ} \mathrm{F}$} \\
\hline $\begin{array}{l}\text { VAR-1 } \\
\text { VAR-5 } \\
\text { VAR-7 }\end{array}$ & $\begin{array}{l}2.0 \\
3.5 \\
5.0\end{array}$ & $\begin{array}{l}3.0 \\
1.0 \\
2.0\end{array}$ & $\begin{array}{r}0.60 \\
1.27 \\
<0.01\end{array}$ \\
\hline \multicolumn{4}{|c|}{ Bed temp, $1550^{\circ} \mathrm{F}$} \\
\hline $\begin{array}{l}\text { VAR-3 } \\
\text { VAR-6 } \\
\text { VAR-6-R } \\
\text { VAR-6-2R } \\
\text { VAR-2 }\end{array}$ & $\begin{array}{l}2.0 \\
3.5 \\
3.5 \\
3.5 \\
5.0\end{array}$ & $\begin{array}{l}1.0 \\
2.0 \\
2.0 \\
2.0 \\
3.0\end{array}$ & $\begin{array}{r}0.68 \\
1.60 \\
<0.01 \\
1.00 \\
1.30\end{array}$ \\
\hline \multicolumn{4}{|c|}{ Bed temp: $1650^{\circ} \mathrm{F}$} \\
\hline $\begin{array}{l}\text { VAR-4 } \\
\text { VAR-8 } \\
\text { VAR-9 }\end{array}$ & $\begin{array}{l}2.0 \\
3.5 \\
5.0\end{array}$ & $\begin{array}{l}2.0 \\
3.0 \\
1.0\end{array}$ & $\begin{array}{l}0.85 \\
0.36 \\
0.42\end{array}$ \\
\hline
\end{tabular}

Table. 8. Calcium Utilization ${ }^{a}$ in Solids Outlet Streams for the Combustion of Arkwright Coal in a Fluidized Bed of Tymochtee Dolomite

\begin{tabular}{lcccccc}
\hline & & & \multicolumn{4}{c}{ Calcium Utilization } \\
\cline { 5 - 7 } Experlutul & $\begin{array}{c}\text { Mole } \\
\text { Ratio }\end{array}$ & $\begin{array}{c}\text { Fluidization } \\
\text { Velocity, } \\
\text { ft/see }\end{array}$ & $\begin{array}{c}\text { Final } \\
\text { Bed, } \\
\%\end{array}$ & $\begin{array}{c}\text { Primary } \\
\text { Cyclone, } \\
\%\end{array}$ & $\begin{array}{c}\text { Secondary } \\
\text { Cyclone, } \\
\%\end{array}$ & $\begin{array}{c}\text { Filter, } \\
\%\end{array}$ \\
\hline VAR-1 & 2.9 & 2.1 & 37.2 & 34.9 & 52.6 & 93.7 \\
VAR-8 & 3.2 & 3.6 & 32.3 & 25.5 & 37.4 & 27.3 \\
VAR-2 & 2.9 & 4.8 & 34.1 & 30.1 & 47.9 & 50.0 \\
VAR-4 & 1.9 & 2.3 & 49.8 & 35.1 & 32.6 & 39.8 \\
VAR-6 & 2.0 & 3.6 & 41.3 & 37.9 & 56.5 & 75.0 \\
VAR-6-R & 2.0 & 3.6 & 49.7 & 41.7 & 62.5 & 82.0 \\
VAR-6-2R & 2.0 & 3.5 & 48.5 & 41.1 & 59.5 & 77.8 \\
VAR-7 & 2.2 & 4.2 & 47.3 & 39.0 & 37.5 & 46.5 \\
VAR-3 & 1.1 & 2.1 & 77.4 & 55.5 & 66.3 & 79.2 \\
VAR-5 & 1.0 & 3.4 & 76.5 & 56.9 & 65.2 & 77.8 \\
VAR-9 & 1.0 & 4.9 & 82.7 & 38.4 & 54.8 & 88.9 \\
\hline
\end{tabular}

aefined as the percentage of total moles of calcium present as $\mathrm{CaSO}_{4}$. ${ }^{b}$ In coal and additive feed streams. 
sufficient duration to allow for $\sim 80 \%$ bed replacement, assuming perfectly backmixed flow of additive through the combustor. The final bed samples, therefore, are fairly representative of steadystate conditions.

Examination of the data in Table 8 indicates that utflization of additive in the final bed material was affected inversely by the $\mathrm{Ca} / \mathrm{S}$ ratio and relatively unaffected by the fluidizing-gas velocity or bed termperature. This is graphically illustrated in Fig. 8, which depicts the sulfation of the final bed material as a function of the $\mathrm{Ca} / \mathrm{s}$ mole ratio. According to the analysis of variance, the effect of $\mathrm{Ca} / \mathrm{S}$ mole ratio on final bed utilization is highly significant at the $\alpha=0.005$ level.

It is interesting to notc, however, lhat the additive utilization was consistently higher for the final bed material than for the elutriated solids collected in the primary cyclone. In addition, calcium utillzation for elutriated solids generally increased the farther downstream the particulate matter was collected from the flue gas. This latter result is attributed to increasing reactivity with decreasing particle size of the particulate matter removed sequentially from the primary cyclone, the secondary cyclone, and the filter.

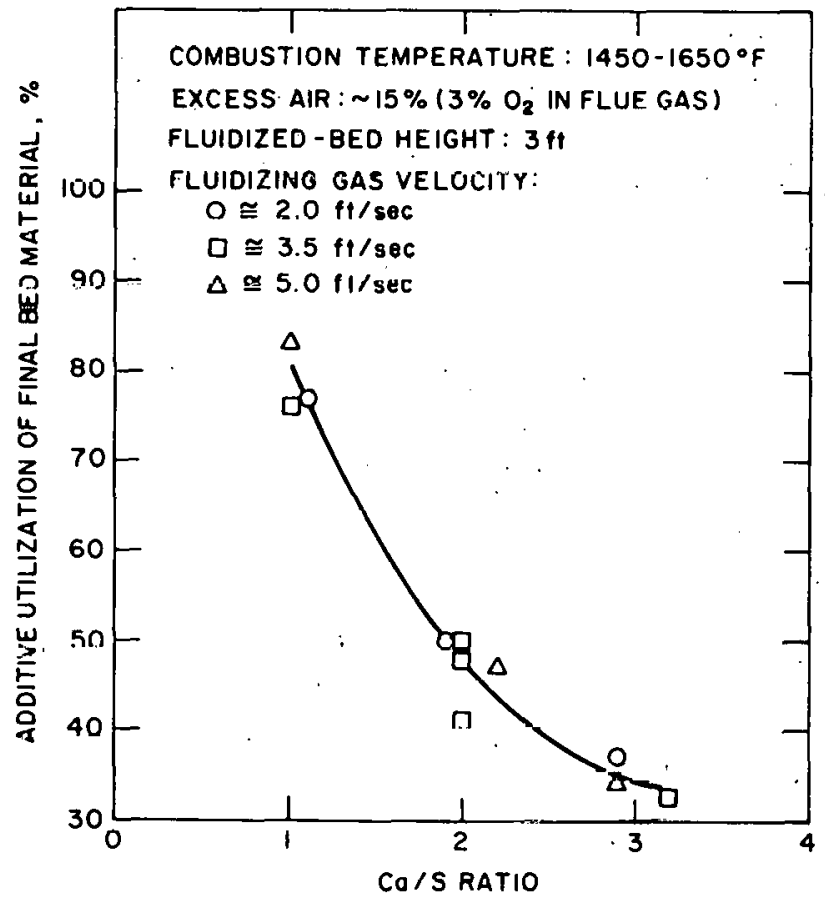

Figure 8. Additive Utilization of Final Bed Material as a Function of $\mathrm{Ca} / \mathrm{S}$ Mole Ratio 
Removal of Additive from Combustor by Elutriation. The results of the preceeding section on utilization indicate a definite advantage in minimizing the amount of additive leaving the combustor entrained in the flue gas. Not only is the utilization consistently higher for the additive in the fluidized bed (and hence for the additive leaving the combustor by overflow through the standpipe) than for the bulk of the entrained additive removed from the flue gas by the primary cyclone, but high additive entrainments may also present additional problems in flue-gas cleaning to meet the standards for particulate emissions. The two factors most strongly affecting elutriation of additive from the combustor are the gas velocity relative to the particle-size distribution of additive in the feed (terminal velocity effects) and the amount of decrepitation of additive that occurs during fluidization.

Terminal Velocities of Additive Particles. A theoretical consideration was made of the terminal velocities associated with different sized particles of additive. By means of a terminal-velocity correlation reported by Kunii and Levenspiel, 6 a series of curves was derived to illustrate the effect of system pressure (i.e., as it affects the density of the fluidizing gas), particle density, and particle sphericity on the relationship of particle size to its terminal velocity. The results of these calculations are presented in Fig. 9. The top curve relates the terminal gas velocity as a function of particle size for spheres having a particle density of $2.24 \mathrm{~g} / \mathrm{cm}^{3}$ (an approximate value for half-calcined dolomite). The fluidizing gas was considered to be at a temperature of $1800^{\circ} \mathrm{F}$ and a pressure of $1 \mathrm{~atm}$. At a fluidizing-gas velocity of $5 \mathrm{ft} / \mathrm{sec}$, no entrainment of +45 mesh solids would be expected. The lower curves, however, illustrate the effect of including a factor for the nonspherical nature or lack of sphericity of real particulate matter. By assuming a sphericity of 1.0 (true spheres), a typical flue-gas composition of the major components, a temperature of $1450^{\circ} \mathrm{F}$, and a pressure of $8 \mathrm{~atm}$, a set of curves was calculated for particle densities of 2.85 and $2.24 \mathrm{~g} / \mathrm{cm}^{3}$ (estimated range of density for half-calcined, partially sulfated dolomite). Again, little if any entrainment of +45 mesh additive would be expected at fluidizing velocities of only $5 \mathrm{ft} / \mathrm{sec}$. A repetition of the calculations for sphericities of 0.8 and 0.6 produced the lower two sets of curves. A sphericity of 0.6 or lower is common for crushed particulate materials. 6 At these lower values of sphericity, a fluidizing-gas velocity of $5 \mathrm{ft} / \mathrm{sec}$ is well above the terminal velocity required to entrain additive in the +45 mesh range. The two data points in Fig. 9 correspond to the maximum particle size of additive recovered from the primary cyclone for "VAR" experiments made at 2.1 and $4.9 \mathrm{ft} / \mathrm{sec}$. It would appear, therefore, that $80-90 \%$ of the dolomite used in the combustion experiments had a terminal velocity below $5 \mathrm{ft} / \mathrm{sec}$.

Experimental Elutriation Rates. On the basis of calcium material balances made for the experiments in the variable study, it was possible to calculate values for additive entrainment expressed as a percentage of the additive feed rate. In these experiments, the 


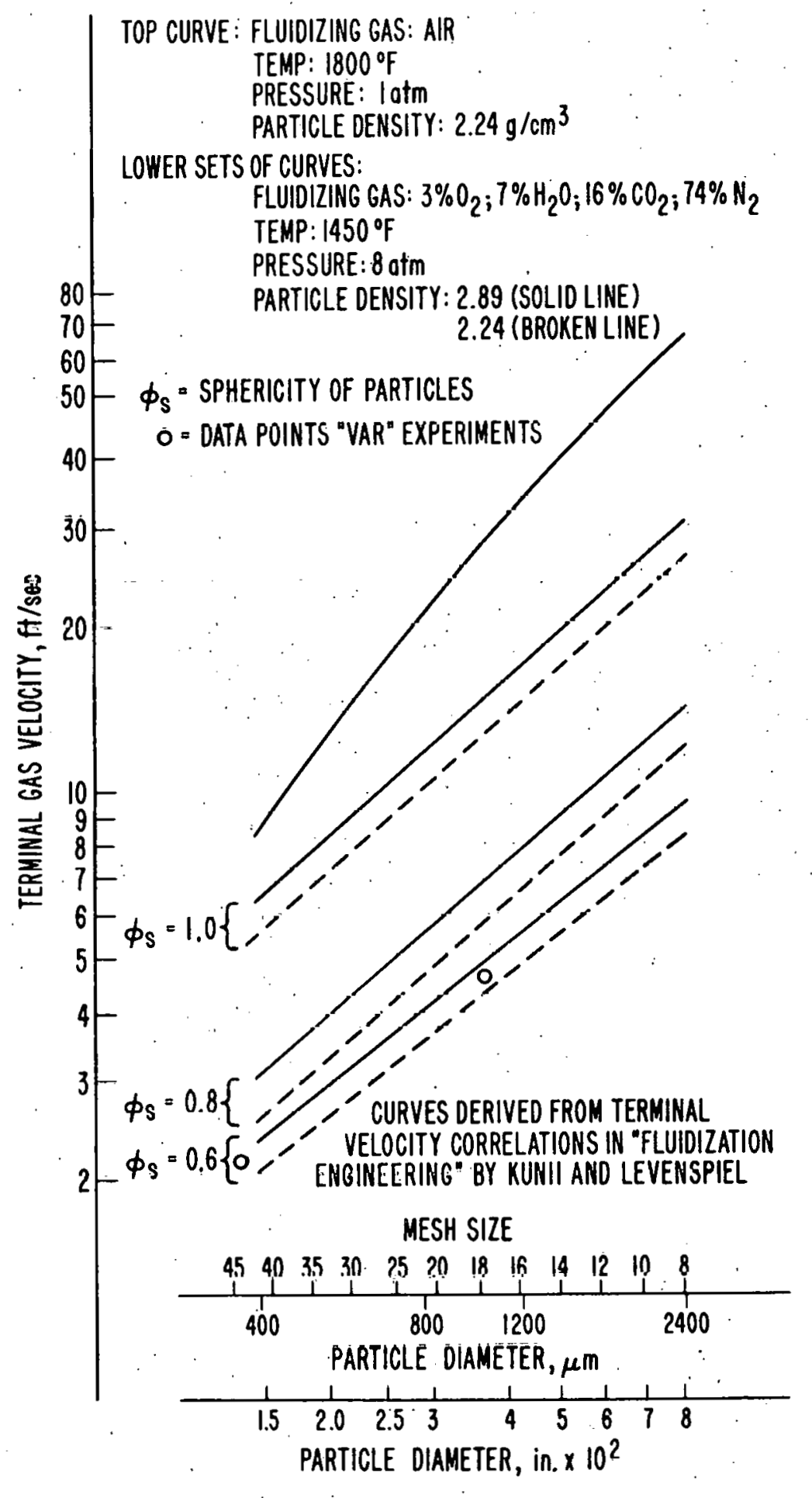

Figure 9. Terminal Gas Velocity of Solid Particles

in a Gas Flow as a Function of Particle Diameter for Various Physical Situations 
particle-size distribution of the dolomite fed to the combustor was held constant.

The results of the calculations are presented in Fig. 10, which depicts the relative rate of additive entrainment from the combustor as a function of the superficial-gas velocity. Entrainment of the additive increases rapidly from $25 \%$ at $2 \mathrm{ft} / \mathrm{sec}$ to as much as $80 \%$ entrainment at a velocity of $5 \mathrm{ft} / \mathrm{sec}$. The high elutriation rates at $5 \mathrm{ft} / \mathrm{sec}$ fluidization velocity are certainly in keeping with the theoretical terminal velocities of the dolomite particles.

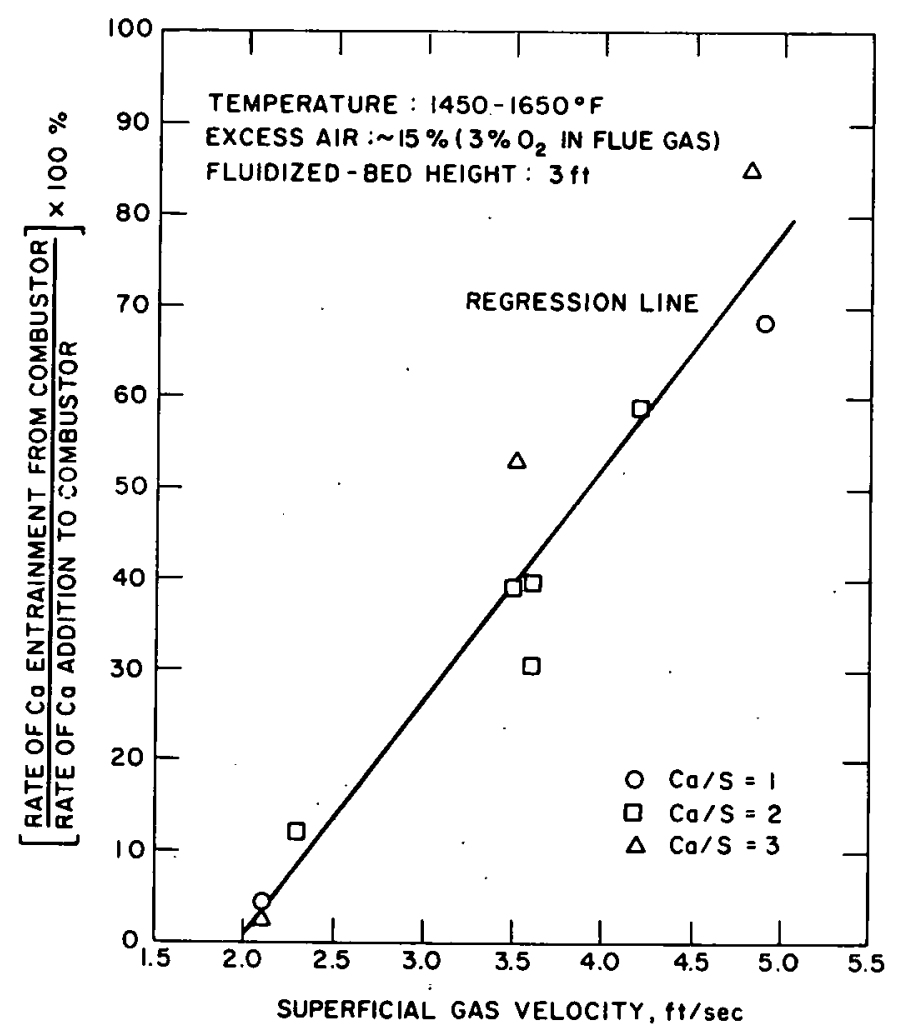

Figure 10. Entrainment of Sulfated Dolomite as a Function of Superficial Gas Velocity 
The data suggest that the inverse effect of velocity on sulfur removal is a result of the increased entrainment of additive at the higher velocities. We previously observed that velocity had no significant effect on the utilization of additive in the fluidized bed. It may be possible, therefore, to offset the inverse effect of velocity on sulfur retention by using a larger additive particle size at the higher velocities to reduce entrainment.

Decrepitation of Tymochtee Dolomite. A semi-quantitative at tempt was made to determine to what extent the high entrainments of additive reported above were the result of decrepitation of additive followed by elutriation of the resulting fines. The method chosen to provide a measure of additive decrepitation during a combustion experiment was to inventory the +45 mesh additive material (paillcle dlameter $>354 \mu \mathrm{m}$ ) entering and leaving the combustion system. $\Lambda$ more exacting or detailed analysis of decrepitation was hindered by the presence of fly ash in the entralned solids removed from the flue gas in the cyclone separators.

This is illustrated by a visual analysis of the different size cuts ( $+45,-100$ to +170 , and -325 mesh) of a typical primary cyclone product shown in the photograph of Fig. 11. The +45 mesh fraction of the product appears to be essentially free from fly ash and unburned carbonaceous materials. The two finer bize fractions, however, obviously contain considerable amounts of interfering ash and carbon. Chemical analysis of the +45 mesh material in F1g. 11 indicates a total carbon (from unburned carbon and $\mathrm{CaCO}_{3}$ ) of only $3.9 \%$. Chemical analysis of the unsplit material indicates a level of $4.1 \%$ carbon as carbonate in the additive. Thus, the +45 mesh fraction does not contain any significant levels of carbon or ash derived from the coal. Conversely, the $-100+170$ and -325 mesh fractions illustrated in Fig. 11 cuiilaln 36 and 20 wt \% rarbon, respectivcly, which iüulles a considerable carbon and ash content derived from the coal.

The screen-analyses data for the "VAR" experiments (tabulated in Appendix C) were used to inventory the +45 mesh additive entering and leaving the combustor. Weights of half-calcincd and partially sulfared additive were corrected on the basis of calcium-utilization data in Table 8 Lu the equivalent weight of fresh unreacted stone represented by the sample. An assumption made in the analysis was that the sixe of a particle does not change appreciably during calcination or sulfation. Minor changes in size would only affect the very small percentage of additive with a particle diameter at or near the $354 \mu \mathrm{m}$ cul polnt. The 145 mesh fraction, however, accounts for approximately 87 wt \% of the unreacted additive fed to the reactor.

The results of the calculations for the eleven experiments in the variable study are presented in Table.9. Additive recovery values determined by the above procedure ranged from 78 to $108 \%$ for the individual experiments. Average recoveries, however, calculated for each level of the three independent operating variables only ranged 
from 92 to $103 \%$ as compared with the average recovery of $96 \%$ for all the experiments. The data indicate that very little decrepitation of the additive occurs over the range of conditions tested.

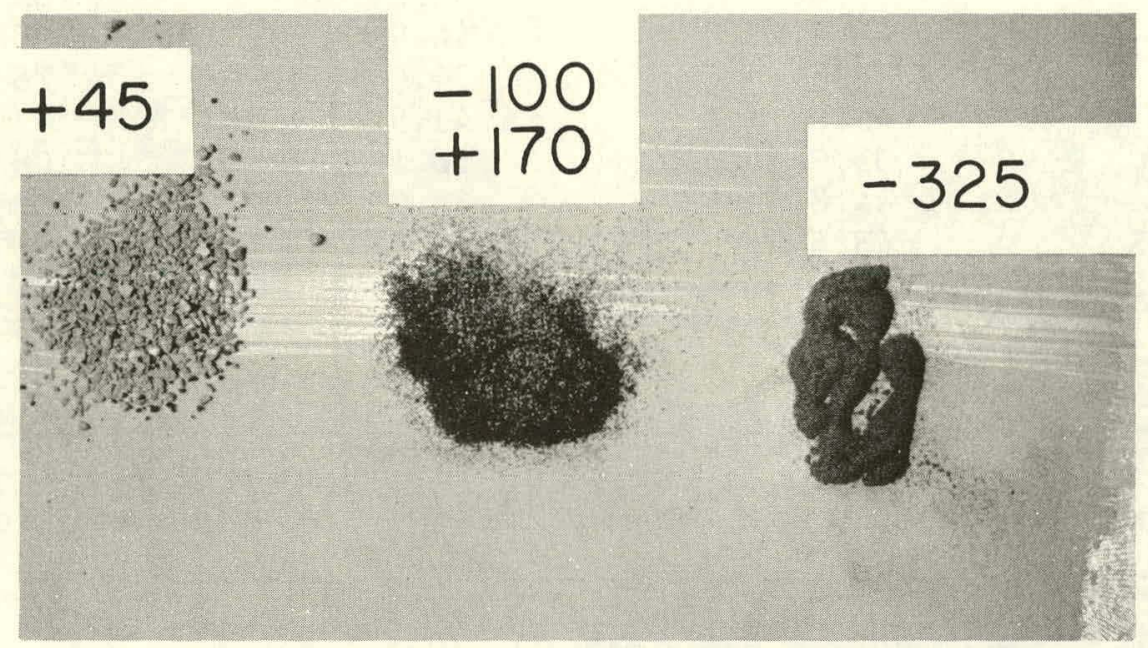

Figure 11. Various Size Fractions of Primary Cyclone Product Recovered during Combustion Experiment VAR-6-2R

Heat-Transfer Coefficients at the Combustor Wall. Values of heattransfer coefficients at the combustor wall have been determined for the eleven experiments in the statistically designed series of combustion experiments. Figure 12 illustrates the factors considered and the method used in the calculation of the coefficients. Using the notation given in Fig. 12, the amount of heat transferred through the reactor wall was determined by means of the equation.

$$
\mathrm{q}_{\mathrm{w}}=\left(\mathrm{q}_{\mathrm{r}}-\Delta \mathrm{H}_{\mathrm{r}}\right)-\left(\mathrm{q}_{\mathrm{i}}+\mathrm{q}_{\mathrm{g}}+\mathrm{q}_{\mathrm{o}}\right)
$$

The heat of reaction term, $\Delta \mathrm{H}_{\mathrm{r}}$, considers that the following reactions occur in the fluidized bed: combustion of coal, dissociation of dolomite, calcination of magnesium carbonate, and sulfation of calcium carbonate. 
Table 9. Inventory of +45 Mesh Additive Entering and Leaving the Combustion System for the Eleven Experiments in the "VAR" Series of Combustion Experiments

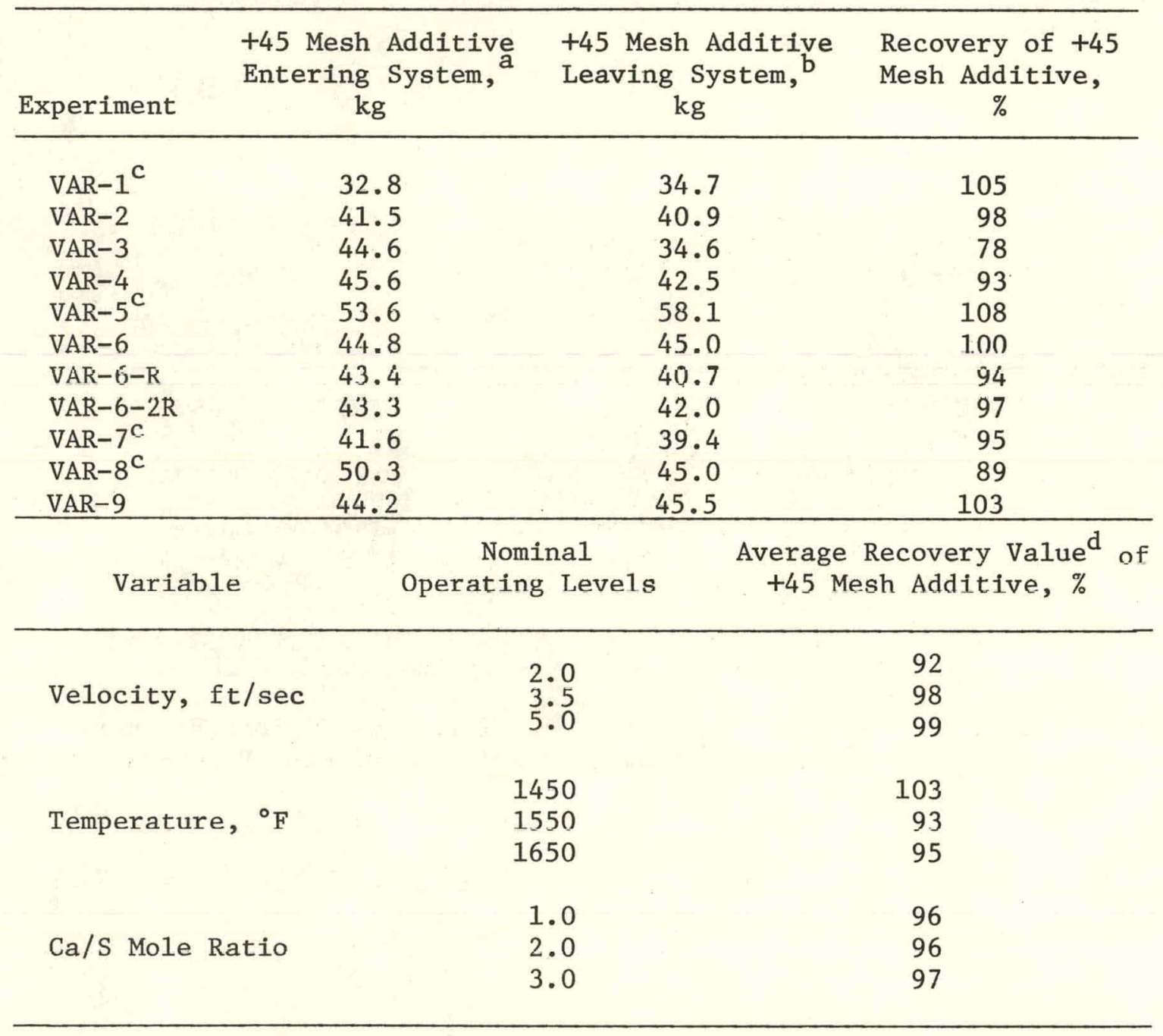

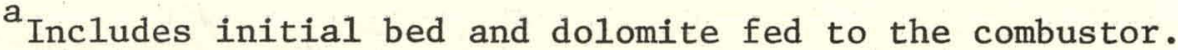

${ }^{b}$ Includes final bed, overflow, primary cyclone, and secondary cyclone products.

${ }^{c}$ Required an estimate of the size distribution of the initial bed based on the previous history of the additive material.

dAverage recovery for all "VAR" experiments $=96 \%$. 


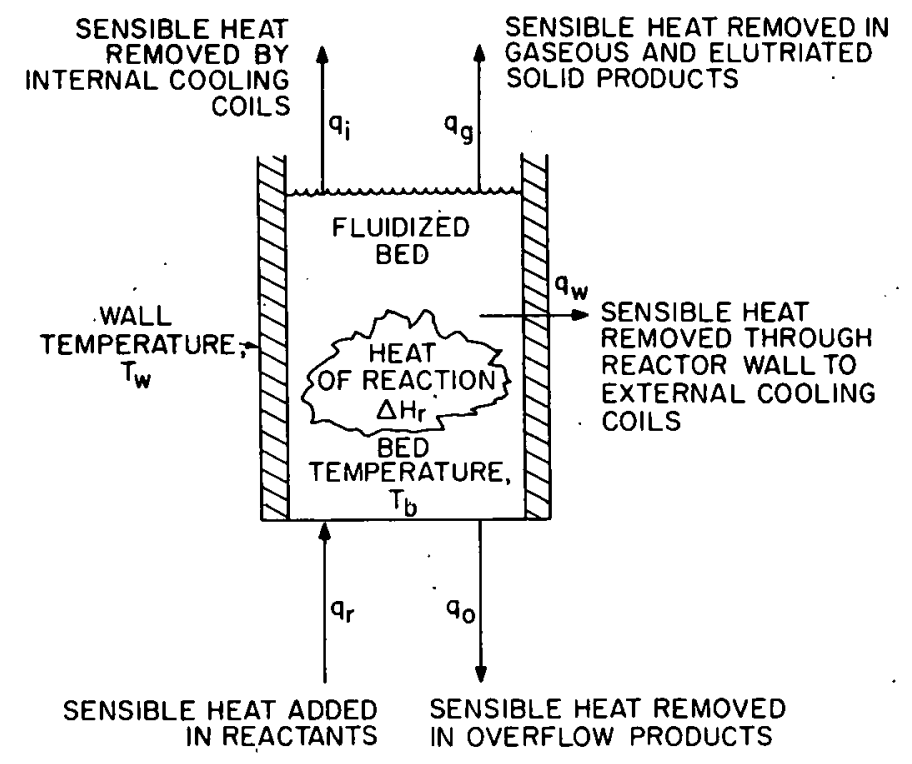

Figure 12. Factors Considered in the Calculation of Heat-Transfer Coefficients at the Combustor Wall

Assumptions inherent in Eq. 4 include: (1) heat transfer by radiation from the surface of the bed to metal surfaces above the level of the bed is negligible; (2) heat losses by conduction through the gas distributor supporting the fluidized bed and by conduction in the axlal direction in the reactor walls are negligible; (3) combustion products (gaseous and solid) leave the fluidized bed at the bed temperature; and (4) the internal cooling coils remove heat only from the fluidized bed ( $i . e .$, not from the gas above the bed). The first two assumptions tend to bias $\mathrm{q}_{\mathrm{w}}$ toward higher than actual values, whereas the last two assumptions tend to bias $q_{w}$ toward lower than actual values. Thus the omitted terms in Eq. 4, all estimated to be relatively minor compared to the amount of heat transferred between the fluidized bed and the vessel wall, tend to balance out the possibility of a large net cumulative bias of $\mathrm{q}_{\mathrm{w}}$ in either direction.

After obtaining a value for the heat transferred through the reactor wall, $\mathrm{q}_{\mathrm{w}}$, by $\mathrm{Eq}$. 4, the bed-to-wall heat-transfer coefficient, $\mathrm{U}_{i}$, was calculated by means of the equation

$$
\mathrm{U}_{i}=\mathrm{q}_{\mathrm{w}} \mathrm{A}_{\mathrm{i}} \Delta \mathrm{T}
$$


where $A_{i}$ is the inside surface area of the combustor wall between the distributor surface and the top of the standpipe regulating the height of the fluidized bed, and $\Delta T$ is the temperature difference between the bed temperature, $T_{b}$, and the inside wall surface temperature, $T_{i}$.

As $T_{i}$ was not measured directly, it was determined by an iterative solution of the following equations

$$
\begin{gathered}
T_{i}=T_{w}-\left[\frac{\left(q_{w}\right)\left(x_{w}\right)}{\left(k_{T_{m}}\right)\left(\bar{A}_{L}\right)}\right] \\
k_{T_{\text {III }}}=k_{0}+\frac{c\left(T_{w}+T_{i}\right)}{2}
\end{gathered}
$$

where $\mathrm{k}_{\mathrm{T}}$ equals the thermal conductivity of the reactor wall at the average $\mathrm{m}_{\mathrm{w}} 1 \mathrm{l}$ temperature, $\overline{\mathrm{A}}_{\mathrm{L}}$ is the $\log$ mean wall area for heat transfer, $X_{w}$ represents the wall thickness, $T_{w}$ is the experimentally determined outside wall temperature, and $k_{0}$ and $C$ are constants.

The values of bed-to-wall heat-transfer coefficients determined for the eleven experiments in the "VAR", series are presented in Table 10 and Fig. 13 as a function of velocity. Values of the coefficients range from about $40 \mathrm{BTU} /(\mathrm{hr})\left(\mathrm{ft} \mathrm{t}^{2}\right)\left({ }^{\circ} \mathrm{F}\right)$ at a gas velocity of about $2 \mathrm{ft} / \mathrm{sec}$ to more than $135 \mathrm{BTU} /(\mathrm{hr})\left(\mathrm{ft}^{2}\right)\left({ }^{\circ} \mathrm{F}\right)$ at $5 \mathrm{ft} / \mathrm{sec}$. The high degree of scatter that the data exhibit may be attributable to large uncertainties regarding (1) the effective height of the fluidized bed, because this determines the wall surface area actually being affected by the fluidized bed for heat transfer, and (2) the particle density of the fluidized bed, because this directly affects both the rate of heat transferred by conduction and convection through the lamina or sublayer of gas at the combustor wall. Bed temperature may also be a significant factor affecting the rate of radiant heat transfer between the bed and vessel wall. The effect of temperature is not obvious, however, from the data shown in Fig. 13.

The values reported here for bed-to-wall coefficients appear to be slightly higher than the 50 to $100 \mathrm{BIU} /(\mathrm{hr})\left(\mathrm{ft}^{2}\right)\left({ }^{\circ} \mathrm{F}\right)$ values reported for other fluidized-bed combustion systems as heat-transfer coefficients between the bed and tube surfaces immersed in the bed. 7

Solids Loading in the Flue Gas. Data on the distribution of flue-gas particulates in the "VAR" series of experiments are presented in Tables 11 and 12. The flue-gas particulate concentration is expressed as grains/scf in Table 11 , because these units are gcncrally uscd in detcrmining the suitability of the prcssurizcd fluc gas for driving a gas turbine. In Table 12, the distribution of fluegas particulates is expressed as $1 \mathrm{~b} / 10^{6}$ BTU. The latter units are 
Table 10. Heat-Transfer Coefficients for the "VAR" Series of Statistically Designed Combustion Experiments

\begin{tabular}{lcc}
\hline Experiments & $\begin{array}{c}\text { Fluidizing-Gas } \\
\text { Velocity, ft/sec }\end{array}$ & $\begin{array}{c}\text { Bed-to-Wall Heat-Transfer } \\
\text { Coefficient }\end{array}$ \\
\hline VAR-1 & 2.1 & 65 \\
VAR-3 & 2.1 & 42 \\
VAR-4 & 2.3 & 78 \\
VAR-5 & 3.4 & 65 \\
VAR-6 & 3.5 & 84 \\
VAR-6-2R & 3.5 & 101 \\
VAR-6-R & 3.6 & 96 \\
VAR-8 & 3.6 & 115 \\
VAR-7 & 4.2 & 100 \\
VAR-9 & 4.9 & 96 \\
VAR-2 & 4.8 & 136 \\
\hline
\end{tabular}

${ }^{a}$ Based on inside area of combustor wall.

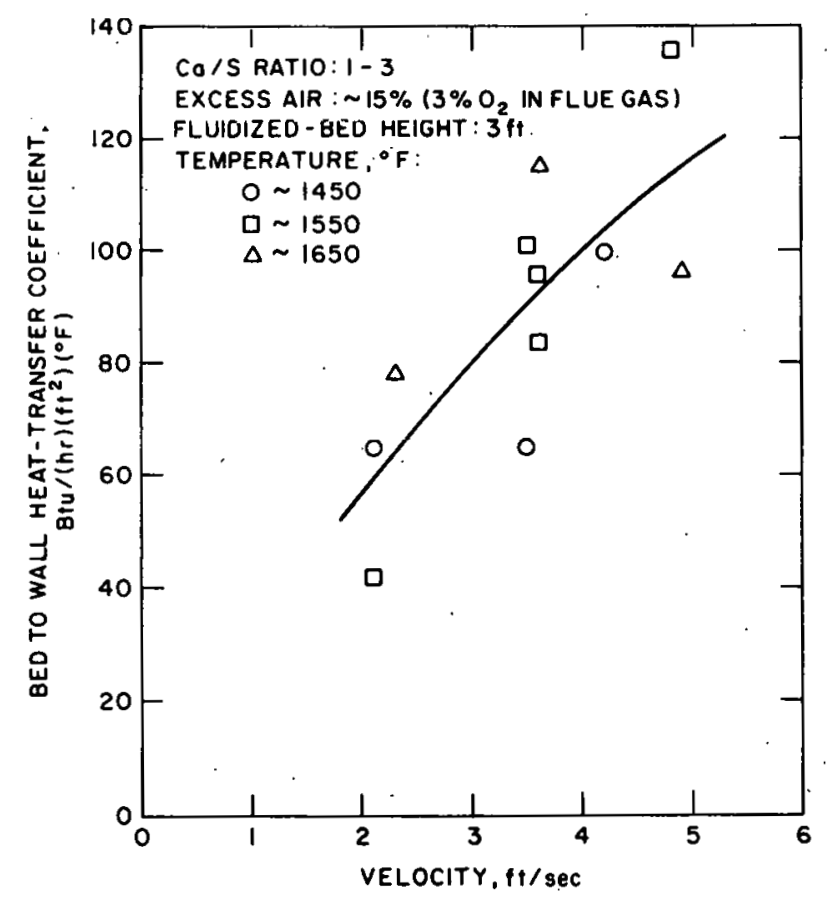

Figure 13. The Effect of Velocity on Calculated Bed-to-Wall Heat-Transfer Coefficients 
Table 11. Distribution cf Flue-Gas Particulates in "VAR"-Series Experiments Expressec in Units of Grains/scf

\begin{tabular}{|c|c|c|c|c|c|c|}
\hline \multirow[b]{2}{*}{ Experiment } & \multicolumn{2}{|c|}{ Noninal } & \multicolumn{2}{|c|}{ Flue-Gas Particulate } & \multicolumn{2}{|c|}{ Concentration, grains/scf } \\
\hline & $\begin{array}{c}\mathrm{Ca} / \mathrm{S}, \\
\text { Mole Ratio }\end{array}$ & $\begin{array}{c}B \in d \text { Temp, } \\
{ }^{\circ} \mathrm{F}\end{array}$ & $\begin{array}{c}\text { After } \\
\text { Combustor }\end{array}$ & $\begin{array}{c}\text { After 1st } \\
\text { Cyclone }\end{array}$ & $\begin{array}{l}\text { After 2nd } \\
\text { Cyclone }\end{array}$ & $\begin{array}{l}\text { After } \\
\text { Filter }\end{array}$ \\
\hline Gas velocity, $2.0 \mathrm{ft} / \mathrm{sec}$ & & & & & & \\
\hline $\begin{array}{l}\text { VAR-3 } \\
\text { VAR-4 } \\
\text { VAR-1 }\end{array}$ & $\begin{array}{l}1.0 \\
2.0 \\
3.0\end{array}$ & $\begin{array}{l}1550 \\
1650 \\
1450\end{array}$ & $\begin{array}{l}4.1 \\
4.8 \\
6.3\end{array}$ & $\begin{array}{l}0.7 \\
0.5 \\
0.8\end{array}$ & $\begin{array}{l}0.3 \\
0.3 \\
0.3\end{array}$ & $\begin{array}{l}b \\
b \\
b\end{array}$ \\
\hline Gas velocity, $3.5 \mathrm{ft} / \mathrm{sec}$ & & & & & & \\
\hline $\begin{array}{l}\text { VAR-5 } \\
\text { VAR-6 } \\
\text { VAR-6-R } \\
\text { VAR-6-2R } \\
\text { VAR-8 }\end{array}$ & $\begin{array}{l}1.0 \\
2.0 \\
2.0 \\
2.0 \\
3.0\end{array}$ & $\begin{array}{l}1450 \\
1550 \\
1550 \\
1550 \\
1650\end{array}$ & $\begin{array}{r}7.5 \\
8.3 \\
10.8 \\
10.0 \\
13.5\end{array}$ & $\begin{array}{l}1.3 \\
0.6 \\
0.5 \\
0.8 \\
0.9\end{array}$ & $\begin{array}{l}0.5 \\
0.2 \\
0.3 \\
0.4 \\
0.3\end{array}$ & $\begin{array}{l}b \\
b \\
b \\
b \\
b\end{array}$ \\
\hline Gas velocity, $5.0 \mathrm{ft} / \mathrm{sec}$ & . & & & & & \\
\hline $\begin{array}{l}\text { VAR-9 } \\
\text { VAR-7 } \\
\text { VAR-2 }\end{array}$ & $\begin{array}{l}1.0 \\
2.0 \\
3.0\end{array}$ & $\begin{array}{l}1650 \\
1450 \\
1550\end{array}$ & $\begin{array}{l}10.4 \\
17.8 \\
23.4\end{array}$ & $\begin{array}{l}0.5 \\
4.7 \\
1.2\end{array}$ & $\begin{array}{r}<0.3 \\
2.1 \\
0.7\end{array}$ & $\begin{array}{c}<0.1 \\
<0.1 \\
b\end{array}$ \\
\hline
\end{tabular}

\footnotetext{
astimated accuracy, $\pm 10 \%$.

bo data obtained.
} 
Table 12. Distribution of Flue-Gas Particulates in "VAR"--Series Experiments Expressed in Units of $1 \mathrm{~b} / 10^{6} \mathrm{BTU}$

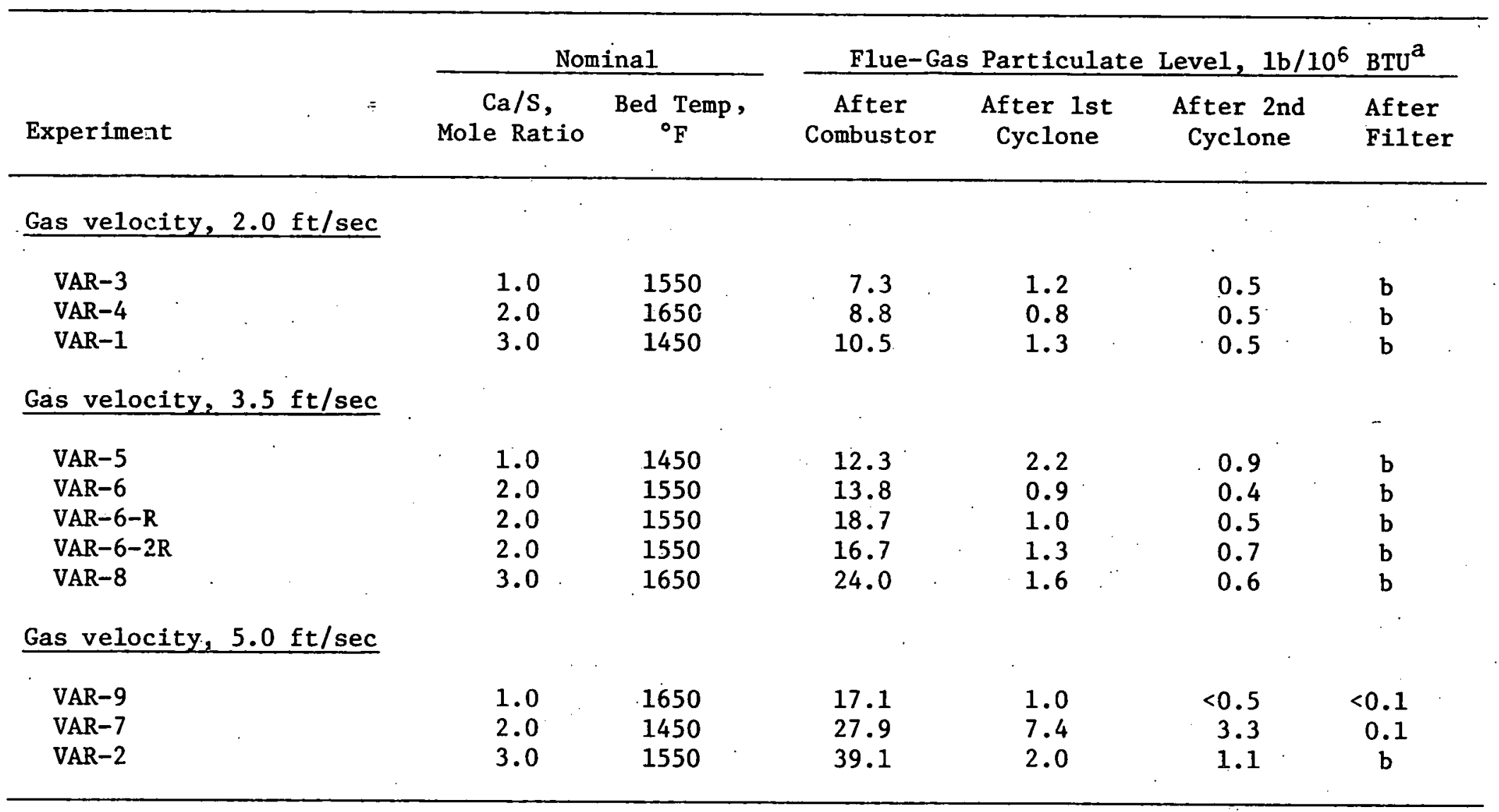

\footnotetext{
${ }^{a}$ Estimated accuracy, $+10 \%$.

$b_{\text {No data obtained. }}$
} 
used by EPA for control of particulate emission from a fossil-fuelfired steam-generating plant. Such a plant has a maximum particulate emission standard of $0.1 \mathrm{~b} / 10^{6}$. BTU heat input.

The solids loading in the flue gas as it left the combustor is graphically presented in Fig. 14 as a function of $\mathrm{Ca} / \mathrm{S}$ mole ratio at the three levels of gas velocity studied. Loadings ranged from a low of 4.1 grains/ft $\mathrm{ft}^{3}$ at a $\mathrm{Ca} / \mathrm{S}$ ratio of one and velocity of $2 \mathrm{ft} / \mathrm{sec}$ to a high of 23 grains $/ \mathrm{ft}^{3}$ at a Ca/s ratio of three and velocity of $5 \mathrm{ft} / \mathrm{sec}$. Extrapolation of the curves to zero $\mathrm{Ca} / \mathrm{S}$ ratio would roughly indicate the contribution to each curve made by the fly ash from the coal. At gas velocities of $2,3.5,5 \mathrm{ft} / \mathrm{sec}$, increasing the $\mathrm{Ca} / \mathrm{S}$ mole ratio from one to three increased the solids loading in the flue gas by 60,80 , and $125 \%$, respectively. While these results suggest the desirability of maintaining Low $\mathrm{Ca} / \mathrm{s}$ ratios to minimize solids loading from the additive, loadings at high $\mathrm{Ca} / \mathrm{S}$ ratios could be reduced significantly at suitably selected gas velocities and sorbent particle sizes. Thus, the loadings quoted here should not be considered representative of what could be acheived under optimized conditions.

The data presented in Tables 11 and 12 on the concentration of flue-gas particulates after the two cyclones and the filters are for informational purposes only and should not be construed as representing the limit of particulate retention. Design of the cyclones and filters used in the ANL combustion pilot plant was not optimized for particulate collection.

Carbon, Sulfur, and Calcium Material Balances. Carbon, sulfur, and calcium material balances have been calculated for the "VAR" experiments. The calculations were based on chemical analyses of riffled samples of the various solids streams added to, or removed from, the combustor and on analyses of the flue gas for $\mathrm{CO}_{2}, \mathrm{CO}, \mathrm{CH}_{4}$, and $\mathrm{SO}_{2}$. The results are summarized in Table 13. More detailed material-balance data for each of the eleven experiments in the "VAR" series are presented in Appendix B of this report, Tables B-1 through $\mathrm{B}-11$, inclusive.

As shown in Table 13, the material balances ranged from 103 to $116 \%$ for carbon, from 80 to $99 \%$ for sulfur, and from 79 to $107 \%$ for calcium. In light of the numerous possibilities for inaccuracies in weighing, sampling, and analysis of the various streams, material balances of $100+10 \%$ are considered acceptable. Of the 33 values shown in Table $1 \overline{3}, 25$ (or $76 \%$ ) of the values are within this range.

Particle-Size Distribution of Fluidized-Bed and Elutriated Solids. Screen analysis data for the "VAR" experiments are presented in Table C-1 of Appendix $C$ and summarized in Fig. 15, which is a pilot of the mass-mean particle diameters of the indicated samples against gas velocity. The data reflect the increased elutriation of additive with increased velocity as shown in Fig. 10. As the gas velocity increases, progressively larger bed particles are elutrlated from the bed and retained in the cyclones. Thus, the mean diameters of all the samples tend to increase with increasing gas velocity. 


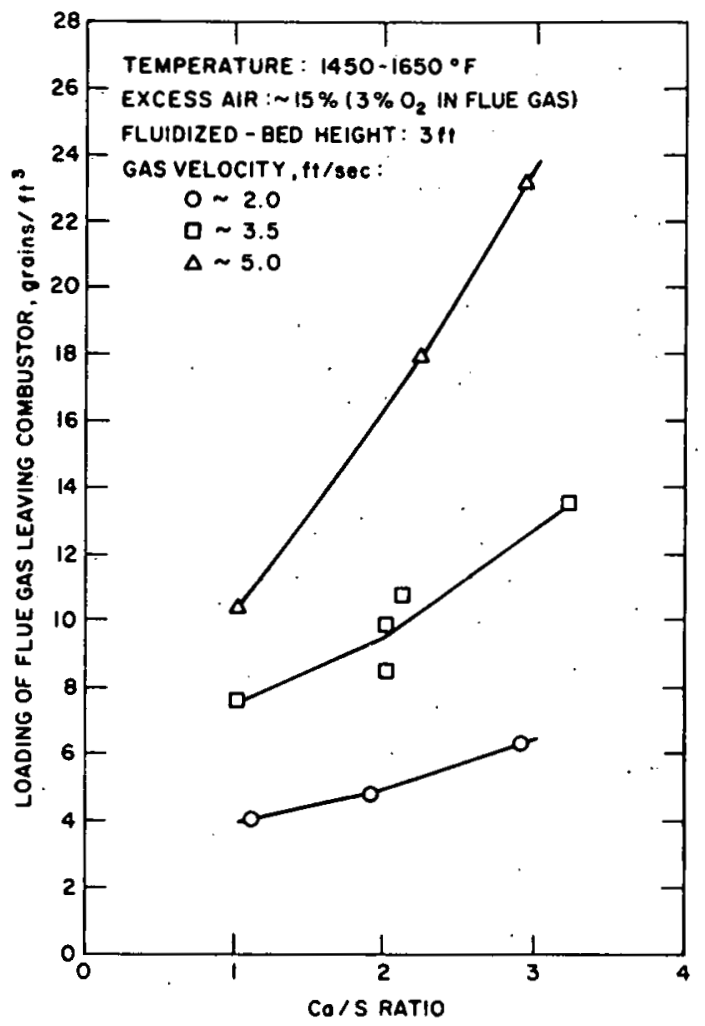

Figure 14. Solids Loading of Flue Gas Leaving the Combustor as a Function of $\mathrm{Ca} / \mathrm{S}$ Mole Ratio and Gas Velocity

Table 13. Carbon, Sulfur, and Calcium Material Balances for "VAR" Series of Experiments

\begin{tabular}{cccc}
\hline & \multicolumn{3}{c}{ Percent Accounted } \\
\cline { 2 - 4 } Experiment & Carbon $^{\mathrm{a}}$ & Sulfur $^{\mathrm{b}}$ & Calcium $^{\mathrm{c}}$ \\
\hline VAR-1 & 116 & 80 & 106 \\
VAR-2 & 114 & 96 & 107 \\
VAR-3 & 103 & 88 & 86 \\
VAR-4 & 113 & 93 & 92 \\
VAR-5 & 107 & 93 & 79 \\
VAR-6 & 105 & 90 & 92 \\
VAR-6-R & 105 & 90 & 97 \\
VAR-6-2R & 105 & 90 & 93 \\
VAR-7 & 104 & 99 & 96 \\
VAR-8 & 116 & 95 & 97 \\
VAR-9 & 108 & 95 & 93 \\
\hline
\end{tabular}

analytical accuracy, $\pm 5 \%$ relative for solid samples.

$\mathrm{b}_{\text {For }}>5 \%$ sulfur, analytical accuracy, $\pm 5 \%$ relative for solid samples. For $<5 \%$ sulfur, analytical accuracy, $\pm 10 \%$ relative for solid samples.

c Analytical accuracy, $\pm 2 \%$ relative. 


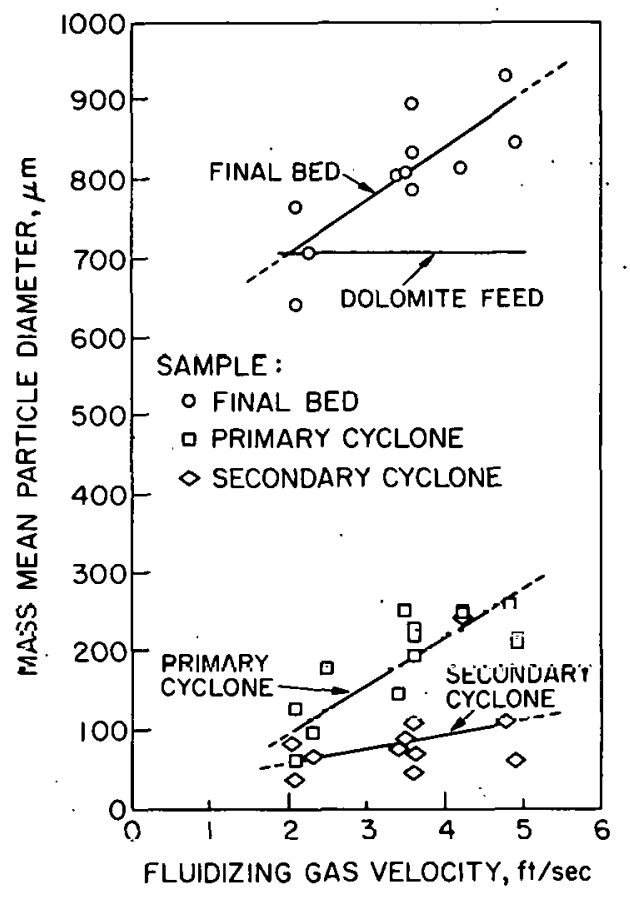

Figure 15. Mean Particle Diameters of Solld Samples from the "VAR" Series of Combustion Experiments vs. Fluidizing-Gas Velocity

The results of limited experience gained in the use of a Brink impactor to measure the solids loading and particle-size distribution in the flue gas being vented from the system are presented in Appendix $D$.

Combuetion-Side Corrosion of Internal Cooling Coils. Corrosion on the external (or bed) side of an internal cooling coil was studied after an estimated $500 \mathrm{hr}$ of operating time. Samples No. 3 and 11, taken from the cooling coil where it extended below the surface of the fluidized bed, exhibited intergranular corrosion to a depth of $\sim 30 \mu \mathrm{m}$ (see Fig. 16). Both samples exhibited sensitization and sigma phase formation. Sensi-. tization of type 310 SS occurs at 800 to $1500^{\circ} \mathrm{F}$ and sigma phase formation at $1200^{\circ} \mathrm{F}$. It should be noted that tube temperatures were not carefully controlled and may have occasionally approached the temperature of the fluidized bed. In a commercial unit with optimized tube materials and carefully controlled metal temperatures, it should be possible to keep corrosion within acceptable limits.

Sample No. 12, shown in Fig. 17, was taken from the cooling coil in the freeboard area of the combustor, $\sim 41 / 2 \mathrm{ft}$ above the bed. Very little internal, or coolant-side, corrosion was observed, but external, or bed-side, corrosion was to a depth of $600 \mu \mathrm{m}$. The sample was examined using an electron microprobe. Photographic images show some depletion of $\mathrm{Fe}$ and $\mathrm{Ni}$ along the grain boundaries where corrosion took place. Sulfur is seen in these grain boundaries to the depth of corrosion. Electrolytic etching of the sample showed that the metal was sensitized. This particular sample had seen $21000 \mathrm{hr}$ of operating time. 


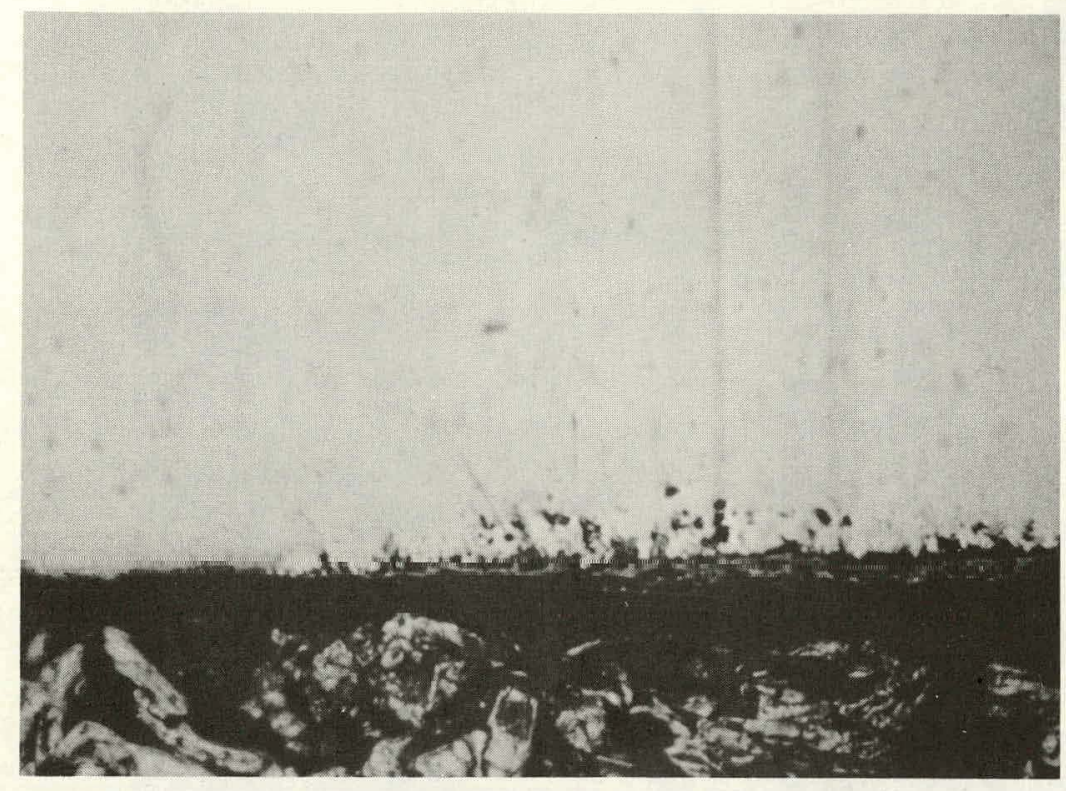

a. As-polished Photomicrograph of Sample No. 3 (275X)

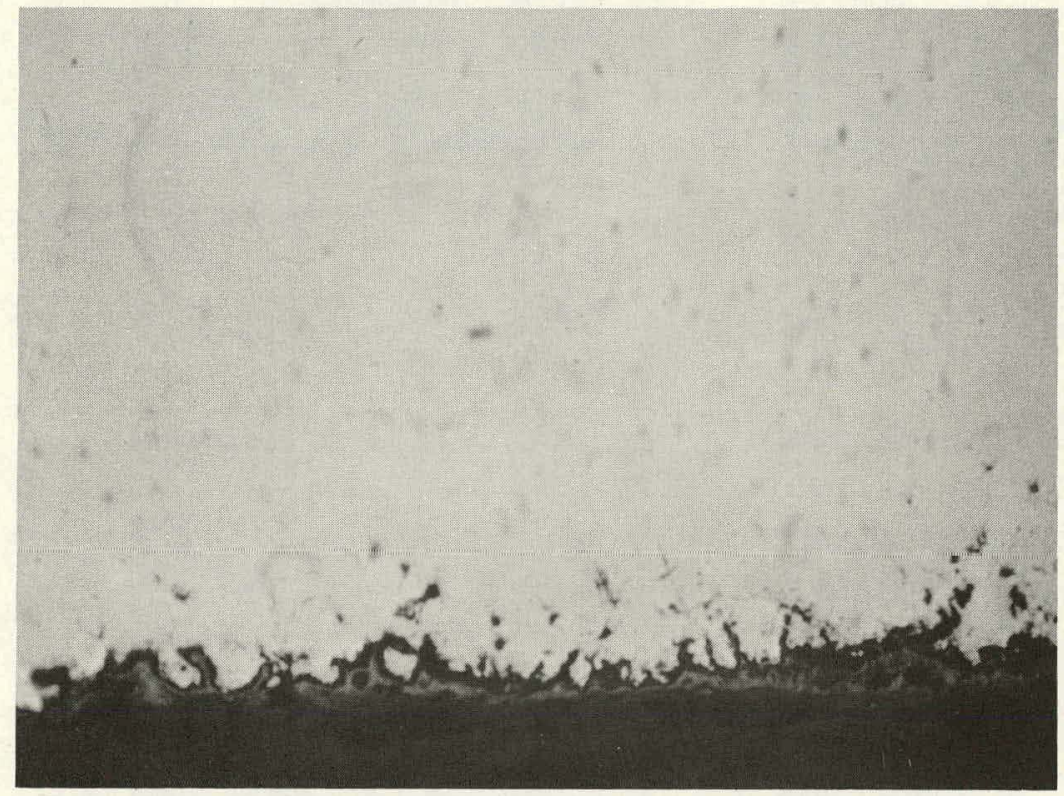

b. As-polished Photomicrograph of Sample No. 11 (275X)

Figure 16. Sample No. 3 and 11, Showing IntergranularType Corrosion on the Bed-Side Wall of an Internal Cooling Coil Immersed in the Fluidized Bed 


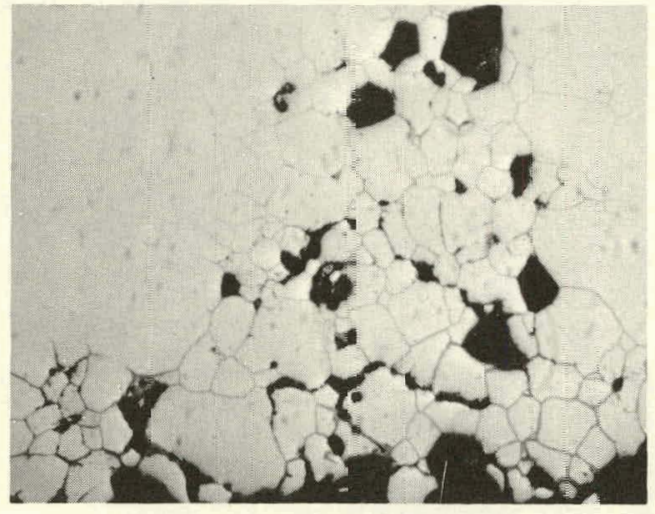

a. As-polished Photomicrograph of Sample No. 12 (116X)

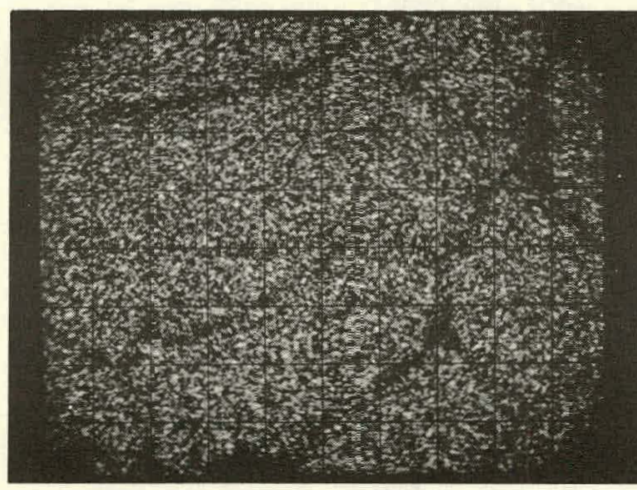

d. Nicke] Phase

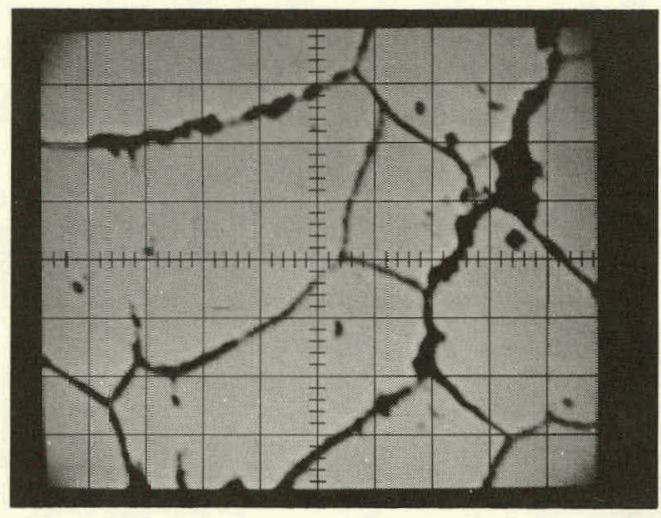

b. Specimen Current

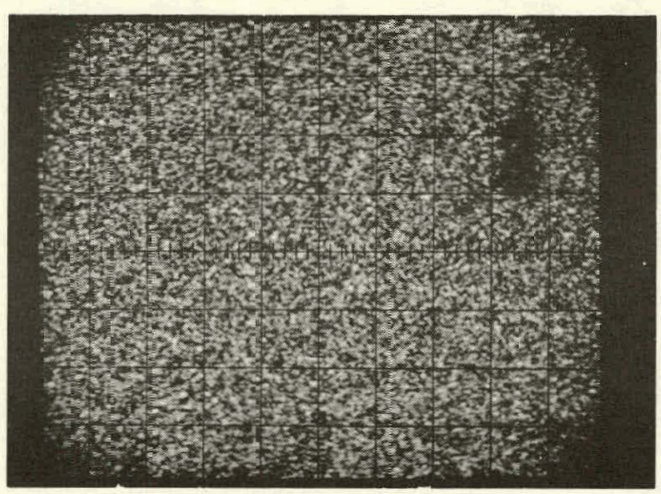

e. Chromium Phase

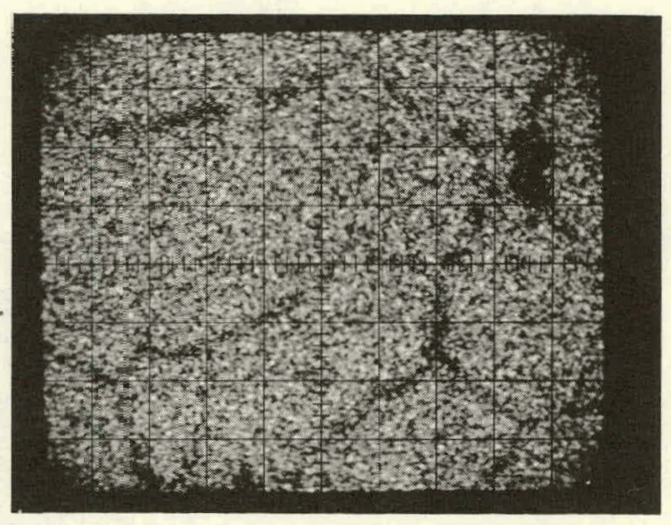

c. Iron Phase

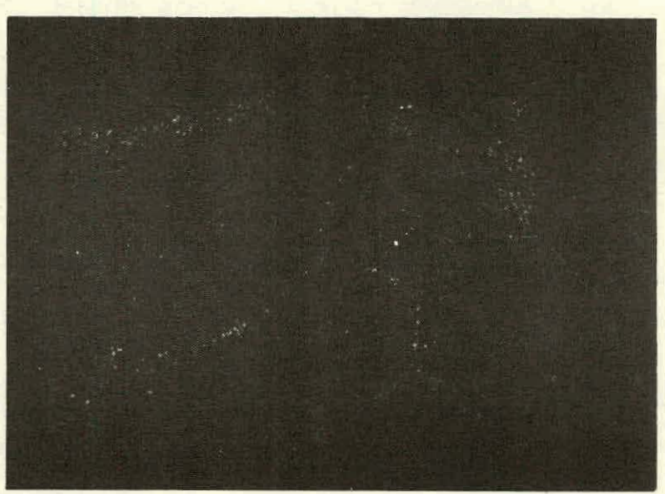

f. Sulfur Phase

Figure 17. Photomicrograph and Electron Nicroprobe Scanning Images of Intergranular-Type Corrosion Found in Process-Gas Side of Sample Removed from an Internal Cooling Coil in the Freeboard Area (A11 Images $40 \times 50 \mu \mathrm{m}$ ) 
Combustion of Low-Sulfur, Subbituminous and Lignite Coals

Combustion experiments were made in the 6-in.-dia pressurized combustor to determine whether any difficulties would be encountered in processing a San Juan mine, subbituminous coal having a high coalash content of $17 \%$ and a Glenharold mine lignite having a low heating value of $7,625 \mathrm{BTU} / \mathrm{lb}$. The nominal operating conditions for the two experiments were a bed temperature of $1550^{\circ} \mathrm{F}$, fluidizing-gas velocity of $3.5 \mathrm{ft} / \mathrm{sec}$, and an $\mathrm{O}_{2}$ concentration of $3 \%$ in the dry flue gas. Due to the low sulfur content $(<1$ wt $\%$ ) of the two coals, a Ca/s mole ratio of 1.0 was selected. In Table 14 are summarized the actual operating conditions and flue-gas analyses for the two experiments. Included in this table are estimated $\mathrm{SO}_{2}$ and NO flue-gas compositions for Arkwright coal combusted under nominally similar operating conditions. The estimates are based on correlations reported for the results of combustion experiments with Arkwright coal.

Operating Performance. The operating performance of the fluidizedbed combustor during the combustion of both the subbituminous and lignite coals was excellent. These results, coupled with the performance of the combustor in processing the highly-caking, high-volatilebituminous Arkwright coal, successfully demonstrate the versatility of the fluidized-bed concept for processing coals of widely varying rank and quality.

Sulfur Dioxide Retention. The $\mathrm{SO}_{2}$ levels of 250 and $120 \mathrm{ppm}$ for the combustion of the subbituminous and lignite coals, respectively, correspond to emissions of 0.45 and $0.211 \mathrm{~b} \mathrm{SO} \mathrm{SO}_{2} / 10^{6} \mathrm{BTU}$. By way of comparison, combustion of the Arkwright bituminous coal under similar conditions would have a projected $\mathrm{SO}_{2}$ emission of $610 \mathrm{ppm}$ or $1.15 \mathrm{lb}$ $\mathrm{SO}_{2} / 10^{6}$ BTU. Correspondingly, the above $\mathrm{SO}_{2}$ emissions represent sulfur retentions of approximately 72,72 , and $85 \%$ for the bituminous, subbituminous, and lignite coals, respectively.

The somewhat higher retention reported for the combustion experiment with lignite may be a result of the relatively high calcium content of the coal itself. Data in Table 15 show that $\mathrm{Ca} / \mathrm{S}$ ratios calculated just on the basis of calcium and sulfur contents for the respective coals range from as low as 0.08 for the bituminous coal up to 0.96 and 1.94 for the subbituminous and lignite coals, respectively. Including the coal calcium with the calcium in the additive results in potentially effective Ca/S ratios of $1.1,2.1$, and 3.0 for the three combustion experiments as indicated in Table 15.

The potential effect of the coal calcium on sulfur retention during combustion is indicated by the percentage of the sulfur in the coal which was reportedly retained by the coal during ashing for mineral analyses. For the bituminous coal, where the coal $\mathrm{Ca} / \mathrm{S}$ ratio is only 0.08 , the amount of sulfur retained during ashing was only $3.7 \%$. Sulfur retentions during ashing for the subbituminous and lignite coals, however, increased to as high as 42 and $99 \%$, respectively. 
Table -4: Actua: Operating Conditions and Flue-Gas Analysis for Combustion Experiments with Low-Sulfur Subbituminous and Lignite Coals

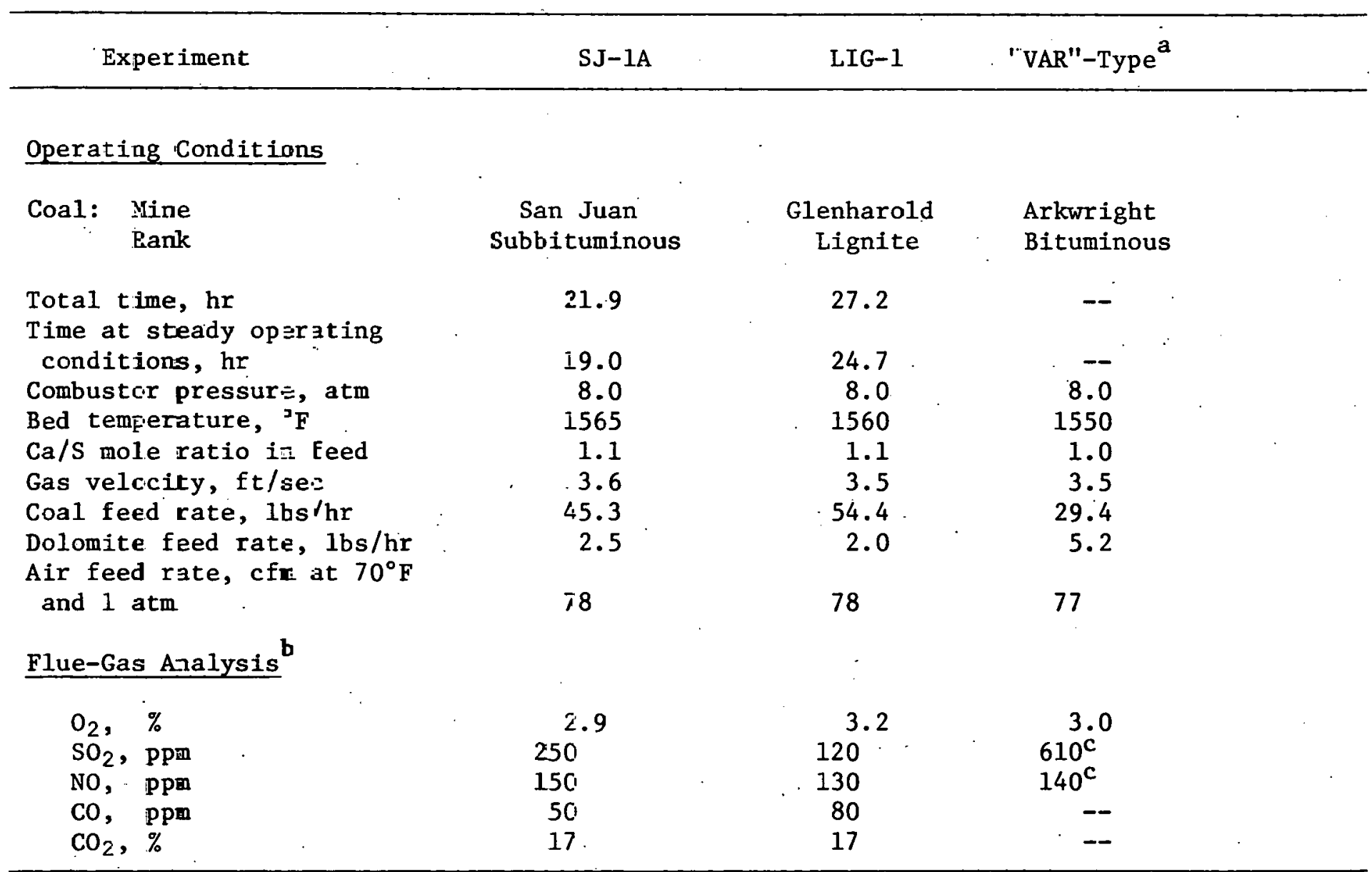

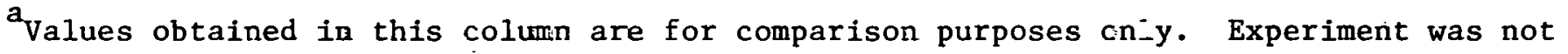
made at =hese conditions.

bry basis.

CPredicted values based on correlations derived from data of "PAR"-series experiments. 
Table 15. Potential Effect of the Calcium Content of Coals Tested on the Retention of Sulfur during Fluidized-Bed Combustion

\begin{tabular}{|c|c|c|c|}
\hline Experiment & "VAR"-Type & $\mathrm{SJ}-1 \mathrm{~A}$ & LIG-1 \\
\hline $\begin{array}{ll}\text { Coal: } & \text { Mine } \\
& \text { Rank }\end{array}$ & $\begin{array}{l}\text { Arkwright } \\
\text { Bituminous }\end{array}$ & $\begin{array}{l}\text { San-Juan } \\
\text { Subbituminous }\end{array}$ & $\begin{array}{l}\text { Glenharold } \\
\text { Lignite }\end{array}$ \\
\hline $\begin{array}{l}\text { Coal sulfur content, wt } \% \\
\text { Coal calcium content, wt } \% \\
\text { Coal } \mathrm{Ca} / \mathrm{s} \text { ratio }\end{array}$ & $\begin{array}{l}2.82 \\
0.27 \\
0.08\end{array}$ & $\begin{array}{l}0.78 \\
0.75 \\
0.96\end{array}$ & $\begin{array}{l}0.53 \\
1.03 \\
1.94\end{array}$ \\
\hline $\begin{array}{l}\text { Percent sulfur retained by } \\
\text { coal during ashing for } \\
\text { mineral analysis }\end{array}$ & 3.7 & 42 & 99 \\
\hline $\begin{array}{l}\text { Ratio of calcium in additive } \\
\text { to sulfur in coal for } \\
\text { experiment }\end{array}$ & 1.0 & 1.1 & 1.1 \\
\hline $\begin{array}{l}\text { Total potentially ef jective } \\
\text { Ca's ratio }\end{array}$ & 1.1 & 2.1 & 3.0 \\
\hline Sulfur retention, $\%$ & $72^{b}$ & 72 & 85 \\
\hline
\end{tabular}

${ }^{a}$ Based on ultimate and mineral analyses performed by Commercial Testing Laboratories, Chicago, Illinois.

${ }^{b}$ Estimated from results of combustion experiments with Arkwright coal. 
A further indication of the activity of coal calcium in sulfur retention was observed during a combustion experiment in which Arkwright coal was combusted in a fluidized bed of Alundum. Flue-gas analyses for the particular experiment indicated a sulfur retention in the bed of approximately $3 \%$ as compared with $3.7 \%$ retained by the coal during ashing.

Nitrogen Oxide Emissions. The NO levels of $150 \mathrm{ppm}$ and $130 \mathrm{ppm}$, respectively, for the combustion experiments with the subbituminous and lignite coals correspond to emissions of 0.19 and $0.181 \mathrm{~b} \mathrm{NO} \mathrm{N}_{2} / 10^{6}$ BTU. The projected emission for the Arkwright coal (140 ppm) under similar conditions is $0.19 \mathrm{Ib} \mathrm{NO}_{2} / 10^{6} \mathrm{BTU}$.

Combustion Efficiencies. Combustion efficiencies for the two experiments were 94 and $97 \%$ for the San Juan and Glenharold coals, respectively. These values agree well with the combustion efficiency of $94 \%$ reported for the Arkwright coal at a combustion temperature of $1550^{\circ} \mathrm{F}$ (see Fig. 7).

Calcium Utilization. Calcium utilizations for the final bed material of 74 and $71 \%$ for the combustion experiments with the San Juan and Glenharold coals, respectively, in Tymochtee dolomite at a $\mathrm{Ca} / \mathrm{S}$ mole ratio of 1.0 , are in relatively good agreement with the 76 to $83 \%$ utilizations reported above for combustion experiments with Arkwright coal using the same dolomite and the same mole ratio. The slightly lower utilizations for the lower rank coals is undoubtedly a reflection of the high calcium content of the coals themselves. The relatively high calcium ashes of the. low rank coals, even at low ash concentrations in the final bed material, may give somewhat misleading and depressed additive utilizations (assuming coal $\mathrm{Ca}$ is not as fully utilized as additive $\mathrm{Ca}$ ).

Material Balances and Screen Allalysés. Overall carbon, sulfur; and calcium material balancès were calculated fui the cumbustion experiments with the low-sulfur coals. 'l'he material balances are presented in Tables $\mathrm{B}-12$ and $\mathrm{B}-13$ of Appendix B for experiments SJ-1A and L1G-1, respectively. Except for the 1ow Ca balance (75\% recovery) for experiment SJ-1A and the high sulfur balance (116\% recovery) for experiment $L 1 G-1$, the material balances are simllar to Lhuse repuitied for the "VAR"-series experiments.

Particle-size data for the starting bed, final bed, bed overflow, and elutriated solids collected in the primary cyclone for experiments SJ-1A and L1G-1 are shown in Table C-2 of Append1x C. No particlesize data were obtained for the elutriated solids collected in the secondary cyclone or the primary and secondary filters because the material collected in these units "balled" when screening was attempted. 
Effect of Combustor Pressure and Temperature on the Concentration of NO and Other Gases in the Flue Gas

The concentration of No in the flue gas is significantly lower in coal combustion experiments made at eight atmospheres pressure than at one atmosphere. In the "VAR" series of experiments at eight atmospheres pressure, No concentrations ranged from 120 to $270 \mathrm{ppm}$ (see Table 2). In atmospheric tests made with a variety of coals and conditions in the previously installed atmospheric-pressure combustor, the NO concentration was generally above $300 \mathrm{ppm}$ (see ANL/ES/CEN-1004). Two series of experiments were conducted for the specific purpose of studying the effect of combustor operating pressure on concentrations of NO and other gases in the flue gas. The NOX-I series involved the combustion of Arkwright coal in a fluidized bed of Alundum. In the NOX-II series, Arkwright coal was combusted in a fluidized bed of sulfated dolomite while feeding dolomite to the bed at a $\mathrm{Ca} / \mathrm{S}$ feed mole ratio of 1.5 . Nominal operating conditions in both series were a bed temperature of $1550^{\circ} \mathrm{F}, 3 \% \mathrm{O}_{2}$ in the off gas, and a fluidizinggas velocity of $3.5 \mathrm{ft} / \mathrm{sec}$. Each of the two series of experiments consisted of six parts with the combustor pressure ranging from 1 to 8 atm. In a third series of experiments, the system pressure was maintained at $4 \mathrm{~atm}$ ( $60 \mathrm{psia}$ ), and the bed temperature was changed from 1.450 to 1550 and to $1650^{\circ} \mathrm{F}$.

In addition to the concentrations of gases ordinarily monitored In the flue gas $\left(\mathrm{O}_{2}, \mathrm{CO}_{2}, \mathrm{SO}_{2}, \mathrm{CO}\right.$, NO, and $\left.\mathrm{CH}_{4}\right)$, instrumentation was installed for the continuous or intermittent determination of ammonia, hydrogen, and $\mathrm{C}_{2}-\mathrm{C}_{4}$ hydrocarbons. An EAI Quad 1200 residual gas analyzer (quadrupole mass analyzer) was used to determine the $\mathrm{NH}_{3}$ concentration in the flue-gas stream. The $\mathrm{H}_{2}$ and $\mathrm{C}_{2}-\mathrm{C}_{4}$ hydrocarbons were analyzed by gas chromatography. Hydrogen was also analyzed by a thermal conductivity detector. Ethylene, ethane, acetylene, propane, iso-propane, and butane were analyzed by a flame ionization detector.

An attempt was also made to monitor $\mathrm{NO}_{2}$ continuously using a Mast Model 724-11 analyzer, preceded by sodium carbonate scrubbers to remove potential $\mathrm{SO}_{2}$ interference. (Separate laboratory experiments indicated that a gas stream containing up to $2500 \mathrm{ppm} \mathrm{SO}_{2}$ can be scrubbed to less than 1 ppm using this procedure.) However, the Mast analyzer, which is actually designed for ambient air monitoring, gave results that appeared to be biased by other flue-gas components, such as strong oxidizing agents. The pressure and temperature effects of $\mathrm{NO}_{2}$ flue-gas levels will, therefore, be reserved for a future investigation.

The $\mathrm{NO}_{2}$ component has generally been considered to be a relatively minor flue-gas component ( $<50 \mathrm{ppm})$, although only limited data are available. Information that has been published was obtained by British workers, who, in combustion experiments made at 5 to $6 \mathrm{~atm}$, measured NO and $\mathrm{NO}_{2}$ levels on the order of $150 \mathrm{ppm}$ and 5 to $10 \mathrm{ppm}$, respectively. 
Pressure Effect on NO Levels in the Flue Gas. The NO data gathered from the NOX-I and NOX-II experiments are presented in Fig. 18, which illustrates the effect of pressure on the concentration of No in the flue gas. In the absence of dolomite (NOX-I series), a rapid increase in NO concentration is noted as the combustor pressure is reduced, going from less than $200 \mathrm{ppm}$ at $8 \mathrm{~atm}$ to around $1600 \mathrm{ppm}$ at $1 \mathrm{~atm}$. The levels of No reported for this experiment were higher than those previously observed during combustion of coal in Alundum beds. No explanation is available for this result.

In the presence of dolomite (NOX-II series), an increase in NO is also observed at reduced pressures, although it is considerably less pronounced than in the first series of experiments. The level of NO increased from $\sim 200 \mathrm{ppm}$ at $8 \mathrm{~atm}$ to $\sim 400 \mathrm{ppm}$ at 1 atm. The NO levels observed for this series are consistent with previously repurted values.

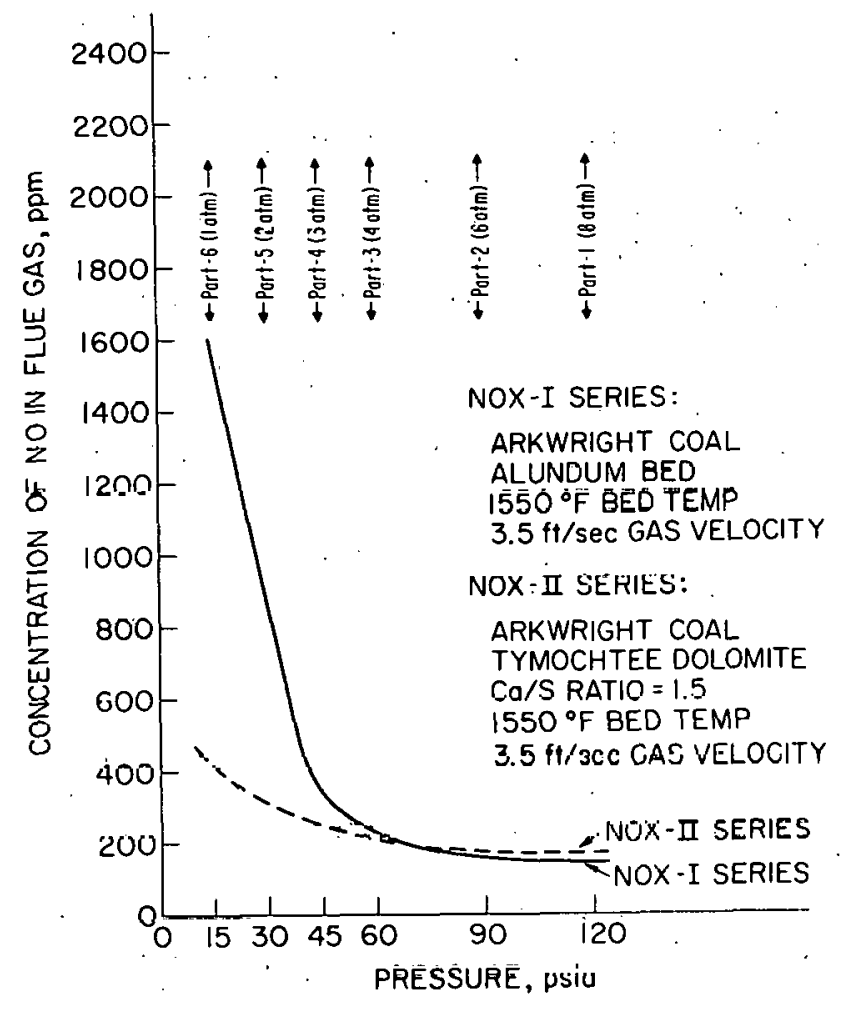

Figure 18. Effect of Pressure on Concentration of NO in Flue Gas 
Pressure Effect on the Concentration of Flue-Gas Components Other Than NO. The observed concentrations of $\mathrm{SO}_{2}, \mathrm{CO}, \mathrm{H}_{2}$, and $\mathrm{CH}_{4}$ in the flue gas of the NOX-I and NOX-II series of experiments are presented in Figs. 19 and 20, respectively. After an analysis of the data, the following conclusions were drawn:

1. The $\mathrm{SO}_{2}$ concentration is not affected greatly by changes in system pressure. During the NOX-I experiments, the $\mathrm{SO}_{2}$ level was essentially constant at $\sim 2300 \mathrm{ppm}$ between 1 and 8 atm of pressure. In the NOX-II experiments, the $\mathrm{SO}_{2}$ level ranged from 400 to $600 \mathrm{ppm}$ over the same pressure range.

2. Methane levels in the flue gas increase as the operating pressure is reduced below about $6 \mathrm{~atm}$. In both series of experiments, the $\mathrm{CH}_{4}$ level was a fairly constant $25 \mathrm{ppm}$ at 6 and $8 \mathrm{~atm}$. The level of $\mathrm{CH}_{4}$ then increased rapidly with decreasing pressure to around $400 \mathrm{ppm}$ at 1 atm.

3. In the presence of dolomite, Co levels in the flue gas increased from $170 \mathrm{ppm}$ at 8 atm to over $2000 \mathrm{ppm}$ at $1 \mathrm{~atm}$. In the absence of dolomite, the CO level passed through a minimum ( $100 \mathrm{ppm}$ ) at around 4 atm pressure, and increased rapidly with either increasing or decreasing pressures. This phenomenon remains unexplained.

4. The level of $\mathrm{H}_{2}$ is relatively unaffected by changes in pressure from $8 \mathrm{~atm}$ to $2 \mathrm{~atm}$, remaining at about $35 \mathrm{ppm}$ in both series of experiments. In the NOX-II experiments with dolomite, the level of $\mathrm{H}_{2}$ increased to $330 \mathrm{ppm}$ at $1 \mathrm{~atm}$.

5. The levels of the other gases were below the detection limits of the instrument used for their measurement. Ammonia was found to be $<100 \mathrm{ppm}$ for both series of experiments. The flue-gas ethylene, ethane, acetylene, propane, and iso-propane concentrations were $<10 \mathrm{ppm}$, and the butane, $<20 \mathrm{ppm}$.

Effect of Temperature on the Concentration of Flue-Gas Constituents. A series of three experiments was also completed to determine the effect of system temperature on concentrations of flue-gas constituents. The data from these experiments are presented in Fig. 21 . Under the conditions at which the experiments were performed, temperature variations from $1450^{\circ} \mathrm{F}$ to $1650^{\circ} \mathrm{F}$ had little or no effect on the composition of the flue-gas components investigated. 


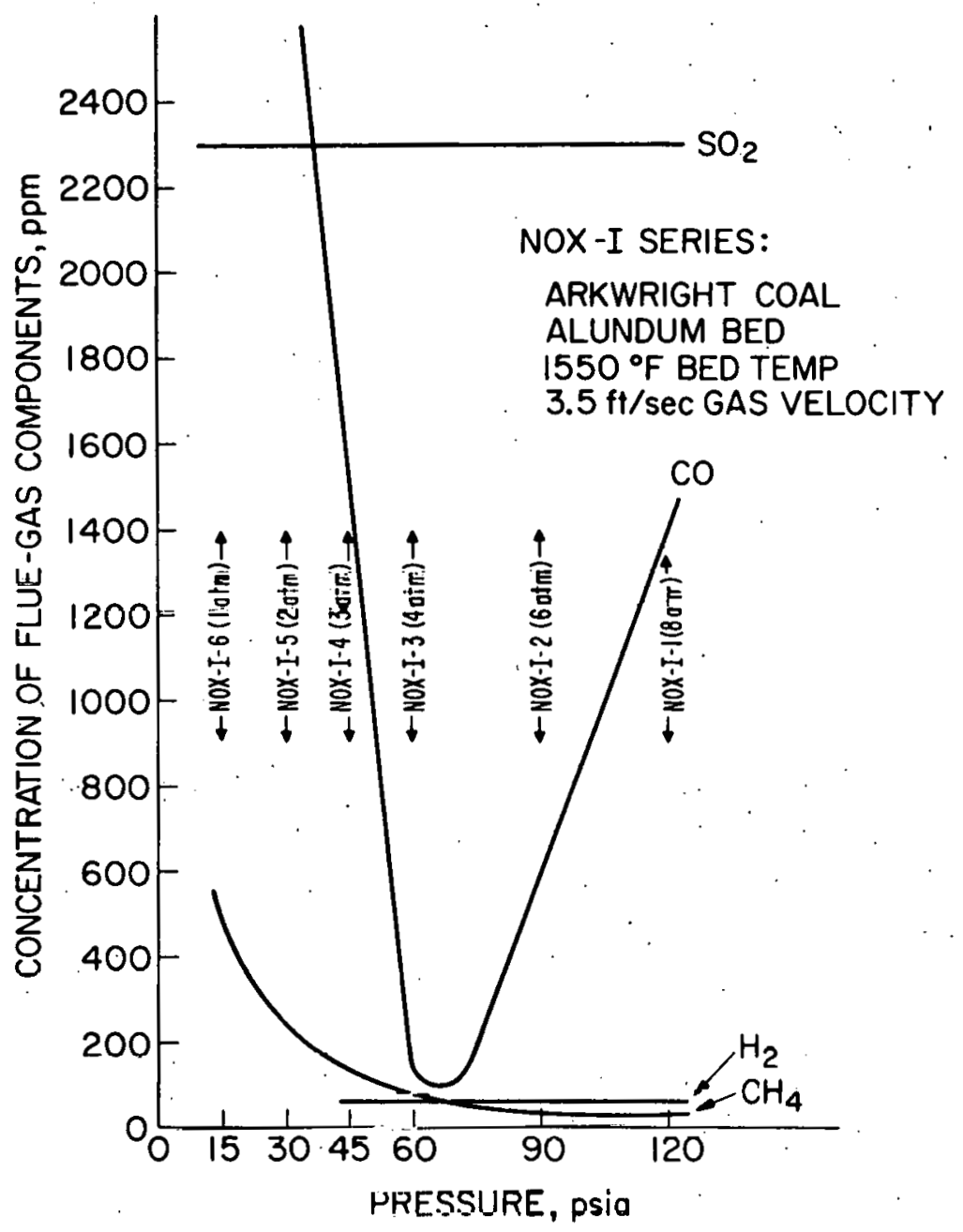

Figure 19. Effect of Pressure on Concentration of Flue-Gas Components Other Than NO for Series NOX-I 


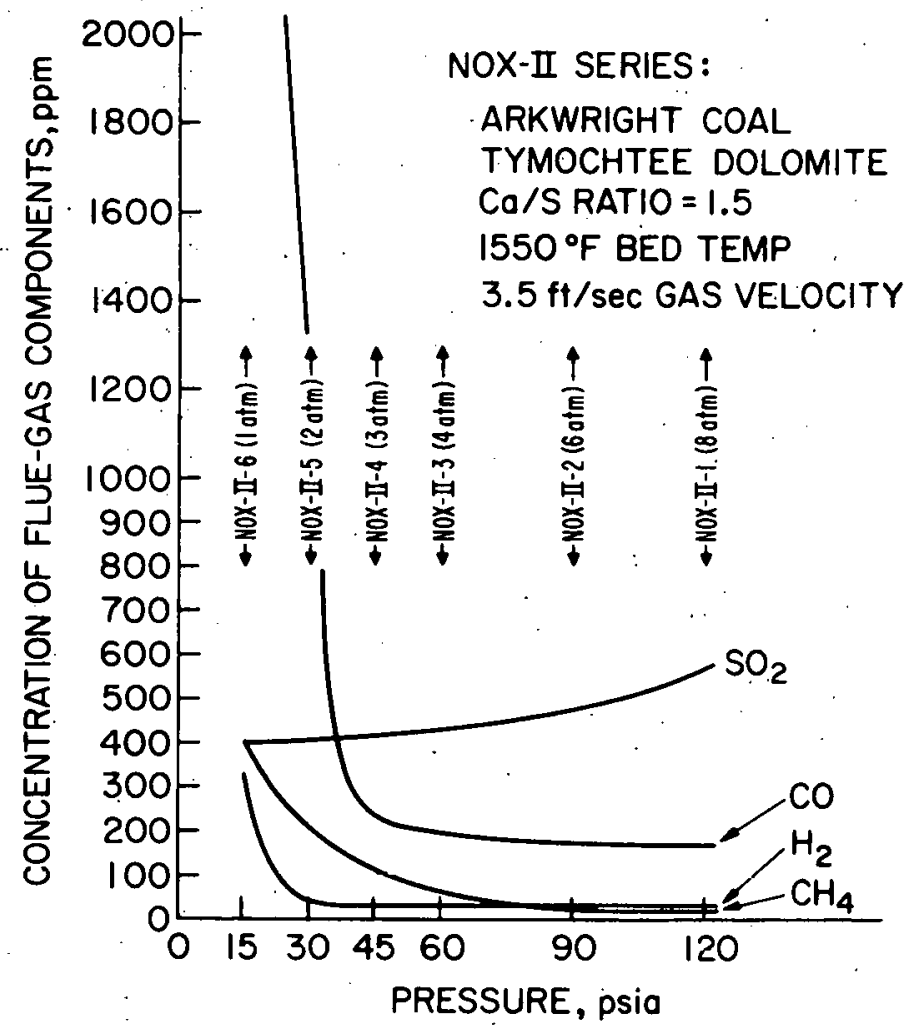

Figure 20. Effect of Pressure on Concentration of Flue-Gas Components Other Than NO for Series NOX-II

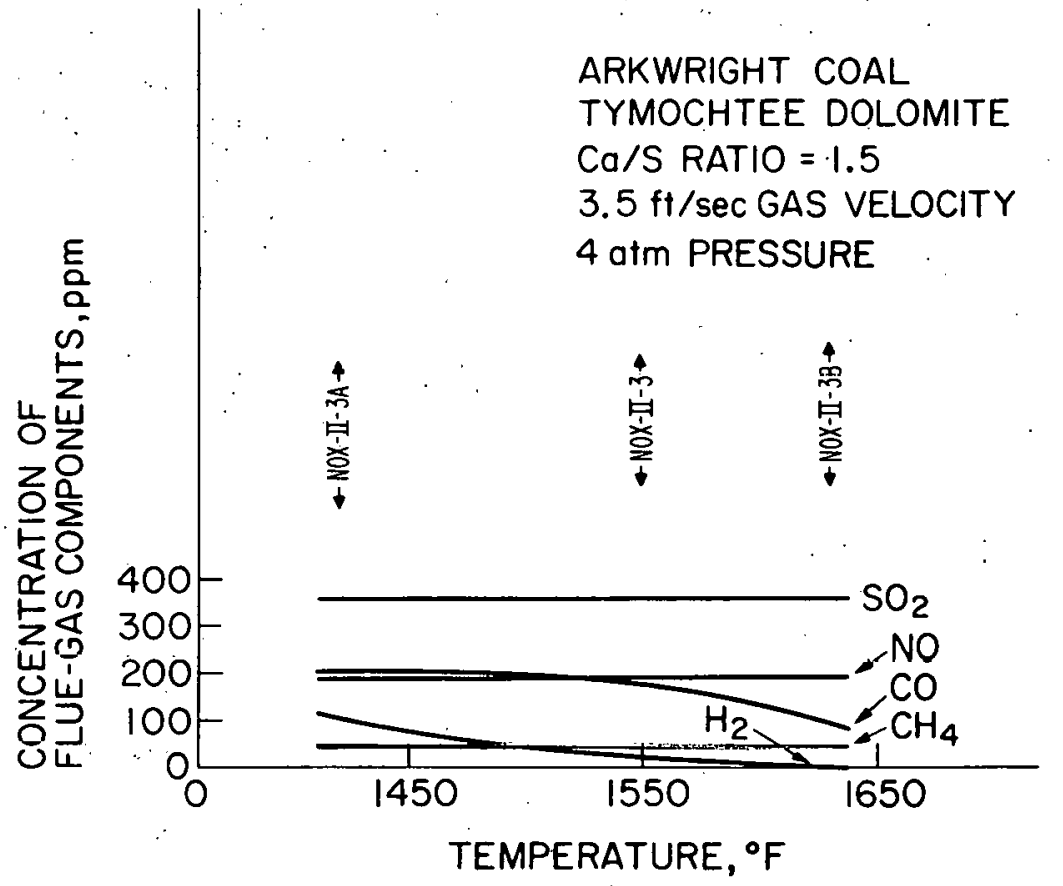

Figure 21. Effect of Temperature on Concentration of Flue-Gas Components 
A study is being made of the distribution and potential emissions of biologically toxic trace elements during the fluidized-bed combustion of coal. Interest in the emissions of such elements as $\mathrm{Hg}, \mathrm{Be}, \mathrm{Pb}$, and $F$ has increased considerably in recent years. Although these elements are present at very low levels in fossil fuels, the large consumption of these fuels in the United States represents an annual potential emission release of up to several thousand tons for some of the elements.

Since most of the trace elements in coal are 11kely to be found in the sorbent used for $\mathrm{SO}_{2}$ removal, there is some interest in comparing the behavior of the trace elements in a fluidized-bed combustor with con. ventional, coal-fired power stations. Relative to conventional bollers, the lower combustion temperatures of the fluidized-bed bollor and the presence of additive for $\mathrm{SO}_{2}$ retention may serve to retain potentially volatile trace elements in particulate form. The elements of interest are 1isted in Table 16 in order of their priority as pollution agents as determined by the EPA.

Four combustion experiments have been completed to study the distribution of trace elements in the combustion system. The approach being taken is to make mass balances around the combustion system for as many of the trace elements as possible within the economic limitations of the study. This involves sampling and analyzing all the solid materials charged to or recovered from the combustion system, including particulate matter entrained in the flue gas. The flue gas is also analyzed for the more volatile trace-element species, Hg and $\mathrm{F}^{-}$.

Table 16. Trace Elements of Interest and Their Order of Priority for Experimental Investigation

First Priority

Beryliium

Mercury

Fluorine

Lead

Second Priority

Cadmium

Arsenic

Nickel
Third Priority
Copper
Zinc
Barium
Tin
Phosphorus
L1thium
Vanadium
Manganese
Chromtum
Selenium 
Solids Sampling

The mass balances are made over the duration of the combustion experiments and not just over a specific interval of time. Inputs to the mass balance, therefore, consisted of the initial bed charge (either Alundum or partially sulfated additive from a previous combustion experiment), the coal fed to the combustor and, for experiments with a bed of additive, the sorbent fed to the combustor. Outputs from the system consisted of the final bed, overflow material removed through the standpipe, and entrained solids from the combustor recovered in the primary cyclone, secondary cyclone, primary filter, and secondary filter.

With the exception of the coal and additive feeds, samples submitted for analysis were obtained by splitting or core sampling the bulk materials. Because of the large volume of coal and additive used during a single experiment, samples of these materials consisted of randomly taken grab samples, which were combined into a single sample for analysis. All samples were ground to a powder using a mortar and pestle to promote homogeneity before further dividing the samples for the individual analyses.

\section{Flue-Gas Sampling}

Whereas the solids were sampled prior to and at the conclusion of the experiment, the flue gas was sampled over an interval of time during the course of the experiment. The flue gas was sampled after it had passed through the principal gas-solid separators, which remove nearly all of the particulate matter above $5 \mu \mathrm{m}$ in diameter, and through the pressure let-down valve: This had the advantage of allowing the sampling to be accomplished at atmospheric pressure, even though the combustor and the ancillary equipment were operating at pressures of up to $10 \mathrm{~atm}$.

The modifications made in the flue-gas line to accommodate the sampling process are indicated in Fig. 22. The sampling zone is a 5-ft length of 4-in.-dia, Type L copper tube with a nominal inside diameter of 3.905 in. The sample probe is located approximately 12-pipe diameters downstream and 3-pipe diameters upstream from any flow disturbances.

Sampling of the flue gas for particulate matter and gas phase $\mathrm{Hg}$ and $\mathrm{F}^{-}$was made using the apparatus illustrated in Fig. 23. The sample probe was constructed from 1/4-in., Type 304 stainless steel . tubing. A tapered nozzle with a 5/32-in. opening was affixed to the end of the probe to provide for streamlined sampling. The probe could be inserted to any depth along the diameter of the flue to allow for sampling at several traverse points. However, because of the relatively small diameter of the flue, the highly turbulent gas flow, and the location of the probe away from flow disturbances, sampling was done only at the centerline of the flue. Thus the assumption made in sampling was that the concentrations of interest were not a significant function of radial position. 


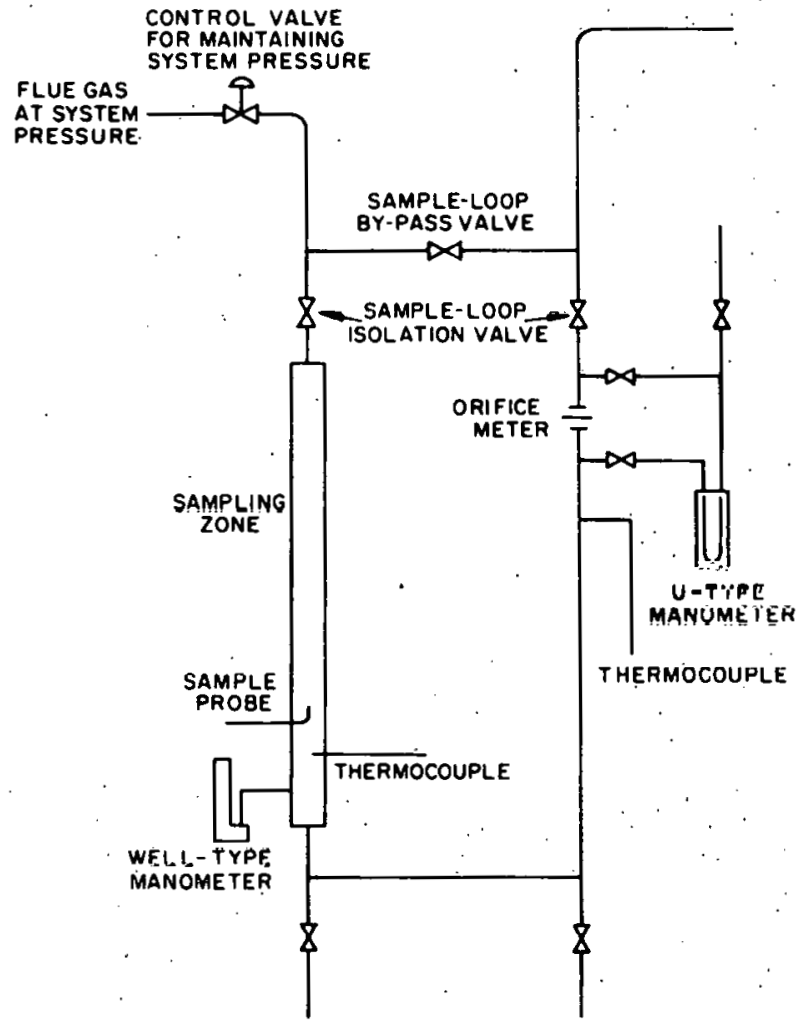

Figure 22. Experimental Flow System for Flue-Gas Sampling

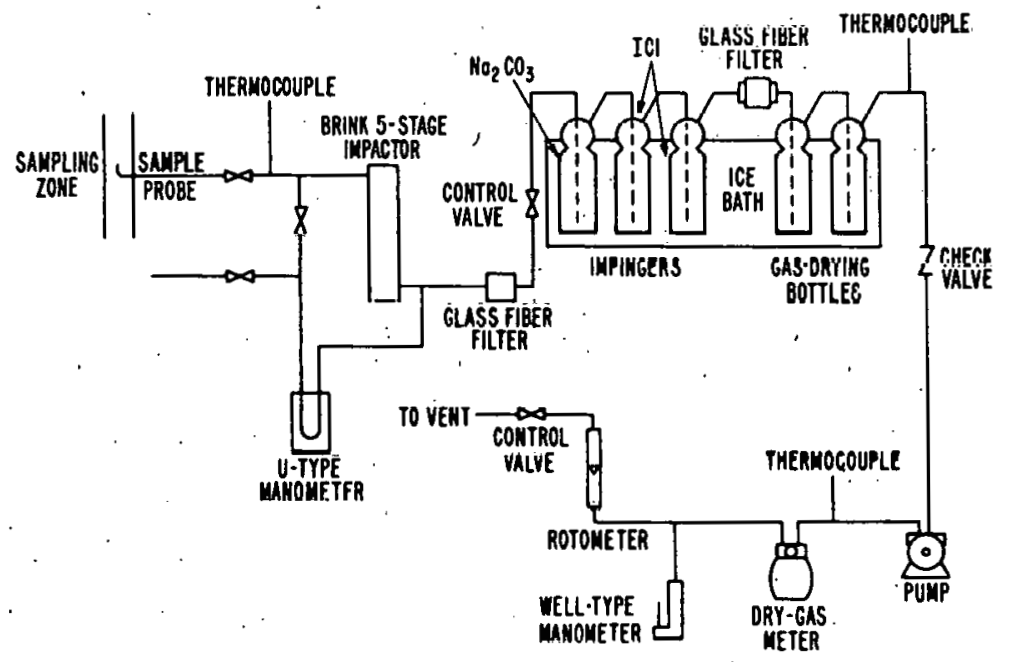

Figure 23. Flue-Gas Sampling Apparatus for Measuring Concentrations of $\mathrm{Hg}, \mathrm{F}^{-}$, and Entrained Particulate Matter 
The particulate matter in the gas sample was removed in the Brink Cascade Impactor (in-1ine cyclone +5 stages) and the follow-up, glassfiber filter (Gelman Type A). The impactor removed and separated the particulate matter into five size ranges, which covered the range from $\sim 0.3$ to $3.0 \mu \mathrm{m}$ in diameter. The sample probe, impactor, and filter housing were heated to over $250^{\circ} \mathrm{F}$ to prevent condensation of the $\mathrm{Hg}$ and $\mathrm{F}^{-}$on the metal surfaces.

The sample of flue gas, after removal of the particulate matter, passed through a series of scrubbers in an ice bath to remove the volatile $\mathrm{F}^{-}$and $\mathrm{Hg}$ compounds. The first scrubber contained $\sim 400 \mathrm{ml}$ of either a 1 wt \% $\mathrm{NaHCO}_{3}$ or saturated $\mathrm{Na}_{2} \mathrm{CO}_{3}$ solution to remove the $\mathrm{F}^{-}$. The second and third scrubbers each contained $\sim 100 \mathrm{ml}$ of a $0.1 \mathrm{M}$ iodine monochloride (IC1) solution for removing the gas-phase $\mathrm{Hg}$. In two of the four combustion experiments, the first IC1 scrubber was replaced by a straight section of glass tubing containing two frits of compactly wound fine gold wire. Because gold is an excellent amalgamator of $\mathrm{Hg}$, it was anticipated that the $\mathrm{Hg}$ in the flue-gas sample passing through the first scrubber would be trapped by the gold. The second ICl scrubber was retained to serve as a back-up for the gold frits.

The volumetric flow rate of the gas sample through the impactor and scrubbing solutions ranged from 0.1 to $0.15 \mathrm{cfm}$.

\section{Analytical Methods}

Mercury and lead are being determined by atomic absorption spectroscopy, fluoride by specific ion electrode, and beryllium by fluorimetry. Neutron activation analysis methods are also being developed as an instrumental method for analyzing as many of the second and third priority elements as possible. Detailed analytical procedures currently being used for the various trace elements and types of samples (solutions, coal, ash, and additive) are presented in detail in Appendix $\mathbf{E}$.

\section{Results}

As indicated above, four combustion experiments were made for the specific purpose of investigating the behavior of trace elements during combustion. A summary of the average operating conditions and flue-gas compositions for the trace-element experiments are presented in Table 17. Nominal conditions for experiments TRACE-3 and TRACE-4B were a bed temperature of $1550^{\circ} \mathrm{F}, 10$ atm pressure, and $4 \% \mathrm{O}_{2}$ in the off-gas as compared with values of $1650^{\circ} \mathrm{F} ; 8 \mathrm{~atm}$, and $3 \% \mathrm{O}_{2}$ for experiments TRACE-5A and TRACE-6. At each set of conditions, one experiment Involved the combustion of Arkwright coal in a fluidized bed of Alundum, whereas the other experiment involved the combustion of Arkwright coal in a fluidized bed of Tymochtee dolomite. 
Table 17. Summary of Average Operating Conditiors and Flue-Gas Compositions for Trace-Element Experiments ${ }^{a}$

\begin{tabular}{|c|c|c|c|c|c|c|c|c|c|c|c|c|c|}
\hline \multirow[b]{2}{*}{ Expt. } & \multirow{2}{*}{$\begin{array}{l}\text { Run } \\
\text { Time, } \\
\text { hr }\end{array}$} & \multirow{2}{*}{$\begin{array}{l}\text { Bed } \\
\text { Tenp, } \\
{ }^{\circ} F\end{array}$} & \multirow{2}{*}{$\begin{array}{c}\text { System } \\
\text { Pressure, } \\
\text { atm }\end{array}$} & \multicolumn{3}{|c|}{ Feed Rates } & \multirow[b]{2}{*}{$\begin{array}{l}\mathrm{Ca} / \mathrm{S} \\
\text { Ratio }\end{array}$} & \multirow{2}{*}{$\begin{array}{c}\text { Gas } \\
\text { Velocity, } \\
\text { ft!sec }\end{array}$} & \multicolumn{5}{|c|}{$\begin{array}{c}\text { Flue-Gas Analysis: } \\
\text { Dry Basis }\end{array}$} \\
\hline & & & & $\begin{array}{l}\text { Coal, } \\
\text { lb/hr }\end{array}$ & $\begin{array}{c}\text { Dolomite, } \\
\text { lb/hr }\end{array}$ & $\begin{array}{l}\text { Air, } \\
\text { scfm }\end{array}$ & & & $\begin{array}{c}\mathrm{O}_{2} \\
\%\end{array}$ & $\underset{\%}{\mathrm{CO}_{2}}$ & $\begin{array}{l}\mathrm{SO}_{2} \\
\mathrm{ppm}\end{array}$ & $\begin{array}{l}\text { No, } \\
\text { ppm }\end{array}$ & $\begin{array}{l}\text { Co, } \\
\text { ppm }\end{array}$ \\
\hline & (Exper & imersts & a Fluid & ed Bed & of Alumina & & & & & & & & \\
\hline $\begin{array}{l}\text { TRACE-5A } \\
\text { TRACE-3 }\end{array}$ & $\begin{array}{l}6.0 \\
4.0 \\
\text { (Exper }\end{array}$ & $\begin{array}{l}1670 \\
156.0 \\
\text { imerts }\end{array}$ & $\begin{array}{l}8 \\
10 \\
\text { in a Fluidi }\end{array}$ & $\begin{array}{r}29.4 \\
24.9 \\
\text { zed Bed }\end{array}$ & $\begin{array}{c}0.0 \\
0.0 \\
\text { of Tymoc }\end{array}$ & $\begin{array}{l}67.1 \\
63.0\end{array}$ & $\begin{array}{l}0.0 \\
0.0\end{array}$ & $\begin{array}{l}3.3 \\
2.4\end{array}$ & $\begin{array}{l}3.0 \\
3.9\end{array}$ & $\begin{array}{l}16.0 \\
16.1\end{array}$ & $\begin{array}{l}2180 \\
1660^{b}\end{array}$ & $\begin{array}{l}110 \\
180\end{array}$ & $\begin{array}{r}70 \\
120\end{array}$ \\
\hline $\begin{array}{l}\text { TRACE-6 } \\
\text { TRACE-4B }\end{array}$ & $\begin{array}{l}7.5 \\
4.75\end{array}$ & $\begin{array}{l}1660 \\
1550\end{array}$ & $\begin{array}{r}8 \\
10\end{array}$ & $\begin{array}{l}29.7 \\
28.2\end{array}$ & $\begin{array}{r}6.1 \\
14.2\end{array}$ & $\begin{array}{l}67.9 \\
75.5\end{array}$ & $\begin{array}{l}1.2 \\
2.9\end{array}$ & $\begin{array}{l}3.4 \\
3.0\end{array}$ & $\begin{array}{l}2.9 \\
3.8\end{array}$ & $\begin{array}{l}16.5 \\
19.0\end{array}$ & $\begin{array}{l}440 \\
140\end{array}$ & $\begin{array}{l}150 \\
200\end{array}$ & $\begin{array}{l}39 \\
35\end{array}$ \\
\hline
\end{tabular}

${ }_{\text {all }}$ experiments made with as-received Arkwright coal.

${ }^{b_{L}}$ Low value due to malfunction of $\mathrm{SO}_{2}$ IR analyzer. 
Mercury Mass Balances. Mercury balances for the four experiments are presented in Table 18. Experiments TRACE-3 and TRACE-4B, which were completed first (with two ICl scrubbers in the gas-sampling apparatus), exhibited $\mathrm{Hg}$ recoveries, expressed as the percentage of $\mathrm{Hg}$ entering the combustor which can be accounted for in the combustion products, of 56 and $43 \%$, respectively. For experiments TRACE-5A and TRACE-6 (with two gold frits and one IC1 scrubber in the gas sampling apparatus) the respective recoveries were only 29 and $25 \%$. The lower total $\mathrm{Hg}$ recovery values for the latter experiments apparently resulted from the decreased reçovery of $\mathrm{Hg}$ in the volatile form, which was lower by a factor of 6 as compared with the earlier experiments ( 3 and $5 \%$ vs. 19 and 34\%). The amount of $\mathrm{Hg}$ recovered in the solid-phase combustion products ranged from 9 to $37 \%$ with an average recovery of $23 \%$ for the four experiments.

Measured concentrations of $\mathrm{Hg}$ in the flue gas for experiments TRACE-5A and TRACE-6 (made at $1650^{\circ} \mathrm{F}$ ) were only 0.03 and $0.05 \mathrm{ppb}$ as compared with 0.32 and $0.66 \mathrm{ppb}$ for experiments TRACE-3 and TRACE-4B (made at $1550^{\circ} \mathrm{F}$ ). It would seem more logical to expect an increase in the level of $\mathrm{Hg}$ in the flue gas at the higher combustion temperatures. The lower measured concentrations did not, however, appear to result from the modifications in the flue-gas sampling equipment discussed above. In the experiments with the modified apparatus, traces of $\mathrm{Hg}$ were found in the carbonate solution (considerably less than in the first two experiments, however), on the gold frits, and on the f1lter following the IC1 scrubbing solution: As with the first two experiments, no $\mathrm{Hg}$ was detected in the ICl solution.

Several attempts have been made to determine the cause for the poor recovery of $\mathrm{Hg}$ in the combustion products. The particular question areas that have been or are being examined include the following:

(1) The inability to detect mercury in the IC1 scrubbing solutions used in sampling the flue gas.

(2) The recovery efficiency of the mercury sampling equipment.

(3) The possibility that mercury is plating out or condensing on the walls of the flue-gas ductwork before reaching the sampling zone.

Efforts that have been expended to define the problems are discussed below. 
Table 18. Mercury Material. Balances for Trace-Element Comtustion Experiments

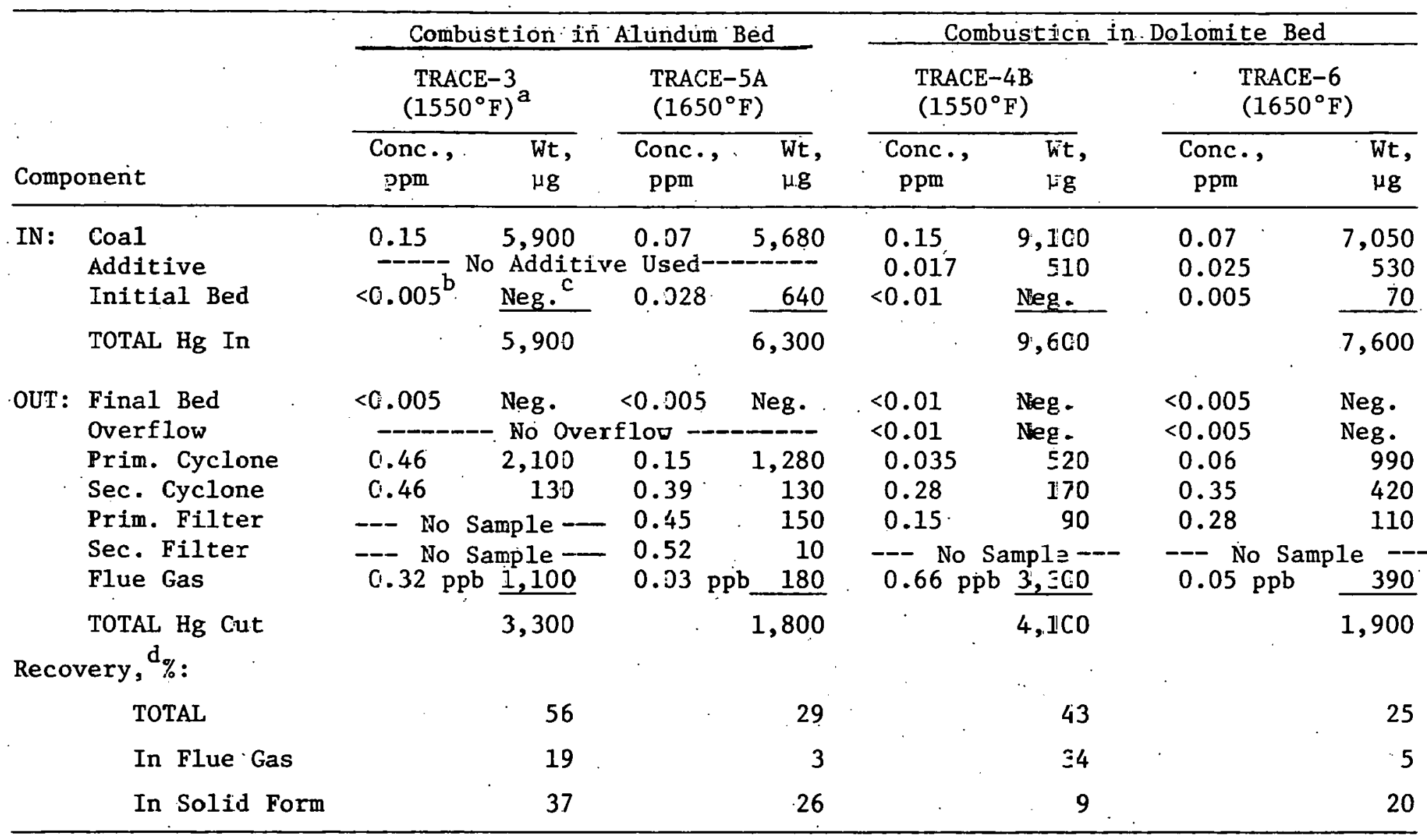

$a_{\text {Bed temperature. }}$

bstimated.

${ }^{c}$ Considered negligible.

$\mathrm{d}_{\text {Recovery }}=(\mathrm{Hg}$ out $/ \mathrm{Hg}$ in) $\times 100 \%$. 
Iodine Monochloride Scrubbing Solution. Sulfur dioxide has been reported as interfering with the detection of $\mathrm{Hg}$ in gas streams when using ICl or $\mathrm{K}_{2} \mathrm{MnO}_{4}$ scrubbing solutions. ${ }^{8}$ To test this, $\mathrm{SO}_{2}$ was bubbled through an ICI solution containing a known concentration of Hg. Samples were taken of the ICl solution at various times and analyzed for $\mathrm{Hg}$. The $\mathrm{Hg}$ concentration remained constant, thereby indicating no interference from the $\mathrm{SO}_{2}$. However, excessive exposure to $\mathrm{SO}_{2}$ can cause $\mathrm{I}_{2}$ or $\mathrm{MnO}_{2}$ precipitation, which then makes analysis of the solutions for $\mathrm{Hg}$ impossible. This, however, explains the inability to detect $\mathrm{Hg}$ in the IC1 scrubber in only the TRACE-3 experiment.

In subsequent tests, it was observed that if the IC1 solution is first exposed to flue gas, then trace quantities of $\mathrm{Hg}$ subsequently added to the solution cannot be detected. Recovery is generally less than $50 \%$. Trace amounts of $\mathrm{Hg}$ added to ICl solutions unexposed to flue gas, however, exhibit $100 \%$ recovery of the $\mathrm{Hg}$ by analysis. This strongly suggests that components in the flue gas other than $\mathrm{SO}_{2}$ may be interfering with the $\mathrm{Hg}$ analysis in the ICl solutions.

\section{Condensation of Mercury on Flue-Gas Ductwork. Several tests} have been made and additional tests are in progress to determine the possibility that $\mathrm{Hg}$ condenses on the walls of the ductwork before it reaches the sampling zone. Copper and stainless-steel tabs were suspended in the flue gas just upstream from the sampling probe during a typical combustion experiment. When analyzed for mercury at the end of the experiment, the concentrations of $\mathrm{Hg}$ on the copper and stainless steel tabs, respectively, were 0.7 and $0.2 \mathrm{ppm}$. Copper and stainless steel tabs which had not been suspended in the flue gas exhibited $\mathrm{Hg}$. concentrations of $\sim 2.5$ and $0.2 \mathrm{ppm}$, respectively, indicating that the $\mathrm{Hg}$ on the test pieces was not $\mathrm{Hg}$ which had condensed out of the flue gas.

The fiber filters used in cleaning the flue gas of particulate matter were also examined. Indications were that any mercury on the filters was associated with the particulate matter trapped on the filters.

Scrapings were also taken from the walls of the flue-gas piping and analyzed to determine whether abnormally high levels of $\mathrm{Hg}$ were present there. The samples did have $\mathrm{Hg}$ concentrations approximately an order of magnitude higher than the combustion products recovered in the cyclones and filters. It is doubtful, however, that enough $\mathrm{Hg}$ accumulates in the piping to explain the ponr recoveries of $\mathrm{Hg}$ reported for the TRACE experiments.

Efficiency of Mercury Sampling Apparatus. Plans are to inject a known amount of $\mathrm{Hg}$ into the flue-gas sampling line during a future combustion experiment at a point just upstream of the sampling apparatus and determine the mercury material balance. This should help to determine whether the problems are with the sampling of the flue gas or whether the $\mathrm{Hg}$ is condensing out in the system before reaching the sampling localion. 
Retention of Mercury in Solid Products of Combustion. The recovery of mercury in the solid combustion products is in keeping with results reported by other investigators. Billings et al. made a mercury balance around a 660 MWe coal-fired power station using a coal containing $21 \%$ ash $(<1 \% \mathrm{~S})$ and having a heating value of $29000 \mathrm{BTU} / 1 \mathrm{~b} .9$ They reported that $\sim 10 \%$ of the mercury remained with the furnace residual ash, and $90 \%$ was emitted in the vapor phase. The average concentrations of $\mathrm{Hg}$ in the coal and ash products were $0.3 \mathrm{ppm}$ and $0.2 \mathrm{ppm}$, respectively.

It is interesting to note that the fly-ash samples in the study by Billings et al. were less concentrated in $\mathrm{Hg}$ than the coal being combusted, whereas in the TRACE experiments the elutriated solids were consistently higher in $\mathrm{Hg}$ concentration than the coal (except for primary cyclone samples highly diluted with sulfated dolomite). This is reflected in the higher retention of $\mathrm{Hg}$ by the ash products ( 37 and $26 \%$ reported for the TRACE experiments made with an Alundum bed. This . is an indication, at least, that fluldized-bed combuotion may offer the potential for increased retention of mercury by the sulid producto of combustion.

Dieh1 et al. have also studied the fate of $\mathrm{Hg}$ during the combustion of coal in combustion units of various sizes. 10 In a $100-\mathrm{g} / \mathrm{hr}$ test unit, $260 \%$ of the mercury was retained in the fly ash (combustion at $2100^{\circ} \mathrm{F}$ ) when burning a coal containing $0.15 \mathrm{ppm} \mathrm{Hg}$ ( $0.9 \mathrm{ppm}$ in the ash). Approximately, 35\% of the mercury was retained in the fly ash when burning a coal containing $0.24 \mathrm{ppm} \mathrm{Hg}(\sim 0.35 \mathrm{ppm}$ in the ash). In a 500-1b/hr combustor burning pulverized coal containing $0.18 \mathrm{ppm} \mathrm{Hg}$, ash removed in cyclones at $\sim 360^{\circ} \mathrm{F}$ contained $0.22 \mathrm{ppm} \mathrm{Hg}$, which accounted for $\sim 12 \%$ of the $\mathrm{Hg}$ in the coal. They also sampled fly ash from 250 MWe and 175 MWe power plants, and reported mercury contents in the ash of 0.10 and $0.26 \mathrm{ppm}$, respectively, for estimated $\mathrm{Hg}$ retentions of 7 and $19 \%$ in the fly ash.

Lead and Berylli.um Mass Balances. Lead balances for the four tracc-clcment experiments are prespented in Table 19, The material balances range from 78 to $125 \%$ recovery of the lead entering the combustor. Beryllium balances for the trace-element experiments are presented in Table 20. Recoveries of Be were somewhat lower than for the $\mathrm{Pb}$, ranging from 56 to $87 \%$.

The results strongly indicate that the lead, with the observed high recoveries, is essentially retained by the particulate matter in the combustion products. Emissions of $\mathrm{Pb}$, therefore, will be controlled by the efficiency of particulate removal from the flue gas. However, because the concentration of $\mathrm{Pb}$ in particulate matter increases with decreasing particle size, the efficiency of lead removal will be somewhat lower than the overall efficiency of particulate removal.

The beryllium mass balances, with the lower recoveries, suggest the possible volatilization of beryllium (or compounds of beryllium) during combustion. This seems an unlikely possibility, however, for the bed temperatures used in these combustion experiments. 
Table 19. Lead Material Balances for Trace-Element Combustion Experiments

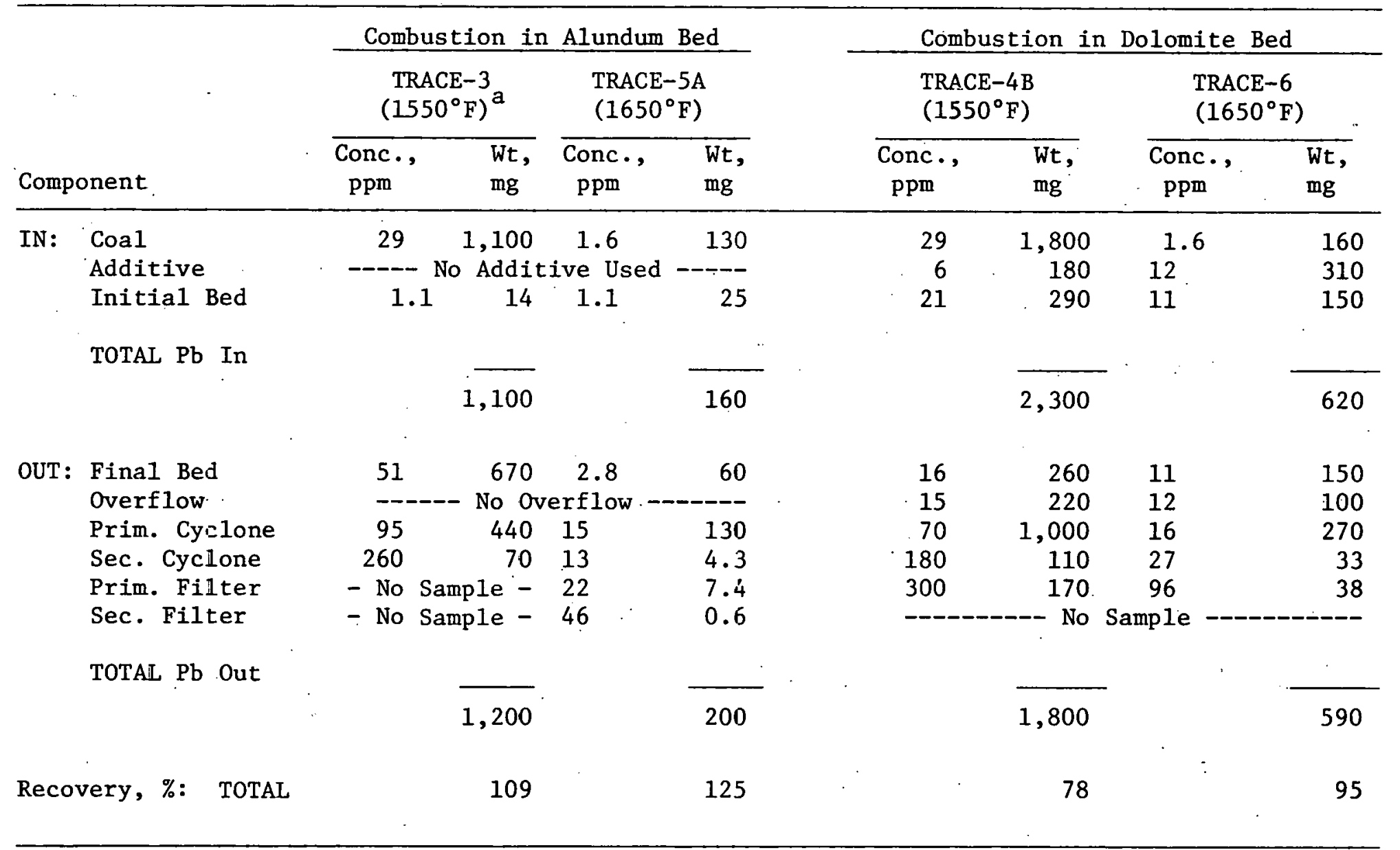

\footnotetext{
$a_{\text {Bed temperature. }}$
} 
Table 20. Beryllium Material Balances for Trace-Element Combustion Experiments

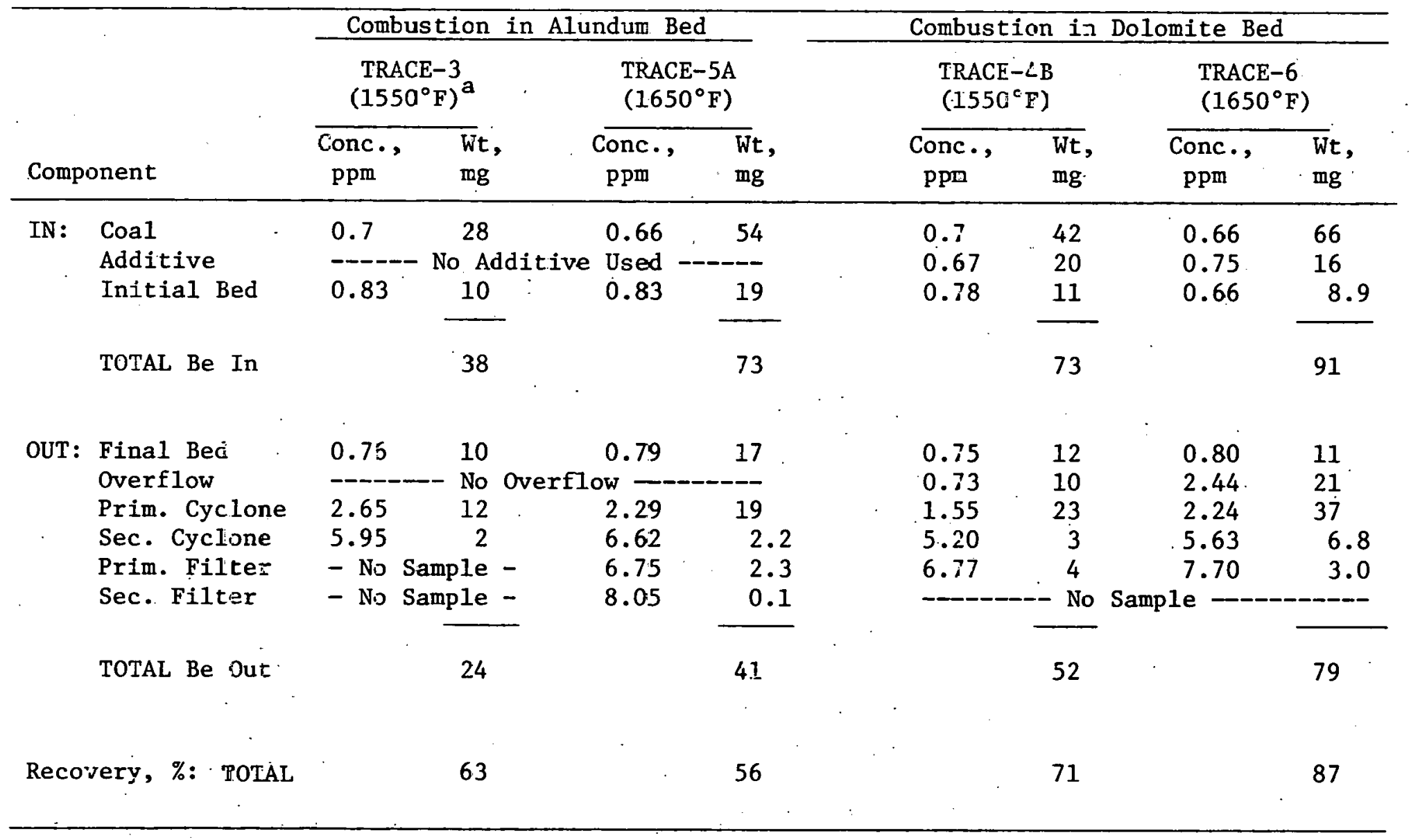

$a_{\text {Bed temperatire. }}$ 
Preferential Concentration of Lead and Beryllium in the Finer Particulate Matter. Aside from materia1-balance considerations, the results indicate that both lead and beryllium concentrate preferentially in the finer particles leaving the combustor. Figure 24 shows Coulter Counter particle-size analysis curves for the primary and secondary cyclone materials as recovered from the TRACE- 3 experiment. The combustion gases leaving the combustor pass through a primary cyclone, a secondary cyclone, and a porous filter, in that order. A $50 \%$ cutoff value of approximately $10 \mu \mathrm{m}$ was obtained from Fig. 24 for the "mean" diameter of the primary cyclone material. A "mean" value of $1.5 \mu \mathrm{m}$ was found for the diameter of the secondary cyclone material. For the coarser primary-cyclone ash product, the lead and beryllium concentrations were 95 and $2.65 \mathrm{ppm}$, respectively. In the finer, secondarycyclone ash, the lead and beryllium concentrations increased to 255 and $5.94 \mathrm{ppm}$, respectively.

Although particle-size data are not available for the primary and secondary cyclone and filter solids from the other trace-element experiments, we can infer from the concentration data for $\mathrm{Pb}$ and $\mathrm{Be}$ in Tables 19 and 20 a definite trend of increasing trace-element concentration in the finer fractions of the material recovered from the flue gas.

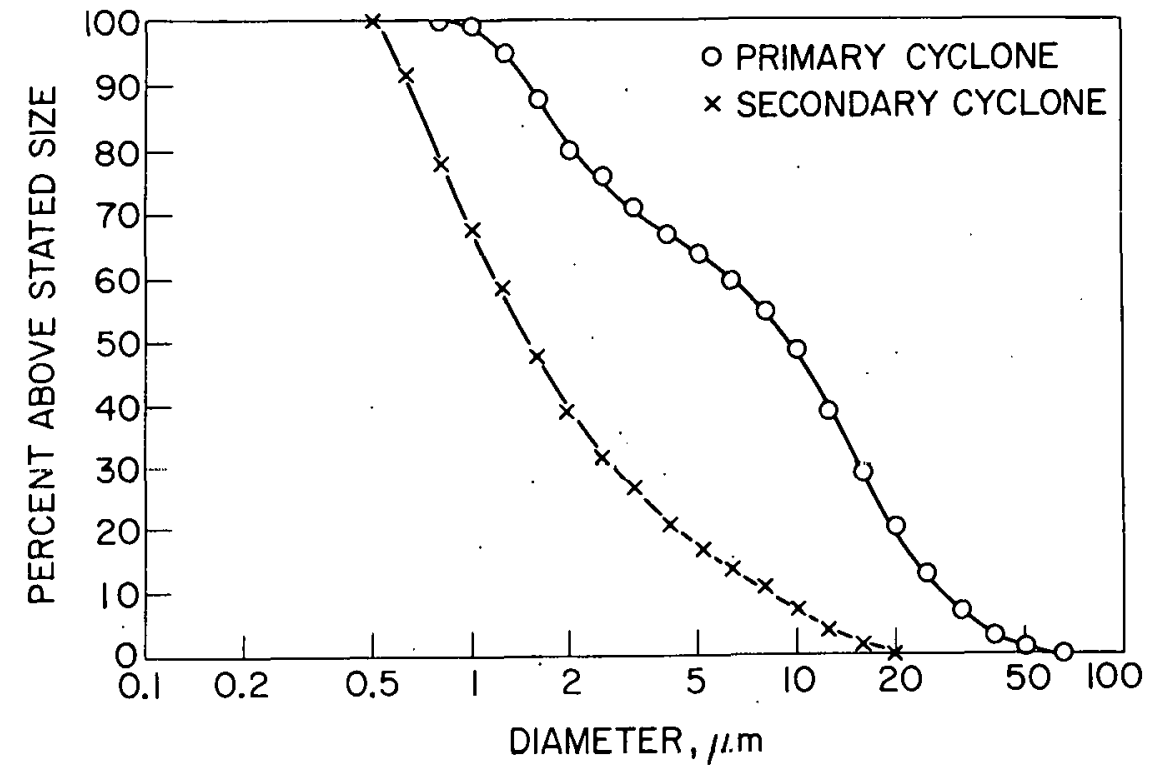

Figure 24. Yarticle-Size Distributions for Fly Ash Recovered by the Primary and Secondary Cyclones in Experiment TRACE-3 
The preferential concentration of relatively nonvolatile trace elements in particles of smaller diameter has been demonstrated in samples taken from ambient air 11,12 and more recently in fly-ash particles retained in the precipitation systems and in the airborne fly ash leaving eight different coal-fired power plants in the United States. 13 It has been proposed that preferential concentration occurs by volatilization of the elements (or one of their compounds) during combustion, followed by condensation or adsorption onto the larger surface area, per unit mass, of the smaller particles. 13 It was noted that the normal temperature in the combustion zones of the conventional plants tested was between $1300^{\circ}$ and $1600^{\circ} \mathrm{C}$, a temperature similar to or above the boiling points of the elements investigated ( $\mathrm{Cd}, \mathrm{As}, \mathrm{Ni}$, $\mathrm{Pb}, \mathrm{Cr}$, and $\mathrm{Zn}$ ).

Although our results appear to confirm the preferential concentration of $\mathrm{Pb}$ and $\mathrm{Be}$ in smaller particles; there is 1ittle evidence to support the idea of volatilization and subsequent condensation or absorption as the mechanism by which this concentration occurs. In a report by the Illinois Geological Survey, it was shown that there was no significant loss of beryllium in coal ash prepared at $700^{\circ} \mathrm{C} .14$ As the TRACE-3. and TRACE-4B experiments were carried out at 10-atm pressure and a bed temperature of only $850^{\circ} \mathrm{C}$, it does not appear likely that volatilization would be a significant factor in the apparent concentration of the beryllium in the finer particles. A somewhat simpler explanation may be that the trace elements in the larger particles are simply diluted by unburned carbonaceous materials. This is evidenced in Table 21, which tabulates the concentrations of trace, minor, and major elements in particulate matter recovered during the TRACE experiments at various stages of removal from the flue gas. As experiments TRACE- 3 and TRACE-5A were made using an Alundum bed, the changes in concentration with subsequent stages of solids recovery from the flue gas are not biased by the presence of large amounts of additive. In the TRACE- 3 experiment, the level of carbon decreases from 51.3 to $29.2 \%$ as the concentrations of the trace and minor elements in the coal increase in the ash. In experiment TRACE-5A, the concentration of carbon decreases from 34.1 to $6.6 \%$ as the levels of the other elements show concentration increases.

An interesting observation can also be made by comparing the ratios of lead to beryllium in the coal, additive, and in each of the materials removed at various stages of the gas cleanup system. These ratios are presented in Table 22 .

The columns of particular interest are those under experiments TRACE- 3 and TRACE-5A, in which additive does not appear as a factor in the calculated ratios. While there does appear to be some variation in the ratio of $\mathrm{Pb}$ to $\mathrm{Be}$, theee variations could well fall within the accuracies of the analytical methods. If volatilization and condensation are the mechanisms by which preferential concentration occurs, it seems likely that the $\mathrm{Pb}-$ to-Be ratio would change significantly over the range of samples analyzed. 
Table 21. Concentrations of Trace, Minor, and Major Elements in Particulate Matter Recovered at Various Stages of Removal from Flue Gas

\begin{tabular}{|c|c|c|c|c|c|}
\hline \multirow[b]{2}{*}{ Source of Solids } & \multicolumn{5}{|c|}{ Concentration } \\
\hline & $\begin{array}{l}\mathrm{Pb}, \\
\mathrm{ppm}\end{array}$ & $\begin{array}{l}\mathrm{Be} \\
\mathrm{ppm}\end{array}$ & $\begin{array}{c}c \\
\text { wt } \%\end{array}$ & $\begin{array}{l}\text { s, } \\
\text { wt \% }\end{array}$ & $\begin{array}{l}\mathrm{Ca}, \\
\text { wt \% }\end{array}$ \\
\hline . & \multicolumn{5}{|c|}{ (Experiment TRACE-3) } \\
\hline $\begin{array}{l}\text { Primary Cyclone } \\
\text { Secondary Cyclone } \\
\text {. }\end{array}$ & $\begin{array}{r}95 \\
260\end{array}$ & $\begin{array}{l}2.65 \\
5.95\end{array}$ & $\begin{array}{l}51.3 \\
29.2\end{array}$ & $\begin{array}{l}0.86 \\
1.80\end{array}$ & $\begin{array}{l}1.29 \\
1.80\end{array}$ \\
\hline & \multicolumn{5}{|c|}{ (Experiment TRACE-4B) } \\
\hline $\begin{array}{l}\text { Primary Cyclone } \\
\text { Secondary Cyclone } \\
\text { Filter }\end{array}$ & $\begin{array}{r}70 \\
180 \\
300\end{array}$ & $\begin{array}{l}1.55 \\
5.20 \\
6.77\end{array}$ & $\begin{array}{r}2.3 \\
13.1 \\
8.4\end{array}$ & $\begin{array}{l}4.5 \\
2.6 \\
3.1\end{array}$ & $\begin{array}{r}15.4 \\
5.58 \\
6.65\end{array}$ \\
\hline & \multicolumn{5}{|c|}{ (Experiment TRACE-5A) } \\
\hline $\begin{array}{l}\text { Primary Cyclone } \\
\text { Secondary Cyclone } \\
\text { Primary Filter } \\
\text { Secondary Filter }\end{array}$ & $\begin{array}{l}15 \\
13 \\
22 \\
46\end{array}$ & $\begin{array}{l}2.29 \\
6.62 \\
6.75 \\
8.05\end{array}$ & $\begin{array}{r}34.1 \\
16.8 \\
6.6 \\
---\end{array}$ & $\begin{array}{l}1.8 \\
2.5 \\
4.9 \\
----\end{array}$ & $\begin{array}{l}2.11 \\
2.02 \\
2.89 \\
-\end{array}$ \\
\hline & \multicolumn{5}{|c|}{ (Experiment TRACE-6) } \\
\hline $\begin{array}{l}\text { Primary Cyclone } \\
\text { Secondary Cyclone } \\
\text { Primary Filter }\end{array}$ & $\begin{array}{l}16 \\
27 \\
96\end{array}$ & $\begin{array}{l}2.24 \\
5.63 \\
7.70\end{array}$ & $\begin{array}{r}19.6 \\
11.3 \\
5.2\end{array}$ & $\begin{array}{l}4.8 \\
3.1 \\
4.3\end{array}$ & $\begin{array}{l}8.11 \\
4.89 \\
5.44\end{array}$ \\
\hline
\end{tabular}

Table 22. Ratio of Lead to Beryllium in the Raw Materials and in the Particulate Matter Removed from the Flue Gas during the "TRACE" Experiments

\begin{tabular}{|c|c|c|c|c|}
\hline \multirow[b]{2}{*}{ Material } & \multicolumn{4}{|c|}{ Experiment } \\
\hline & TRACE-3 & TRACE-4B & TRACE-5A & TRACE-6 \\
\hline Coal & 41 & 41 & 2.4 & 2.4 \\
\hline Additive & not used & 9 & not used & 16 \\
\hline $\begin{array}{l}\text { Primary Cyclone } \\
\text { Secondary }\end{array}$ & 36 & 45 & 6.5 & 7.1 \\
\hline Cyclone & 43 & 34 & 2.0 & 4.8 \\
\hline $\begin{array}{l}\text { Primary Filter } \\
\text { Secondary }\end{array}$ & no sample & 44 & 3.3 & 12 \\
\hline Filter & no sample & no sample & 5.7 & no sample \\
\hline
\end{tabular}


Fluoride Mass Balances. Fluoride material balances for the traceelement experiments are given in Table 23. The indicated recovery of fluoride for the experiments at $1550^{\circ} \mathrm{F}$ are 123 and $110 \%$, which are reasonably acceptable values. The recoveries of 208 and $276 \%$ reported for the experiments at $1650^{\circ} \mathrm{F}$, however, are unaccountably high. The only differences in sampling between the two sets of experiments were the use of considerably larger flue-gas samples and the use of $\mathrm{Na}_{2} \mathrm{CO}_{3}$ scrubbers instead of $\mathrm{NaHCO}_{3}$ scrubbers for the experiments at $1650^{\circ} \mathrm{F}$.

Perhaps the most significant observation that can be made from the $\mathrm{F}^{-}$balances is that the retention of the $\mathrm{F}^{-}$in the solid phases leaving the combustor appeared to be significantly higher when additive was used in the experiment. The reported recoveries of $\mathrm{F}^{-}$in the solid samples were 56 and $62 \%$ for combustion with additive present and only 23 and $5 \%$ for combustion in an Alundum bed. A possible explanation for such a phenomenon could be the formation of. CaF, which is a rclatively stuble compound.

Neutron Activation Analysis, Developmental Work. Neutron activation analysis is being considered as a possible instrumental method for expanding the trace-element study to include elements of second- and third-priority interest $(\mathrm{Cd}, \mathrm{As}, \mathrm{Ni}, \mathrm{Zn}, \mathrm{Cu}, \mathrm{Ba}, \mathrm{Sn}, \mathrm{P}$, $\mathrm{Li}, \mathrm{Mn}, \mathrm{Cr}, \mathrm{Se}$, and $\mathrm{V}$ ). A preliminary testing of the method was made by taking $100-\mathrm{mg}$ samples of coal, TRACE-3 primary-cyclone ash, and TRACE-3 secondary-cyclone ash and irradiating them in the ANL CP-5 test reactor for $2.5 \mathrm{hr}$. Flux monitors irradiated with the samples. revealed that neutron exposure of the samples was considerably lower than had been anticipated. Subsequent inquiries indicated that an error may have occurred in positioning the samples in the reactor; this would account for the low measured neutron flux.

After the irradiation, periodic $\gamma$-ray counts were taken using a $\mathrm{Ge}(\mathrm{Li})$ detector on all three samples for the purpose of identification of activation products and relative activity levels. Results for seven of the elements detected are presented in Table 24. Additional elements were detected, but the data on these elements were lost when the magnetic tape on which the data were stored was accidentally erased. With the exception of the material balance for iron, the remaining four elements balance as well as, or better than, the values obtained for mercury, lead, beryllium, and fluoride by direct chemical analysis.

Encouraged by the preliminary results, the remaining samples from the trace-element combustion experiments are being analyzed (including a reanalysis of the TRACE-3 samples) by this technique. Additional developmental work (see Appendix D) is also being done to gain the capability of detecting a larger number of elements and to improve the accuracy of the method. 
Table 23. Fluor-de Material Balances for Trace-Element Combustion Experiments

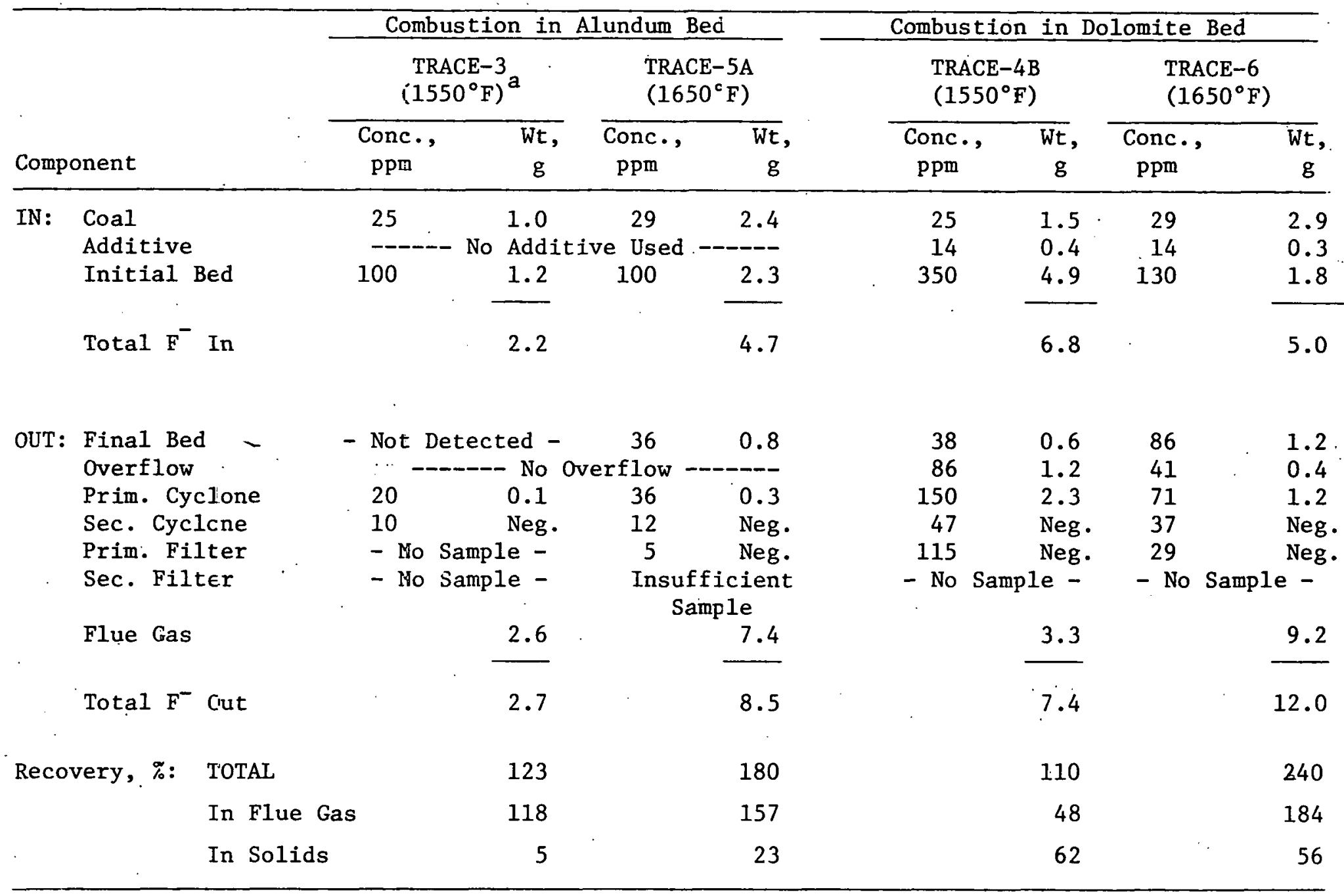

$a_{\text {Bed temperature. }}$ 
Table 24. Neutron Activation Results on Samples from the TRACE-3 Trace-Element Experiment

\begin{tabular}{|c|c|c|c|c|c|}
\hline \multirow[b]{2}{*}{ Element } & \multicolumn{3}{|c|}{ Concentration, ppm } & \multirow{2}{*}{\multicolumn{2}{|c|}{$\begin{array}{c}\text { Material Balance, } \\
\% \text { Recovery }\end{array}$}} \\
\hline & Coal & $\begin{array}{l}\text { Primary } \\
\text { Cyclone }\end{array}$ & $\begin{array}{l}\text { Secondary } \\
\text { Cyclone }\end{array}$ & & \\
\hline $\mathrm{Fe}$ & 11,300 & 33,000 & 39,000 & 3 & 7 \\
\hline $\mathrm{Cr}$ & - & 250 & 330 & - & - \\
\hline Sc & 2.4 & 18 & 23 & 9 & 6 \\
\hline $\mathrm{Na}$ & 960 & 11,000 & 10,000 & $14 ?$ & \\
\hline $\mathrm{K}$ & 460 & 2,800 & 2,800 & 7 & 6 \\
\hline$\angle n$ & 710 & 1,600 & -- & $\ldots$ & - \\
\hline $\mathrm{Cu}$ & 33 & 330 & 410 & 127 & 7 \\
\hline
\end{tabular}

Sodium Concentrations in Flue-Gas Particulates. Samples from several of the TRACE experiments have been analyzed for $\mathrm{Na}$ because of the considerable interest that has been expressed in $\mathrm{Na}$ as a source of corrosion in a combined-cycle power system, particularly corrosion of the blades of a high-temperature, gas turbine. The results of the analyses that have been completed thus far are presented in Table 25 . It would appear from the material balances that the $\mathrm{Na}$ is retained by the particulate matter during combustion. As with $\mathrm{Pb}$ and $\mathrm{Be}$, the concentration of $\mathrm{Na}$ in the particulate matter increases wit.h derreasing particle size. Concentrations generally vary from 0.5 wt \% for material removed in the primary cyclone to $1.5-2.0 \mathrm{wt} \%$ for material removed in the primary and secondary filters. It should be emphasized however, that the flue gas is cooled to approximately $600-800^{\circ} \mathrm{F}$ during the solids removal process. Because the flue gas entering the turbine w111 be at considerably higher temperatures $\left(\sim 1600^{\circ} \mathrm{F}\right)$, considerably less $\mathrm{Na}$ may be retained by the particulates during their removal at these higher temperatures.

Photomicrographs of Flue-Gas Particulates. Solid samples of Arkwright coal and fly ash recovered from the cyclones and Brink impactor at the conclusion of experiment TRACE-3 were examined under a scanning election microscope. Photomicrographs obtained for several of the samples are pictured in Fig. 25. Unlike the generally epherically shaped fly ash enitted from conventional coal-fired combustors, the photomicrographs depict the fly ash from the fluidizedbed combustor as a rather fragile and flake-like material. 
Table 25. Sodium Material Balances for Trace-Element Combustion Experiments

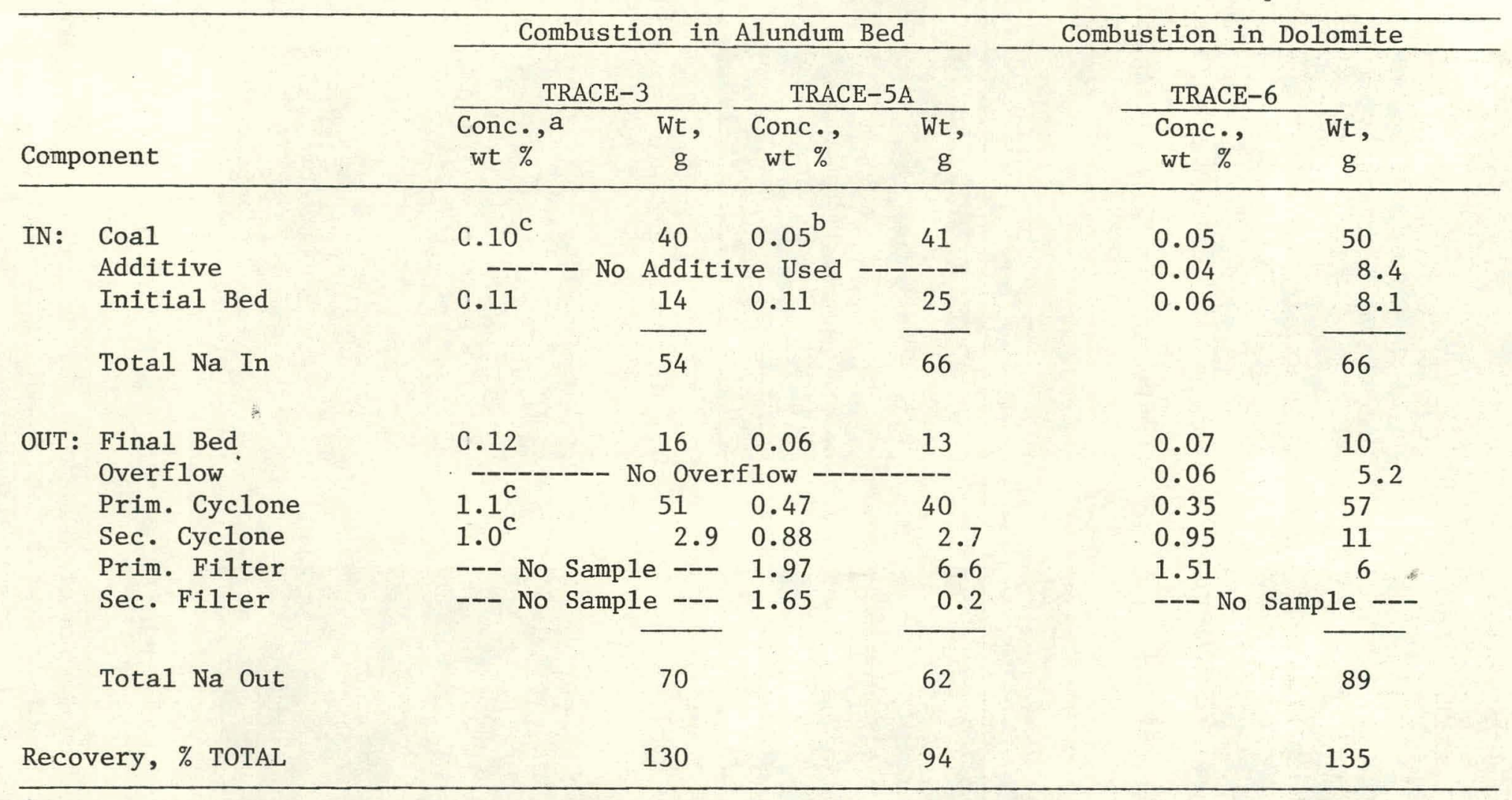

a Determined by atomic absorption spectroscopy.

${ }^{\mathrm{b}}$ Commercial Testing Company, Chicago, Illinois reported a value of 0.07 wt \% Na in Arkwright coal.

${ }^{c}$ Determined by neutron activation analysis. 


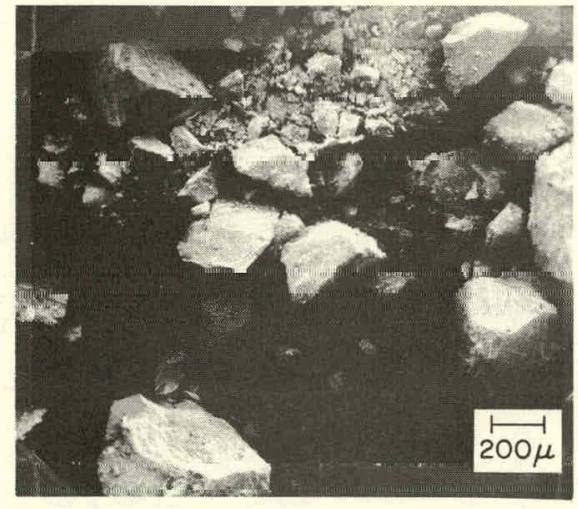

a. Arkwright Coal

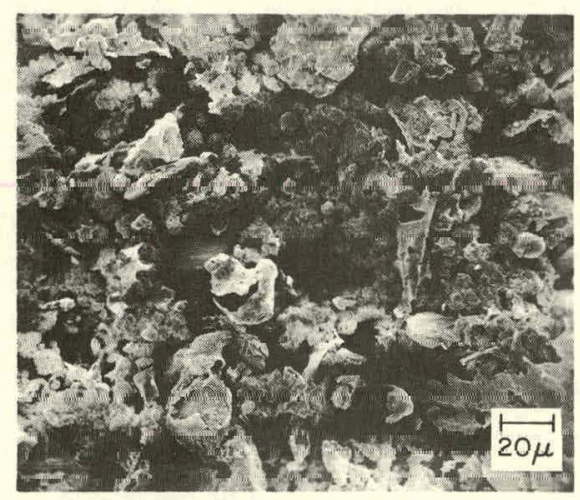

Secondary Cyc.lone Fly Ash

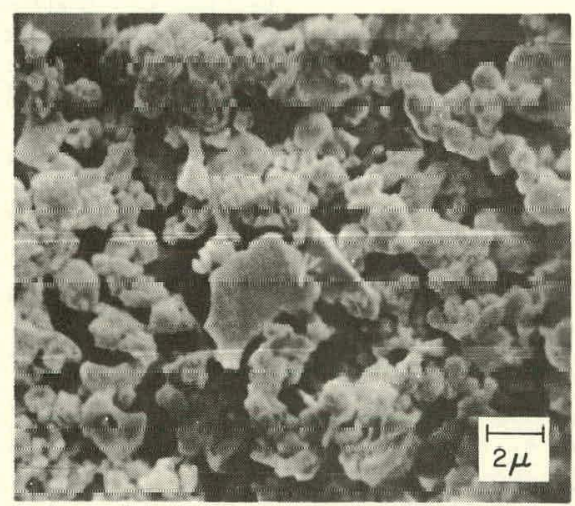

e. Brink Impactor Stage 3 Fly Ash

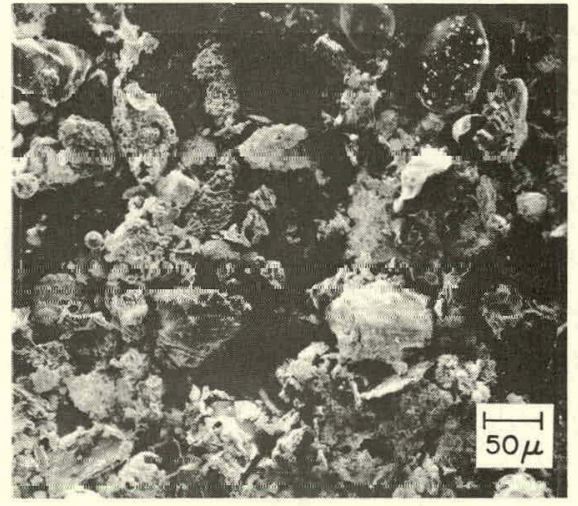

b. Primary Cyclone Fly Ash

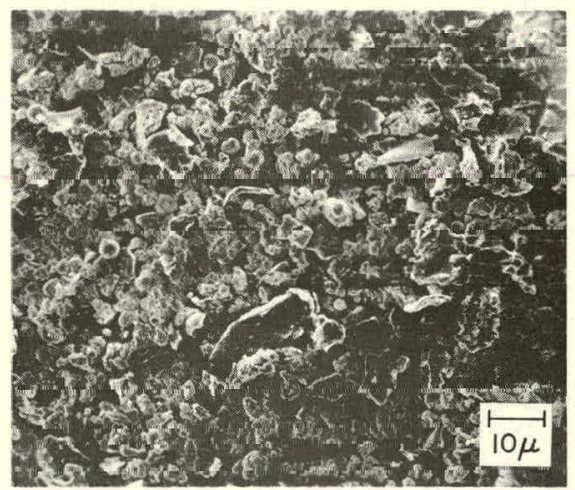

d. Brink. Impactor Stage 1 Fly Ash

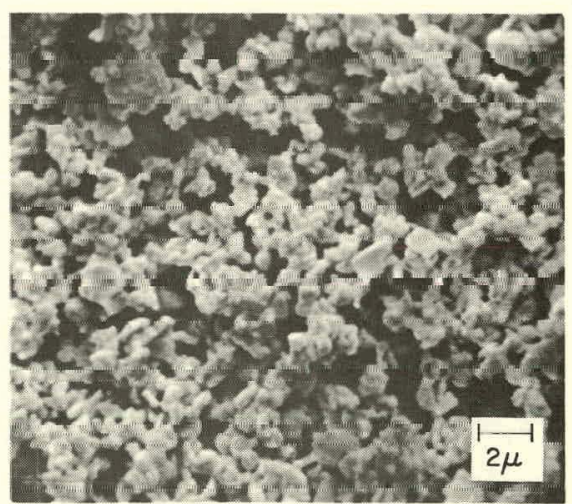
f. Brink Impactor
Stage 5 Fly Ash

Figure 25. Photomicrographs of Arkwright Coal and Fly Ash Recovered in Particulate Removal and Sampling Devices during Combustion Experiment TRACE-3 


\section{KINETICS OF THE REACTION OF HALF-CALCINED DOLOMITE WITH SULFUR DIOXIDE}

The kinetics of the reaction of half-calcined dolomite with sulfur dioxide is being studied to gain further insight into the sulfation process. Preliminary results of the study which is being carried out by a small basic chemistry support group, are presented below. Besides their application to the current fluidized-bed studies, it is hoped that these studies may also be of value in other processes for $\mathrm{SO}_{2}$ control, e.g. panel-bed filters.

The active material used in this program is half-calcined dolomite, which reacts with $\mathrm{SO}_{2}$ as indicated in $\mathrm{Eq}$. (8)

$$
\left[\mathrm{CaCO}_{3}+\mathrm{MgO}\right]+\mathrm{SO}_{2}+0.5 \mathrm{O}_{2} \rightarrow\left[\mathrm{CaSO}_{4}+\mathrm{MgO}\right]+\mathrm{CO}_{2}
$$

For economic and environmental reasons, it is desirable to regenerate the reactive material from the product by some scheme such as that indicated by Eqs. (9) and (10)

$$
\begin{gathered}
{\left[\mathrm{CaSO}_{4}+\mathrm{MgO}\right]+4 \mathrm{H}_{2} \rightarrow[\mathrm{CaS}+\mathrm{MgO}]+4 \cdot \mathrm{H}_{2} \mathrm{O}} \\
{\left[\mathrm{CaSO}_{4}+\mathrm{MgO}\right]+4 \mathrm{CO} \rightarrow[\mathrm{CaS}+\mathrm{MgO}]+4: \mathrm{CO}_{2}} \\
{[\mathrm{CaS}+\mathrm{MgO}]+\mathrm{H}_{2} \mathrm{O}+\mathrm{CO}_{2} \rightarrow\left[\mathrm{CaCO}_{3}+\mathrm{MgO}\right]+\mathrm{H}_{2} \mathrm{~S}}
\end{gathered}
$$

where the concentration of $\mathrm{H}_{2} \mathrm{~S}$ resulting from Eq. (10) is sufficiently high to permit sulfur recovery in a Claus plant.

A brief mention of some earlier work by others on this and other related systems seems approprtate. A considerable amount of work, including detailed kinetic studies, 15,16 has been reported on the reaction of calcined limestones with $\mathrm{SO}_{2}$ according to Eq. (11)

$$
\mathrm{CaO}+\mathrm{SO}_{2}+0.5 \mathrm{O}_{2}+\mathrm{CaSO}_{4}
$$

These studies were done in connection with both the fluidized-bed combustion and dry limeslone infection processes. The reactions of fully- and half-calcined limestones with $\mathrm{H}_{2} \mathrm{~S}$ [see Eqs. (12) and (13)]

$$
\begin{gathered}
{[\mathrm{CaO}+\mathrm{MgO}]+\mathrm{H}_{2} \mathrm{~S} \rightarrow[\mathrm{CaS}+\mathrm{MgO}]+\mathrm{H}_{2} \mathrm{O}} \\
{\left[\mathrm{CaCO}_{3}+\mathrm{MgO}\right]+\mathrm{H}_{2} \mathrm{~S} \rightarrow[\mathrm{CaS}+\mathrm{MgO}]+\mathrm{H}_{2} \mathrm{O}+\mathrm{CO}_{2}}
\end{gathered}
$$

have been studied in some detail in connection with other desulfurization schemes.16-20 Some results have also been reported on the reactions of interest $j \mathrm{n}$ work discussed here. $21-23$ Exploratory experiments on the application of the system considered here to panel-bed filtration have indicated its feasibility. ${ }^{23}$ Conclusions that can be drawn from this prior work include: 
(1) Dolomitic limestones (fully- or half-calcined) are more effective reagents than calcite and show considerable promise in sulfur emission control.

(2) The rate of the reduction reaction of the sulfation product to the sulfide [reaction (9)] appears to be satisfactory.

(3) The active reagent can be more readily regenerated [by reaction (10)] from sulfide produced by direct sulfidation with $\mathrm{H}_{2} \mathrm{~S}$ than from sulfide formed by reduction of the sulfated product resulting from reaction with $\mathrm{SO}_{2}$.

In the light of this prior work, the grals of nur program are (a) decermine the detailed kinetics of reactions (8), (9), and (10); (b) elucidate plausible mechanisms for these reactions; and (c) determine those conditions that optimize each of these reactions. Kinetic results for Eq. (8) at atmospheric pressure are presented here.

\section{Experimental}

Apparatus. The experimental apparatus is similar to that used by other workers $17,19,22$ and is schematically depicted in Fig. 26. The reactant gas mixture, which is prepared by controlling the flow of each constituent by means of a diaphragm-type regulator and calibrated rotameters; flows upward through the heated reaction tube, past the sample, and exits through a condenser and a series of scrubbers. Total flow can be controlled in the range from 200 to 400 $\mathrm{cc} / \mathrm{min}$ with an accuracy for the total flow and that of each constituent of about $\pm 2 \%$. The water content of the reactant gas is controlled by a thermostated humidifier. Sulfur dioxide is added to the stream after humidification. The sample is suspended from one arm of a recording balance and is contained in a platinum basket. The balance, which provides continuous weight data over the range from 0.2 to $1.0 \mathrm{~g}$ with an accuracy of $\pm 0.1 \mathrm{mg}$, is protected from corrosive gases by a purge flow of nitrogen. Temperature in the reaction zone is controlled by a Marshall furnace with an accuracy of $\pm 5^{\circ} \mathrm{C}$ up to about $950^{\circ} \mathrm{C}$ and is recorded along with sample weight on a recorder.

Materials. The apparatus is fabricated from glass and type 304 stainless steel. Commercial research-grade cylinder gases are used to make up the reactant gas stream. The stone used in these experiments was dolomite obtained from Charles Pfizer and Co., Gibsonburg, Ohio, and has an empirical formula $\mathrm{Ca}_{1.14} \mathrm{Mg} 0.86\left(\mathrm{CO}_{3}\right)_{2}$. Chemical analysis and petrographic characteristics of 1337 dolomite stone have been reported by Harvey. 24 


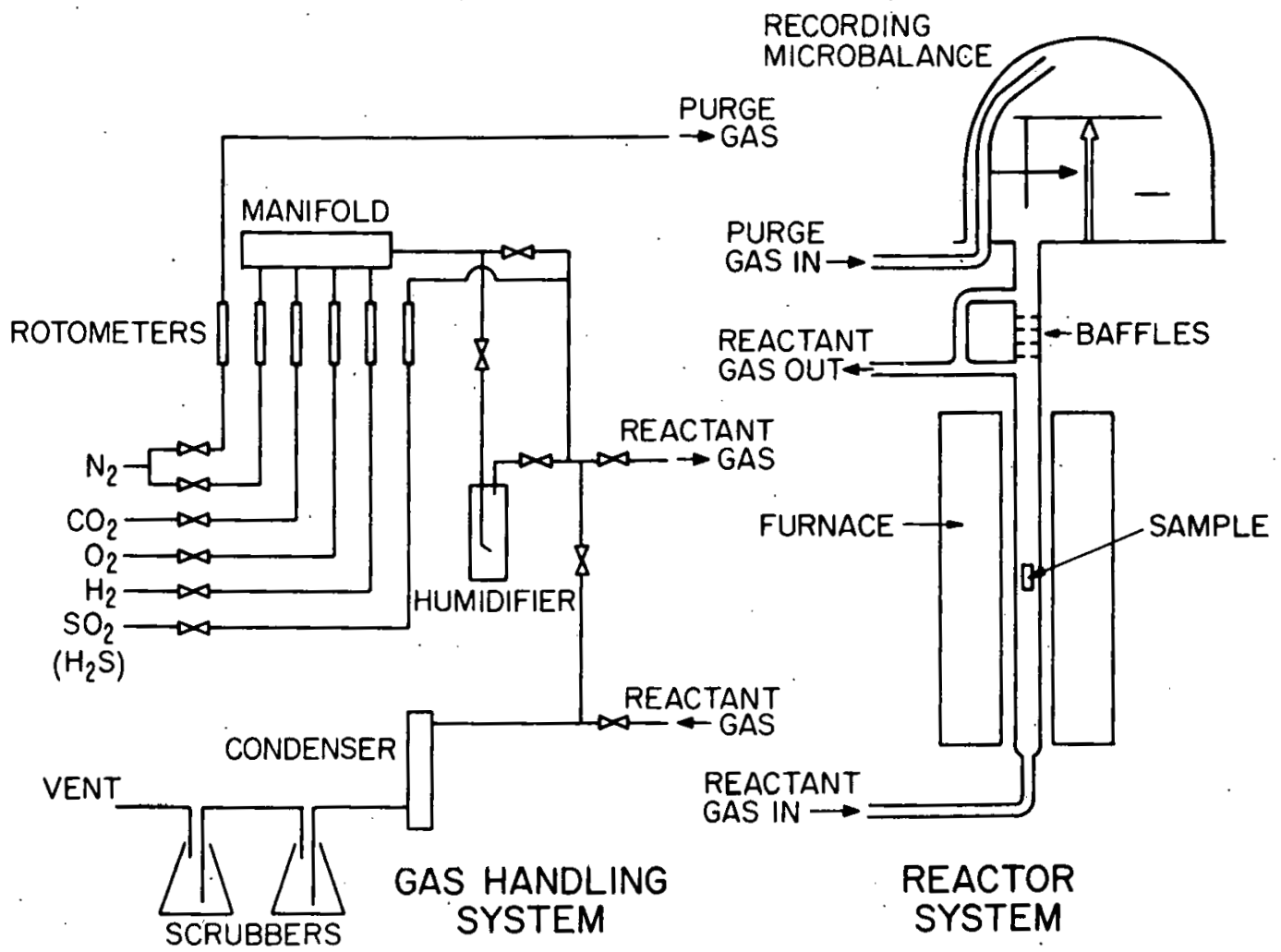

Figure 26. Schematic Diagram of the TGA Apparatus

Procedure. In a typical experiment, $200 \mathrm{mg}$ of 1337 dolomite particles having diameters in a narrow range around $1.1 \mathrm{~mm}(-16+18$ U.S. mesh, U.S. Sieve Series) are placed in the apparatus under a flow of $\mathrm{N}_{2}$ and $\mathrm{CO}_{2}$ and heated to $800^{\circ} \mathrm{C}$ at a rate of about $25^{\circ} / \mathrm{min}$ to halfcalcine the stone. Calcination is followed by observing the weight change of the sample. When half-calcination of the stone is complcte (usually after about $45 \mathrm{~min}$ ), sample temperature is adjusted to that selected for the experiment, the sample is isolated under the $\mathrm{N}_{2}$ and $\mathrm{CO}_{2}$ atmosphere, and the reactant gas mixture adjusted to the appropriate composition and flowrate for the experiment while bypassing the reaction tube. At time zero, the reactant gas is diverted through the reaction tube and the weight change of the sample observed as a function of time. The reaction is followed until the rate of weight change is negligible (typically about two hours for the experiments reported hexe).

To study the reaction of $\mathrm{MgO}$, a sample of reagent-grade $\mathrm{MgCO}_{3}$ was pressed into a dense pellet, which was then broken up to obtain a sample containing particles of the size used in the other experiments. Calcination and subsequent procedures were identical to those for other samples. 
The reaction rate, $r$, at any time during the reaction was calculated from the equation

$$
\mathbf{r}=\frac{1}{\mathrm{w}} \cdot \frac{\mathrm{dn}}{\mathrm{d} t}
$$

where $\mathrm{w}$ is the total weight of the sample after calcining, $\mathrm{n}$ is the amount of sulfate, as moles of $\mathrm{SO}_{3}$, reacted and $t$ is time in seconds.

Results and Discussion

Typical experimental results are shown in Fig. 27, where the fraction of the stone reacted [according to equation (8)] is plotted against time for several different $\mathrm{SO}_{2}$ concentrations. The reaction temperature and reactant-gas composition are given in the figure caption. It is evident that the reaction rate, and hence the extent of the reaction at a given time, is a function of $\mathrm{SO}_{2}$ concentration. f'igure 28 shows this same data in a plot of the $10 \mathrm{~g}$ of the initial reaction rate (initial. rates were actually evaluatcd at $t=1 \mathrm{~min}$, because of scatter in the data near $t=0$ ) versus the $\log \mathrm{SO}_{2}$ concentration. The straight line thus obtained has a slope of 1.08 and indicates that the reaction is first order with respect to $\mathrm{SO}_{2}$ concentration in the reactant gas under these reaction conditions. It should be noted that similar first-order dependence for the reaction of fully-calcined 1337 dolomite has been reported by Borgwardt 15 and, in fact, the reaction rates reported by Borgwardt are very similar to those observed here.

It was noticed in several early experiments that the concentration of water in the reactant gas appeared to influence the reaction rate. Results from a series of experiments in which the concentration of water in the reactant gas was varied while the concentration of other components was constant indicated, however, that. the reaction was essentlally zero order in water rnncentratinn. Another series if experiments in which the reactant gas was dry and the concentration of $\mathrm{SO}_{2}$ was varied gave the results shown in Fig. 29. Here the slope is 0.77 , indicating that the rate varies with roughly the threefourths root of $\mathrm{SO}_{2}$ concentration. Thus, it would appear that the ratedetermining step is different depending on whether or not water is present in the reactant gas. With water present, the reaction is 0.22 order with respect to oxygen concentration in the reactant gas stream.

The temperature dependence of the reaction rate with water present was examined over the range from 550 to $850^{\circ} \mathrm{C}$ (at higher temperatures, the concentration of $\mathrm{CO}_{2}$ necessary to prevent decomposition of $\mathrm{CaCO}_{3} 24$ could not be maintained with the present apparatus). The initial reaction rate increased significantly with temperature over this range. An Arrhenius plot of the data, shown in Fig. 30, indicates a linear dependence of rate on $1 / T$ and yields an apparent activation energy of $7.3 \mathrm{kcal} / \mathrm{mol}$. Such a value does not point conclusively to a mechanism in which some chemical reaction is rate controlling but is somewhat greater than one might expect if the reaction is diffusion controlled. 


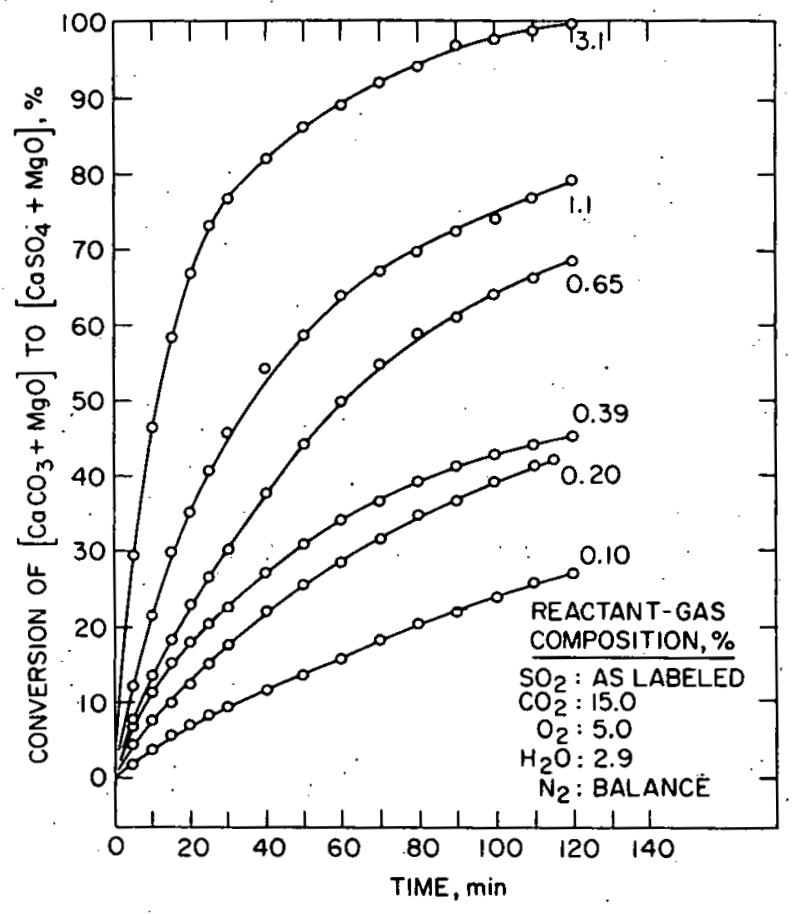

Figure 27. Percent Conversion vs. Time for Various $\mathrm{SO}_{2}$ Concentrations in the Reactant Gas at $750^{\circ} \mathrm{C}$

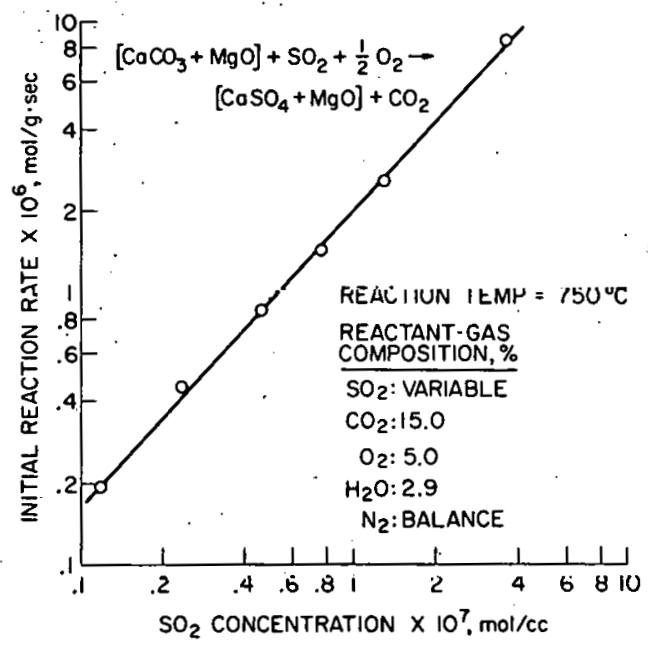

Figure 28. Initial Reaction Rate of $\mathrm{SO}_{2}$ with 1337 Dolomite as a Function of $\mathrm{SO}_{2}$ Concentration in the Presence of $\mathrm{H}_{2} \mathrm{O}$ 


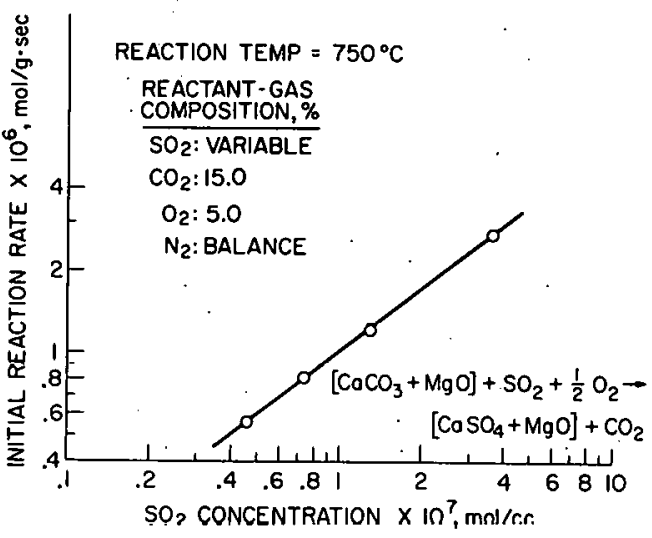

Figure 29. Initial Reacliún Rule of $\mathrm{SO}_{2}$ with 1337 inolonimite as a Funiclun of $\mathrm{SO}_{2}$ Concentration in the Absence of $\mathrm{H}_{2} \mathrm{O}$

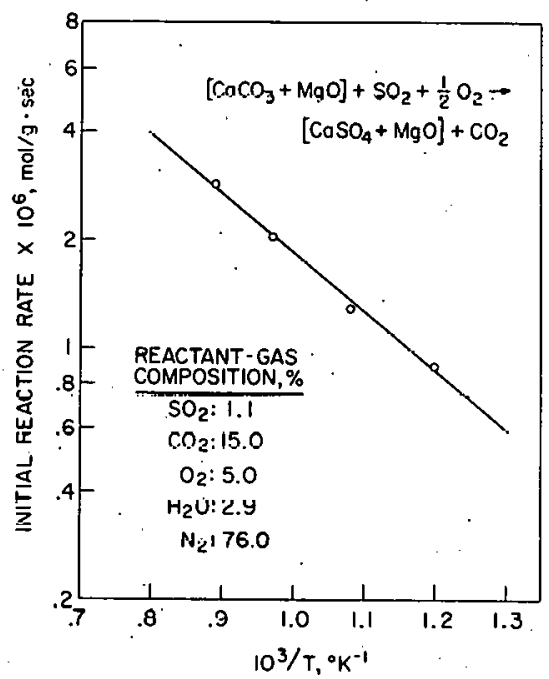

Figure 30. Arrhenius Plot for the Reaction of $\mathrm{SO}_{2}$ with Ilalf-Calicined 1337 Dolumlle

In some experimental runs, a greater than theoretical conversion cu sulface, based on Eq. (8) was observed. It has been reported that Mgn .undergoes sulfation; ${ }^{22}$ therefore, the eulfation of calcined $\mathrm{MgCO}_{3}$ was examined to assess the extent to which this reaction might interfere with detailed analysis of our results. Typical results are shown on Fig. 31, together with results for the half-calcined stone. The extent of sulfation of $\mathrm{MgO}$ is not great and the reaction rate is much less than that for the half-calcined stone; nevertheless, the effect is too great to be ignored in any more detailed treatment of the halfcalcined results. 


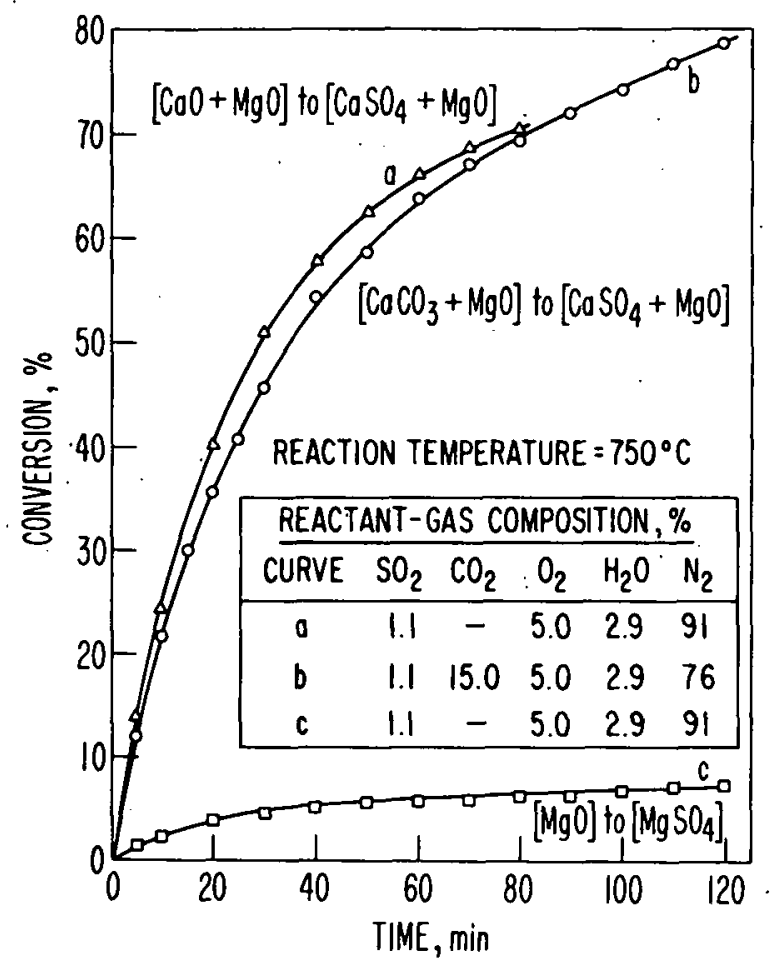

Figure 31. Percent Sulfation vs. Time

for a) $[\mathrm{CaO}+\mathrm{MgO}]$; b) $\left[\mathrm{CaCO}_{3}+\mathrm{MgO}\right]$; and c) $\mathrm{MgO}$ at $750^{\circ} \mathrm{C}$

Figure 31 also shows results obtained for the sulfation of fullycalcined stone reacted under the same conditions as half-calcined except that $\mathrm{CO}_{2}$ was absent in the reactant gas. The results for the half-calcined and fully-calcined dolomite are very similar as one might expect in view of the generally close correlation between our work and that of Borgwardt. 15

To date, several attempts to fit our results 'with a simple kinetic model such as that based on a shrinking unreacted core or on reaction of a porous solid have not been satisfactory. A possible explanation for the apparent role of water in the mechanism might be that the $\mathrm{SO}_{2}$ is oxidized by the water to $\mathrm{SO}_{3}$ on the surface of the reactant stone, followed by $\mathrm{SO}_{3}$ diffusing through a product layer to the unreacted core of the solid for reaction with $\mathrm{CaCO}_{3}$. This concept would he consistent with the simjlar kinetics observed for half- and fully-calcined stone since the rate-determining step would presumably be the same in either case. This view is supported by the observation that reactivity in a fluidized bed drops off somewhat above about $850^{\circ} \mathrm{C}$, where the thermodynamics of $\mathrm{SO}_{2}$ oxidation become less favorable. On the other hand, Borgwardt's observations with fully-calcined stone 14 suggest that the decreased reactivity is due to hard-burning of the stone. 
Further work is needed to understand more fully the role of water in the sulfation mechanism and to extend the kinetic studies to the reduction and regeneration reactions outlined above. The potential advantages of a process utilizing dolomite in a closed cycle for $\mathrm{SO}_{2}$ control are sufficiently great to warrant continued effort. 


\section{ACKNOWLEDGMENTS}

We gratefully acknowledge the help given by Mr. L. Burris, Mr. D. S. Webster, Dr. S. Lawrosk1, and Mr. L. Link in directing and reviewing the program.

We are Indebted to $C$. Schoffstoll and J. Stockbar for their technical assistance in the operation and maintenance of the benchscale fluidized-bed combustor.

We would also like to express appreciation to Mr. E. Kucera, Mr. M. Homa, Mrs. Florence Willlams, Mrs. Jackie Williams, Mr. R. Telford, and $M r$. K. Jensen for general analytical services, to $M r$. R. Bane for trace-element analyses, to Mr. R. Helnrich for neutron activation analyses; and to $\mathrm{Mr}$. J. Faris for spectrochemical analyses. 


\section{REFERENCES}

1. A. A. Jonke et al., Reduction of Atmospheric Pollution by the Application of Fluidized-Bed Combustion, Annual Report, July 1971-June 1972, ANL/ES/CEN-1004 (1972).

2. G. A. Hammons and A. Skopp, A Regenerative Limestone Process for Fluidized-Bed Coal Combustion and Desulfurization, Final report prepared under contract No. CPA-70-19 for.Process Control Engineering Program, Air Pollution Control office: Esso Research and Engineering Company, Government Research Laboratory, Linden New Jersey (Feb. 28, 1971).

3. A. Skopp, M. S: Nutkis, G. A. Hammons, and R. R. Bertrand, Studies of the Fluidized Lime-Bed Coal Combustion Desulfurization System, Final report prepared under contract No. CFA-70-19 Lur the Control Systame Division, Office of Alr Programs, U. S. Environmental Protection Agency: Esso Research and Engineering Company, Government Research Laboratory, Linden, New Jersey (Dec. 31, 1971).

4. Proceedings of Third International Conference on Fluidized-Bed Combustion, U. S. Environmental Protection Agency Report, EPA-650/2-73-053 (December 1973).

5. S. Ehrlich, E. B. Robison, J. S. Gordon, and J. W. Bishop, Development of a Fluidized-Bed Boiler, AIChE Symposium Series No. 126, Vol. 68 (1972).

6. D. Kunii and 0. Levenspie1, Fluidization Engineering, Johu Wiley and Sons, Inc., New York, N. Y., 76-80 (1969).

7. E. L. Carls, Review of British Program on Fluidized-Bed Combustiun; Report of U. S. Team Visit to England, February 17-28, 1969, Argonne National Laboratory Report, ANL/ES/CEN-1000 (1969).

8. R. M. Statnik, D. K. Oestreich, and R. Steiber, Sampling and Aralysis of Mercury Vapor in Industrial Streams Contalning Sulfur Dioxide, Preprint of paper presented at the 1973 American Chemical Society Annual Meeting, August. 26-31, 1973.

9. C. E. Billings, A. M. Sacco, W. R. Matson, R. M. Griffin, W. R. Conlglio, and K. A. Har'ley, Mercury Balance on a Large Pulverized Coal-Fired Furnace, Preprint of paper presented at the 65th Annual Meeting of the Air Pollution Control Assoctation, June 18-22, 1972.

10. R. C. Dieh1, É. A. Hattman, H. Schultz, and R. J. Haren, Fate of Trace Mercury in the Combustion of Coal, Bureau of Mines Managing Coal Wastes and Pollution Program, Technical Progress Report No. 54 (1972). 
11. R. E. Lee, Jr., S. S. Goranson, R. E. Enrione, and G. B. Morgan, National Air Surveillance Cascade Impactor Network II. Size Distribution Measurements of Trace Metal Components, Environ. Sci. and Techno1. 6 , 1025 (1972).

12. M. Kertesz-Saringer, E. Meszaros, and T. Varkoni, Atmospheric Environment $\underline{5}, 429$ (1971).

13. D. F. S. Natusch, J. R. Wallace, and C. A. Evans, Jr., Toxic Trace Elements: Preferential Concentration in Respirable Particles, Science 183; 202 (Jan. 18, 1974).

14. R. R. Ruch, H. J. Gluskoter, and N. F. Shimp, Occurrence and Distribution of Potentially Volatile Trace Elements in Coal, Illinois State Geological Survey, Environmental Geology Notes No. 61 (1973).

15. R. H. Borgwardt, Environ. Sci. and Technol. 4, 59 (1970).

16: E. P. 'O'Neil1, D. L. Keairns, and W. F. Kettle, Paper presented at 3rd International Conference on Fluidized-Bed Combustion, Hueston Woods, Ohio, Oct. 29-Nov. 1, 1972.

17. M. Pell, Ph.D. Thesis, City University of New York (1970).

18. M. Pe11, R. A. Graff, and A. M. Squires, Sulfur and $\mathrm{SO}_{2}$ Developments, AIChE (1971).

19. A. M. Squires, R. A. Graff, and M. Pell, Chemical Engineering Progress Symposium Series 67, pp. 23-24 (1971).

20. L. A. Ruth, A. M. Squires, and R. A. Graff, Environ. Sci. and Techno1. 6:12, 1009 (1972).

21. R. R. Bertrand, A. C. Frost, and A. Skopp, Fluid Bed Studies of the Limestone Based Flue Gas Desulfurization Process, Interim Report; Contract No. PH 86-67-103, for National Air Pollution Control Admin., Esso Research and Engineering Company, Linden, N. J. (1968).

22. S. G. Narayanan, M.S. Thesis, City University of New York (1971).

23. A. M. Squires and R. A. Graff, Paper presented at 63 rd Annual Meeting of the Air Pollution Control Association, St. Louis, Mo., June 14-18, 1970.

24. R. D. Harvey, Petrographic and Mineralogical Characteristics of Carbonate Rocks Related to Sulfur Dioxide Sorption in Flue Gases Final report, contract No. CPA 22-69-6.5 for U.S. Environmental Protection Agency, Illinois State Geological Survey, Urbana, Illinois (July 15, 1971). 
25. K. J. Hil1 and E. R. S. Winter, J. Phys. Chem. 60, 1361 (1956).

26. A. A. Jonke et al., Reduction of Atmospheric Pollution by the Application of Fluidized-Bed Combustion and Regeneration of SulfurContaining Additives, Annual Report, July 1972-June 1973, ANL/ES-CEN-1006 (in press). 
APPENDIX A. CHARACTERISTICS OF RAW MATERIALS

USED IN FLUIDIZED-BED COMBUSTION EXPERIMENTS 
Table A-1. Particle-Size Distribution and Chemical

Characteristics of Arkwright Coal

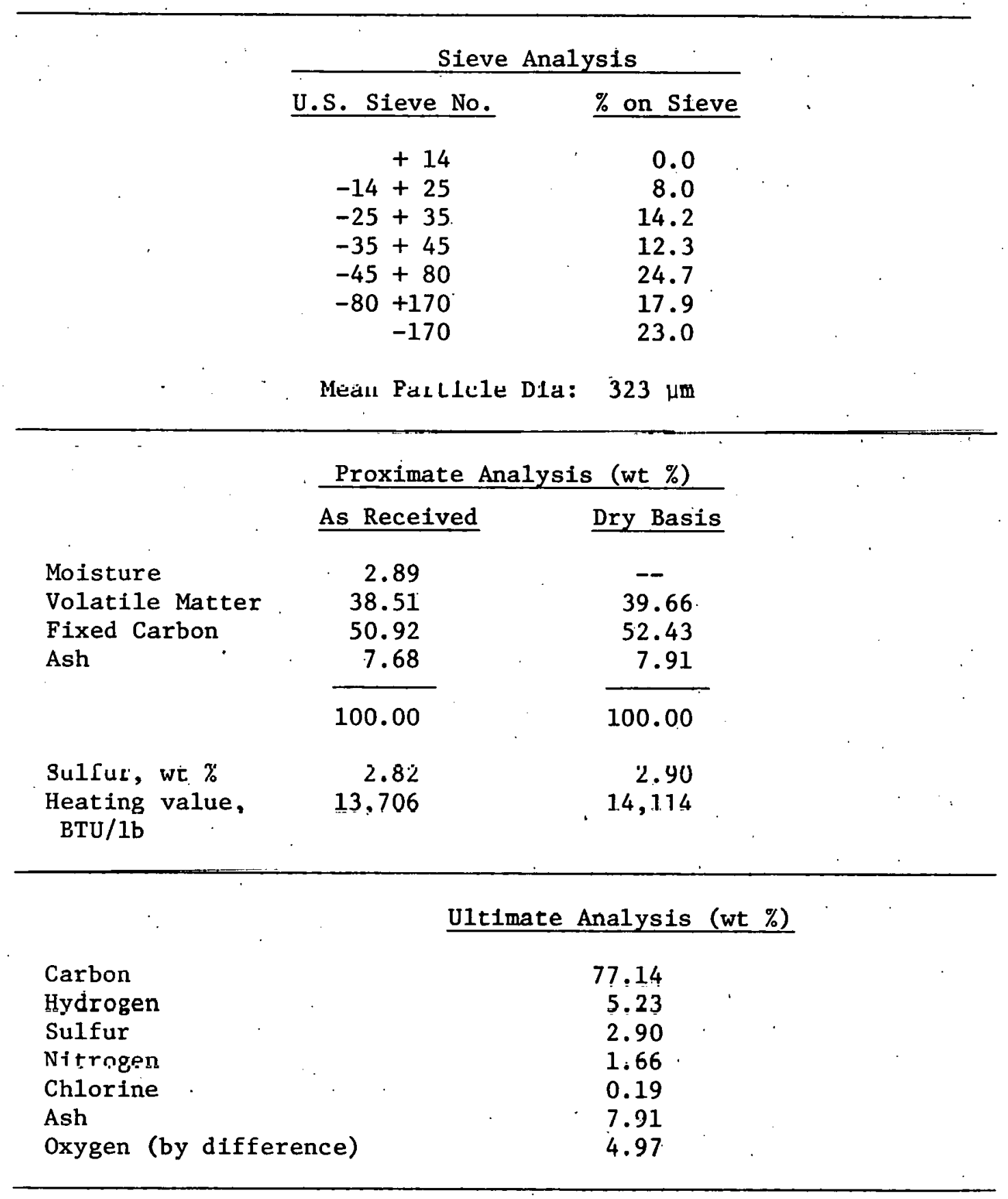


Table A-2. Particle-Size Distribution and Chemical

Characteristics of San Juan Subbituminous Coal

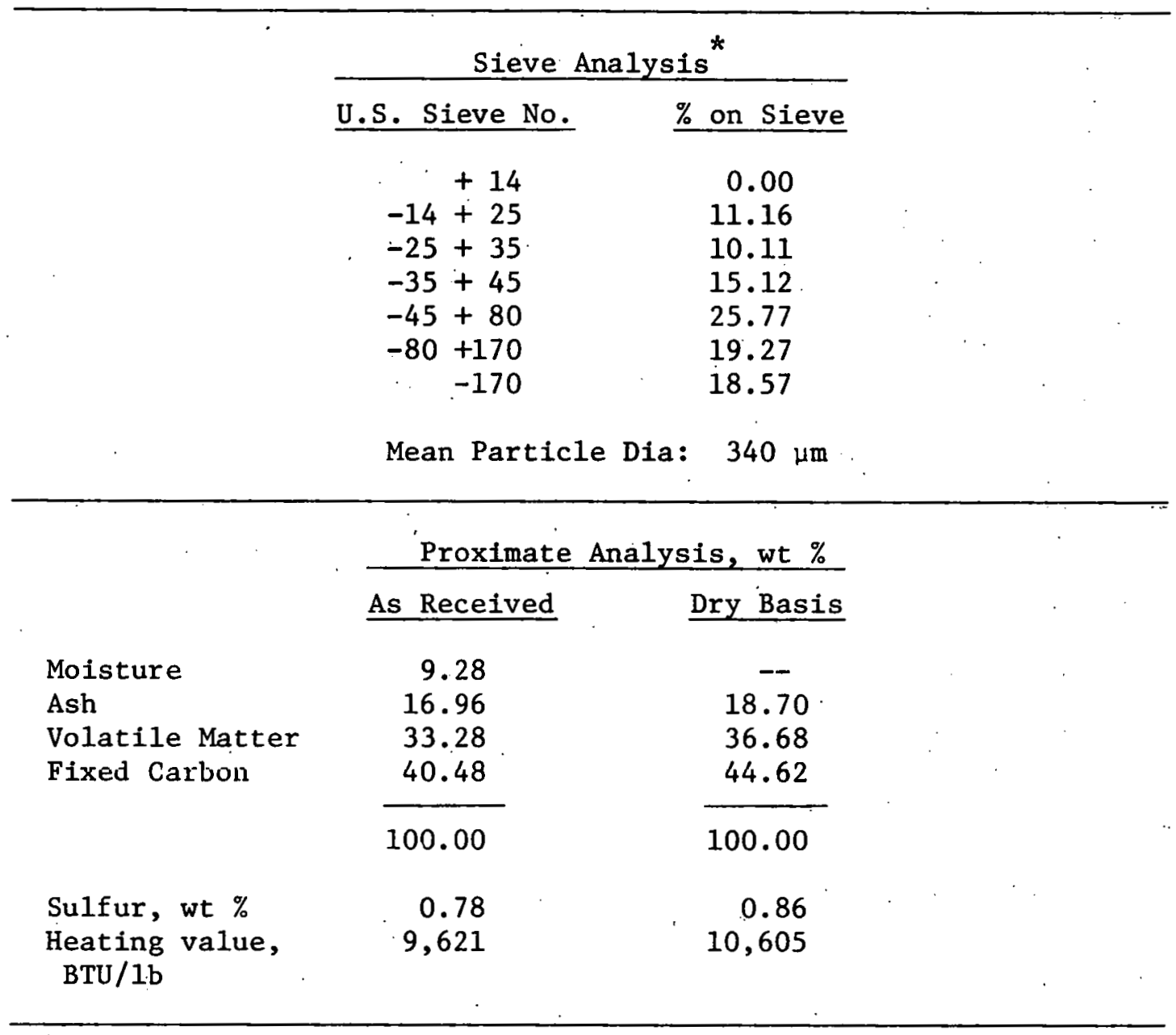

U1timate Analysis, wt \%

As Received Dry Basis

\begin{tabular}{lrr} 
Moisture & 9.28 & -- \\
Carbon & 55.82 & 61.53 \\
Hydrogen. & 3.96 & 4.36 \\
Nitrogen & 1.14 & 1.26 \\
Chlorine & 0.10 & 0.11 \\
Sulfur & 0.78 & 0.86 \\
Ash & 16.96 & 18.70 \\
Oxygen $\quad$ (by difference) & 11.96 & 13.18 \\
\cline { 2 - 3 } & 100.00 & 100.00
\end{tabular}

*Average of two samples, as received. 
Table A-3. Particle-Size Distribution and Chemical Characteristics of Glenharold Lignite

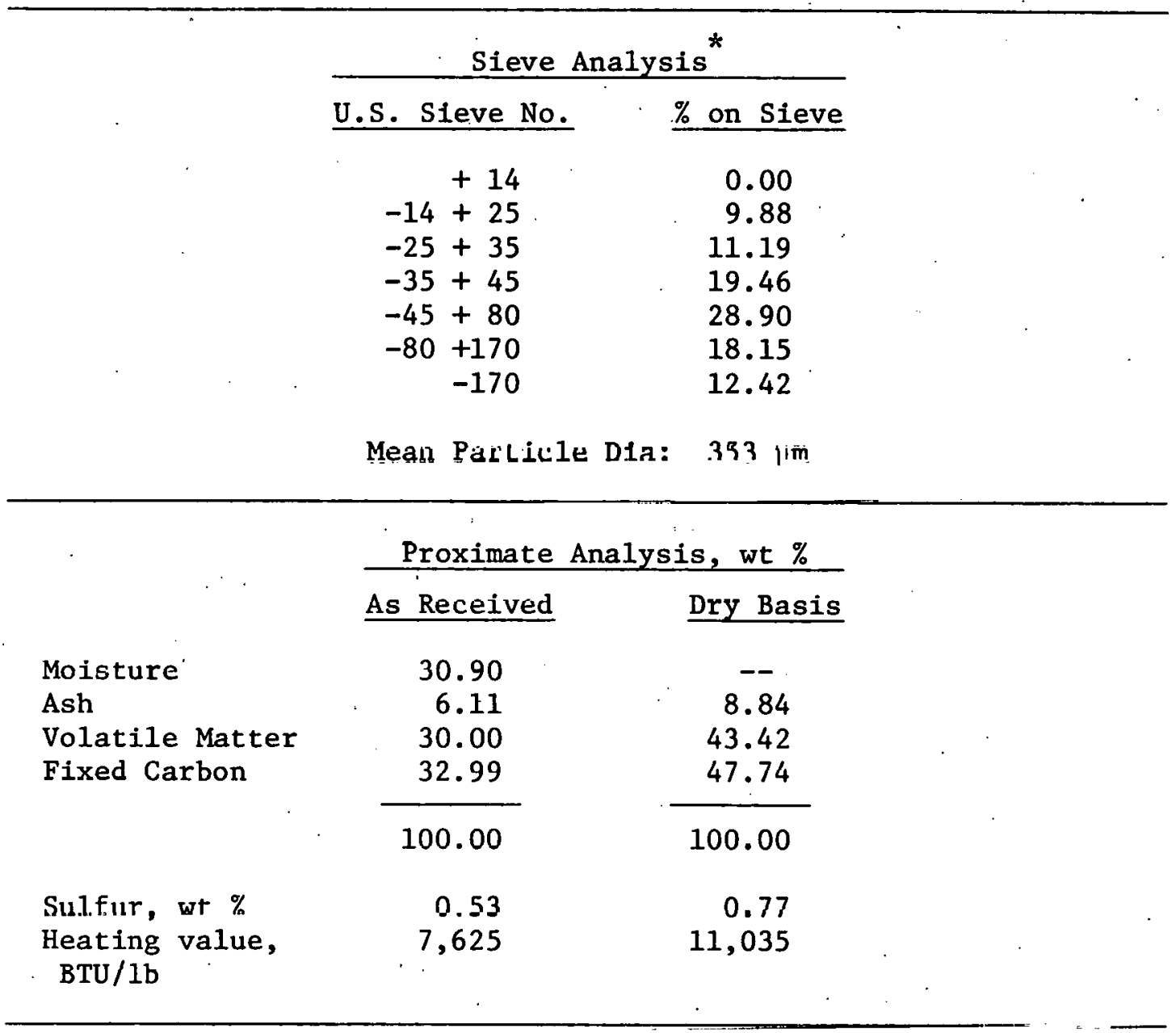

\begin{tabular}{lcr} 
& \multicolumn{2}{c}{ U1timate Analysis, wt \% } \\
\cline { 2 - 3 } & As Received & Dry Basis \\
\cline { 2 - 3 } Mnisture & 30.90 & \\
Carbon & 46.04 & 66.63 \\
Hydrogen & 3.03 & 4.38 \\
Nitrogen & 0.72 & 1.04 \\
Chlorine & 0.04 & 0.06 \\
Sulfur & 0.53 & 0.77 \\
Ash & 6.1 .1 & 8.84 \\
Oxygen & 12.63 & 18.28 \\
(by difference) & 100.00 & 100.00 \\
& & \\
\hline Average of two samples, as received.
\end{tabular}


Table A-4: Particle-Size Distribution and Chemical Characteristics of Tymochtee Dolomite

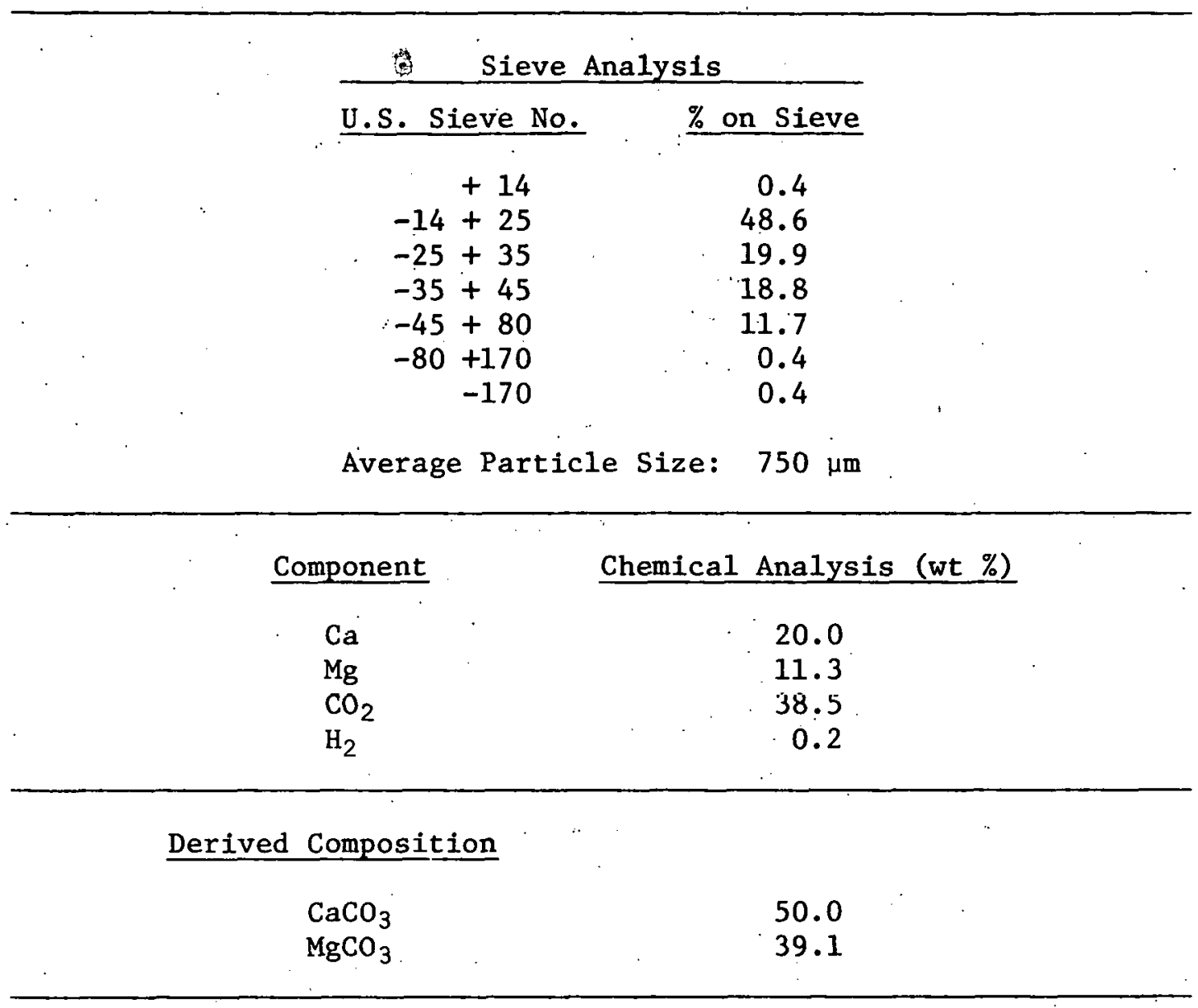


Table A-5. Particle-Size Distribution and Chemical Characteristics of Type-38 Alundum Grain Obtained from the Norton Company

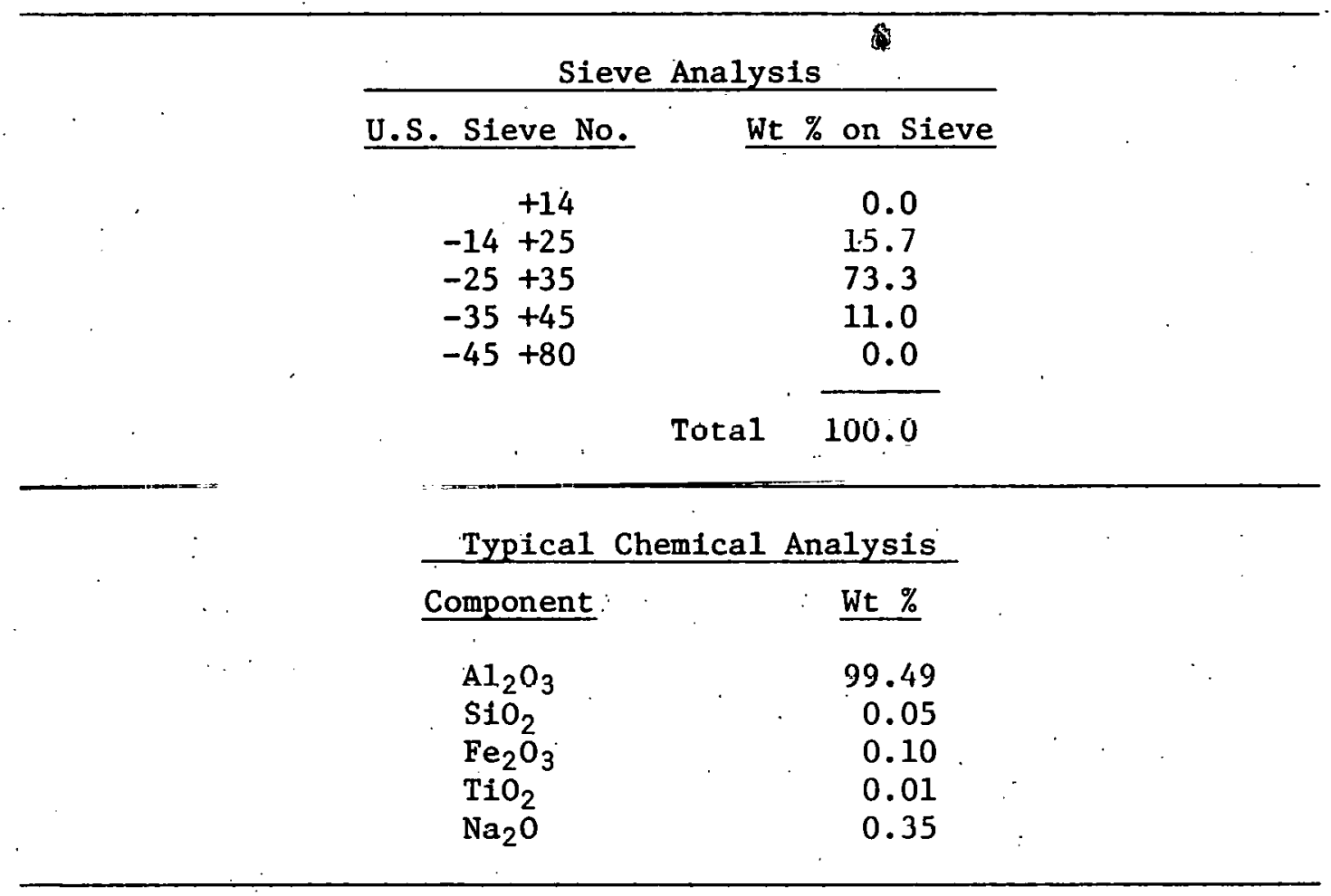


APPENDIX B. CARBON, SULFUR, AND CALCIUM MATERIAL BALANCES

FOR COMBUSTION EXPERIMENTS 
Tatle B-1. Carbon, Sulfur, and Calcium Material Balances cor VAR-1 Experiment

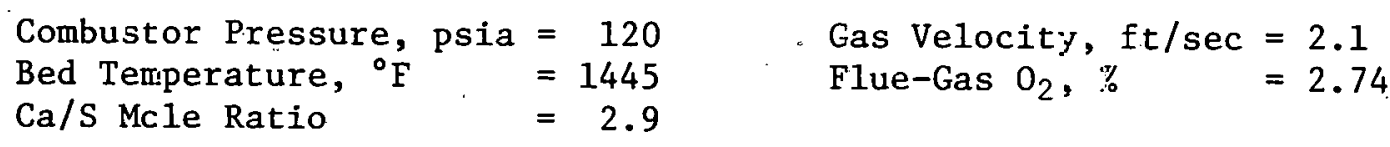

\begin{tabular}{ccccccc}
\hline Source of Material & $\begin{array}{c}\text { Weight, } \\
\mathrm{g}\end{array}$ & $\begin{array}{c}\text { Carbon, } \\
\text { wt } \%\end{array}$ & $\begin{array}{c}\text { Carbon, } \\
\mathrm{g}\end{array}$ & $\begin{array}{c}\text { Sulfur, } \\
\text { wt } \%\end{array}$ & $\begin{array}{c}\text { Sulfur, } \\
\mathrm{g}\end{array}$ & $\begin{array}{c}\text { Calcium, } \\
\text { wt } \%\end{array}$ \\
\hline
\end{tabular}

\section{Material in}

Starting bet ${ }^{a}$

Arkwright coal

Dolomite additive

14,000
39,917
19,958

1.9
74.91

10.5

$\begin{array}{r}266 \\ 29,902 \\ 2,096 \\ \hline 32,264\end{array}$

\begin{tabular}{lr}
10.9 & 1,526 \\
2.82 & 1.126 \\
0.3 & 60 \\
\cline { 2 - 2 } & 2,712
\end{tabular}

3.8

15,730

16,264

Bed overflow

Primary cyclone

Secondary cyclone

Secondary filter

Flue gas $b$

$$
4,998
$$

454

278

$-$

\begin{tabular}{rr}
3.8 & 598 \\
4.4 & 716 \\
51.4 & 2,569 \\
30.8 & 140 \\
10.0 & 28 \\
-- & $3,324^{c}$ \\
\hline & 37,375
\end{tabular}

7.0
5.8
1.0
1.8
3.4

116

$\%$ Balance

\begin{tabular}{cr}
23.9 & 3,346 \\
0.44 & 176 \\
20.0 & 3,992 \\
\hline & 7,514
\end{tabular}

23.5

25.1

3.58

4.2

4.4

--

$$
\begin{array}{r}
3,697 \\
4,082 \\
179 \\
19 \\
12 \\
-- \\
\hline 7,989 \\
106
\end{array}
$$$$
80
$$

${ }^{\text {a Partially sulfated dolomite. }}$

${ }^{b}$ Avg. flue-gas flowrate (dry basis), $\operatorname{cfm}$ at $70^{\circ} \mathrm{F}$ and 1 atm $=47.5$.

${ }^{\mathrm{C}}$ Calculated for avg. $\mathrm{CO}$ conc. of 98 ppm flus avg. $\mathrm{CO}_{2}$ conc. of $172,000 \mathrm{ppm}$.

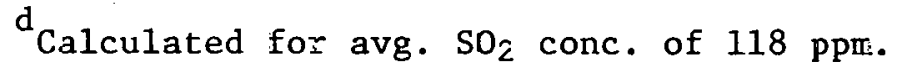


Table B-2. Carbon, Sulfur, and Calcium Material Balances for VAR-2 Experiment

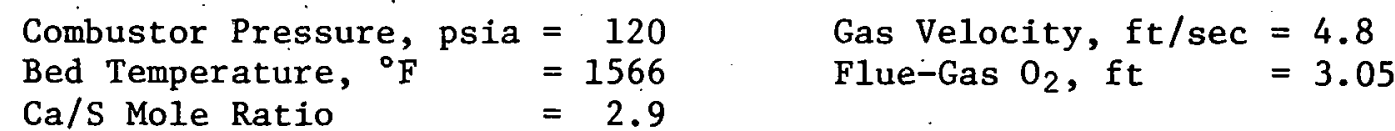

$\mathrm{Ca} / \mathrm{S}$ Mole Ratio

$\begin{aligned} \text { Gas Velocity, } \mathrm{ft} / \mathrm{sec} & =4.8 \\ \text { Flue-Gas } & =3.05\end{aligned}$

\begin{tabular}{|c|c|c|c|c|c|c|c|}
\hline Source of Material & $\begin{array}{l}\text { Weight, } \\
\mathrm{g}\end{array}$ & $\begin{array}{c}\text { Carbon, } \\
\text { wt } \%\end{array}$ & $\begin{array}{c}\text { Carbon, } \\
\mathrm{g}\end{array}$ & $\begin{array}{l}\text { Sulfur, } \\
\text { wt } \%\end{array}$ & $\begin{array}{l}\text { Sulfur, } \\
\mathrm{g}\end{array}$ & $\begin{array}{l}\text { Calcium, } \\
\text { wt \% }\end{array}$ & $\begin{array}{c}\text { Calcium } \\
\mathrm{g}\end{array}$ \\
\hline \multicolumn{8}{|l|}{ Material in } \\
\hline $\begin{array}{l}\text { Starting bed }{ }^{a} \\
\text { Arkwright coal } \\
\text { Dolomite additive }\end{array}$ & $\begin{array}{l}11,353 \\
63,731 \\
34,474\end{array}$ & $\begin{array}{l}1.8 \\
74.91 \\
10.5\end{array}$ & $\begin{array}{r}204 \\
47,741 \\
3,520 \\
\end{array}$ & $\begin{array}{l}8.8 \\
2.82 \\
0.3\end{array}$ & $\begin{array}{r}999 \\
1,797 \\
103 \\
\end{array}$ & $\begin{array}{c}22.1 \\
0.44 \\
20.0\end{array}$ & $\begin{array}{r}2,509 \\
280 \\
6,895\end{array}$ \\
\hline & : & & 51,565 & & 2,899 & & 9,684 \\
\hline Material out & & & & & & & \\
\hline $\begin{array}{l}\text { Final bed } \\
\text { Bed overflow } \\
\text { Primary ayclone } \\
\text { Secondary cyclone } \\
\text { Secondary filter } \\
\text { Flue gas }\end{array}$ & $\begin{array}{r}15,000 \\
3,018 \\
32,391 \\
787 \\
961 \\
--\end{array}$ & $\begin{array}{r}4.2 \\
3.7 \\
-\quad 11.1 \\
11.7 \\
4.7 \\
--\end{array}$ & $\begin{array}{r}530 \\
112 \\
3,595 \\
92 \\
45 \\
54,109^{c}\end{array}$ & $\begin{array}{l}6.3 \\
6.5 \\
4.5 \\
3.6 \\
4.2 \\
--\end{array}$ & $\begin{array}{r}945 \\
196 \\
1,458 \\
28 \\
40 \\
107\end{array}$ & $\begin{array}{r}23.1 \\
23.3 \\
18.7 \\
9.3 \\
10.4 \\
--\end{array}$ & $\begin{array}{r}3,465 \\
703 \\
6,057 \\
73 \\
100 \\
--\end{array}$ \\
\hline & & & 58,583 & . & 2,774 & & 10,398 \\
\hline$\%$ Balance & & & 114 & & 96 & & 107 \\
\hline
\end{tabular}

${ }^{a}$ Partially sulfated dolomite.

${ }^{b}$ Avg. flue-gas flowrate (dry basis), cfm at $70^{\circ} \mathrm{F}$ and 1 atm $=102.9$.

${ }^{c}$ Calculated for avg. $\mathrm{CO}$ conc. of $31 \mathrm{ppm}$ plus avg. $\mathrm{CO}_{2}$ conc. of 174,000 ppm.

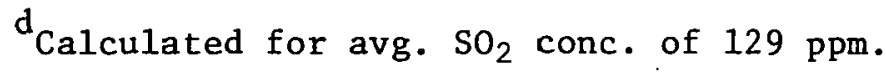


Table B-3. Carbon, Sulfur, and Calcium Material Balances for VAR-3 Experiment

Combustor Pressure, psia $=120$

Bed Temperature, ${ }^{\circ} \mathrm{F}=1574$ Ca/s Nole Ratio
Gas Velocity: $\mathrm{ft} / \mathrm{sec}=2.1$

Flue-Gas $\mathrm{O}_{2}, \%=2.95$

\begin{tabular}{|c|c|c|c|c|c|c|c|c|}
\hline Source of Material & $\begin{array}{l}\text { Weight, } \\
\mathrm{g}\end{array}$ & $\begin{array}{c}\text { Carbon, } \\
\text { wt \% }\end{array}$ & $\begin{array}{c}\text { Carbon, } \\
\cdot \mathrm{g}\end{array}$ & $\begin{array}{c}\text { Sulfưr, } \\
\text { wt } \%\end{array}$ & & $\begin{array}{c}\text { SulEur, } \\
g\end{array}$ & $\begin{array}{c}\text { Calcium, } \\
\text { wt } \%\end{array}$ & $\begin{array}{c}\text { Calcium } \\
\mathrm{g}\end{array}$ \\
\hline \multicolumn{9}{|l|}{ Material in } \\
\hline \multirow[t]{2}{*}{$\begin{array}{l}\text { Starting bed } \\
\text { Arkwrigh coal } \\
\text { Dolomite additive }\end{array}$} & \multirow[t]{2}{*}{$\begin{array}{r}12,603 \\
187,790 \\
34,927\end{array}$} & \multirow[t]{2}{*}{$\begin{array}{l}2.4 \\
74.91 \\
10.5\end{array}$} & $\begin{array}{r}302 \\
140,673 \\
3,667\end{array}$ & \multicolumn{2}{|l|}{$\begin{array}{l}8.5 \\
2.82 \\
0.3\end{array}$} & $\begin{array}{r}1,071 \\
5,296 \\
105\end{array}$ & \multirow[t]{2}{*}{$\begin{array}{l}21.4 \\
0.44 \\
20.0\end{array}$} & $\begin{array}{r}2,697 \\
826 \\
6,985\end{array}$ \\
\hline & & & 144,642 & & & 6,472 & & 10,508 \\
\hline \multicolumn{9}{|l|}{ Material out } \\
\hline Final bed & \multirow{6}{*}{$\begin{array}{r}9,978 \\
30,997 \\
15,714 \\
1,742 \\
1,254 \\
--\end{array}$} & 1.04 & 104 & 12.2 & & 1.217 & 19.7 & 1,966 \\
\hline \multirow{5}{*}{$\begin{array}{l}\text { Bed overflow } \\
\text { Primary cyclone } \\
\text { Secondary cyclone } \\
\text { Secondary filter } \\
\text { Flue gas } b\end{array}$} & & 1.7 & 527 & 10.2 & & $3,-62$ & 20.1 & 6,230 \\
\hline & & 31.1 & 4,887 & 2.0 & & 314 & 4.5 & 707 \\
\hline & & 21.0 & 366 & 2.0 & & 35 & 3.8 & 66 \\
\hline & & -- & $143,621^{c}$ & $-\infty$ & . & . $914^{\mathrm{d}}$ & -- & -- \\
\hline & & & 149,581 & & & 5,680 & & 9,029 \\
\hline$\%$ Balance & & & 103 & $\therefore$ & & 88 & & 86 \\
\hline
\end{tabular}

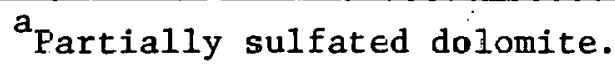

${ }^{\mathrm{b}}$ Avg. flue-gas flowrate (dry basis), cfm at $70^{\circ} \mathrm{F}$ and 1 atm $=46.0$.

${ }^{c}$ Calculated for avg. Co conc. of 31 ppm plus avg. $\mathrm{CO}_{2}$ conc. oI 147,000 ppm.

${ }^{\mathrm{d}}$ Calculated for avg. $\mathrm{SO}_{2}$ conc. of $351 \mathrm{ppm}$.
} 
Table B-4. Carbon, Sulfur, and Calcium Material Balances for VAR-4 Experiment

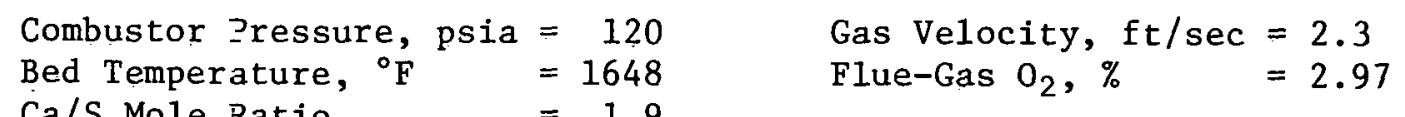

$\mathrm{Ca} / \mathrm{S}$ Mole Ratio $\quad=1.9$

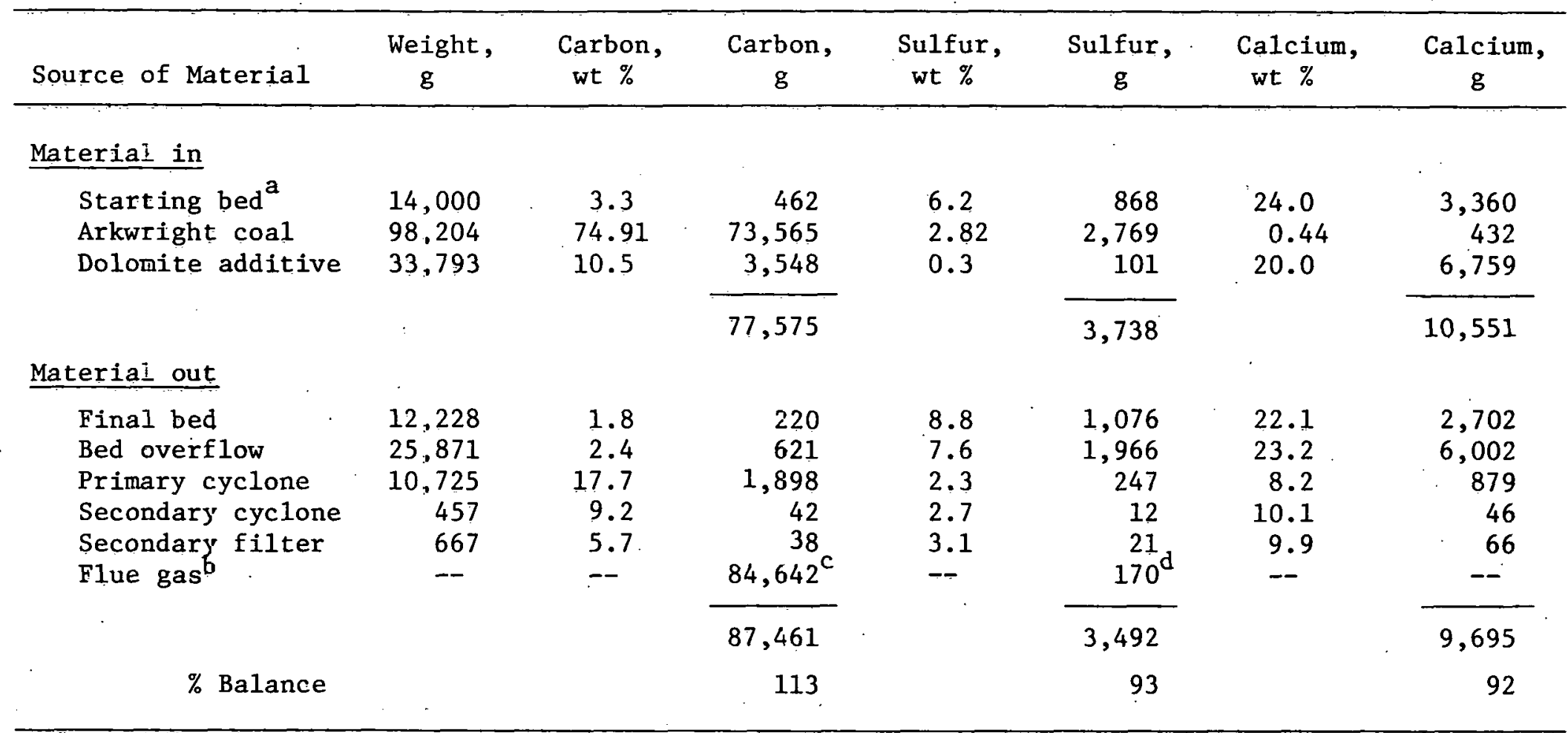

apartially sulfated dolomite.

${ }^{b}$ Avg. flue-gas flowrate (dry basis), cfm at $70^{\circ} \mathrm{F}$ and 1 atm $=47.9$.

${ }^{c}$ Calculated for avg. $\mathrm{CO}$ conc. of $48 \mathrm{ppm}$ plus avg. $\mathrm{CO}_{2}$ conc. of 162,000 ppm.

${ }^{\mathrm{d}}$ Calculated for avg. $\mathrm{SO}_{2}$ conc. of $122 \mathrm{ppm}$. 
Table B-5. Carbon, Sulfur, and Calcium Material Balances Eor VAR-5 Experiment

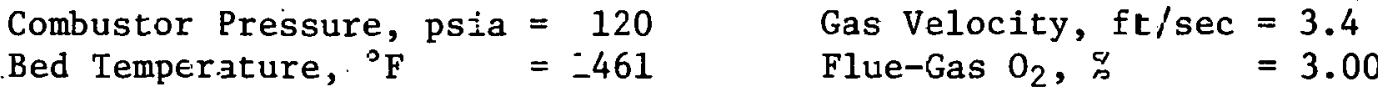

$\mathrm{Ca} / \mathrm{S}$ Mole Ratio

\begin{tabular}{|c|c|c|c|c|c|c|c|}
\hline Source of Material & $\begin{array}{l}\text { Weight, } \\
\quad \mathrm{g}\end{array}$ & $\begin{array}{c}\text { Carbon, } \\
\text { wt } \%\end{array}$ & $\begin{array}{c}\text { Carbon, } \\
\text { g }\end{array}$ & $\begin{array}{l}\text { Sulfur, } \\
\text { wt } \%\end{array}$ & $\begin{array}{c}\text { Sulfur, } \\
\mathrm{g}\end{array}$ & $\begin{array}{l}\text { Calcium, } \\
\text { wt \% }\end{array}$ & $\begin{array}{c}\text { Calcium, } \\
\mathrm{g}\end{array}$ \\
\hline \multicolumn{8}{|l|}{ Material in ${ }^{a}$} \\
\hline $\begin{array}{l}\text { Starting bed } \\
\text { Arkwright coal } \\
\text { Dolomite additive }\end{array}$ & $\begin{array}{r}28,310 \\
195,182 \\
33,113\end{array}$ & $\begin{array}{l}2.74 \\
74.91 \\
10.5\end{array}$ & $\begin{array}{r}777 \\
146,210 \\
3,477\end{array}$ & $\begin{array}{l}9.37 \\
2.82 \\
0.3\end{array}$ & $\begin{array}{r}2,553 \\
5,504 \\
99\end{array}$ & $\begin{array}{c}18.93 \\
0.44 \\
20.0\end{array}$ & $\begin{array}{r}5,360 \\
859 \\
6,622\end{array}$ \\
\hline$\underline{\text { Material out }}^{a^{-}}$ & v & & 150,464 & & 8,256 & & 12,841 \\
\hline $\begin{array}{l}\text { Final bed } \\
\text { Bed overflow } \\
\text { Primary cyclone } \\
\text { Secondary cyclone } \\
\text { Secondary filter } \\
\text { Flue gas } \text { : }\end{array}$ & $\begin{array}{r}31: 890 \\
20: 467 \\
27: 108 \\
3: 452 \\
2: 344 \\
--\end{array}$ & $\begin{array}{r}2.04 \\
2.61 \\
48.83 \\
37.40 \\
23.85 \\
--\end{array}$ & $\begin{array}{r}649 \\
535 \\
13,236 \\
1,291 \\
559 \\
144,572^{d}\end{array}$ & $\begin{array}{r}10.51 \\
9.98 \\
1.59 \\
1.74 \\
2.60 \\
--\end{array}$ & $\begin{array}{r}3.352 \\
2.043 \\
431 \\
60 \\
61 \\
1.696^{\mathrm{e}}\end{array}$ & $\begin{array}{r}17.18 \\
17.38 \\
3.49 \\
3.33 \\
4.18 \\
--\end{array}$ & $\begin{array}{r}5,478 \\
3,557 \\
947 \\
115 \\
98 \\
--\end{array}$ \\
\hline & & & 160,842 & . & 7.643 & & 10,195 \\
\hline$\%$ Balance & $\cdots$ & & . 107 & & 93 & & 7.9 \\
\hline
\end{tabular}

${ }^{a}$ Values shown represent ccmposite data for two segments of the experinent.

bartially sulfated dolomite.

${ }^{\mathrm{C}}$ Avg. flue-gas flowrate (dry basis), $\mathrm{cfm}$ at $70^{\circ} \mathrm{F}$ and 1 atm $=76.6$.

${ }^{d}$ Calculated for avg. Co conc. of $755 \mathrm{ppm} 2 \mathrm{lus}$ avg. $\mathrm{CO}_{2}$ conc. of $154,000 \mathrm{ppm}$.

${ }^{e}$ Calculated for avg. $\mathrm{SO}_{2}$ conc. of $681 \mathrm{ppm}$. 
Table B-6. Carton, Sulfur, and Calcium Material Balances for VAR-6 Experiment

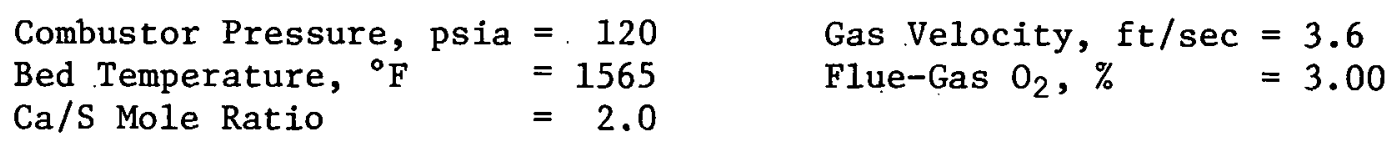

\begin{tabular}{|c|c|c|c|c|c|c|c|}
\hline Source of Material & $\begin{array}{l}\text { Weight, } \\
\text { g }\end{array}$ & $\begin{array}{l}\text { Carbon, } \\
\text { wt \% }\end{array}$ & $\begin{array}{l}\text { Carbon, } \\
\mathrm{g}\end{array}$ & $\begin{array}{l}\text { Sulfur, } \\
\text { wt \% }\end{array}$ & $\begin{array}{l}\text { Sulfur, } \\
\quad \mathrm{g}\end{array}$ & $\begin{array}{l}\text { Calcium, } \\
\text { wt \% }\end{array}$ & $\begin{array}{l}\text { Calcium, } \\
\mathrm{g}\end{array}$ \\
\hline \multicolumn{8}{|l|}{ Material in } \\
\hline $\begin{array}{l}\text { Starting bed } \\
\text { Arkhright coal } \\
\text { Dolcmite additive }\end{array}$ & $\begin{array}{l}14,266 \\
91,854 \\
32,432\end{array}$ & $\begin{array}{l}4.2 \\
74.91 \\
10.5\end{array}$ & $\begin{array}{r}599 \\
68,808 \\
3,405\end{array}$ & $\begin{array}{l}6.3 \\
2.82 \\
0.3\end{array}$ & $\begin{array}{r}899 \\
2,590 \\
97\end{array}$ & $\begin{array}{c}23.1 \\
0.44 \\
20.0\end{array}$ & $\begin{array}{r}3,295 \\
404 \\
6,486\end{array}$ \\
\hline & $:$ & . & 72,812 & & 3,586 & & 10,185 \\
\hline \multicolumn{8}{|l|}{ Materia1 out } \\
\hline $\begin{array}{l}\text { Final bed } \\
\text { Bed overflow } \\
\text { Primary cyclone } \\
\text { Secondary cyclone } \\
\text { Secondary filter } \\
\text { Flue gas }\end{array}$ & $\begin{array}{r}16,210 \\
17,047 \\
16,219 \\
618 \\
492 \\
--\end{array}$ & $\begin{array}{r}4.5 \\
3.8 \\
25.1 \\
19.6 \\
5.7 \\
--\end{array}$ & $\begin{array}{r}729 \\
648 \\
.4,071 \\
133 \\
28 \\
70,601^{\mathrm{c}}\end{array}$ & $\begin{array}{l}7.0 \\
7.0 \\
4.0 \\
2.8 \\
4.2 \\
--\end{array}$ & $\begin{array}{r}1,135 \\
1,193 \\
649 \\
19 \\
21 \\
201^{\mathrm{d}}\end{array}$ & $\begin{array}{c}21.2 \\
22.0 \\
13.2 \\
6.1 \\
7.2 \\
--\end{array}$ & $\begin{array}{r}3,437 \\
3,750 \\
2,141 \\
42 \\
35 \\
--\end{array}$ \\
\hline Flue gas ${ }^{b}$ & & & 76,210 & & 3,218 & & 9,405 \\
\hline$\%$ Balance & & & 105 & & 90 & & 92 \\
\hline
\end{tabular}

a Partially sulfated dolomite.

${ }^{b}$ Avg. flue-gas flowrate (dry basis), $\mathrm{cfm}$ at $70^{\circ} \mathrm{F}$ and $1 \mathrm{~atm}=77.5$.

${ }^{c}$ Calculated for avg. Co conc. of 32 ppm plus avg. $\mathrm{CO}_{2}$ conc. of 158,000 ppm.

dCalculated for avg. $\mathrm{SO}_{2}$ conc. of $169 \mathrm{ppm}$. 
Table B-7. Carbon, Sulfur, and Calcium Material Balances for VAR-6-R Experiment

Combustor Pressure, psia $=120$

Bed Temperature, ${ }^{\circ} \mathrm{F}=1558$

Gas Velocity, $\mathrm{ft} / \mathrm{sec}=3.6$

$\mathrm{Ca} / \mathrm{S}$ Mole Ratio

Flue-Gas $\mathrm{O}_{2}, \% \quad=2.86$

\begin{tabular}{|c|c|c|c|c|c|c|c|}
\hline Source of Material & $\begin{array}{l}\text { Weight, } \\
\text { g }\end{array}$ & $\begin{array}{l}\text { Carbon, } \\
\text { wt } \%\end{array}$ & $\begin{array}{c}\text { Carbon, } \\
\mathrm{g}\end{array}$ & $\begin{array}{l}\text { Sulfur, } \\
\text { wt \% }\end{array}$ & $\begin{array}{l}\text { Sulfur, } \\
\mathrm{g}\end{array}$ & $\begin{array}{l}\text { Calcium, } \\
\text { wt \% }\end{array}$ & $\begin{array}{l}\text { Calcium, } \\
\mathrm{g}\end{array}$ \\
\hline \multicolumn{8}{|l|}{ Material in } \\
\hline $\begin{array}{l}\text { Starting beid } \\
\text { Arkwright coal } \\
\text { Dolomite additive }\end{array}$ & $\begin{array}{l}15,385 \\
84,143 \\
31,298\end{array}$ & $\begin{array}{l}1.6 \\
74.91 \\
10.5\end{array}$ & $\begin{array}{r}246 \\
63,032 \\
3,286\end{array}$ & $\begin{array}{c}10.8 \\
2.82 \\
0.3\end{array}$ & $\begin{array}{r}1,662 \\
2,373 \\
94\end{array}$ & $\begin{array}{c}18.0 \\
0.44 \\
20.0\end{array}$ & $\begin{array}{r}2,769 \\
370 \\
6,260\end{array}$ \\
\hline & & & 66,564 & & 4,129 & & 9,399 \\
\hline Material out & & & & & & & \\
\hline $\begin{array}{l}\text { Final bed } \\
\text { Bed overflow } \\
\text { Primary cyclone } \\
\text { Secondary cyclone } \\
\text { Secondary filter } \\
\text { Flue gas } b\end{array}$ & $\begin{array}{r}13,665 \\
15,194 \\
20,317 \\
642 \\
559 \\
--\end{array}$ & $\begin{array}{r}2.4 \\
2.3 \\
18.8 \\
18.3 \\
9.0 \\
--\end{array}$ & $\begin{array}{r}328 \\
349 \\
3,820 \\
117 \\
50 \\
64,982\end{array}$ & $\begin{array}{l}8.5 \\
8.9 \\
4.6 \\
2.5 \\
3.8 \\
--\end{array}$ & $\begin{array}{r}1,162 \\
1,352 \\
935 \\
16 \\
21 \\
235\end{array}$ & $\begin{array}{r}21.4 \\
21.6 \\
13.8 \\
5.0 \\
5.8 \\
---\end{array}$ & $\begin{array}{r}2,924 \\
3,282 \\
2,804 \\
32 \\
32 \\
--\end{array}$ \\
\hline . & & & 69,646 & & 3,721 & & 9,074 \\
\hline$\%$ Balance & & & 105 & & 90 & & 97 \\
\hline
\end{tabular}

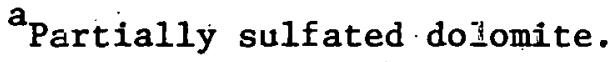

${ }^{b}$ Avg. flue-gas flowrate (dry basis), cfm at $70^{\circ} \mathrm{F}$ and 1 atm $=76.9$.

${ }^{c}$ Calculated for avg. Co conc. of 33 ppm plus avg. $\mathrm{CO}_{2}$ conc. of 154,000 ppm.

${ }^{d}$ Calculated for avg. $\mathrm{SO}_{2}$ conc. of $209 \mathrm{ppm}$. 
Table B-8. Carbon, Sulfur, and Calcium Material Balances for VAR-6-2R Experiment

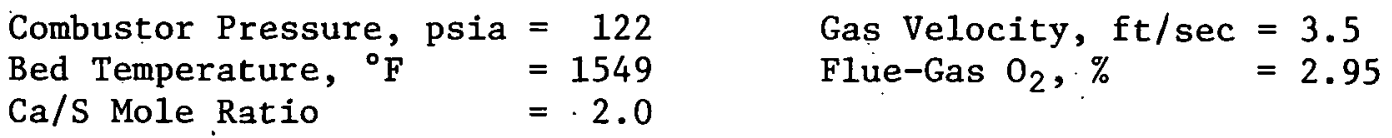

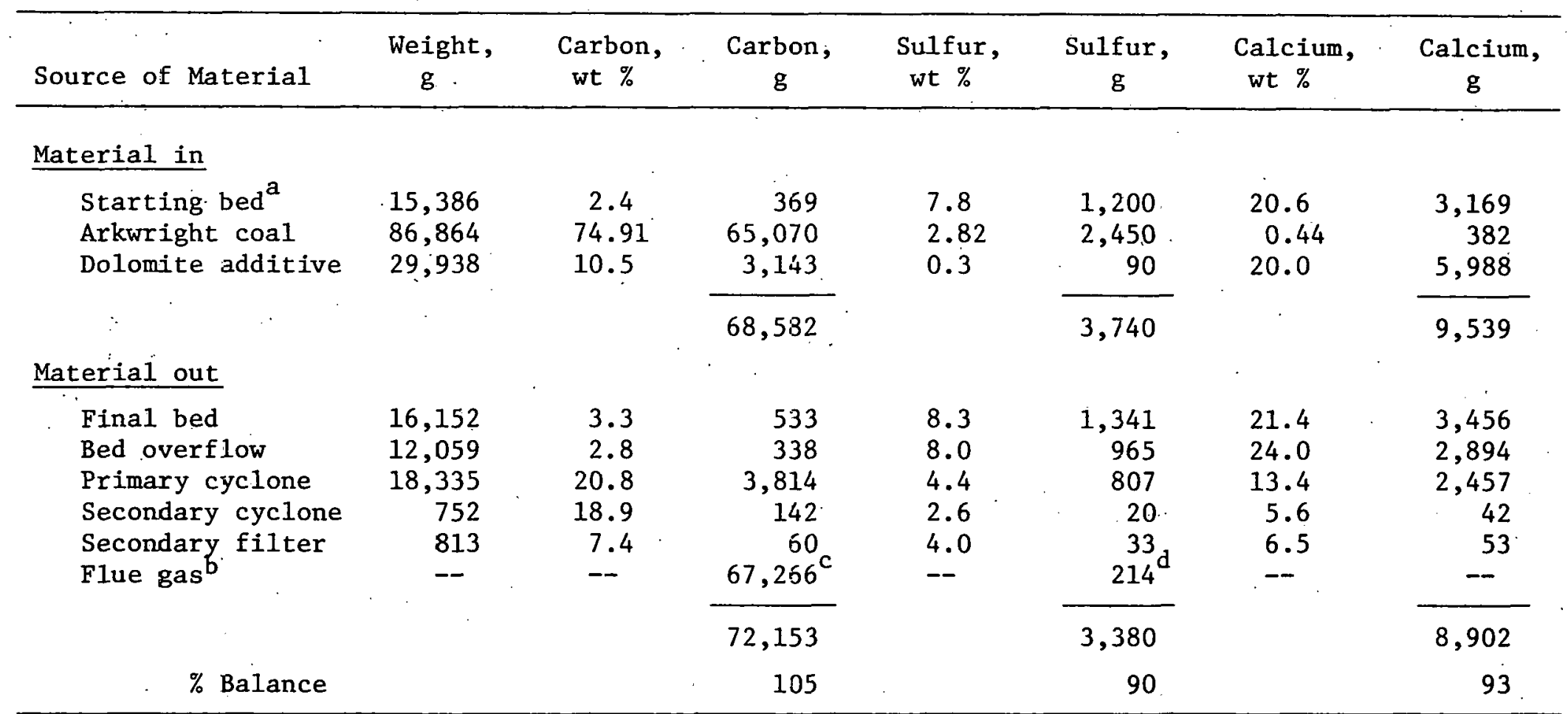

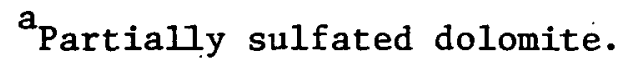

${ }^{b}$ Avg. flue-gas flowrate (dry basis), cfm at $70^{\circ} \mathrm{F}$ and 1 atm $=77.1$.

${ }^{c}$ Calculated for avg. $\mathrm{CO}$ conc. of $33 \mathrm{ppm}$ plus avg. $\mathrm{CO}_{2}$ conc. of 159,000 ppm.

${ }^{\mathrm{d}}$ Calculated for avg. $\mathrm{SO}_{2}$ conc. of $190 \mathrm{ppm}$. 
Table B-9. Carbon, Sulfur, and Calcium Material Balances for VAR-7 Experiment

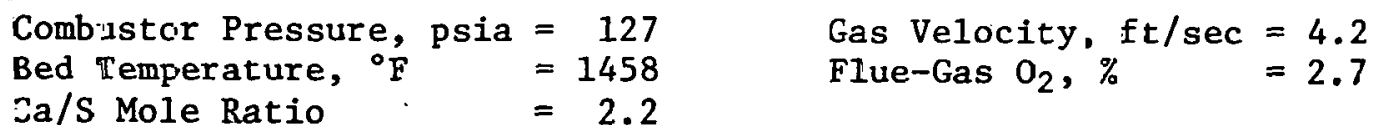

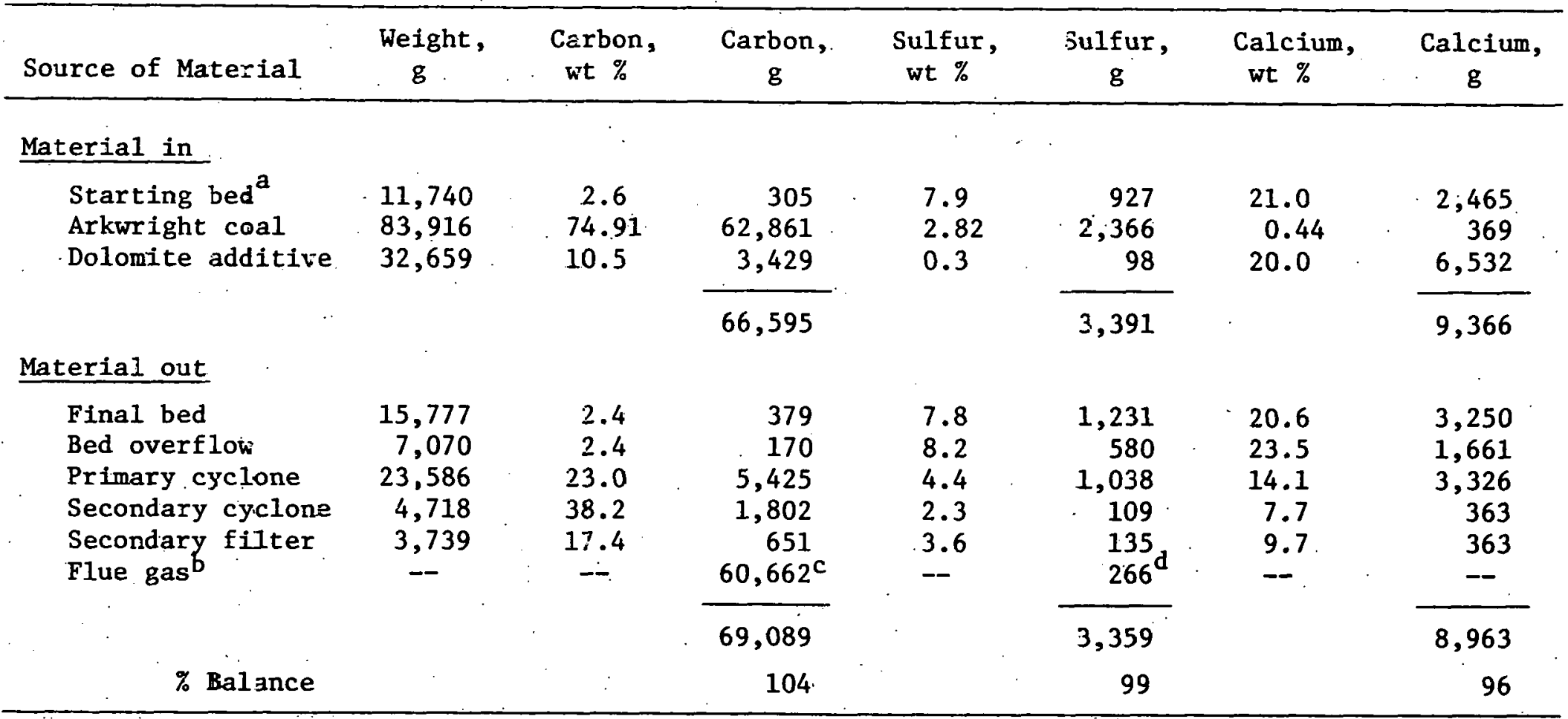

\footnotetext{
a Partialiy sulfated dolomite.

${ }^{\mathrm{b}}$ Avg. flue-gas Flowrate' (dry basis), cfm at $70^{\circ} \mathrm{F}$ and 1 atm $=100.4$.

${ }^{c}$ Calculated for avg. Co conc. of 86 ppm plus avg. $\mathrm{CO}_{2}$ conc. of 159,000 ppm.

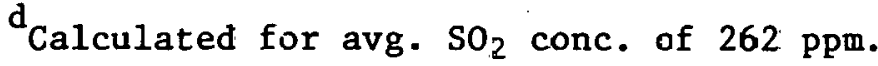


Table B-10. Carbon, Sulfur, and Calcium Material Balances for VAR-8 Experiment

$\begin{array}{llll}\text { Combustor Pressure, psia } & =120 & & \text { Gas Velocity, ft/sec }=3.6 \\ \text { Bed Temperature, }{ }^{\circ} \mathrm{F} & =1630 & \text { Flue-Gas } 0_{2}, \% & =3.05 \\ \text { Ca/S Mole Ratio } & =3.2 & \end{array}$

\begin{tabular}{|c|c|c|c|c|c|c|c|}
\hline Source of Material & $\begin{array}{l}\text { Weight, } \\
\quad \mathrm{g}\end{array}$ & $\begin{array}{l}\text { Carbon, } \\
\text {-wt \% }\end{array}$ & $\begin{array}{c}\text { Carbon, } \\
\mathrm{g}\end{array}$ & $\begin{array}{l}\text { Sulfur, } \\
\text { wt \% }\end{array}$ & $\begin{array}{c}\text { Sulfur } \\
\mathrm{g}\end{array}$ & $\begin{array}{l}\text { Calcium, } \\
\text { wt } \%\end{array}$ & $\begin{array}{c}\text { Calcium, } \\
\mathrm{g}\end{array}$ \\
\hline Material in & & & & & & & : \\
\hline $\begin{array}{l}\text { Starting bed } \\
\text { Arkwright coal } \\
\text { Dolomite additive }\end{array}$ & $\begin{array}{l}15,565 \\
65,318 \\
36,742\end{array}$ & $\begin{array}{l}4.0 \\
74.91 \\
10.5\end{array}$ & $\begin{array}{r}623 \\
48,930 \\
3,858\end{array}$ & $\begin{array}{l}5.8 \\
2.82 \\
0.3\end{array}$ & $\begin{array}{r}903 \\
1,842 \\
110\end{array}$ & $\begin{array}{c}24.4 \\
0.44 \\
20.0\end{array}$ & $\begin{array}{r}3,798 \\
287 \\
7,348\end{array}$ \\
\hline & $\cdot$. & & 53,411 & & 2,855 & & 11,433 \\
\hline Material out & & & & . & & 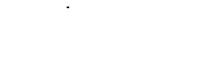 & \\
\hline Final bed & 15.787 & 3.3 & 521 & 6.2 & 979 & 24.0 & 3,789 \\
\hline Bed overflow & $12: 928$ & 3.4 & 439 & 5.7 & 7.37 & 24.1 & 3,116 \\
\hline Primary cyclone & 20.054 & 11.6 & 2,326 & 4.1 & 822 & 20.1 & 4,031 \\
\hline Secondary cyclone & 874 & 8.5 & 74 & 3.0 & 26 & 9.9 & 87 \\
\hline Secondary filter & 545 & 4.6 & 25 & 3.5 & 19 & 9.9 & 54 \\
\hline Flue gas $^{\mathrm{t}}$ & -- & -- & $58,771^{c}$ & -- & $118^{\mathrm{d}}$ & -- & -- \\
\hline$:$ & & $\cdot$ & 62,156 & & 2,701 & & 11,077 \\
\hline$\%$ Balance & & & 116 & & 95 & & 97 \\
\hline
\end{tabular}

\footnotetext{
a Partially sulfated dolomite.

${ }^{b}$ Avg. flue-gas flowrate (dry basis), cfm at $70^{\circ} \mathrm{F}$ and 1 atm $=76.5$.

${ }^{c}$ Calculated for avg. Co conc. of $45 \mathrm{ppm}$ plus avg. $\mathrm{CO}_{2}$ conc. of $174,000 \mathrm{ppm}$.

d. Calculated for avg. $\mathrm{SO}_{2}$ conc. of $131 \mathrm{ppm}$.
} 
Table B-11. Carbon, Sulfur, and Calcium Material Balances for VAR-9 Experiment

$\begin{array}{rlrlrl}\text { Combustor Pressure, psia } & =121 & & \text { Gas Velocity, ft } / \mathrm{sec} & =4.9 \\ \text { Bed Temperature, }{ }^{\circ} \mathrm{F} & =1665 & & \text { Flue-Gas } 0_{2}, \% & =2.93 \\ \mathrm{Ca} / \mathrm{S} \mathrm{Mole} \mathrm{Ratio} & =1.0 & & \end{array}$

\begin{tabular}{|c|c|c|c|c|c|c|c|}
\hline Source of Macerial & $\begin{array}{l}\text { Weight, } \\
\mathrm{g}\end{array}$ & $\begin{array}{c}\text { Carbon, } \\
\text { wt \% }\end{array}$ & $\begin{array}{c}\text { Carbon, } \\
\mathrm{g}\end{array}$ & $\begin{array}{l}\text { Sulfur; } \\
\text { wt \% }\end{array}$ & $\begin{array}{l}\text { Sulfur, } \\
\mathrm{g}\end{array}$ & $\begin{array}{l}\text { Calcium, } \\
\text { wt } \%\end{array}$ & $\begin{array}{c}\text { Calcium, } \\
\mathrm{g}\end{array}$ \\
\hline Material in & .. & & & & & & \\
\hline \multirow[t]{2}{*}{$\begin{array}{l}\text { Starting bed }{ }^{2} \\
\text { Arkwright coal } \\
\text { Dolomite additive }\end{array}$} & $\begin{array}{r}11,761 \\
206,615 \\
.35,608\end{array}$ & $\begin{array}{l}3.3 \\
7<.91 \\
10.5\end{array}$ & $\begin{array}{r}388 \\
154,775 \\
3,739\end{array}$ & \multirow[t]{2}{*}{$\begin{array}{l}8.3 \\
2.82 \\
0.3\end{array}$} & $\begin{array}{r}976 \\
.526 \\
107\end{array}$ & $\begin{array}{c}21.4 \\
0.44 \\
20.0\end{array}$ & $\begin{array}{r}2,517 \\
909 \\
7,122\end{array}$ \\
\hline & & & 158,902 & & 5,909 & & 10,548 \\
\hline \multirow[t]{2}{*}{$\begin{array}{l}\text { Final bed } \\
\text { Bed overflow } \\
\text { Primary cyclone } \\
\text { Secondary cyclone } \\
\text { Secondary filter } \\
\text { Flue gas }\end{array}$} & $\begin{array}{r}14,279 \\
9,338 \\
45,430 \\
1,531 \\
1,370 \\
--\end{array}$ & $\begin{array}{r}0.5 \\
0.9 \\
30.0 \\
14.9 \\
5.3 \\
-\end{array}$ & $\begin{array}{r}71 \\
84 \\
13,629 \\
228 \\
73 \\
157,114^{c}\end{array}$ & $\begin{array}{r}11.7 \\
10.5 \\
3.5 \\
2.8 \\
4.7 \\
--\end{array}$ & $\begin{array}{r}1,671 \\
980 \\
-, 590 \\
43 \\
64 \mathrm{~d} \\
2,229 \mathrm{~d}\end{array}$ & $\begin{array}{l}17.7 \\
20.4 \\
11.4 \\
6.4 \\
.6 .6 \\
--\end{array}$ & $\begin{array}{c}2,527 \\
1,905 \\
5,179 \\
98 \\
90 \\
--\end{array}$ \\
\hline & & & 171,199 & & 6,577 & . & 9,799 \\
\hline \% Balance & & & 108 & & $95^{\circ}$ & & 93 \\
\hline
\end{tabular}

\footnotetext{
a Partially sulfated dolomite.

${ }^{\mathrm{b}}$ Avg. flue-gas flowrate (dry basis), $\mathrm{cfm}$ at $70^{\circ} \mathrm{F}$ and $1 \mathrm{~atm}=100.3$

${ }^{c}$ Calculated for avg. Co conc. of $38 \mathrm{ppm}$ plus avg. $\mathrm{CO}_{2}$ conc. of $159,0 \mathrm{CH} \mathrm{ppm}$.

${ }^{\mathrm{d}} \mathrm{Calculated}$ for avg. $\mathrm{SO}_{2}$ conc. of $846 \mathrm{ppm}$.
} 
Table B-12. Carjon, Sulfur, and Calcium Material Balances for Experiment LIG-1

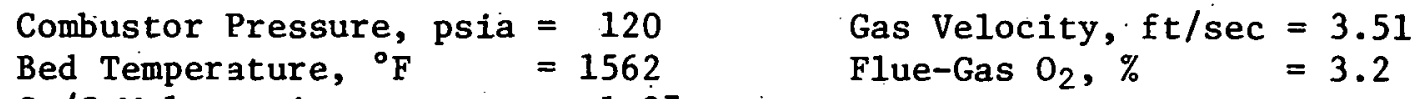

(excluding $\mathrm{Ca}$ in coal)

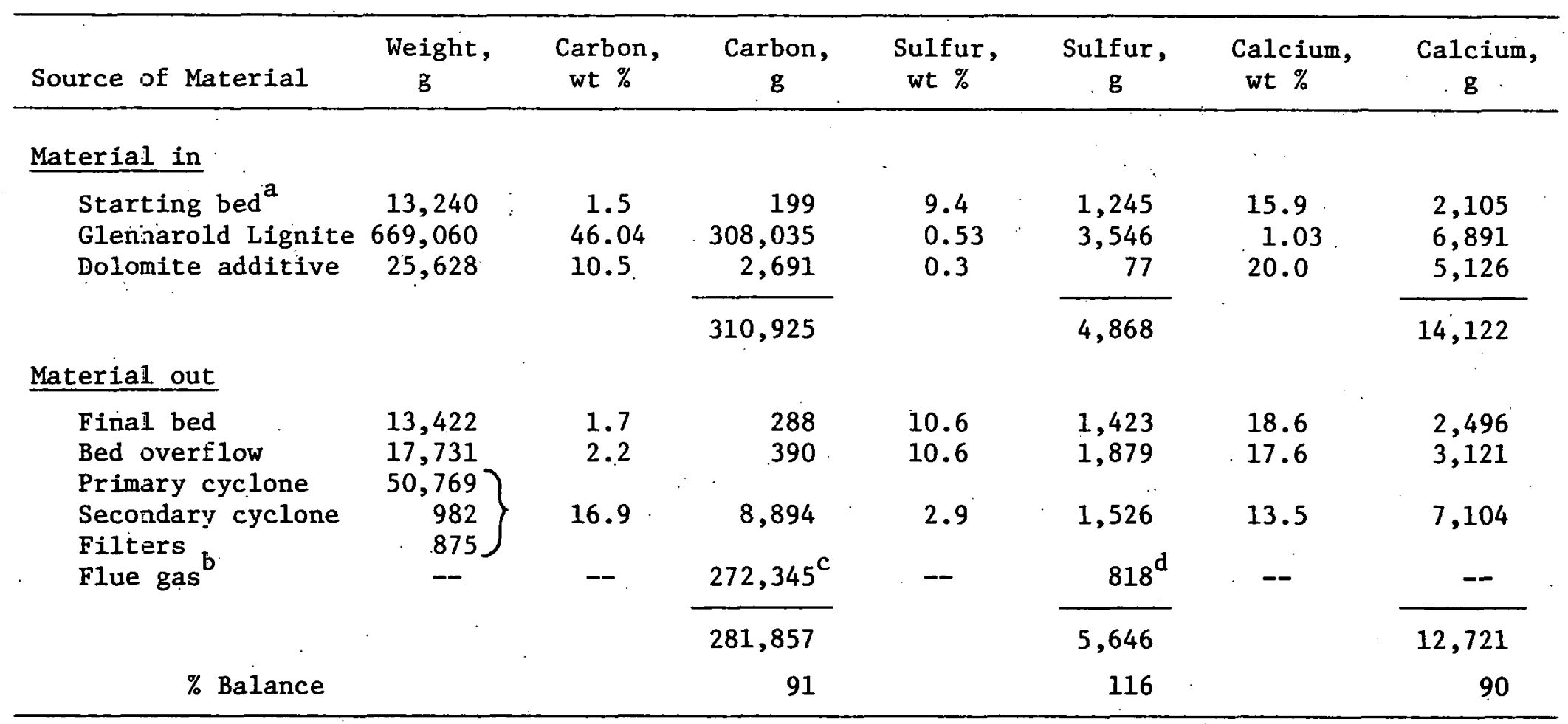

\footnotetext{
a Partially sulfated dolomite.

${ }^{b}$ Avg. flue-gas flowrate (dry basis), $\operatorname{cfm}$ at $70^{\circ} \mathrm{F}$ and 1 atm $=75.9$.

${ }^{c}$ Calculated for avg. $\mathrm{CO}$ conc. of $123 \mathrm{ppm}$ plus avg. $\mathrm{CO}_{2}$ conc. of 172,000 ppm.

${ }^{\mathrm{d}}$ Calculated for avg. $\mathrm{SO}_{2}$ eonc. of $194 \mathrm{ppm}$.
} 
Table B-13. Carbon, Sulfur, and Calcium Material Balances for Experiment SJ-1A

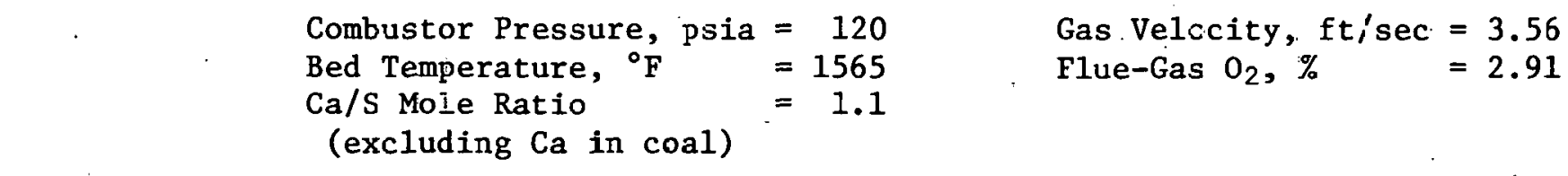

Gas Velccity, ftísec $=3.56$

\begin{tabular}{cccccccc}
\hline & Weight, & Cazbon, & Carbon, & Sulfur, & Sulfur, & Calcium, & Calcium, \\
st $\%$ & $\mathrm{wt} \%$ & $\mathrm{~g}$ & $\mathrm{~g}$ & $\mathrm{wt} \%$ & $\mathrm{~g}$ \\
\hline
\end{tabular}

\section{Material in}

$\begin{array}{lrc}\text { Starting bed } & 16,356 & \\ \text { San Juan coal } & 449,971 & 55.8 \\ \text { Dolomite additive } & 30,164 & 10.5\end{array}$

\section{Material out}

Final bed Bed overflow

Primary cyclone Secondary cyclone Filters

Flue gas ${ }^{b}$

$\begin{array}{r}180 \\ 251,174 \\ 3,167 \\ \hline 254,521\end{array}$

$\begin{array}{rr}11.0 & 1,799 \\ 0.78 & 3,510 \\ 0.3 & 90 \\ & 5,399\end{array}$

16.3

0.75

$\begin{array}{r}2,666 \\ 3,375 \\ 6,033 \\ \hline 12,074\end{array}$

20.0

\begin{tabular}{r}
1,245 \\
2,294 \\
1,107 \\
$1,213^{d}$ \\
\hline 5,859 \\
108
\end{tabular}

15.9
16.4
3.6
-
-

\begin{tabular}{r}
2,105 \\
3,584 \\
3,321 \\
-- \\
\hline 9,010 \\
7.5
\end{tabular}

\footnotetext{
a Partially sulfated dolomite.

${ }^{\mathrm{b}}$ Avg. flue-gas flowrate (dry basis) at $70^{\circ} \mathrm{F}$ and 1 atm $=76.5$.

${ }^{c}$ Calculated for avg. CO conc. of $46 \mathrm{ppm}$ plus avg. $\mathrm{CO}_{2}$ conc. of 166,000 ppm.

${ }^{d}$ Calculated for avg. $\mathrm{SO}_{2}$ conc. of $321 \mathrm{ppm}$.
} 
APPENDIX C. SCREEN ANALYSIS DATA 
Table C-1. Sieve Analysis of Bed and Elutriated Solids from "VAR" Experiments

\begin{tabular}{|c|c|c|c|c|c|c|c|c|c|c|c|}
\hline $\begin{array}{l}\text { RUN NO. } \\
\text { Temp, }{ }^{\circ} \mathrm{F} \\
\text { Ca/s, Mole Ratio } \\
\text { Gas Velocity, ft/sec }\end{array}$ & $\begin{array}{c}2 \\
1550 \\
3 \\
4.8\end{array}$ & $\begin{array}{c}7 \\
1450 \\
2 \\
4.2\end{array}$ & $\begin{array}{c}9 \\
1650 \\
1 \\
4.9\end{array}$ & $\begin{array}{c}5 \\
1450 \\
1 \\
3.4\end{array}$ & $\begin{array}{c}6 \\
1550 \\
2 \\
3.6\end{array}$ & $\begin{array}{c}6-\mathrm{R} \\
1550 \\
2 \\
3.6\end{array}$ & $\begin{array}{c}6-2 \mathrm{R} \\
1550 \\
2 \\
3.5\end{array}$ & $\begin{array}{c}8 \\
1650 \\
3 \\
3.6\end{array}$ & $\begin{array}{c}1 \\
1450 \\
3 \\
2.1\end{array}$ & $\begin{array}{c}3 \\
1550 \\
1 \\
2.1\end{array}$ & $\begin{array}{c}4 \\
1650 \\
2 \\
2.3\end{array}$ \\
\hline 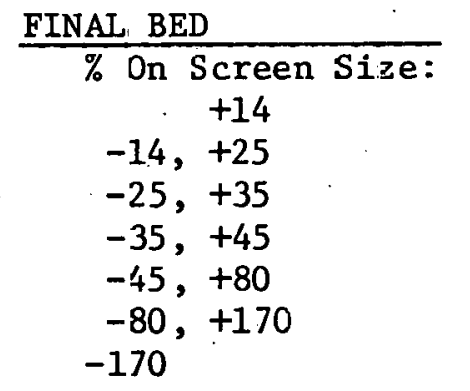 & $\begin{array}{r}0.5 \\
71.3 \\
26.6 \\
1.4 \\
0.1 \\
0.1 \\
0.0\end{array}$ & $\begin{array}{r}0.8 \\
51.2 \\
31.5 \\
15.0 \\
1.6 \\
0.0 \\
0.0\end{array}$ & $\begin{array}{r}0.7 \\
52.4 \\
43.8 \\
2.9 \\
0.2 \\
0.0 \\
0.0\end{array}$ & $\begin{array}{r}0.4 \\
49.2 \\
35.7 \\
12.4 \\
2.3 \\
0.0 \\
0.0\end{array}$ & $\begin{array}{r}0.6 \\
64.7 \\
29.8 \\
5.0 \\
0.0 \\
0.0 \\
0.0\end{array}$ & $\begin{array}{r}0.5 \\
53.7 \\
34.6 \\
10.7 \\
0.5 \\
0.0 \\
0.0\end{array}$ & $\begin{array}{r}0.5 \\
48.5 \\
39.8 \\
10.0 \\
1.2 \\
0.0 \\
0.0\end{array}$ & $\begin{array}{r}0.0 \\
45.9 \\
42.2 \\
10.4 \\
1.4 \\
0.0 \\
0.0\end{array}$ & $\begin{array}{r}0.6 \\
44.4 \\
33.4 \\
15.0 \\
6.7 \\
0.0 \\
0.0\end{array}$ & $\begin{array}{r}0.0 \\
31.8 \\
28.7 \\
19.0 \\
20.3 \\
0.2 \\
0.0\end{array}$ & $\begin{array}{r}0.0 \\
37.3 \\
35.1 \\
17.3 \\
10.2 \\
0.0 \\
0.0\end{array}$ \\
\hline Mean Particle Iia, $\mu \mathrm{m}$ & 930 & 813 & 846 & 803 & 897 & 833 & $8 C .8$ & 787 & 765 & 643 & 706 \\
\hline $\begin{array}{l}\text { OVERFEOW. } \\
\begin{array}{c}\text { Wt } \% \text { On Screen Size: } \\
+14 \\
-14,+25 \\
-25,+35 \\
-35 ;+45 \\
-45,+80 \\
-30,+170 \\
-170\end{array}\end{array}$ & $\begin{array}{r}0.3 \\
75.9 \\
18.2 \\
2.6 \\
1.6 \\
0.2 \\
0.2\end{array}$ & $\begin{array}{r}0.0 \\
45.3 \\
23.4 \\
7.1 \\
24.1 \\
0.1 \\
0.1\end{array}$ & $\begin{array}{r}0.7 \\
66.9 \\
29.4 \\
2.7 \\
0.2 \\
0.2 \\
0.0\end{array}$ & $\begin{array}{r}1.0 \\
60.7 \\
28.3 \\
8.6 \\
1.4 \\
0.0 \\
0.0\end{array}$ & $\begin{array}{r}1.0 \\
73.7 \\
22.6 \\
2.8 \\
0.0 \\
0.0 \\
0.0\end{array}$ & $\begin{array}{r}1.2 \\
67.7 \\
25.5 \\
5.6 \\
0.1 \\
0.0 \\
0.0\end{array}$ & $\begin{array}{r}0.5 \\
61.4 \\
30.4 \\
6.9 \\
0.8 \\
0.0 \\
0.0\end{array}$ & $\begin{array}{r}0.0 \\
53.6 \\
34.4 \\
5.5 \\
0.5 \\
0.0 \\
0.0\end{array}$ & $\begin{array}{r}3.7 \\
22.3 \\
50.5 \\
17.2 \\
4.2 \\
0.8 \\
1.2\end{array}$ & $\begin{array}{r}0.0 \\
26.7 \\
29.4 \\
20.2 \\
23.1 \\
0.5 \\
0.2\end{array}$ & $\begin{array}{r}0.0 \\
69.4 \\
23.3 \\
5.5 \\
1.8 \\
0.0 \\
0.0\end{array}$ \\
\hline Mean Particle Dia, $\mu_{n}$ & 945 & 714 & 909 & 874 & 947 & 919 & 874 & 856 & 704 & 607 & 902 \\
\hline
\end{tabular}


Table C-1. (Cont'd.). Sieve Analysis of Bed and Elutriated Solids from "VAR" Experiments

\begin{tabular}{|c|c|c|c|c|c|c|c|c|c|c|c|}
\hline $\begin{array}{l}\text { RUN No. } \\
\text { Temp, }{ }^{\circ} \mathrm{F} \\
\text { Ca/S, Mole Ratio } \\
\text { Gas Velocity, ft/sec }\end{array}$ & $\begin{array}{c}2 \\
1550 \\
3 \\
4.8\end{array}$ & $\begin{array}{c}7 \\
1450 \\
2 \\
4.2\end{array}$ & $\begin{array}{c}9 \\
1650 \\
1 \\
4.9\end{array}$ & $\begin{array}{c}5 \\
1450 \\
1 \\
3.4\end{array}$ & $\begin{array}{c}6 \\
1550 \\
2 \\
3.6\end{array}$ & $\begin{array}{l}6-R \\
1550 \\
2 \\
3.6\end{array}$ & $\begin{array}{c}6-2 \mathrm{R} \\
1550 \\
2 \\
3.5\end{array}$ & $\begin{array}{c}8 \\
1650 \\
3 \\
3.6\end{array}$ & $\begin{array}{c}1 \\
1450 \\
3 \\
2.1\end{array}$ & $\begin{array}{c}3 \\
1550 \\
1 \\
2.1\end{array}$ & $\begin{array}{c}4 \\
1650 \\
2 \\
2.3\end{array}$ \\
\hline PRIMARY CYCLONE & & & & & & & & & & & \\
\hline $\begin{array}{c}\text { Wt } \% \text { Screen Size: } \\
+45 \\
-45,+80 \\
-80,+100 \\
-100,+170 \\
-170,+230 \\
-230,+325 \\
-325\end{array}$ & $\begin{array}{r}51.9 \\
23.1 \\
1.9 \\
7.9 \\
3.9 \\
3.9 \\
7.7\end{array}$ & $\begin{array}{r}47.2 \\
24.5 \\
1.9 \\
7.6 \\
3.8 \\
3.8 \\
11.3\end{array}$ & $\begin{array}{r}38.2 \\
23.5 \\
2.9 \\
8.8 \\
5.9 \\
5.9 \\
14.7\end{array}$ & $\begin{array}{r}8.4 \\
23.0 \\
9.5 \\
16.0 \\
7.9 \\
9.1 \\
26.2\end{array}$ & $\begin{array}{r}34.6 \\
23.1 \\
3.9 \\
11.5 \\
3.9 \\
7.7 \\
15.4\end{array}$ & $\begin{array}{r}36.9 \\
24.1 \\
4.8 \\
7.3 \\
3.6 \\
4.2 \\
19.1\end{array}$ & $\begin{array}{r}48.2 \\
25.0 \\
1.8 \\
7.1 \\
3.6 \\
3.6 \\
10.7\end{array}$ & $\begin{array}{r}47.7 \\
23.1 \\
1.5 \\
6.2 \\
3.1 \\
4.6 \\
13.9\end{array}$ & $\begin{array}{r}4.0 \\
12.0 \\
4.0 \\
16.0 \\
12.0 \\
16.0 \\
36.0\end{array}$ & $\begin{array}{r}0.0 \\
19.7 \\
14.1 \\
32.4 \\
15.5 \\
18.3 \\
0.0\end{array}$ & $\begin{array}{r}5.8 \\
15.4 \\
3.9 \\
13.5 \\
7.7 \\
9.6 \\
44.2\end{array}$ \\
\hline Mean Particle Dia, $\mu \mathrm{m}$ & 257 & 244 & 208 & 142 & 193 & 229 & 249 & 244 & 61 & 124 & 97 \\
\hline $\begin{array}{c}\text { SECONDARY CYCLONE } \\
\text { Wt } \% \text { on Screen Size: } \\
+45 \\
-45,+80 \\
-80,+100 \\
-100,+170 \\
-170,+230 \\
-230,+325 \\
-325\end{array}$ & $\begin{array}{r}16.4 \\
6.0 \\
6.0 \\
7.5 \\
3.0 \\
3.0 \\
58.2\end{array}$ & $\begin{array}{r}51.2 \\
17.1 \\
2.4 \\
7.3 \\
4.9 \\
4.9 \\
12.2\end{array}$ & $\begin{array}{r}6.7 \\
6.7 \\
2.2 \\
8.9 \\
6.7 \\
8.9 \\
60.0\end{array}$ & $\begin{array}{r}5.9 \\
17.7 \\
0.0 \\
17.7 \\
11.8 \\
11.8 \\
35.3\end{array}$ & $\begin{array}{r}9.1 \\
9.9 \\
4.6 \\
9.1 \\
4.6 \\
9.1 \\
54.6\end{array}$ & $\begin{array}{r}4.4 \\
4.4 \\
0.0 \\
4.4 \\
4.4 \\
4.4 \\
78.3\end{array}$ & $\begin{array}{r}4.9 \\
12.2 \\
9.8 \\
14.6 \\
9.8 \\
9.8 \\
39.0\end{array}$ & $\begin{array}{r}20.0 \\
6.7 \\
2.2 \\
4.4 \\
6.7 \\
4.4 \\
55.6\end{array}$ & $\begin{array}{r}15.8 \\
10.5 \\
0.0 \\
10.5 \\
10.5 \\
15.8 \\
36.8\end{array}$ & $\begin{array}{r}3.7 \\
3.7 \\
0.0 \\
7.4 \\
7.4 \\
14.8 \\
63.0\end{array}$ & $\begin{array}{r}11.1 \\
4.4 \\
2.2 \\
4.4 \\
4.4 \\
4.4 \\
68.9\end{array}$ \\
\hline Mean Partićle Dia, $\mu \mathrm{m}$ & 109 & 241 & 61 & 74 & 69 & 43 & 91 & 107 & 79 & 36 & 71 \\
\hline
\end{tabular}


Table C-1 (Cont ${ }^{-d .) . ~ S i e v e ~ A n a l y s i s ~ c f ~ B e d ~ a n d ~ E l u t r i a t e d ~ S o l z d s ~ f r o m ~ " V A R " ~ E x p e r i m e n t s ~}$

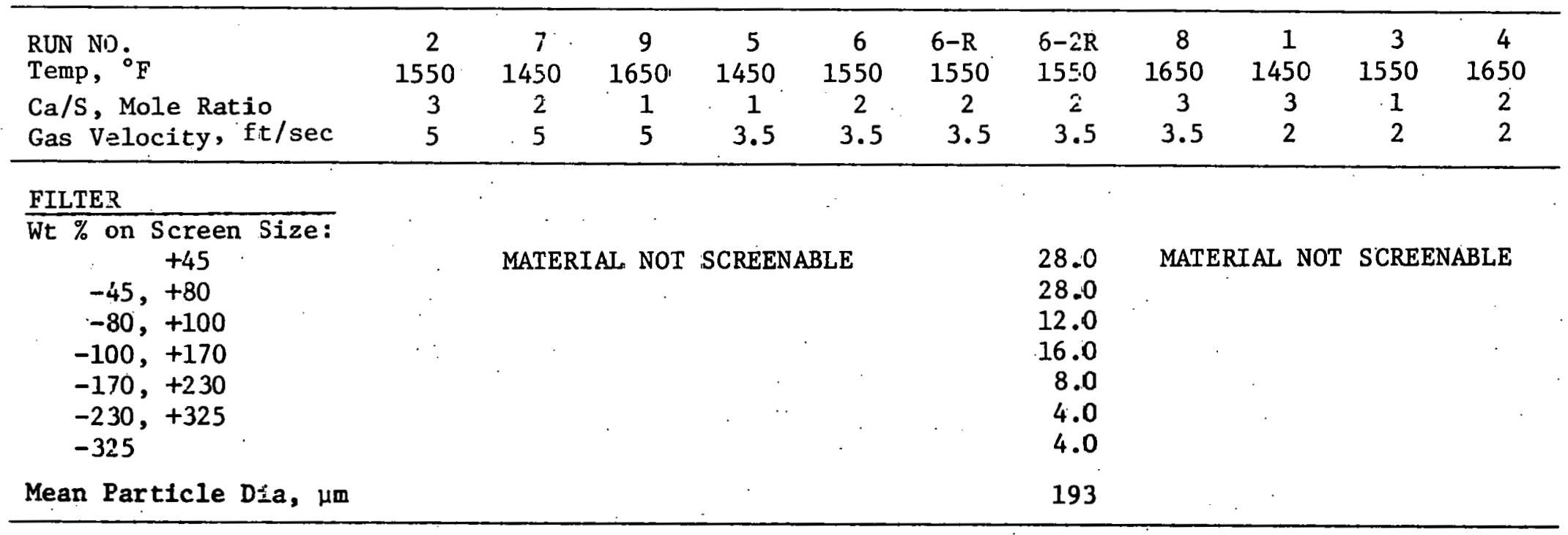


Table C-2. Particle-Size Distribution of Bed and Elutriated Solids for SJ-1A and LIG-1 Experiments

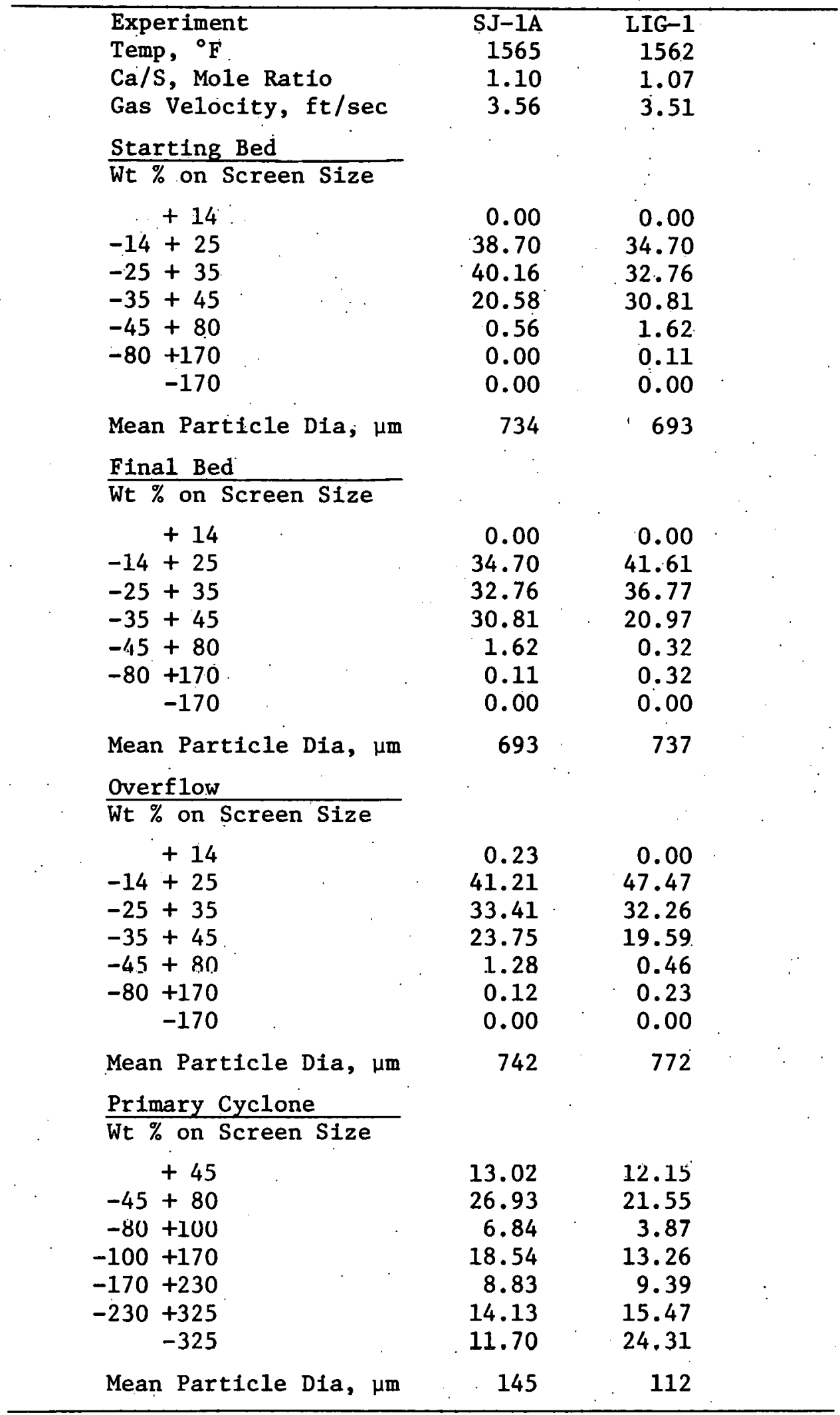


APPENDIX D. CONCENTRATION OF FINE PARTICULATE MATTER IN THE FLUE GAS EXHAUSTED FROM THE FLUIDIZED-BED COMBUSTION SYSTEM 


\section{APPENDIX D. CONCENTRATION OF FINE PARTICULATE MATTER IN THE FLUE GAS EXHAUSTED FROM THE FLUIDIZED-BED COMBUSTION SYSTEM}

A Brink, five-stage inertial impactor, capable of sampling and classifying gas-entrained particulate matter into five size ranges from 20.3 to $3.0 \mu \mathrm{m}$ in diameter, was an integral component of the mercury and fluoride sampling train used in the trace-element distribution studies. As illustrated in Figs. 22 and 23 of the text, sampling of the flue gas was accomplished as the gas was being vented from the system, i.e., after the flue gas had passed through the particulate removal devices (cyclones and fitters) and the system-pressure control valve. The impactor, together with an in-line cyclone and glass fiber filter, removed the fine particulate emissions from the sample of flue gas before the sample passed through the fluoride and mercury scrubbing solutions (see Fig. 23). Details concerning the impactor and the sampling apparatus are included in both this report (pp.71-73) and in a previous annual report. 26

With the Brink impactor, it was possible during the operation of the mercury and fluoride sampling equipment to obtain a limited amount of data on the loading and size distribution of the fine particulate emissions ( 0.3 to $3.0 \mu \mathrm{m}$ particles) in the flue gas being vented from the combustion system.

It should be emphasized, that the data reported here are not necessarily representative of the loadings and particle-size distributions that would be obtained in a commercial unit with an optimally designed system for the high-temperature removal of fine particulate matter from the flue gas. The data are presented here as a reporting of what was observed and as a possible basis for making future comparisons and evaluations.

With this understanding, Table D-1 summarizes the data obtained with the Brink impactor. The first three experiments in the table were performed with two cyclone stages and a single filter stage in the off-gas clean-up system. The loadings are still quite high, ranging from 0.051 to 0.089 grains $/ \mathrm{ft}^{3}$. The last three experiments in the table, made with two cyclone stages and two filter stages in the off-gas clean-up system, exhibited concentration levels which should be compatible with the requirements for use with a gas turbine. 
TABLE D-1. Fine Particulate Emissions for Selected Combustion Experiments

\begin{tabular}{|c|c|c|c|c|c|c|c|c|c|c|}
\hline \multirow[b]{2}{*}{ Experiment } & \multirow{2}{*}{$\begin{array}{c}\text { Operating } \\
\text { Conditions } \\
\text { Summarized } \\
\text { in Text } \\
\text { Table No. }\end{array}$} & \multicolumn{8}{|c|}{ Particulete Matter Recovered on Each Stage, mg } & \multirow[b]{2}{*}{$\begin{array}{l}\text { Emissions, } \\
\text { grains/ft } \\
\text { at } 70^{\circ} \mathrm{F}, 1 \text { atm } \\
\text { (dry basis) }\end{array}$} \\
\hline & & $\begin{array}{l}\text { In-Line } \\
\text { Cyclone }\end{array}$ & $\begin{array}{c}\text { Stage } \\
- \\
\left(\begin{array}{c}3.6- \\
4.0\end{array}\right) \\
\end{array}$ & $\begin{array}{c}\text { Stage } \\
2 \\
(2.0)\end{array}$ & $\begin{array}{c}\text { Stage } \\
3 \\
(1.2)\end{array}$ & $\begin{array}{c}\text { Stage } \\
4 \\
(0.8)\end{array}$ & $\begin{array}{c}\text { Stage } \\
5 \\
(0.4)\end{array}$ & $\begin{array}{l}\text { Wa11 } \\
\text { Losses }\end{array}$ & Filter & \\
\hline TRACE $-3^{b}$ & 17 & 15.2 & 20.9 & 26.5 & 13.8 & 6.3 & 4.4 & 12.7 & 9.4 & 0.089 \\
\hline TRACE $-4 B^{b}$ & 17 & 10.5 & 13.6 & 12.4 & 10.3 & 7.7 & ד. & 1.7 & 18.9 & 0.064 \\
\hline $\mathrm{VAR}-7^{\mathrm{b}}$ & 2 & 9.3 & 11.8 & 12.2 & 15.6 & 6.7 & 7.3 & 3.4 & 13.0 & 0.051 . \\
\hline VAR-9 & 2 & $T^{d}$ & 0.7 & 0.8 & 0.4 & $T$ & $\mathrm{~T}$ & $T$ & 0.6 & 0.001 \\
\hline TRACE $-5 \dot{A}^{C}$ & 17 & $\mathbf{T}$ & $\mathbf{T}$ & $\mathrm{T}$ & $\mathrm{T}$ & 0.1 & 0.1 & $\mathrm{~T}$ & 0.6 & $<0.001$ \\
\hline TRACE $-\sigma^{c}$ & 17 & $T$ & 0.1 & $\mathrm{~T}$ & $T$ & $\mathrm{~T}$ & $\mathrm{~T}$ & $\mathrm{~T}$ & 0.6 & $<0.001$ \\
\hline
\end{tabular}

${ }^{a}$ Geometric mean particle diameter in microns. Determined by means of a computor program furnished by Mr. Bruce Harris, Research Branch, Control Systems Laboracory, Natiora: Environmental Research Center, Research Triangle Park, North Carolina and substantiated by analysis of photomicrographs of material impacted on the various stages.

${ }^{b}$ Experiments performed with 2 cyclone stages and 1 filter stage ir off-gas clean-up system.

cExperiments performed with 2 cyclone stages and 2 filter stages in off-gas clean-up system.

$\mathrm{d}_{\text {Trace }}(<0.1 \mathrm{mg})$. 
APPENDIX E. TRACE-ELEMENT ANALYTICAL PROCEDURES 


\section{APPENDIX E. TRACE-ELEMENT ANALYTICAL PROCEDURES}

\section{First-Priority Elements}

Mercury, Solids. For solid samples (coal, fly ash, additive, etc.) approximately 0.1 to $1 \mathrm{~g}$ of well-ground material is used. The sample is placed in a quartz boat in a quartz tube and is combusted at $600-700^{\circ} \mathrm{C}$ in a pure oxygen stream flowing at a rate of $280 \mathrm{ml} / \mathrm{min}$. The combustion gases containing the mercury vapor are passed through an absorbent train consisting of two tubes, each of which contains $12.5 \mathrm{ml}$ of a $4 \% \mathrm{w} / \mathrm{v}$ solution of $\mathrm{KMnO}_{4}, 14 \mathrm{ml}$ of $1: 4 \mathrm{H}_{2} \mathrm{SO}_{4}$, and $23.5 \mathrm{ml}$ of water. After combustion is complete (15-20 min), the absorbent solution is decolorized with $10 \%$ hydroxylamine hydrochloride dropwise (no excess) and made up to a final volume with water. This volume may be as large as 1 liter depending on the anticipated mercury concentration. An aliquot is then transferred to an aeration bottle and $2 \mathrm{ml}$ of stannous chloride is added just prior to the analysis to reduce mercury to the metallic state. (The stannous chloride solution is prepared by dissolving $20 \mathrm{~g}$ of $\mathrm{SnCl}_{2}$ in $40 \mathrm{ml} \mathrm{HCl}$ and diluting this solution to $250 \mathrm{ml}$ with water.) The solution is then aerated, and the air stream containing the mercury is passed through a $10-\mathrm{cm}$ absorption cell where the mercury is measured by cold vapor atomic absorption at the $253.7 \mathrm{nM}$ wavelength. The instrument can be used to measure mercury in the range of 0.05 to $0.4 \mu \mathrm{g}$. Analyses are done at least in triplicate because experience has indicated that the distribution of mercury may be somewhat heterogeneous.

Mercury, Gold Coil. Mercury which has been amalgamated on the gold coil is released by heating in a quartz tube to $700^{\circ} \mathrm{C}$ within an $\mathrm{O}_{2}$ or inert gas purge stream. The mercury vapor is then treated as indicated in the above procedure.

Mercury, Sululious. Fur lodine monochloride solutions a suitable allquor is tränsferred to a small beaker, $5 \mathrm{ml}$ of $1 \mathrm{M} \mathrm{NaOH}$ is added, and the solution is mixed well. This is then transferred to the $10-\mathrm{cm}$ cold-vapor cell of the atomic absorption unit and diluted to $45 \mathrm{ml}$ with water. Five milliliters of reducing agent (1.2 $\mathrm{g}$ of hydroxylamine sulfate and $12 \mathrm{~g}$ of sodium chloride diluted to $100 \mathrm{ml}$ w1th wacer) is then added and the analysis is performed in the same way as indicated for solid samples.

For sodium carbonate solutions, $10 \mathrm{ml}$ of solution is transferred to a small beaker, and $\mathrm{KMnO}_{4}$ is added until a pink color is retained. The solution is then diluted with water at least twofold and made acidic (to $\mathrm{pH}<6$ ) with sulfuric acid prior to taking $50 \mathrm{ml}$ and transferring it to the atomic absorption unit. The instrumental procedure used is the same as that outlined above.

Fluoride, Coal. To determine fluoride in coal, 0.8 to $1 \mathrm{~g}$ of sample and $5 \mathrm{ml}$ of $1 \mathrm{M} \mathrm{NaOH}$ are placed in a Paar Bomb. Combustion requires $\sim 1 / 2 \mathrm{hr}$ in pure oxygen. After cooling, the contacted bomb 
surfaces are rinsed with water and the solution is quantitatively transferred to a beaker and diluted to $\sim 40 \mathrm{ml}$ with water. The $\mathrm{pH}$ is then adjusted to 5.2 with dilute $(0.25 \mathrm{M}) \mathrm{H}_{2} \mathrm{SO}_{4}$ and heated over a hotwater bath for approximately $10 \mathrm{~min}$. On cooling, $5 \mathrm{ml}$ of acetate buffer $\left(294 \mathrm{~g}\right.$ sodium citrate and $20.2 \mathrm{~g} \mathrm{KNO}_{3}$ adjusted to $\mathrm{pH} 6$ with citric acid) is added and the sample diluted to $50 \mathrm{ml}$. Instrumental analyses are performed using the fluoride specific ion electrode (S.I.E.) and standards prepared in acetate buffer solutions.

Fluoride, Non-Coal Solid. The determination of fluoride in samples from the combustor bed, cyclone, and filter is being done currently by a two-step leaching procedure followed by analysis of solutions with the S.I.E. In this procedure, $\sim 100 \mathrm{ml}$ of a. $25 \%$ by volume solution of TISAB (Orion total ionic strength adjustment buffer) in water is added to 1 to $2 \mathrm{~g}$ of sample. After the residue is allowed to settle, it is separated from the supernatant liquid, washed thoroughly, and transferred to a platinum crucible, where it is airdried. The dried residue is mixed with $2 \mathrm{~g}$ of Eschk's mixture (2:1 $\mathrm{MgO} / \mathrm{Na}_{2} \mathrm{CO}_{3}$ ), covered with an additional $1 \mathrm{~g}$ of mixture, and heated at $900^{\circ} \mathrm{C}$ for $35 \mathrm{~min}$. When cool, the mixture is leached with fresh TISAB solution. Fluoride analyses of all solutions, either combined or on an individual basis, are done using the S.I.E.

Another procedure which will be explored involves the separation of the fluoride from samples by a pyrohydrolysis technique, followed by determination in aqueous medium using the S.I.E. In this procedure, a sample of known weight would be mixed with a suitable chemical accelerator and heated to $2900^{\circ} \mathrm{C}$ in steam and oxygen. The volatilized fluoride silicates would be collected in an aqueous catch solution for S.I.E. analysis.

Fluoride, Solutions. Fluoride analysis on sodium carbonate solutions are performed by first diluting with the Orion TISAB solution followed by a S.I.E. determination. Depending on the concentration of fluoride anticipated, $75 \mathrm{ml}$ of sample or sample plus water is taken to a 100-ml final volume with TISAB. The S.I.E. determination on this solution is compared with standards prepared in the TISAB solution.

Lead. A well-ground coal sample of $\sim 1 \mathrm{~g}$ is placed in a platinum crucible and ashed overnight at $450^{\circ} \mathrm{C}$. (Non-coal samples are not ashed.) The ash or starting sample is then treated with $4 \mathrm{ml}$ of $50 \% \mathrm{HNO}_{3}$ (or $10 \mathrm{ml}$ for samples of additive), evaporated to approximately one-half the original volume, and filtered through Whatman 42 filter paper. An atomic absorption determination is performed at $217 \mathrm{nM}$ and compared with standards in a similar matrix. The optimum concentration for atomization is 0.1 to $1 \mu \mathrm{g} / \mathrm{ml}$.

Beryllium. Coal samples are ashed at $450^{\circ} \mathrm{C}$ overnight and then transferred to a $250 \mathrm{ml}$ Erlenmeyer flask. (Non-coal samples are not ashed.) Heat is applied with caution to be sure to retain any aerosols formed while $\mathrm{SO}_{3}=$ fumes are allowed to escape. One to two $\mathrm{ml}$ of hydrogen 
peroxide is added to oxidize organic materials present and heating is continued until reaction ceases. (This is apparent by the cessation of bubbling.) Three grams of anhydrous sodium sulfate is added and heating is continued on a hot plate for approximately 15 min to volatilize excess acid and ensure the formation of pyrosulfates. The solution is then heated over a Meeker burner (by hand) until the vigorous reaction subsides (3-4 min) and no additional fumes form. The flask is allowed to cool, $20 \mathrm{ml}$ of water is added, and heat is applied to dissolve the solid melt formed. Silicates are then removed by filtration, washed with hot water, and all solutions combined and taken to a $50 \mathrm{ml}$ final volume. A pH adjustment is made and the Be concentration of the solution is determined by fluorescence spectroscopy using a Beckman DU spectrophotometer.

\section{Second- and Third-Priority Elements}

Elements of second and third priority are determined by neutron activation analysis, a nuclear technique in which the elements to be analyzed are made radioactive by irradiation with neutrons. The gamma rays produced by the induced radioactive species are then measured and identified. The radioactivity of a particular neutron activation product is directly proportional to the concentration of its parent 1sotope. The basic equation for neutron activation is

$$
\lambda N=\operatorname{no\phi }\left(1-e^{-\lambda t}\right)
$$

where

$$
\begin{aligned}
& \lambda=\text { decay constant of the radioactive species, in } \mathrm{sec}^{-1} \\
& \mathrm{~N}=\text { atoms of the radioactive species } \\
& \mathrm{n}=\text { atoms of the target material } \\
& \sigma=\text { Llie activation cross section for the nuclear } \\
& \quad \text { reaction, } 1 \mathrm{n} \mathrm{cm}^{2} \\
& \psi=\text { ueutron flux, in } \mathrm{n} / \mathrm{cm}^{2}-\mathrm{sec} \\
& t=\text { irradiation time, in sec }
\end{aligned}
$$

By using a suitable flux monitor and a detertor nf known counting efficiency, the concentration of an element in a sample can be calculated by means of the above equation. fundamentally, the steps in a typical analysis are as follows:

1. Irradiate weighed quantities of the sample ( $100 \mathrm{mg})$ and a flux monitor in suitable containers for a sufficient time to produce adequate radioactivity for the element of interest.

2. After irradiation, the analysis is facilitated by gamma. counting the samples and flux monitor on an absolutely calibrated $\mathrm{Ge}(\mathrm{L} i$ ) detector at optimum times to directly measure radioactive species with short, intermediate, and long half-lives. To ensure proper identification of the species being measured, the half-life, and, where possible, secondary associated gamma-rays are checked at convenient time intervals. 
The samples and flux monitors are irradiated in Argonne's "CP-5" reactor in either the "isotope tray" or the "rabbit" facility where the thermal neutron flux available is about $1.5 \times 10^{12}$ to $5 \times 10^{13}$ $\mathrm{n} /\left(\mathrm{cm}^{2}\right)(\mathrm{sec})$. The samples are irradiated to a fluence of about $1 \times 10^{17} \mathrm{n} / \mathrm{cm}^{2}$. The Ge(Li) detector used for counting is coupled to a 4096-channel analyzer system. The detector is a coaxial-type Ge(Li) having a full width half maximum (FWHM) of $2.0 \mathrm{keV}$ for the $1.33-\mathrm{MeV}$ gamma ray of ${ }^{60} \mathrm{Co}$ and a peak-to-Compton ratio of about $30: 1$. The data readout from the analyzer system is in the form of magnetic tape compatible with the IBM $370 / 195$ computer system which is used for analysis of the pulse-height spectra.

The neutron activation procedure is currently being developed. 
APPENDIX F. CONVERSION FACTORS, ENGLISH TO METRIC UNITS 
TABLE F-1. TABLE OF CONVERSION FACTORS, ENGLISH TO METRIC UNITS

\section{English Unit}

Length

Area

Volume

Mass

Pressure

Temperature

Energy

V̀elocity

Flow

Heat-Transfer Coefficient in

$\mathrm{ft}$

$\ln ^{2}$

$f t^{2}$

in $^{3}$

$f t^{3}$

$1 b$

atm

psi.

${ }^{\circ} \mathrm{F}$

${ }^{\circ} \mathrm{R}$

BTU

$\mathrm{ft} / \mathrm{sec}$

cfm

$\mathrm{Btu} /(\mathrm{hr})\left(\mathrm{ft}^{2}\right)\left({ }^{\circ} \mathrm{F}\right)$
Metric Equivalent

$2.54 \mathrm{~cm}$

$0.305 \mathrm{~m}$

$6.45 \mathrm{~cm}^{2}$

$0.0929 \mathrm{~m}^{2}$

$16.4 \mathrm{~cm}^{3}$ $.0283 \mathrm{~m}^{3}$

$453.6 \mathrm{~g}$

$760.0 \mathrm{mmHg}$

51.7. $\mathrm{mm} \mathrm{Hg}$

$1.8\left({ }^{\circ} \mathrm{C}\right)+32$

$1.8^{\circ} \mathrm{K}$

$252 \mathrm{Cal}$

$30.48 \mathrm{~cm} / \mathrm{sec}$

$0.4721 / \mathrm{sec}$

$5.68 \mathrm{~W} /\left(\mathrm{m}^{2}\right)(\mathrm{C})$ 